НАЦИОНАЛЬНЫЙ ИССЛЕДОВАТЕЛЬСКИЙ ИНСТИТУТ

МИРОВОЙ ЭКОНОМИКИ И МЕЖДУНАРОДНЫХ ОТНОШЕНИЙ ИМЕНИ Е.М. ПРИМАКОВА

РОССИЙСКОЙ АКАДЕМИИ НАУК

\title{
М.В. Стрежнева
}

\section{ЭКОНОМИЧЕСКИЙ И ВАЛЮТНЫЙ СОЮЗ В ЕВРОПЕ:} проблемы эффективности и легитимности

Москва

ИМЭМО РАН

2018 
УДК 339.9(4)

ББК 65.6(4)

Стре 84

Серия «Библиотека Национального исследовательского института мировой экономики и международных отношений имени Е.М. Примакова»

Рецензенты:

доктор экономических наук, профессор С.Л. Ткаченко кандидат экономических наук А.Н. Цибулина

Стре 84

Стрежнева М.В. Экономический и валютный союз в Европе: проблемы эффективности и легитимности. - М.: ИМЭМО РАН, 2018. - 150 с.

ISBN 978-5-9535-0543-7

DOI: $10.20542 / 978-5-9535-0543-7$

Монография посвящена исследованию системы управления Экономическим и валютным союзом (ЭВС) в интегрированной Европе. Оцениваются её соответствие требованиям демократической легитимности и эффективность политики, которая проводится в институциональных рамках ЭВС. Наряду с особенностями наднациональной кредитноденежной политики и углублением в еврозоне макроэкономической координации, рассмотрены политико-организационные аспекты в строительстве Банковского союза, а также состояние и вероятные перспективы фискальной интеграции в ЕС.

Strezhneva M.V. Economic and Monetary Union in Europe: the problems of Effectiveness and Legitimacy. - Moscow, IMEMO, 2018. 150 p.

ISBN 978-5-9535-0543-7

\section{DOI:10.20542/978-5-9535-0543-7}

This is a research of the governance system in the European Economic and Monetary Union (EMU). Its conformity to the requirements of democratic legitimacy and the effective strength of the policy, conducted in the institutional framework of the EMU, are analysed. Along with special features of the supranational monetary policy and enhanced macroeconomic coordination in the Eurozone, particular attention is being paid to political and organizational aspects of the Banking Union, and to the issue of fiscal integration.

В оформлении использована работа художника Л.Ш. Ора Сиккама

(Louis Charles Hora Siccaта - Рейксмузеум, Амстердам, Нидерланды)

\section{Публикации ИМЭМО РАН размещаются на сайте https://www.imemo.ru}

ISBN 978-5-9535-0543-7

(C) ИМЭМО РАН, 2018

(C) Стрежнева М.B., 2018 


\section{СОДЕРЖАНИЕ}

СПИСОК СОКРАЩЕНИЙ 4

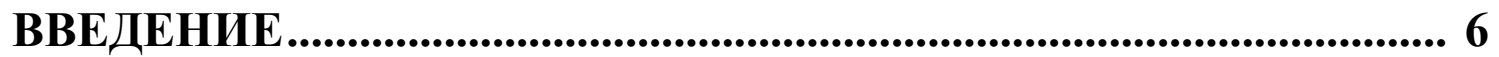

ГЛАВа 1. МНОГОУРОВНЕВАЯ СИСТЕМА, СУБСИДИАРНОСТЬ И ЛЕГИТИМНОСТЬ ...................... 16

Глава 2. ВАЛЮТНЫЙ СОЮЗ........................................................ 45

Глава 3. БАНКОВСКИЙ СОЮЗ ....................................................... 74

ГЛава 4. ОБЩАЯ ЭКОНОМИЧЕСКАЯ ПОЛИТИКА. ФИСКАЛЬНЫЙ СОЮЗ ........................................................ 95

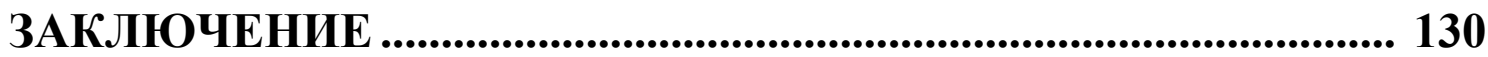

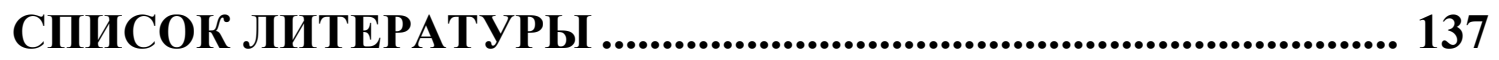




\section{СПИСОК СОКРАЩЕНИЙ}

БС Банковский союз

ВВП валовый внутренний продукт

ВНД валовый национальный доход

ДФЕС Договор о функционировании Европейского союза

ДЭС Договор о Европейском союзе

EACT Европейская ассоциация свободной торговли

ЕБВ Европейское банковское ведомство

EBP Единый внутренний рынок

EBC Европейская валютная система

EEA Единый европейский акт

ЕИБ Европейский инвестиционный банк

ЕК Европейская комиссия

EMH Единый механизм по банковскому надзору

EMC Европейский механизм стабильности

ЕМСБ Единый механизм по санации банков

ЕП Европейский парламент

EC Европейский союз

ECCP Европейский совет по оценке системных рисков

ЕСФО Единый совет по финансовому оздоровлению

ЕСЦБ Европейская система центральных банков

ЕФС Единый фонд санации

ЕФСИ Европейский фонд стратегических инвестиций

ЕЦБ Европейский центральный банк 
ЕЭС Европейское экономическое сообщество

ИНЭП интегрированные на уровне ЕС направления национальной экономической политики

МВФ Международный валютный фонд

НПР национальная программа реформирования

НЦБ национальный центральный банк

OB3 оптимальная валютная зона

ПСР Пакт стабильности и роста

ССЦ среднесрочная цель по бюджету в рамках превентивной части ПСР

CУ Совет управляющих Европейского центрального банка

ФРС Федеральная резервная система Соединённых Штатов Америки

ЭВС Экономический и валютный союз

ЭКОФИН

Совет министров экономики и финансов ЕС

ЭКЮ европейская расчётная единица (до введения евро) 


\section{ВВЕДЕНИЕ}

По итогам 2017 г. в Европейском союзе был зафиксирован экономический рост, составивший $2,5 \%$ (2,4\% для еврозоны), что явилось наилучшим показателем за целое десятилетие. Сразу зазвучали обнадёживающие прогнозы и на дальнейшую перспективу, которые впоследствии пришлось скорректировать в сторону некоторого понижения (рост до 2,1\% для еврозоны на 2018 год) ${ }^{1}$. Среди ключевых индикаторов состояния экономики в регионе продолжает отставать в росте главным образом уровень заработной платы. Но нельзя полностью исключить и опасность соскальзывания в новый кризис. При этом некоторым частям экономики ЕС угрожает перегрев (темпы роста превышают её долгосрочный потенциал). Безработица сократилась в целом до 8\% (при уровне в 15\% в Испании и Греции и около $10 \%$ во Франции). Одновременно с тем в интегрированной Европе наблюдается дефицит квалифицированной рабочей силы ${ }^{2}$. Промышленность еврозоны традиционно находится в сильной зависимости от внешнего спроса, а потому особенно уязвима для риска перебоев в международной торговле. В данном отношении основанием для беспокойства в Брюсселе может служить сохраняющаяся вероятность торговой войны между ЕС и Соединёнными Штатами ${ }^{3}$.

Три серьёзнейших внутренних политических риска для ЕС в настоящее время - это Брексит, т.е. предстоящий выход из Союза Великобритании; каталонский кризис 2017 г. в Испании, где нельзя исключить новых вспышек сепаратистской активности; и положение дел в Италии (там электоральные успехи популистских и евроскептических партий, «Лиги (Севера)» и «Движения "5 звезд"», позволили им в 2018 г. сформировать национальное правительство во главе с «технократом» Джузеппе Конте, которое, вопреки рекомендациям Европейской комиссии, тут же вознамерилось нарастить в 2019 г. уже согласованный прежним правительством с европейскими инстанциями дефицит национального бюджета). Глубочайшие негативные политические последствия в ЕС может принести и ситуация с беженцами ${ }^{4}$.

В том числе и из-за кризиса в Каталонии и его последствий, Испании, как ожидается, не удастся выполнить свои обязательства по исправлению ситуации с национальным бюджетом ранее 2035 г. (снизив государственный долг до требуемых по европейским правилам 60\%). Обремененная долгами Италия, высокий уровень государственного долга в

\footnotetext{
${ }^{1}$ European Economic Forecast. Summer 2018 (interim). URL: https://ec.europa.eu/info/sites/info/files/economyinance/ip084_en.pdf. См. также: EU economic growth forecast reduced. URL: https://www.dw.com/en/eu-economicgrowth-forecast-reduced/a-44649654.

${ }^{2}$ В период экономического спада и роста безработицы, начиная с 2008 г., такой дефицит перестал быть существенным фактором в Европе, но после 2012 г. данная проблема вернулась и даже стала ещё острее, чем в докризисный годы, в особенности в странах Центральной, Восточной и Северо-Восточной Европы. См.: Batsaikhan Uuriintuya, Darvas Zsolt and Gonçalves Raposo Inês (2018) People on the move: migration and mobility in the European Union // Bruegel Blueprint Series, Vol. XXVIII, Brussels, Belgium: Bruegel, pp. 63-64. URL: http://bruegel.org/wp-content/uploads/2018/01/People_on_the_move_ONLINE.pdf.

3 Erlanger Steven (July 26, 2018) Europe Averts a Trade War with Trump. But Can It Trust Him? URL: https:/www.nytimes.com/2018/07/26/world/europe/donald-trump-us-eu-trade.html.

${ }^{4}$ Особенно острый кризис с беженцами-иммигрантами разразился в ЕС летом 2015 г., когда сотни тысяч людей с Ближнего Востока и из стран Африки пытались пересечь Средиземное море. Миграционное давление на Европу, вызывающее политические разногласия между странами ЕС и внутри отдельных европейских стран, выросло вследствие войны в Сирии и событий арабской весны. См.: Hollifield J.F. (2016) The Refugee 'Crisis' in Europe and the Policy Responses // Policy Brief (Washington, DC: Woodrow Wilson Center), pp. 1-3.
} 
Португалии и в Республике Кипр тоже остаются предметом озабоченности для официального Брюсселя, как и экономическое состояние многострадальной Греции. Таким образом, несмотря на наметившиеся успехи, Европейский союз пребывает не в лучшем состоянии, что, в частности, повышает требования и внимание к устройству Экономического и валютного союза (ЭВС), система управления которым чрезвычайно сложна и запутанна (общая схема управления в ЭВС в графическом виде представлена на следующей странице).

Экономический и валютный союз - это продвинутая стадия региональной европейской интеграции, включающая, прежде всего, единую кредитно-денежную политику и тесно скоординированную экономическую политику для стран, которые перешли на евро. ЭВС, возникнув в 1990-е годы, опирается на созданный в предшествующие десятилетия общий рынок товаров и услуг и, в свою очередь, необходим для полноценной работы Единого внутреннего рынка ЕС, так как колебания обменного курса валют государств-членов могут стать дополнительной помехой для развития внутрирегиональной торговли и инвестиций. Принципиальное решение перейти на единую валюту, в случае его реализации, непременно влечёт за собой и выгоды, и издержки для отдельных стран, а хорошо работающий внутренний рынок способен сокращать последние.

Имея единую валюту, государства-члены интеграционного объединения лишены возможности реагировать на происходящее в их экономиках поодиночке, меняя процентные ставки или курсовую стоимость своей валюты. Но единый рынок может в принципе снизить потребность в подобных гипотетических независимых действиях, если он обеспечивает выравнивание деловых циклов в странах-участницах. Когда они вместе переживают подъёмы и спады, это создаёт наилучшие условия для централизованной на наднациональном уровне кредитно-денежной политики. Однако проблема с ЕС заключается в том, что здесь такого выравнивания не происходит. Сложившийся ЕВР сам по себе в некоторых отношениях несовершенен - он остаётся сегментированным и, к примеру, до сих пор затрагивает сферу услуг лишь частично.

В свою очередь, Экономический и валютный союз в ЕС был построен в 1990-е годы в отсутствие политического союза, при управлении государственными финансами странучастниц по далеко не бесспорным европейским правилам и с социальной политикой, которой, по большому счету, была отведена незавидная роль амортизатора экономических шоков. Никак нельзя утверждать, что именно к подобному результату стремились отцыоснователи - авторы европейского интеграционного проекта.

В ходе долгих лет развития европейской интеграции её характер несколько раз серьёзно менялся. В начале пути, начиная с 1950-х годов, речь шла главным образом о строительстве общего рынка, подчинённого принципам свободы и справедливости. На общем рынке ведущая роль в его регулировании должна была быть передана европейским институтам, обеспечивающим гармонизацию действующих правил. Но такая схема не сработала, и созданные в объединении институты не справились с поставленной задачей, что наглядно показал первый серьёзный кризис в интеграционном развитии, случившийся в 1970-е годы. Тогда Суд ЕС в сотрудничестве с Комиссией, а впоследствии и при поддержке государствчленов, взял инициативу в дальнейшем продвижении интеграции на себя. Результатом соответствующих усилий стало создание единого рынка, который был в меньшей степени основан на гармонизации и выравнивании правил для всех и в большей мере - на национальном контроле и рыночной конкуренции.

В начале 1970-х годов шестёрка членов тогдашнего Европейского экономического союза уже попыталась создать ЭВС, но тогда такая попытка провалилась. Если вспомнить сегодня детали оставшегося не реализованным «плана Вернера», содержавшего программу построения 
экономического и валютного союза, каким он виделся европейской элите в 1970 -е годы ${ }^{5}$, то мы увидим принципиально иную картину, нежели та, что впоследствии сложилась в реальности. В «плане Вернера» валютный союз представал третьим и завершающим этапом в строительстве ЭВС, следующим уже после успешной политической и социальной интеграции, а не строился в отрыве от неё. Иными словами, сближение экономических и социальных показателей на интеграционном пространстве, преодоление его гетерогенности тогда выступало для валютного союза в качестве необходимого предварительного условия.

У этого провала были как внешние (развал Бреттон-Вудской системы фиксированных курсов), так и внутренние (незавершённость строительства общего рынка в Западной Европе

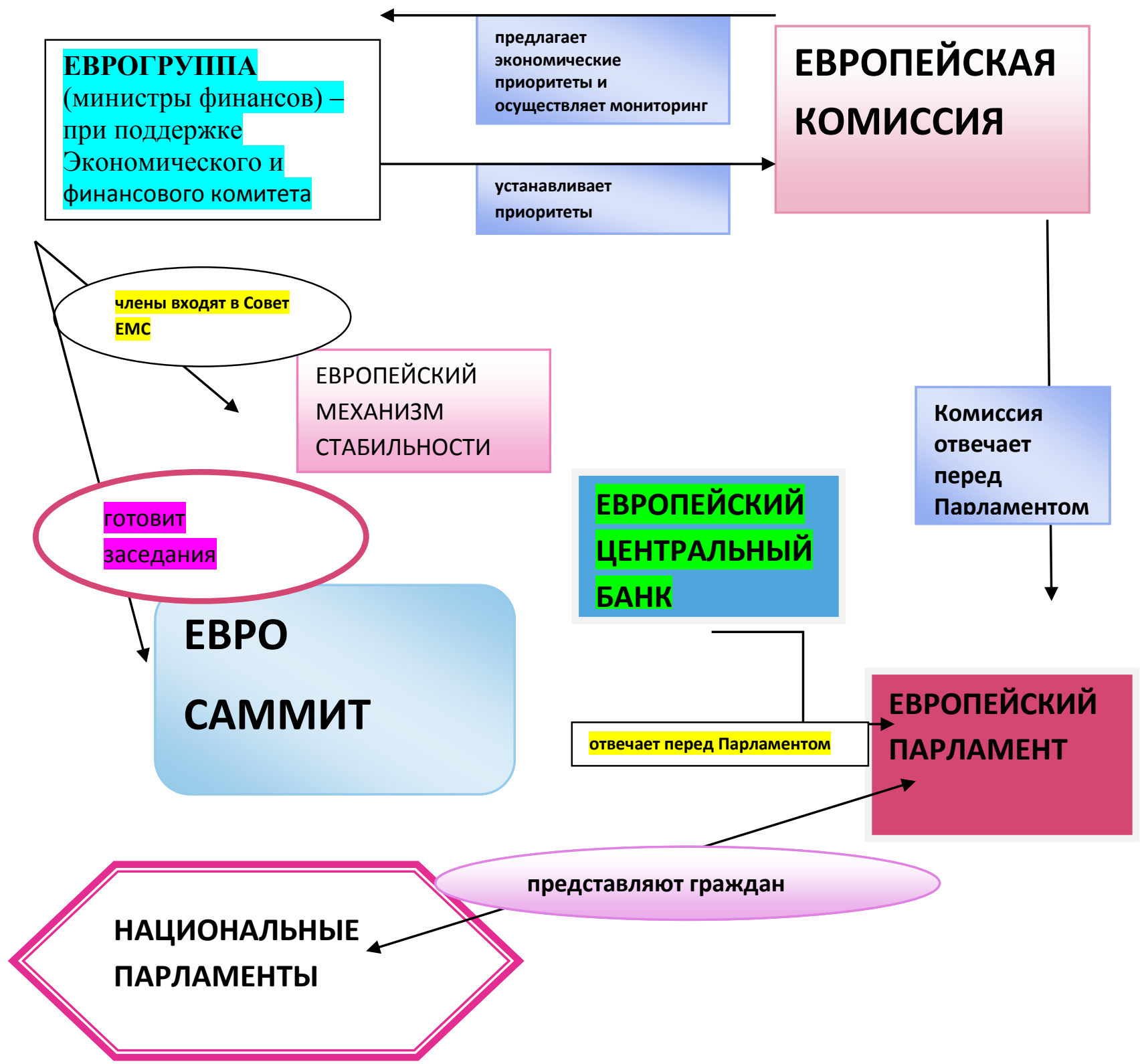

Схема 1. Управление Экономическим и валютным союзом

Источник: Европейская комиссия

\footnotetext{
${ }^{5}$ Werner Report. Report to the Council and the Commission on the realization by stages of Economic and Monetary Union in the Community. Supplement to Bulletin $11-1970$ of the European Communities. http://aei.pitt.edu/1002/1/monetary_werner_final.pdf.
} 
на тот момент) причины. Однако он принёс европейской шестёрке ценный опыт. Государства - члены Европейского экономического сообщества осознали, что в процессе региональной интеграции не следует забегать вперёд, но нужно сначала достроить общий рынок до состояния единого внутреннего рынка, договориться о нескольких сопровождающих его общих политиках и только потом связывать себя договорными обязательствами, касающимися возведения тяжеловесной конструкции ЭВС.

Договорную основу ЭВС составил в итоге Маастрихтский договор 1992 г. В Маастрихтском договоре нашла отражение иная концепция, нежели та, что была упомянута выше: критерии конвергенции касательно госдолга и дефицита государственного бюджета теперь призваны были послужить необходимым инструментом, побуждающим экономики стран-участниц валютного союза к дальнейшей экономической интеграции, для успеха которой, в свою очередь, считалась необходимой интеграция социальная и политическая. Последней нужно было добиваться сознательно - с использованием структурных фондов, наращиванием общего бюджета и принятием Европейской конституции. Амстердамский договор 1997 г. и Европейская стратегия занятости, им инициированная, а также Лиссабонская стратегия и развитие Открытого метода координации $(\mathrm{OMK})^{6}$ в приложении к сферам занятости, борьбы с бедностью и пенсионного обеспечения, «работали» на такую перспективу.

Однако провал Европейской конституции на референдумах во Франции и Нидерландах в 2005 г. в очередной раз прервал поступательное развитие в намеченном направлении. Кроме того, уже в 2004 г. Группа высокого уровня во главе с Вимом Коком (Wim Kok -премьерминистр Голландии с 1994 по 2002 гг.) пришла к выводу, что метод ОМК, который был избран для реализации Лиссабонской стратегии, не оправдал возлагавшихся на него надежд. В докладе, в частности, утверждалось, что Евросоюз упустил возможность реформирования экономики, уступив в конкурентной гонке США и развивающимся экономикам Азии. ОМК был признан малоэффективным, а главной причиной провала, по мнению Кока, стало то, что у Европейской комиссии не оказалось достаточных наднациональных полномочий для внедрения Лиссабонской повестки ${ }^{7}$.

В последующем возобладало третье видение ЭВС: если искомый валютный союз требует форсировать строительство экономического союза, то политический союз в среднесрочной перспективе скорее недоступен или даже нежелателен, поскольку к валютной политике должны быть причастны главным образом эксперты, которые в ней разбираются, а не парламентарии. В 2004-2005 гг,, особенно после того, как португалец Жозе Мануэл Баррозу возглавил Европейскую комиссию, от упора на ОМК отказались, и на передний план в политике и в европейском дискурсе, в качестве высшего приоритета, вышло именно поддержание жизнеспособности валютного союза, которую отстаивает, прежде всего, Европейский центральный банк.

Инструментами финансовой стабилизации (на случай неизбежных кризисных потрясений) теперь были избраны дерегулирование в области социальной политики национального уровня, стимулирование трансъевропейской мобильности рабочей силы и политическое управление средствами обеспечения соблюдения - под угрозой санкций -

\footnotetext{
${ }^{6}$ В рамках Открытого метода координации национальные власти должны координировать свои действия на основании европейских указаний и под наблюдением европейских институтов, но вне сферы наднационального регулирование и в отсутствие обязывающих соглашений. Данный метод может быть использован, когда для принятия базовых актов ЕС нет достаточной правовой основы (в качестве примера укажем транснациональную координацию национальных образовательных систем).

${ }^{7}$ Report from the High Level Group chaired by Wim Kok. Facing the Challenge: The Lisbon Strategy for Growth and Employment. $\quad$ November 2004. https:/ec.europa.eu/research/evaluations/pdf/archive/fp6-evidencebase/evaluation_studies_and_reports/evaluation_studies_and_reports_2004/the_lisbon_strategy_for_growth_and_empl oyment_report_from_the_high_level_group.pdf
} 
процедур и формальных правил (европейский семестр, бюджетная дисциплина), якобы не допускающих политических разночтений. Однако сомнительно, чтобы европейский интеграционный проект можно было реализовать через отказ от того, что составляет существо европейской социальной модели. В конце пути с неизбежностью встает политический вопрос о целесообразности подобного валютного союза (в котором цель интеграционного развития и его средства поменялись местами). Отсюда - активное обсуждение будущего ЕС, ревизионистские предложения и планы по внедрению определенных форм федерализма, которые будут рассматриваться и анализироваться на страницах этой книги (банковский союз, бюджетная интеграция, более глубокая экономическая интеграция), и, наконец, идея «европейского правительства».

Прошедшие мировой экономический кризис 2008-2009 гг. и финансовый кризис в еврозоне, за ним последовавший, со всей наглядностью продемонстрировали, сколь тесно взаимосвязаны участвующие в ней страны. В конечном счёте, более сильные страны еврозоны и европейские институты не смогли позволить странам более слабым самостоятельно пойти ко дну, отказав им в поддержке в самый острый момент, но, напротив, были вынуждены предложить последним разные меры спасения. В еврозоне проблемы, возникшие в одной стране, могут быстро распространяться и на другие страны. Если под вопросом состояние банковской системы в одной стране, то международные рынки начинают выказывать недоверие и к кредитным институтам других стран. Когда возникает опасность выхода из еврозоны какого-то из её членов, это неизменно негативно сказывается и на имидже евро в целом.

В широком плане, во время кризиса обнаружилось, что отношения между государствами-членами и их банками в Европе глубоко неблагополучны. При возникновении проблем со своими банками государствам приходилось заниматься их спасением. Это вело к наращиванию национального долга и порождало у инвесторов сомнения в финансовой устойчивости отдельных стран (таких, как Ирландия или Испания), усугубляя проблемы тех же национальных банков, зачастую являющихся держателями государственных ценных бумаг. Таким образом, модель единого рынка, при которой, как в ЕС до кризиса, банки и фирмы, предоставляющие финансовые услуги, в основном регулировались и, в конечном счёте, получали поддержку от собственных стран, но осуществляли свою деятельность по всей Европе, оказалась нежизнеспособной. Мы наблюдаем также, как в некоторой степени утратили прежнюю действенность монетарные решения Европейского центрального банка. Например, снижение им процентных ставок может теперь и не отражаться в более низкой стоимости заёмных финансовых средств на местах.

Мировой кризис выявил необходимость изменения правил регулирования в Европе одной из наиболее важных отраслей в современной экономике - сферы финансовых услуг. Он спровоцировал попятное движение к фрагментации уже оформившегося к тому времени единого финансового рынка ЕС, так как компании в кризисных условиях стали возвращать на родину часть своей транснациональной деятельности, причём нередко это делалось по указанию национальных надзирающих органов. Иными словами, некоторые весьма значимые из ранее достигнутых результатов функционирования единого рынка в Европе оказались в результате утрачены. Условия конкуренции для фирм нефинансового профиля в отдельных странах стали больше разниться между собой, нежели раньше, поскольку доступность, как и стоимость привлечения капитала оказались неодинаковы. Однако позже заключенные в сложившейся модели единого рынка противоречия и необходимость в поддержании ЭВС стали подталкивать систему экономического управления в ЕС к большей централизации на европейском уровне...

Помимо координации национальных курсов экономической политики и независимой денежно-кредитной политики ЕЦБ, уже упомянутых выше, система управления ЭВС на сегодняшний день включает также координацию национальной бюджетной политики, 
банковский надзор в еврозоне, единую валюту и европейские управленческие механизмы и технологии. Но в рамках ЭВС по-прежнему отсутствует единый институт, который отвечал бы за европейскую экономическую политику в качестве полноценной исполнительной власти. Ответственность за неё делят между собой правительства государства-члены и несколько европейских институтов:

- Европейский совет, определяющий главные ориентиры экономического курса для интеграционного объединения в целом;

- Совет министров ЕС (Совет министров, Совет), координирующий национальные курсы и принимающий решение о переходе на евро отдельных стран;

- Еврогруппа, которая играет существенную фактическую роль в управлении экономикой в Еврозоне;

- государства-члены, которые принимают свои национальные бюджеты (в пределах европейских лимитов) и проводят структурную политику на собственных рынках труда, пенсий и капитала;

- Европейская комиссия (Комиссия, ЕК), которая осуществляет мониторинг выполнения принятых на наднациональном уровне решений и следит за соответствием национальных курсов установленным европейским требованиям;

- Европейский центральный банк (ЕЦБ), который ведёт наднациональную кредитноденежную политику и осуществляет надзор над кредитными институтами в Еврозоне;

- Европейский парламент (ЕП), который, совместно с Советом, принимает европейское законодательство и осуществляет демократический контроль над процессом экономического управления - прежде всего в форме Европейского диалога.

В большинстве случаев эксперты признают систему институтов ЭВС недостаточно эффективной и легитимной, чтобы обеспечивать продуктивное использование имеющихся у Европы грандиозных хозяйственных ресурсов, благоприятствовать созданию в достаточном количестве новых рабочих мест и убедительно поддерживать социальную справедливость ${ }^{8}$. Проблема эффективности, подобным образом поставленная, затрагивает не только институциональное устройство ЭВС, в котором в кризисные годы выявились серьёзные пробелы. Она также касается и политики, которая проводится в его рамках 9 .

Впрочем, важным шагом на пути совершенствования Экономического и валютного союза в Европе в 2010-е годы стал Банковский союз, обеспечивающий последовательное применение банковских правил ЕС в странах-участницах. В Банковском союзе два основных элемента. Это, во-первых, наднациональный надзор над всеми крупными европейскими банками и, во-вторых, единообразная и последовательная практика кризисного управления, которая может быть задействована по отношению к крупным и трансграничным европейским банкам.

Чтобы обеспечить успех единой валюты, которая тяжело пережила прошедший финансовый кризис в Европе, в дальнейших изменениях нуждается действующая модель ЕВР. Проблемы в еврозоне, начавшиеся в 2008 г., продемонстрировали как тесную связь между Единым внутренним рынком и ЭВС, так и нестыковки между ними (начиная с несовпадения территориальных границ между ЕВР и еврозоной). Для национальных правительств принципы внутреннего рынка порождают, по крайней мере, два осложнения. С одной стороны, население государств-членов ожидает, что собственное правительство обеспечит его защиту от деградации окружающей среды, некачественных продуктов и тому подобных рисков. При

\footnotetext{
${ }^{8}$ Sims C. A. (2012) Gaps in the Institutional Structure of the Euro Area // Banque de France, Financial Stability Review, No. 16 (April), pp. 1-7.

${ }^{9}$ Obstfeld M. (2013) Finance at center stage: Some lessons of the euro crisis // European Economy Economic Papers, No. 493, Brussels: European Commission; Beker V. and Moro B. (eds.) (2016) The European Crisis, Bristol, UK: World Economic Association Books Conference Series.
} 
возникновении проблемы (скажем, скандала, связанного с попаданием в торговую сеть некачественных продовольственных товаров) в ней могут обвинить именно национальное правительство. Но на деле правительства в ЕС отказались от способности в полной мере контролировать товары, которые продаются в их стране. Таким образом, им порой приходится расплачиваться и за то, на что они не могут повлиять. С другой стороны, вытекающая из функционирования ЕВР повышенная конкуренция национальных и зарубежных товаров и услуг может восприниматься кем-то как несправедливая.

Национальные фирмы, которые проигрывают в такой конкурентной борьбе, зачастую винят в собственной неудаче различные дискриминационные, по их оценке, регуляторные преимущества, которыми пользуются в условиях ЕВР их иностранные конкуренты (такие преимущества, как более низкие национальные уровни заработной платы, например), и требуют национальной защиты. Но такая защита по действующим европейским правилам в большинстве случаев является незаконной.

Произведенные перемены в европейском экономическом управлении, о которых пойдёт речь в этой публикации, допустимо было бы счесть успешными, если бы они помогали справиться с кризисом в кратковременной перспективе или убедительным образом снижали вероятность кризиса в долговременном плане, в чём ни у кого нет сейчас большой уверенности. Вместе с тем реформы, уже осуществлённые в ответ на многочисленные вызовы, с которыми ЕС и еврозона сталкивались, начиная с 2008 г., заметным образом трансформировали европейское управление, поставив перед исследовательским сообществом непростую задачу - проанализировать и оценить уже произошедшую неоднозначную трансформацию.

При всех высказываемых претензиях к изменениям в устройстве ЭВС, которые произошли за кризисный период, их ни в коем случае не следует и недооценивать. Они включили меры по оказанию финансовой помощи государствам-членам, оказавшимся в затруднительном положении, укрепление системы наблюдения над национальной экономической и фискальной политикой и оформление нового режима для кредитных институтов (банков), действующих на Едином внутреннем рынке.

Уже проведенные перемены, тем не менее, не являются окончательными. Реформа ЭВС, как мы увидим по ходу дальнейшего рассказа, остаётся незавершённой и будет продолжена. Так называемые доклады председателей, а именно Доклад четырёх председателей, обнародованный в декабре 2012 г. $^{10}$, как и последовавший за ним Доклад пяти председателей (июнь 2015 г.) $)^{11}$, нарисовали долговременную картину переформатирования ЭВС, которую ещё предстоит воплощать в жизнь. Как считают в руководстве Европейского союза, переформатирование должно основываться на четырёх элементах: финансовом союзе, фискальном союзе, экономическом союзе и на преодолении демократического дефицита, т.е. неудовлетворительного соблюдения в практике европейского экономического управления принципов и критериев демократии.

С появлением ЭВС вошедшие в еврозону страны утратили непосредственный контроль над денежно-кредитной политикой, которая теперь проводится централизованно, на европейском уровне. Но национальная бюджетная политика сохранилась, и значимость её в кризисные годы даже заметно возросла, поскольку её стали рассматривать в интегрированной Европе как главный механизм по предотвращению экономических шоков на будущее или хотя бы смягчению их воздействия на сферу занятости и доходы населения. В то же время сложившаяся комбинация наднациональной кредитно-денежной политики и автономной

\footnotetext{
${ }^{10}$ Herman Van Rompuy et al., Towards a Genuine Economic and Monetary Union, 5 December 2012, http://www.consilium.europa.eu/uedocs/cms_Data/docs/pressdata/en/ec/134069.pdf.

${ }^{11}$ Jean-Claude Juncker et al., Completing Europe's Economic and Monetary Union, 22 June 2015, https://ec.europa.eu/priorities/publications/five-presidents-report-completing-europeseconomicand-monetary-union_en.
} 
национальной бюджетно-налоговой политики как таковая явно продемонстрировала свою неудачу. Другие потенциально возможные инструменты, включая (недостаточно мобильную в Европе) рабочую силу или (не отличающуюся повышенной гибкостью) заработную плату, предсказуемым образом тоже не сработали сколько-нибудь убедительно.

При этом если у большинства государств-членов ЕС, рассматриваемых по отдельности, сохраняются в принципе сильнодействующие бюджетные механизмы автоматической стабилизации экономики, позволяющие реагировать на экономические шоки, то у Европейского союза, взятого в целом, аналогичный инструмент вообще отсутствует. В уже упомянутом Докладе пяти президентов 2015 года идея учреждения общей бюджетной обеспеченности (common fiscal capacity) была выдвинута в качестве одного из шагов на пути к завершению ЭВС к 2025 году. Хотя никакого конкретного механизма достижения этого в Докладе предложено не было, в нём прозвучали четыре критерия, которым подобный стабилизатор должен отвечать. Он не должен приводить к постоянным трансфертам из одних стран еврозоны в другие, он не должен подрывать стимулы к ведению рациональной бюджетной политики в национальных рамках, он должен действовать в рамках всего ЕС(а не только еврозоны) и он не подменять собой инструменты экстренного кризисного управления.

Как бы то ни было, парадоксальным образом, под давлением недавних пертурбаций, на настоящем этапе произошла вовсе не дезинтеграция европейского ЭВС, а его дальнейшая специфическая интеграция. В настоящей работе незавершённая реформа ЭВС и её дальнейшие перспективы оцениваются с политологической точки зрения. В фокусе внимания - ускользающий баланс между эффективностью и легитимностью экономического управления. $\mathrm{C}$ теоретико-методологическом плане здесь избран институциональноорганизационный аналитический подход. Под институтами, согласно (нео)институционализму ${ }^{12}$, одновременно подразумеваются:

(a) автономные акторы (в данном случае национальные правительства и институты Европейского союза, начиная с Европейской комиссии и Европейского центрального банка), которые трактуются как агенты, заинтересованные в максимизации собственной власти и влияния в рамках европейского управления;

(б) правила, ограничительные установления, критерии и ориентиры, сообщающие структуру человеческим взаимоотношениям и взаимодействиям ${ }^{13}$.

С одной стороны, речь в данном случае идёт о роли и мере влияния европейских институтов (органов) при выполнении ими функций политического управления экономикой, ответственность за которое в Европейском союзе формально по преимуществу лежит на плечах национальных правительств. С другой стороны, при предметном анализе валютного, банковского и экономического союзов рассматриваются структурные ограничители поведения национальных правительств, являющиеся результатом европеизации национальных политических систем.

Под организациями здесь понимаются схемы действия, которые порождают определённые мотивационные структуры для людей, позиционирующих себя внутри того или иного европейского или национального института. Организационная структура всегда сказывается на том, как развиваются институты. Ведь многие институты придерживаются схожих норм и практик, тогда как их внутренние мотивационные структуры организованы поразному, что и ведёт к разнообразию в достигаемых результатах и в поведении акторов.

\footnotetext{
${ }^{12}$ Подробнее см.: Патрушев С. (2001) Институционализм в политической науке: этапы, течения, идеи, проблемы // Зарубежсная политология в XX столетии: Сб. науч. тр. / РАН ИНИОН. Отв. ред. вып. Ильин М.В. Москва, № 2, pp. 146-186. URL: http://pavroz.ru/files/patrushevinst.pdf.

${ }^{13}$ March J. and Olsen J. (1998) The Institutional Dynamics of International Political Orders //International Organization, vol.52, issue 4, pp. 943-69; Koremenos B. and Snidal D. (2003) Moving Forward, One Step at a Time //International Organization, vol. 57, issue 2, pp. 431-444.
} 
Различные организационные механизмы и структуры побуждают акторов, преследующих одну и ту же цель, выбирать разные стратегии по её достижению ${ }^{14}$.

Система управления в ЕС, и в том числе управления экономического, помещена в пространство политического соревнования, где становятся значимы партии, выборы, референдумы и идентичности, что, с точки зрения требований функциональной целесообразности, ведёт к снижению коэффициента её полезного действия. При этом трудно безболезненно перенести демократические нормы с национального уровня на наднациональный. Европейскому союзу теперь приходится справляться с иным набором задач, нежели в прошлом. Новые задачи требуют иных, нежели ранее, источников легитимности, обращение к которым сдерживается сохраняющей значимость национальной идентичностью ${ }^{15}$.

По-прежнему весьма важным представляется вопрос о том, почему в конкретных случаях государства - члены Европейского союза идут на делегирование наднациональным институтам или на объединение на европейском уровне всё большей власти по принятию решений. О делегировании мы говорим при наделении новыми полномочиями Европейской комиссии, Суда Европейского союза или Европейского центрального банка. Объединение суверенитета, в свою очередь, подразумевает переход к принятию решений большинством голосов (как, например, в Совете министров ЕС) по всё более широкому кругу вопросов. Американский теоретик Эндрю Моравчик, автор либерального межправительственного подхода к изучению интеграции, видит в подобном институциональном результате, прежде всего, вполне рациональную стратегию национальных правительств, которые хотят таким способом повысить надёжность исполнения всеми без исключения участниками достигнутых ими в рамках интеграционного объединения договорённостей ${ }^{16}$.

Как предсказывала в своё время неофункциональная теория ${ }^{17}$, каждый кризис, возникающий на пути европейской интеграции, порождает некие условия для передачи на наднациональный уровень новых функций и дальнейшего усиления европейских институтов. События недавнего прошлого не стали в этом смысле исключением. Оправданием подобной интегративной динамики может служить вера европейских элит в более высокую действенность (эффективность), которую способны продемонстрировать наднациональные институты по сравнению с национальными. Немаловажны также экономические выгоды, получаемые от интеграционного процесса всеми его участниками.

Выгоды интеграции (эффект её масштаба), как предсказывали неофункционалисты, побуждают участников к переориентации своего доверия, интересов и поведения с национального на наднациональный властный центр, институты которого уже наделены определённой юрисдикцией. В итоге дальнейшее развитие интеграции выступает в таком случае как следствие, во многом не преднамеренное, ранее уже предпринятых институциональных реформ, или как шаг, который нужно сделать, чтобы обеспечить, защитить производительность ранее предпринятых транснациональных реформ в изменившихся условиях.

Но описываемая таким образом функциональная интеграция никоим образом не ставит во главу угла понятие демократической легитимности. Напротив, массовая политика в такой

\footnotetext{
${ }^{14}$ De Canio S., Dibble C., Amir-Atefi K. (2000) The Importance of Organizational Structure for The Adoption of Innovations // Management Science, vol. 46, no. 10, October, pp. 1285-1299.

${ }^{15}$ Hooghe L. and Marks G. (2009) A postfunctionalist theory of European integration: From permissive consensus to constraining dissensus // British Journal of Political Science, vol.39, issue 1, pp. 1-23.

URL: https://www.unc.edu/ gwmarks/assets/doc/BJPS.postfunctionalism.2009.hooghe.marks.pdf.

${ }^{16}$ Moravcsik A. (1998) The Choice for Europe, Ithaca: Cornell University Press, p. 73.

${ }^{17}$ Schmitter Ph. (2005) Ernst B. Haas and the legacy of neofunctionalism // Journal of European Public Policy, vol. 12, issue 2: The Disparity of European Integration: Revisiting Neofunctionalism in Honour of Ernst Haas, pp. 255272.
} 
трактовке принципиально исключается из числа факторов, которыми должно определяться развитие интеграции по неофункциональным лекалам - как технократической «интеграции украдкой» (integration by stealth). Между тем во второй половине 2000-х годов в Европейском союзе предпочтения широкой публики и национальных политических партий стали обретать решающее значение с точки зрения дальнейшего распределения полномочий в рамках многоуровневой системы экономического управления, а европейская интеграция стала политизироваться. Наднациональная Европа с тех пор активно вторгается в национальную политику, а национальная политика - в принятие европейских решений, что невозможно объяснить, оставаясь в русле традиционной неофункциональной парадигмы.

Наблюдаемые в ЕС процессы не являются однонаправленными. При изучении институциональной архитектуры ЭВС, помимо прочего, необходимо брать в расчёт, что в Европейском союзе не произошло и не происходит явного, однозначного перетекания суверенитета с национального на наднациональный уровень. Мы видим, как распределение компетенций, их содержания и масштаба там постоянно перекраивается в ходе борьбы за власть, которую ведут между собой национальные и европейские акторы, представляющие различные публичные (государственные) или частные интересы.

Предлагаемая вниманию читателя работа включает четыре главы.

В первой главе мы выясним, какое отношение к легитимности институтов Европейского союза и, прежде всего, тех среди них, что причастны к функционированию ЭВС, имеют принцип субсидиарности и парадигма многоуровневого управления, которые сопровождали развитие европейского интеграционного процесса, начиная с середины 1980-х годов.

Вторая глава посвящена европейскому валютному союзу, экономическим основаниям для перехода на единую европейскую валюту и благоприятным политическим условиям, которые сложились для такого перехода в 1990-е годы. В таком контексте глава призвана ответить на вопрос, почему долговременный результат этой инициативы принёс с собой немало разочарований. Специальное внимание при этом уделено проблеме легитимности ЕЦБ.

Третья глава знакомит читателя с развивающимися институтами Европейского банковского союза. В фокусе - политика его строительства и сохраняющаяся в данной сфере дифференциация (дифференцированная интеграция).

В четвёртой главе речь идёт о жёстких и мягких формах координации бюджетнойналоговой и экономической политики национального уровня на европейском уровне, а также о ведущейся в ЕС дискуссии по поводу необходимых на будущее общих инструментов экономической стабилизации.

Наконец, в заключении автор приходит к выводу, что более глубокий фискальный союз для ЕС, о котором много говорят сегодня, не выглядит ни необходимым, ни достаточным условием для эффективной политики экономической стабилизации в интегрированной Европе с единой валютой. Вместе с тем наметившаяся большая фискальная интеграция затрагивает самое ядро демократических систем стран-участниц еврозоны. Поэтому европеизацию в фискальной сфере - будь то укрепление межправительственного сотрудничества или передача на верхний уровень власти в ЕС все новых компетенций - нельзя сегодня считать изменением само собой разумеющимся и не требующим дополнительных раздумий со стороны политологов и широкой публики. 


\section{Глава 1}

\section{МНОГОУРОВНЕВАЯ СИСТЕМА, СУБСИДИАРНОСТЬ И ЛЕГИТИМНОСТЬ}

Европейский союз международные эксперты привычно трактуют как нечто среднее между государством и международной организацией ${ }^{18}$. Система ЕС уникальна (sui generis) и включает такие беспрецедентно сильные наднациональные институты, как Европейская комиссия, Европейский парламент, Суд ЕС и Европейский центральный банк, а также разнообразные европейские агентства, некоторые из которых также наделены внушительными наднациональными полномочиями. Принципы верховенства и прямого действия определяют соотношение права Европейского союза с правовыми системами государств-членов.

Обнаруживается немало убедительных оснований, позволяющих рассматривать ЕС как высокоразвитую международную организацию. В качестве таковой для исследователейполитологов Союз, в частности, особенно интересен тем, что его допустимо рассматривать как лабораторию, в которой наблюдается зарождение и развитие демократических структур вне государств-членов (а также препятствия, с которыми они сталкиваются) ${ }^{19}$. В теории международные организации могут функционировать на основании межправительственности - или же опираясь на наднациональный принцип.

В условиях межправительственности национальные государства, вступая в международную организацию, остаются ключевыми политическими акторами, тогда как общим институтам отводится второстепенная роль по обеспечению государствам платформы для взаимодействия. Наднациональность, в свою очередь, подразумевает такую структуру властных органов, которая больше напоминает федерацию, нежели традиционную международную организацию, но не идентична последней. В отличие от федеративного государства, в наднациональном объединении государства-члены формально сохраняют суверенитет, но некоторой частью суверенных прав они при этом делятся с наднациональными институтами - или уступают им её. Полный государственный суверенитет может быть восстановлен государствами путём добровольного выхода из наднациональных договорённостей (что подтверждается реализуемым на наших глазах драматичным опытом выхода из Европейского союза Великобритании). Но и наднациональные институты до известного предела автономны от правительств государств-членов. Они способны преследовать определённые (собственные) цели, в том числе и такими способами, которые изначально не предусматривались правительствами, делегировавшими им власть. В Европейском союзе мы наблюдаем пример сложного сочетания наднациональности и межправительственности (при этом было бы в корне неверно утверждать, что последний принцип продолжает сдавать в ЕС свои позиции), а в последнее время также возникновение их не существовавших прежде причудливых гибридных форм.

Наднациональность есть такое качество, которое, по определению, может быть присуще только многоуровневой политической организации. Как нам известно,

\footnotetext{
${ }^{18}$ См., к примеру: Hlavac M. (2010) Less than a State, More than an International Organization: The Sui Generis Nature of the European Union (December 2). Available at SSRN: https://ssrn.com/abstract=1719308 or http://dx.doi.org/10.2139/ssrn.1719308.

${ }^{19}$ Jensen Th. (2009) The Democratic Deficit of the European Union // Living Reviews in Democracy, vol. 1, pp.1-9. Available at: https://www.lrd.ethz.ch/index.php/lrd/article/view/lrd-2009-2/8.
} 
региональная интеграция привела к оформлению в ЕС открытой политической системы, включающей разные уровни: не только национальный и наднациональный, но также субнациональный (регионы внутри государств) и даже глобальный (уровень глобального управления). Вследствие этого, начиная с 1980-х годов, на пространстве ЕС осуществляется организационное усложнение политического процесса и умножение методов управления. Важнейшей особенностью современной европейской политики в данной связи является то, что на смену традиционному, суверенному национальному государству в интегрированной Европе пришло государство постсуверенное. Оно плотно включено в многоуровневую систему глобального управления и активно сотрудничает в ее рамках с другими государствами и наднациональными институтами при решении конкретных проблем.

Постсуверенное государство, выступающее как часть системы многоуровневого управления, функционирует в глобализированном мире, где разные сферы политики ему приходится делить с другими акторами. Это порождает особенно высокую степень взаимозависимости на европейском уровне, ограничивающую способность отдельных стран к эффективным самостоятельным действиям, особенно в таких областях, как защита окружающей среды, регулирование транснациональных потоков в торговле и финансах (последнее особенно важно в контексте настоящего исследования), противодействие транснациональным рискам.

В экономическом управлении в Европейском союзе, понимаемом как многоуровневый процесс выработки, принятия и имплементации технократических и политических решений, которые касаются функционирования Единого внутреннего рынка и Экономического и валютного союза, задействованы наднациональные и международные институты, национальные правительства и парламенты, транснациональные корпорации, социальные партнёры, эксперты и граждане. Этот процесс преодолевает государственные границы и разворачивается на национальном и наднациональном уровнях одновременно ${ }^{20}$.

Общую парадигму при анализе политики ЕС задает, соответственно, концепция многоуровневого управления ${ }^{21}$. Исходя из неё, принятие решений в европейских рамках находится одновременно в компетенции акторов различного уровня. Понятие многоуровневого управления широко признано в среде специалистов, которые занимаются изучением Европейского союза, в качестве предпочтительного способа концептуализации его политической системы ${ }^{22}$. Это понятие уже длительное время сохраняет свою полезность, помогая высветить взаимодействие институтов ЕС и государств-членов в процессе принятия и имплементации общих решений.

Многоуровневое управление трактуется как некая, до известной степени автономная от государств, включенных в неё, система принятия и исполнения обязывающих государства решений. В ней участвуют многочисленные публичные и частные акторы разного ранга. Под уровнями мы понимаем здесь всевозможные юрисдикции - территориальные, функциональные или отраслевые, - составляющие совокупность правомочий определенных органов власти. В рамках многоуровневой системы они не зависят друг от друга формально, однако являются функционально взаимосвязанными и вовлечены в непрерывные переговоры/делиберацию/имплементацию.

\footnotetext{
${ }^{20}$ Подробнее см.: Стрежнева М.В. (2009) Структурирование политического пространства в Европейском союза // Мировая экономика и международные отношения, № 12, с. 38-49.

${ }^{21}$ Hooghe L., Marks G. (2001) Multi-Level Governance and European Integration, Lanham, Maryland: Rowman \& Little.

${ }^{22}$ Hix S. (2005). The Political System of the European Union, Basingstoke: Palgrave, 2nd edn.; Jachtenfuchs M. (2006). The European Union as a Polity (II) //Knut Erik Jørgensen, Mark A. Pollack, and Ben Rosamond (eds.), Handbook of European Union Politics, London: Sage, 159-174; Громогласова Е.С. (2009). Теория и практика политического управления в Европейском союзе, М.: ИМЭМО РАН.
} 
Подобная система не предписывает заранее всеобъемлющую исключительную компетенцию ни одному из уровней в отдельности. Она не позволяет выстроить жёсткую иерархию политической власти ${ }^{23}$. Но концепт многоуровневого управления (как подтверждает и проведенный в этой работе анализ) помогает учёным обнаружить до поры до времени скрытые процессы, которые, через постепенное накопление массы политических решений и политическую мобилизацию, способны привести к качественной трансформации регионального объединения, структур его стран-участниц и даже самого европейского государства как такового.

Многоуровневое управление непременно носит сетевой характер. Транснациональные политические сети, с одной стороны, позволяют найти своё место в ЕС национальным администрациям, а с другой стороны, открывают перед Комиссией дополнительные возможности, чтобы в конкретных случаях добиваться политического преимущества над национальными правительствами. Как видится, при изучении политических аспектов в развитии ЕС суть дела не в том, чтобы однозначно противопоставить наднациональность в ЕС межправительственному подходу, а как раз в том, чтобы рассмотреть, как в калейдоскопе, как меняется со временем (и с какими политическими последствиями) конфигурация взаимосвязей между правительствами и европейскими институтами в различных сферах управления.

Однако парадигма многоуровневого управления не только служит для описания, объяснения отношений между разными уровнями управления. В Европейском союзе она, что многократно существеннее, задаёт реальную норму этих отношений. Меняющееся соотношение компетенций на различных уровнях власти в ЕС приводит к тому, что отдельные направления европейской политики (в том числе с элементами перераспределения финансовых средств) однажды становятся допустимыми или даже целесообразными, чего ранее не наблюдалось. Поэтому идея многоуровневого управления имеет непосредственное отношение к вопросу о политической власти в Европейском союзе ${ }^{24}$.

Лизбет Хуг и Гари Маркс описывали многоуровневое управление как рассредоточение процессов принятия властных решений по множественным территориальным уровням. Первый толчок к оформлению в ЕС многоуровневой системы, как было ими отмечено, был дан со вступлением в силу Единого европейского акта 1986 г. Переход к систематическому применению квалифицированного большинства при голосовании в Совете министров ЕС и наделение широкими полномочиями Европейского парламента было осуществлено на его основании. Тем самым было обеспечено серьёзное ограничение национального права вето, возобладавшего в европейском интеграционном объединении со времени Люксембургского компромисса в 1960-х годах. До середины 1980-х годов право вето надёжно гарантировало каждой стране - участнице ЕЭС, что никакие важные политические решения не будут имплементированы в интеграционном объединении без её согласия.

Но почему государства-члены согласились в какой-то момент передать столь весомую часть своего суверенитета органам более высокого порядка? По замечанию Хуг и Маркса, передача власти снизу-вверх «ограждает определённый политический курс от попыток следующего правительства изменить его в будущем». Она также «избавляет главу правительства от бремени ответственности» за выполнение определённой политики ${ }^{25}$.

Таким образом, по их довольно откровенному предположению, начиная с 1980-х годов, часть суверенитета была решительно передана правительствами наверх, чтобы им свободнее было проводить в Европейском сообществе политику, которая, как сами они ожидали, легко

\footnotetext{
${ }^{23}$ Piattoni S. (2009) Multi-level Governance: a Historical and Conceptual Analysis // European integration, vol. 31, no 2, pp. 163-180.

${ }^{24}$ Vos H., Boucke T., Devos C. (2002) The conditio sine qua non of the added value of regions in the EU - upper-level representation as the fundamental precondition // Journal of European Integration, vol. 24, no 3, pp. 201-218.

${ }^{25}$ Hooghe and Marks. Op. Cit., p. 72.
} 
могла бы вызвать внутриполитическую оппозицию, быть опротестована или отвергнута политическими оппонентами внутри отдельных стран.

С самого своего зарождения многоуровневое управление в ЕС было сосредоточено на экономических вопросах. При этом его архитекторам было понятно, что Единый внутренний рынок станет оказывать давление сверху-вниз на национальные государства благосостояния, вызывая политическую мобилизацию населения с требованиями к национальным правительствам прекратить возникающую эрозию мер по социальному обеспечению. Многоуровневое управление обещало «прикрыть» правительства от последствий такой мобилизации. Широкое внедрение квалифицированного большинства при голосовании, в частности, означает, что отдельные правительства могут «без проблем» позволить себе демонстративно протестовать против неолиберального курса европейской экономической политики, при этом продолжая его проводить у себя дома. Их возражения не задержали бы продвижение к завершению ЕВР на наднациональном уровне, поскольку сопротивления одной страны или пары-тройки стран уже недостаточно было бы, чтобы перечеркнуть стабильный неолиберальный курс для ЕС в целом. Национальные политики в некоторых странах ЕС могли заниматься либерализацией национальных рынков, считая её необходимой и при этом сбрасывая «вину» за либерализацию в глазах недовольной части общества на Брюссель ${ }^{26}$ (именно с подобным не слишком добросовестным манёвром во внутренней политике не хватило искусства справиться в своё время премьер-министру Великобритании Дэвиду Камерону, что и привело к вышедшей из-под его контроля ситуации Брексита, которую пришлось расхлёбывать его политическим наследникам).

Предстоявшее в первой половине 2000-х годов расширение интеграционного объединения вследствие включения в него стран Центральной и Восточной Европы подталкивало руководство ЕС к расширению арсенала практик многоуровневого управления ${ }^{27}$. К примеру, Маастрихтский договор 1992 г. дал ход укоренению понятия и практики европейского «ядра». Чтобы избежать британского вето, в валютном союзе была предусмотрена возможность добровольного устранения (opt-out) от присоединения к нему. С другой стороны, утвердилось положение, в согласии с которым группа стран могла теперь пойти на крупную политическую инновацию без участия в ней (по крайней мере первоначального) остальных государств-членов.

Однако ныне в ЕС предпочтения широкой публики и национальных политических партий становятся более значимыми с точки зрения распределения полномочий политической власти в рамках многоуровневой системы, а европейская интеграция активно политизируется. Иными словами, функциональные рецепты устройства многоуровневой политической системы ЕС, исходившие от таких экспертов, как Хуг и Маркс, довольно быстро перестали работать так, как они первоначально задумывались.

Ранние работы по многоуровневому управлению рассматривали в основном особенности процесса управления в ЕС, причём в основном в комплиментарном ключе ${ }^{28}$. Впоследствии возникла и получила мощное продолжение дискуссия по вопросу о том, как многоуровневые характеристики системы ЕС могут сказываться на его демократической легитимности ${ }^{29}$. В известном смысле, как это ни парадоксально, многоуровневое управление

\footnotetext{
${ }^{26}$ Culpepper Pepper D, Hall Peter A. and Palier Bruno, eds. (2006) Changing France: The Politics that Markets Make. London: Palgrave.

${ }^{27}$ Борко Ю.А. Взаимосвязь процессов расширения и углубления европейской интеграции // Расширение Европейского Союза и Россия / Под. ред. О.В. Буториной и Ю.А. Борко. М.: Деловая литература, 2006, с. 11-42 ${ }^{28}$ Marks G. (1992) Structural Policy in the European Community// A. Sbragia (ed.) Europolitics: Institutions and Policymaking in the 'New' European Community, Washington: Brookings Institution, pp. 191-224.

${ }^{29}$ Benz A. \& Papadopoulos Y. (2006) Actors, institutions and democratic governance: Comparing across levels // A. Benz \& Y. Papadopoulos (eds.) Governance and democracy. Comparing national, European and international experiences, London: Routledge, pp. 273-295.
} 
в принципе получило развитие в Европейском союзе и из-за того тоже, что в определённый момент возник запрос на демократическое управление на уровне, который выше национальногосударственного. В многоуровневости усматривалась отныне некая возможность поставить нерегулируемые транснациональные процессы под демократический контроль, оформленный вне национальных рамок, восстановив таким образом «конгруентность» социальных трансакций и процессов принятия политических решений ${ }^{30}$. Отталкиваясь от такой точки зрения, Лизбет Хуг и Гари Маркс утверждали, к примеру, что многоуровневые характеристики политической системы ЕС, несмотря ни на что, в целом способствуют её демократизации. По их предположениям, многоуровневость сама по себе даёт дополнительные возможности для расширенного политического участия в децентрализованной системе, которая заведомо более эффективна, нежели устаревающее традиционное государство модерного типа, и решительно превосходит его в нормативном отношении ${ }^{31}$.

Но по представлениям многих других авторов, которые сегодня выглядят, как минимум, не менее убедительно, в ЕС с внедрением многоуровневости стало происходить распыление регулирующей власти и налицо оказались тенденции непрозрачного переговорного торга между разными властными уровнями и между властью и отдельными общественными группами. Из-за этого ключевые ценности демократического правления, напротив, часто приносятся в Европейском союзе в жертву нахождению компромиссов, достижению консенсуса и искомой эффективности управления в элитном кругу 32 .

Как национальные правительства, так и Европейский союз в принципе заинтересованы в успешном проведении коллективной политики, адресующейся к крупным политическим и экономическим проблемам, с которыми государствам, действующим поодиночке, справиться невозможно. При этом национальные государства претендуют на легитимность, являясь представительными демократиями, тогда как легитимность ЕС, если понимать таковую как легальность (законность), имеет своим исходным источником главным образом договоры, в которых участвуют те же национальные государства, действуя в соответствии с международным правом ${ }^{33}$.

Налицо сосуществование разных форм легитимности (правомерности) - национальной и международной, в силу чего, в особенности если государства-члены отступают от de facto сформированного европейского конституционного порядка, прибегая к международным соглашениям вне правового поля ЕС (упомянем здесь, в качестве примеров, Договор о Европейском механизме стабильности 2011 г. и Договор о стабильности, координации и управлении в экономическом и валютном союзе 2012 г., которые были заключены в ответ на кризис в еврозоне и к обсуждению которых мы ещё будем неоднократно возвращаться), возникает потенциал для обострения нормативного конфликта (т.е. конфликта между нормами, которым должны подчиняться действия и институтов ЕС, и государств-членов) $)^{34}$. Наличие такого конфликта шире открывает «окно» для подключения к процессам многоуровневого европейского управления конституционным судам государств-членов ${ }^{35}$.

\footnotetext{
${ }^{30}$ Zurn M. (2000) Democratic Governance beyond Democratic Governance Beyond the Nation-State: The EU and Other International Institutions // European Journal of International Relations, vol. 6 issue 2, pp. 183-221.

${ }^{31}$ Marks G. \& Hooghe L. (2004) Contrasting visions of multi-level governance // In I. Bache \& M. Flinders (eds.) Multilevel governance, Oxford: Oxford University Press, p. 16.

${ }^{32}$ Peters B. G. \& Pierre J. (2004) Multi-level Governance and Democracy: A Faustian Bargain? // I. Bache \& M. Flinders (eds.) Multi-level Governance, Op. Cit., p. 85.

${ }^{33}$ Lenaerts K. and Marlies D. (2002) New Models of Constitution-Making in Europe: The Quest for Legitimacy // Common Market Law Review, vol. 39, pp.1217-1253.

${ }^{34}$ Schweiger Ch. (2016) Exploring the EU's Legitimacy Crisis: The Dark Heart of Europe, Cheltenham, UK, Northampton, MA, USA: Edward Elgar.

${ }^{35}$ Подробнее см.: Fabbrini F. (2014) The Euro-Crisis and the Courts: Judicial Review and the Political Process in Comparative Perspective // Berkeley Journal of International Law, vol. 32, issue 1, pp. 64-123. Available at: https://scholarship.law.berkeley.edu/cgi/viewcontent.cgi?article=1449\&context=bjil.
} 
Впрочем, до тех пор, пока политика ЕС, поддерживаемая Европейским парламентом и Европейским советом, не встречает последовательного массового сопротивления внутри отдельных стран-участниц, реального столкновения разных форм легитимности в таком понимании может и не возникнуть.

Понятие многоуровневого управления тесно связано с идеей субсидиарности. Субсидиарность предполагает активную роль государства в обществе. Вместе с тем это принцип децентрализации, который подразумевает, что центральная (государственная) власть должна выполнять только вспомогательную (относительно общества) роль. Как научный и специальный концепт, субсидиарность сегодня широко применяется не только в области политического управления и в политологии в целом, но также в кибернетике, менеджменте и в военном командовании.

В Европейском союзе принцип субсидиарности является неотъемлемой частью практики многоуровневого управления (ст. 5.3 Договора о Европейском союзе - ДЕС и протокол №2 о применении принципов субсидиарности и пропорциональности) ${ }^{36}$. Оба они имеют дело с правовыми, политическими, экономическими, структурными и циклическими аспектами взаимодействия европейского, национального и субнационального уровней власти. Согласно политико-правовому принципу субсидиарности, как его трактуют в Союзе, в тех областях, которые не отнесены к исключительной компетенции ЕС, принятие европейских мер считается допустимым только тогда, когда целей предполагаемого действия не удаётся достичь удовлетворительным образом самим национальным государствам (как власти более низкого уровня), действующим самостоятельно. Соблюдение данного принципа в ЕС юридически обязательно и подлежит судебному контролю.

Согласно статье 5.3 ДЕС, для вмешательства институтов Евросоюза в экономическое управление в соответствии с принципом субсидиарности необходимо наличие трёх условий:

(a) та сфера, о которой идёт речь, не относится к исключительной компетенции ЕС;

(в) поставленные задачи не могут быть в удовлетворительной степени выполнены самим государствами-членами;

(c) Евросоюзом соответствующие действия могут быть выполнены более успешно (добавленная стоимость).

Данный принцип присутствовал уже в Едином европейском акте 1986 г., но там он был отнесён исключительно к экологической политике. В Маастрихтском договоре 1992 г. субсидиарность была возведён в статус общего принципа европейского права, что следует непосредственно связать с ростом значимости для ЕС в тот период вопроса о дефиците демократии, к подробному обсуждению которого мы вернёмся несколько позже.

Во многих странах ЕС возникли опасения, что учреждённый на базе Маастрихтского договора Европейский союз заберёт себе слишком много полномочий (такие взгляды были особенно распространены в Великобритании) либо что он неправомерным образом проигнорирует полномочия субъектов федерации в некоторых государствах-членах (об этом сильнее беспокоились в Германии). Внедрение данного принципа сулило оздоровление ситуации в обоих упомянутых случаях.

Субсидиарность стали рассматривать в ЕС как средство (причём, как оказалось впоследствии, средство не слишком широкого действия) для налаживания сотрудничества между институтами Европейского союза и национальными парламентами ${ }^{37}$. На сегодняшний день в наибольшей степени к этому удалось продвинуться с внедрением на основании

\footnotetext{
${ }^{36}$ Horga I., Florian G. L. (2011) Multilevel Governance (MLG) and Subsidiary Principle in White Paper of MLG of the Committee of the Regions (COR) // Ioan Horga, Iordan Bărbulescu, Adrian Ivan, Mykolia Palinchak, Istvan Suli-Zakar (eds.) Regional and cohesion policy: insights into the role of the partnership principle in the new policy design, Oradea, pp.159-165. Available at: http://nbn-resolving.de/urn:nbn:de:0168-ssoar-331537.

${ }^{37}$ Kiiver P. (2011) The Early-Warning System for the Principle of Subsidiarity: The National Parliament as a Conseil d'État for Europe // European Law Review, vol. 36, no 1, p.100
} 
Лиссабонского договора 2007 г. механизма раннего предупреждения. Речь идёт о том, что теперь национальные парламенты наделены правом отслеживать и оценивать соблюдение принципа субсидиарности в законодательных предложениях ЕК, которым, после их принятия легислатурой, предстоит стать правовыми актами ЕС (регламентами и директивами). Получив (в обязательном порядке) законопроект от Комиссии, национальные парламенты в течение восьми недель вправе донести до институтов ЕС аргументированное мнение с объяснением того, почему, по их оценке, он не соответствует принципу субсидиарности.

Если в пользу такого мнения совокупно собрано не менее трети всех голосов однопалатных национальных парламентов и палат двухпалатных национальных парламентов (или четверти голосов, когда дело касается вопросов свободы, безопасности и правосудия), Комиссия вынуждена вернуться к рассмотрению своего законодательного предложения («жёлтая карточка»). ЕК должна в таком случае дать объяснения, почему она намерена настаивать на сохранении своего предложения в неизменном виде, внести в него изменения или отказаться от него. Иными словами, Комиссия не обязана непременно вносить изменения в предлагаемый ею законопроект, а национальные парламенты не вовлекаются непосредственно в формулирование правового акта и не могут предложить к нему собственные поправки.

С 2009 г., когда Лиссабонский договор вступил в силу, данный механизм использовался всего трижды. В первом случае в (связи с законодательным предложением о праве на стачку - предложение Монти II) ${ }^{38}$ Комиссия попыталась отреагировать на обвинения в том, что на Едином внутреннем рынке экономическим свободам обычно отдается предпочтение перед такими основополагающими свободами, как право на забастовку. Она предложила свой вариант разрешения споров в случаях трансграничного характера. Но против её предложения высказались 12 национальных парламентов/палат с 19 голосами (из 56), которые посчитали, что решение соответствующих вопросов нужно оставить на национальном уровне. Самую активную роль в противодействии законопроекту взял на себя датский фолькетинг. Комиссия в итоге отказалась от своего предложения - но уточнила, что сделала это из-за политических разногласий в Совете по данному вопросу, а не непосредственно из-за «жёлтой карточки», предъявленной ей национальными парламентами.

Второй случай касался предложения о европейском офисе общественного прокурора $(\text { Европейской прокуратуре })^{39}$ - против создания новой организации по расследованию дел о хищениях из бюджета ЕС было подано 18 голосов. В данном случае Комиссия решила не отказываться от этого законопроекта, судьба которого была передана ею в руки Совета и Европейского парламента, одобривших, в конечном счёте, эту инициативу ${ }^{40}$.

В третьем случае решалась судьба директивы по вопросу откомандирования в другие страны ЕС работников, производимого в рамках предоставления услуг ${ }^{41}$. По терминологии $\mathrm{EC}$, в данном случае речь идёт о гражданах Европейского союза, временно направляемых в принимающую страну ЕС своим нанимателем, который в этой стране занимается предоставлением каких-то услуг. Например, если польская строительная компания занимается возведением дома в Германии, то она может временно направить туда рабочих из Польши, у которых польские контракты и, соответственно, зарплата пониже, чем у строителей, которых можно было бы нанять непосредственно в Германии. Откомандированные работники из стран

\footnotetext{
${ }^{38}$ Proposal for a Council regulation on the exercise of the right to take collective action within the context of the freedom of establishment and the freedom to provide services, COM (2012) 130 final.

${ }^{39}$ Proposal for a Council Regulation on the European Public Prosecutor's Office, COM(2013) 534 final.

${ }^{40}$ По планам на сегодняшний день, Европейская прокуратура откроется в 2020 году в Люксембурге, в её создании первоначально, по правилам продвинутого сотрудничества, будут участвовать 20 стран ЕС.

${ }^{41}$ Proposal for a Directive of the European Parliament and of the Council amending Directive 96/71/EC of the European Parliament and of the Council of 16 December 1996 concerning the posting of workers in the framework of the provision of services, COM (2016) 128 final.
} 
Центральной и Восточной Европы (всего около 2 млн. человек в странах Европейского экономического пространства и в Швейцарии - при этом из Польши исходит до четверти от общего числа откомандированных) составляют всего $0,9 \%$ от общего числа занятых в Европейском союзе, в силу чего бурные политические дебаты по поводу внесения изменений в соответствующую директиву всё же вызывают некоторое удивление. Помимо строителей, чаще всего откомандированными могут быть работники сферы финансовых услуг, образования и социальные работники. Средний срок пребывания откомандированных в принимающей стране составляет 98 дней.

Против соответствующего законопроекта было выдвинуто 14 голосов, преимущественно парламентами стран Центральной и Восточной Европы. Но Комиссия приняла решение о его сохранении в неизменном виде.

Как показала практика, институционализация принципа субсидиарности, вопреки надеждам, не слишком помогла с устранением демократического дефицита в ЕС, но фактически, напротив, укрепила в нём черты функционализма. Ведь данный принцип, если присмотреться к нему внимательней, выстроен на идее сравнительной продуктивности (функциональности) в достижении целей интеграции, которые сами по себе рассматриваются при этом как однозначные, якобы непротиворечивые. Заложенная в нём вера в полезность для укрепления демократии диалога между различными уровнями управления, как представляется, исходила из несколько упрощённой интерпретации проблемы, которую принцип субсидиарности призван был решать.

Вспомним ещё раз, что Европейское экономическое сообщество создавалось как функциональное объединение, ориентированное на создание общего рынка. В то же время его государства-члены должны были оставаться местом сосредоточения для демократического самоопределения по широкому кругу других вопросов. Но вместо того, чтобы отграничить пространство политического действия с помощью принципа субсидиарности, функциональное размежевание компетенций со временем превратилось в средство постепенного, но неуклонного расширения власти ЕС ${ }^{42}$.

Есть два обстоятельства, при которых, с точки зрения принципа субсидиарности, наднациональные институты смотрятся выигрышней, нежели государства-члены, в плане имеющихся у них возможностей обеспечения эффективности экономической политики. Вопервых, это трансграничные побочные эффекты экономической деятельности (эффекты перелива), ведущие к так называемым экстерналиям (некомпенсируемым воздействиям, в данном случае отрицательным, одной стороны на другую). Если политика, проводимая в национальных рамках, негативно влияет на состояние экономики других государств-членов, но национальным правительством это игнорируется, то проводимая этим национальным правительством политика должна быть признана неблагоприятной с точки зрения интересов Европейского союза в целом.

Во-вторых, это все политические функции, характеризующиеся экономией от масштаба, что позволяет повысить отдачу от проводимой политики, если её проводить на более высоком уровне управления. Исходя из этого, властные компетенции стоит передавать с национального на европейский уровень только в тех случаях, когда самостоятельные национальные меры приводят к значительным негативным внешним последствиям или не приносят достаточного выигрыша в плане эффективности.

В ЭВС денежно-кредитная сфера является той областью, в которой налицо высокая степень наднациональной централизации компетенций. Валютный союз, как минимум, требует, чтобы обменные курсы национальных валют стран, входящих в него, были зафиксированы в необратимом порядке. Отсюда необходимость передачи ответственности за

${ }^{42}$ Bartl M. (2015) The Way We Do Europe: Subsidiarity and the Substantive Democratic Deficit // European law Journal, vol. 21, issue 1, pp. 23-43. 
денежно-кредитную политику единому институту (ЕЦБ), поскольку без такой централизации деньги, которые эмитирует любой национальный центральный банк, будут влиять на экономику в пределах всего Союза, а не только в национальных рамках, в то время как другие государства-члены не смогут защититься от вытекающих из этого последствий.

В рамках подобной логики, в то время как денежно-кредитную политику следует сразу же отнести на наднациональный уровень, на национальные центральные банки можно попрежнему полагаться как на функциональный элемент системы валютного союза. Кроме того, они могут сохранять и собственные исключительно важные обязанности (например, как это и было ранее в сфере банковского надзора в Европе, что отражено в главе 3 данной книги).

Как мы видим, идея субсидиарности не просто служит основополагающей установкой при распределении власти между национальными государствами и наднациональными институтами в ЕС. Она прямо подразумевает политически децентрализованный рынок такую политико-экономическую организацию, в которой решения принимаются либо самими индивидами, либо на уровне, который близок к ним в максимально возможной степени. При этом в европейском Экономическом союзе проведение единой европейской экономической политики уже не рассматривали как необходимое требование для перехода к валютной интеграции. В частности, в том, что касается бюджетной политики, предпочтение в Брюсселе в 1990-е годы было отдано сочетанию национальной автономии, бюджетной дисциплины государств и их добровольной координации своих действий.

В то же время в долговременной перспективе финансовая стабильность в рамках валютного союза может быть обеспечена только тогда, когда государственные финансы его государств-членов отвечают требованию самодостаточной динамической устойчивости. Неплатёжеспособность национального правительства, либо даже одна только убедительная опасность таковой, оказывают сильное давление на Европейский центральный банк, подталкивая его к нежелательному смягчению своей политики, а национальные государства к тому, чтобы выручить из беды обанкротившегося партнёра. Следовательно, бюджетная дисциплина со стороны национальных правительств является жизненно важным вопросом для ЭВС в целом. Так как на рыночные силы нельзя в полной мере полагаться, если следует непременно избежать опасности национальных дефолтов, то обязательными в такой схеме становятся общие для ЕС правила по предотвращению «чрезмерных» национальных дефицитов.

Впрочем, принцип субсидиарности, взятый в абстрактном виде, открыт для многочисленных интерпретаций - в том числе за пределами той, которая возобладала в ЕС. При написании Маастрихтского договора его авторы воздержались от составления исчерпывающего списка тех областей, в которых наднациональное действие могло бы быть необходимым и эффективным. Они не предложили конкретных критериев, на основании которых можно было бы судить о действенности и целесообразности той или иной наднациональной акции. В этом смысле принцип субсидиарности в Европейском союзе остаётся скорее общим политическим принципом, нежели источником чётких указаний в отношении выбора конкретного институционального дизайна. Но политическая философия, которую он выражает (по поводу того, что к большей централизации следует прибегать, только если для этого присутствует веская причина) считается в ЕС безусловной.

Общее определение, или описание, принципа субсидиарности было предложено в своё время несколькими авторами. Согласно авторитетному мнению Дж. Бермана, субсидиарность выражает предпочтения в пользу управления на самом низком из местных уровней, на котором только могут быть достигнуты те цели, которые продекларировала власть ${ }^{43}$. В другом случае говорится о том, что «субсидиарность имеет целью наделить властью граждан и укрепить

\footnotetext{
${ }^{43}$ Bermann G. A. (1994) Taking Subsidiarity Seriously: Federalism in the European Community and the United States // Columbia Law Review, vol. 94, no. 2, pp. 339-344.
} 
демократию, поощряя процессы принятия решений, которые ближе к тому региону или к той проблеме, о которой идёт речь» ${ }^{44}$. В обоих этих высказываниях отражено широко распространённое мнение по поводу того, что субсидиарность по сути своей родственна демократии либо, так или иначе, способствует её распространению. Но сегодня в этом, впрочем, уместно усомниться.

На самом деле при посредстве этого принципа вопросы, вызывающие общественную озабоченность, могут быть, при желании, устранены из сферы, где решения принимаются демократическим путём. При этом задачи и функции политической власти могут быть возложены на определенные органы или уровни управления в институциональной иерархии, не принимая в расчёт необходимость прислушиваться к мнению граждан.

По определению, принятая в ЕС версия субсидиарности действительно предусматривает наделение функциями управления самого низкого уровня власти из всех возможных. Низшие уровни власти при этом рассматриваются как заведомо более демократичные по той причине, что они ближе к людям и поощряют участие обычных людей в политическом процессе. Они также считаются более работоспособными, потому что им приходится постоянно конкурировать за финансы и жителей, и они могут непосредственно учесть в своей политике предпочтения граждан. Но если орган более высокого уровня способен лучше справляться с поставленной задачей (исходя из определённого круга интересов, а также ценностей эффективности, демократии и свободы), то причины для поручения той же задачи более низкому уровню власти в Европейском союзе в принципе исчезают. Оспорить сделанный на таких основаниях выбор (в пользу более высокого уровня власти) уже можно только с помощью аргументов, касающихся его ожидаемой продуктивности либо эффективности, но не демократичности.

Согласно подходу, принятому в ЕС, национальное действие (формально) является правилом, а действие со стороны Союза - исключением. Но по сути у субсидиарности в ЕС две стороны: во-первых, Союз должен воздерживаться от вмешательства, когда искомые цели могут быть более действенно или надлежащим образом достигнуты государствами-членами; во-вторых, Союз, в случае необходимости, должен вмешаться, чтобы действовать эффективно. Таким образом, институты ЕC (начиная с Европейской комиссии и ЕЦБ) формально связаны требованиями не только воздержания от действия, так и вступления в него.

Обсуждение перспективы внедрения принципа субсидиарности в Европейском союзе шло особенно бурно в период 1980-х - 1990-х годов. Точнее было бы сказать, что принцип субсидиарности и парадигма многоуровневого управления сопровождали развитие европейского интеграционного процесса со времени начала выработки Маастрихтского договора. К середине 1980-х годов разгорелись споры по поводу уточнения магистрального направления в дальнейшем развитии европейской интеграции. При этом желательно было выработать общее согласие всех участников в вопросе о том, как распределять компетенции между разными уровнями власти в политической системе ЕС. В этой связи и привлёк к себе особое внимание принцип субсидиарности.

Жак Делор в 1989 г., будучи главой Комиссии, видел в его применении путь к тому, чтобы примирить «европейскую власть, способную справиться с проблемами нашего времени», с «абсолютной необходимостью сохранить наши корни в форме наций и регионов» ${ }^{45}$. Главным политическим оправданием для внедрения субсидиарности в тот период послужили ожидания, что, при нарастании наднациональных черт, он всё же позволит предотвратить чрезмерную наднациональную централизацию, то есть передачу слишком большого числа функций с национального (и субнационального) на наднациональный

\footnotetext{
${ }^{44}$ Evans M. and Augusto Zimmermann A. (2014) The Global Relevance of Subsidiarity: An Overview // Michelle Evans and Augusto Zimmermann (eds.) Global Perspectives on Subsidiarity, New York: Springer, p. 2.

45 Address given by Jacques Delors (Bruges, 17 October 1989). Available at: https://www.cvce.eu/content/publication/2002/12/19/5bbb1452-92c7-474b-a7cf-a2d281898295/publishable_en.pdf.
} 
уровень ${ }^{46}$. Такую заботу будировали имевшие широкое хождение представления о том, что некоторые функции в системе ЕС нужно считать исключительно делом органов менее высокого уровня, а именно национальных государств. Отсюда следовало, что эти функции никогда и ни в коем случае не подлежат подчинению наднациональным процедурам принятия решений.

Для разных подходов к субсидиарности характерен упор на ограниченной роли государства, которому следует вмешиваться как можно меньше в выполнение множества функций малыми общинами и индивидами. На первый взгляд, этот принцип может показаться однозначным, но такое видение по существу обманчиво. Некоторые специалисты справедливо указывают, что он не только многогранный, но и противоречивый 47 , причём его концептуальная неясность имеет обыкновение перетекать в практическую плоскость.

С одной стороны, с его помощью государства-члены в ЕС вооружаются аргументом, который позволяет им противодействовать нежелательному вмешательству со стороны наднациональных институтов. С другой стороны, практика принятия европейских решений становится более усложнённой, запутанной, если не хаотичной. Возникает вероятность того, что государства-члены станут злоупотреблять принципом субсидиарности, что помешает действиям со стороны Союза, которые могут быть необходимы по определённым причинам. Но и наднациональные институты имеют возможность воспользоваться данным принципом не по назначению - «спрятавшись» за него, чтобы ничего не делать в сложной ситуации.

Вопреки желаемому, в ЕС по-прежнему не выработано согласие между государствамичленами, на котором можно было бы выстроить чёткое и ясное распределение компетенций между властными уровнями. Субсидиарность не помогает найти такое согласие - она составляет ширму, позволяющую обходиться без него, но время от времени провоцирует столкновения между акторами, исходящими из разных предпочтений. Поэтому всякую отдельную интерпретацию субсидиарности следует по сути считать политическим актом несмотря на техническую и внешне аполитичную исходную окраску данного концепта.

Когда мы говорим о субсидиарности, то в широком смысле подразумеваем установление пределов, в которых публичная власть имеет право и даже обязана вмешиваться в социальную и экономическую жизнь. Данный принцип действует в двух направлениях. Снизу-вверх - он настаивает, что индивиды и малые общины сами ответственны за выполнение определенных функций. Сверху-вниз - признаётся, что власти более высокого порядка, такие как государство и наднациональные институты, могут вмешаться, чтобы поощрить, стимулировать, отрегулировать или дополнить менее крупные общественные единицы - то есть оказать им содействие ${ }^{48}$.

Принципом субсидиарности, следовательно, регулируются отношения власти в рамках политического порядка. Он способен обретать повышенную значимость в периоды институциональной трансформации регионального интеграционного объединения. Распределение власти согласно данному принципу должно удовлетворять условию сравнительной продуктивности (efficiency), что вызывает известные разночтения: искомую продуктивность можно интерпретировать как эффективность либо как необходимость (то есть обстоятельство, которое делает совершённое действие или причинение вреда извинительным). В то же время у субсидиарности есть и неоспоримое демократическое измерение, которое отражает соображения, относящиеся к степени близости граждан к центрам принятия решений и к праву на самоуправление.

\footnotetext{
${ }^{46}$ Cass D. Z. (1992) he Word That Saves Maastricht? The Principle of Subsidiarity and the Division of Powers within the European Community // Common Market Law Review, vol. 29, issue 6, pp. 1107-1136.

${ }^{47}$ Van Kersbergen K. and Verbeek B. (2007) The Politics of International Norms: Subsidiarity and the Imperfect Competence Regime of the European Union // European Journal of International Relations, vol. 13, issue 2, pp. 224225.

48 Латинский глагол subsidio (помогать) и производное от него существительное subsidium (помощь, содействие).
} 
Сам термин появился, как известно, достаточно давно - в 1931 г., когда он был предложен папой римским Пием ХІ. Субсдиарность в обнародованной тогда теологической трактовке призвана была защитить индивида от наступавшего тоталитаризма. Фашистский режим Бенито Муссолини в Италии оказывал давление на Католическую церковь, добиваясь, чтобы она ограничилась только делами веры, но Пий ХІ отстаивал общественную роль Церкви. Он выступил с энцикликой (открытым письмом) «В сороковой год» ${ }^{49}$ (Quadragesimo Anno), развивающей католическую социальную доктрину, где, в частности, было сказано: «Как не позволено, с целью передачи обществу, забирать у отдельных лиц то, что они могут совершить по собственной инициативе и собственными силами, так в равной мере недопустимо передавать более крупной и значительной организации то, что может быть сделано меньшими и подчинёнными общинами. Ибо всякая общественная деятельность должна по самой своей природе обернуться рукой помощи членам общественного организма, но никак не разрушать и не поглощать таковые».

В теологической версии субсидиарности функциями наделялись надлежащие (не обязательно низшие) органы и уровни - до тех пор, пока они справляются с теми задачами, которые на них возложены. При этом (временное) содействие от уровней более высокого порядка предназначается для восстановления способности надлежащих органов, но не для их замены или долговременного отстранения.

Как видим, идея субсидиарности может трактоваться как в позитивном, так и в негативном ключе. Позитивная идея относится к допустимости или даже необходимости вмешательства более крупного (превосходящего) сообщества в дела сообщества менее крупного (нижестоящего). Негативная идея подразумевает ограничение власти более крупного сообщества относительно менее крупного.

В качестве примера укажем, что в ЕС более высокий властный уровень фактически доминирует в сфере политики защиты окружающей среды, где важнейшие вопросы решаются наднационально, а дополнительные меры регулирования принимаются на национальном уровне. В сфере политики занятости, напротив, ЕС устанавливает лишь минимальные стандарты безопасности и защиты здоровья, а остальное, по большому счёту, оставляет на усмотрение национальных правительств.

Потребность в контроле над соблюдением субсидиарности находится в обратной зависимости относительно меры политизации целей и задач Евросоюза. Чем больше правительства государств-членов, Европейский парламент, Европейский совет и прочие многочисленные политические акторы вовлечены в обсуждение и непосредственную постановку таких задач, тем меньше нужен тщательный анализ соответствия принятого решения требованиям субсидиарности.

Как не устают повторять многие учёные, наблюдатели и политики, все международные организации (и Европейский союз в их числе) подвержены дефициту демократии. Так, по мнению Роберта Даля, одного из основоположников концепции плюралистической демократии, международные организации в принципе не способны обеспечить непосредственное демократическое обсуждение проблем и принятие решений демократическим путём ${ }^{50}$. В то же время, по мнению Кристофера Лорда, если сравнивать ситуацию в ЕС с масштабом демократического дефицита, скажем, в системе Организации

\footnotetext{
${ }^{49}$ Quadragesimo Anno 79 (Encyclical of Pope Pius XI on Reconstruction of the Social order to Our Venerable Brethren, the Patriarchs, primates, Archbishops, Bishops, and Other Ordinaries in Peace and Communion with the Apostolic See, and Likewise to All the Faithful of the Catholic World. Available at: http://w2.vatican.va/content/piusxi/en/encyclicals/documents/hf_p-xi_enc_19310515_quadragesimo-anno.html. Подразумевается сороковой год со времени публикации в 1891 г. Rerum Novarum - энциклики папы Льва XIII. Available at: http://www.unavoce.ru/library/rerum_novarum.html.

${ }^{50}$ Dahl Robert (1999) Can International Organizations Be Democratic? A Skeptic's View // Ian Shapiro and Casiano Hacker-Cordon (eds.) Democracy's Edges, Cambridge, Cambridge University Press, pp. 19-36
} 
Объединённых Наций или в Международном валютном фонде, то Европейский союз смотрится как значительно более демократичное образование ${ }^{51}$. В то же время, оценивая ЕС по более строгим стандартам национальных демократий, политологи находят в нём серьёзный дефицит демократии «на входе» ${ }^{52}$.

Точка зрения, что Европейский союз страдает от дефицита (недостатка, нехватки) демократии, широко распространена. Многие политологи, политики и представители общественности порицают ЕС за этот «недуг», ссылаясь на ощущение существующего разрыва между европейскими нормами и фактическим состоянием дел в интеграционном объединении ${ }^{53}$. Они уверены при этом, что все мы можем или даже должны оценивать многоуровневый Европейский союз, руководствуясь нормами демократической легитимности. Кто-то утверждает, что европейский интеграционный процесс мало совместим с демократией, тогда как его изъяны наносят вред национальным политическим системам. Но даже среди большинства аналитиков, озвучивающих подобные претензии, нет согласия в том, в чём именно состоит такой дефицит и что служит его причиной ${ }^{54}$.

Многие специалисты настаивают при этом, что процесс европейской интеграции необходимо продолжить, чтобы восполнить недостаточность национальной демократии во взаимозависимом мире. Для них демократический дефицит в ЕС связан, скорее, с тем, что ЕС пока ещё недостаточно интегрирован. Действительно, нельзя утверждать, что наднациональная система управления в принципе не может быть демократической. Но нам не известно, способен ли реальный Европейский союз осуществить переход к жизнеспособной демократической многоуровневой политической системе и когда это могло бы произойти в реальности.

В начале своего пути западноевропейское интеграционное объединение было аполитичным и технократическим. Политические черты нарастали в нём по мере углубления интеграции. В последние годы темп политизации ускорился - как реакция на многочисленные кризисы (не только в экономике, начиная с кризиса в еврозоне, но также и в политике упомянем миграционный кризис), с которыми столкнулось европейское интеграционное объединение. Политизация ЕС в наиболее явном виде проявляет себя на национальном уровне, где прибывает популистский экстремизм в социальных движениях, политических партиях и даже в правительствах (назовём в первую очередь такие страны, как Венгрия, Польша и Италия). Взаимосвязи важнейших институциональных акторов европейского уровня - Совета, Комиссии, ЕЦБ и Европейского парламента - тоже носят всё более ярко выраженный политический характер. Важный вопрос, который возникает в связи с подобной многоуровневой политизацией, касается её легитимности.

На раннем этапе европейской интеграции демократическая легитимность в европейском интеграционном объединении опиралась исключительно на национальные парламенты и отталкивалась от того обстоятельства, что они ратифицировали учредительные договоры и что всякое решение по передаче власти Европейскому союзу принималось по их воле и с их согласия. С внесением в основополагающий Договор всё новых поправок, которые

\footnotetext{
${ }^{51}$ Lord C. (2017) An indirect legitimacy argument for a directly elected European parliament //European Journal of Political Research, vol. 56, issue 3, pp. 512-28.

${ }^{52}$ Kröger S. and Friedrich D. (eds.) (2012) The Challenge of Democratic Representation in the European Union, Basingstoke: Palgrave Macmillan.

${ }^{53}$ Fossum John Erik (2016) Democracy and Legitimacy in the EU: Challenges and Options // Arena Working Paper, no 1 (February). URL: https://www.sv.uio.no/arena/english/research/publications/arena-working-papers/2016/wp-116.pdf.

54 У выражения «демократический дефицит» нет чёткого определения. Одним из первых в 1979 г. это выражение для характеристики слабой демократической легитимности Европейского сообщества использовал лейборист Дэвид Марканд. См.: Mény Yves (2002) De la démocratie en Europe: Old Concepts and New Challenges //Journal of Common Market Studies, vol. 41, no. 1, p. 1.
} 
последовательно расширяли круг полномочий институтов ЕС, подобный контур легитимности утратил первоначальную чёткость. Особое значение в этом смысле имел прогрессирующий переход от единогласия к голосованию квалифицированным большинством в Совете министров ЕС. С этим переходом государства-члены, как и их парламенты, лишились права вето при принятии европейских решений, которые их не устраивали.

Последнее, в свою очередь, было многими воспринято как подрыв национальных демократических процессов в государствах-членах, стимулировавший депарламентаризацию политических процессов в ЕС. Государства-члены утратили в демократическом качестве, потому что процесс принятия решений в ЕС негативным образом сказывался на национальных демократических процедурах, причём такой урон не находил компенсации на европейском уровне.

Демократичность и эффективность - два качества политической системы, институтов и процесса принятия решений в ЕС, которыми они должны обладать, чтобы считаться легитимными. Иными словами, они должны отражать волю народа (иметь политическую легитимность «на входе» - input legitimacy) и в то же время способствовать достижению общего блага (легитимность «на выходе» - output legitimacy) ${ }^{55}$. Понятия легитимности «на входе» и «на выходе», впервые применённые при изучении ЕС Фрицем Шарпфом, были позаимствованы из теории политических систем Дэвида Истона ${ }^{56}$.

Разные политические системы в мире, так или иначе, опираются на сочетание легитимности «на входе» и «на выходе». Однако, согласно мнению большинства учёных, на ранних этапах единственной формой политической легитимности, которая была доступна западноевропейскому интеграционному объединению, была легитимность «на выходе».

С точки зрения демократия «на входе» важно участие граждан в принятии решений. Главным образом, но не исключительно, её обеспечивают избрание гражданами своих представителей и их способность привлечь потом этих представителей к ответу. Так как легитимность «на выходе» находится в зависимости от способности институтов и исполнительных органов выдать ожидаемые результаты, то самый простой способ оценить её - сосредоточиться на неких индикаторах функционирования экономики, позволяющих более информативно судить о способности рассматриваемых институтов обеспечить получение искомого. Соответственно, легитимность «на выходе» опирается на успешность политики $\mathrm{EC}^{57}$.

Легитимность «на выходе» чаще всего связывают с тем, как работают в ЕС так называемые немажоритарные институты ${ }^{58}$ - такие как Европейский центральный банк, Европейская комиссия и Суд ЕС. В определении Алека Стоуна Свита и Марка Тэтчера, к немажоритарным институтам относятся органы управления, наделённые некой специализированной публичной властью. Они применяют её, действуя в отрыве от других институтов. Немажоритарные институты не избираются непосредственно населением и не управляются напрямую избранными официальными лицами ${ }^{59}$.

В описании Свита и Тэтчера ${ }^{60}$, у представителей немажоритарных институтов более чёткие и сфокусированные мандаты, чем у избираемых политиков. Немажоритарные институты обычно обязаны объяснять свои действия широкой публике и публиковать

\footnotetext{
${ }^{55}$ Scharpf F. W. (1999) Governing in Europe: Effective and Democratic?, Oxford: Oxford University Press.

${ }^{56}$ Easton D. (1965) A Systems Analysis of Political Life, New York: John Wiley.

${ }^{57}$ Majone G. (1996) Regulating Europe, New York: Routledge; Majone G. (1997) From the positive to the regulatory state: Causes and consequences of changes in the mode of governance //Journal of Public Policy, vol. 17, no 2, pp. 139167.

${ }^{58}$ Majone G. (1998) Europe's Democratic Deficit //European Law Journal, vol. 4, no 1, pp. 5-28.

${ }^{59}$ Sweet Alec Stone and Thatcher Mark (2002) Theory and Practice of Delegation to Non-Majoritarian Institutions //West European Politic, vol. 25, no 1, pp. 1-22. Available at: https://pdfs.semanticscholar.org/6060/b3618b535f60b06353ce10c98870e8ed5842.pdf. ${ }^{60}$ Ibid., p. 19.
} 
соответствующую информацию, а у легислатур имеется власть над ними, включая право производить назначения, получать разъяснения и созывать парламентские слушания.

Легитимность «на выходе», таким образом, поставлена в зависимость от способности наднациональных институтов и исполнительных органов гарантировать получение ожидаемых результатов. Но до тех пор, пока нарастание исполнительных полномочий на уровне ЕС не сопровождается адекватными механизмами политической отчётности, резонны опасения, что платой за усиление европейского управления станет ущербная демократическая легитимность.

Вопрос о том, не страдает ли Европейский союз от дефицита демократии, привлёк к себе особенно пристальное внимание учёных в 1993 г. в связи с решением Федерального конституционного суда Германии по Маастрихтскому договору ${ }^{61}$, в котором понятия дефицита демократии и правовой легитимности (легальности) были чётко разведены. Из него вытекало, что политическая система ЕС может страдать от демократического дефицита, будучи вполне легитимной, а потому требуется выяснить, во-первых, нуждается ли она именно в демократической легитимности и, во-вторых, обладает ли она такой легитимностью на деле или нет.

Идея о том, что для Европейского союза косвенной (непрямой) легитимности достаточно, исходно опиралась на представления неофункционалистов и приверженцев либерального межправительственного подхода. В неофункционализме, в частности, отстаивалась та точка зрения, что каждый новый кризис порождает условия для интеграции всё новых функций на наднациональном уровне. Оправданием для такого рода интегративной динамики служила эффективность институтов и экономические преимущества интеграции. Продвижение интеграции вперёд зачастую описывалось неофункционалистами как ненамеренное следствие ранее принятых мер - как дополнительный шаг, который всякий раз требуется сделать, чтобы закрепить эффективность предпринимаемых мер в меняющихся обстоятельствах. В этом смысле особенно влиятельными оказались соображения Джандоменико Маджоне о ЕС как о «регуляторном государстве», трактовка в категориях принципал-агент, предложенная Эндрю Моравчиком ${ }^{62}$, и описание легитимности «на выходе», которое было дано Шарпфом ${ }^{63}$.

Мажоне считал, что регуляторные органы работают более эффективно, когда они ограждены от политического влияния ${ }^{64}$. По Моравчику, Евросоюз в достаточной мере отвечает требованиям демократии, коль скоро демократическими являются его государствачлены. В частности, при обсуждении проблемы демократического дефицита ЕС постоянно сравнивают с национальным государством, причём при подобном сравнении Европейский союз неизменно проигрывает. Моравчик замечает, что нужно отказаться от сравнения международных организаций с демократическими системами, какими они могут видеться

\footnotetext{
${ }^{61}$ Bundesverfassungsgericht. 1993. "Maastricht Case.” Cases 2134/92 \& 2159/92, Decision of October 12. Судом было принято решение, что обязательства, которые взяла на себя Германия, подписав Маастрихтский договор, не нарушают германскую конституцию. Тем самым было устранено последнее препятствие к его ратификации. Wiegandt M.H. (1995) Germany's International Integration: The Rulings of the German Federal Constitutional Court on the Maastricht Treaty and the Out-of-Area Deployment of German Troops// American University International Law Review, vol. $10, \quad$ no. $\quad 2, \quad$ pp. $\quad 889-916 . \quad$ Available at: http://digitalcommons.wcl.american.edu/cgi/viewcontent.cgi?article=1438\&context=auilr. См. также: Клёмин А.В. (2010) О соотношении национального и европейского права // Актуальные проблемы экономики и права, №2, c. 184-194. Доступно по адресу: http://apel.ieml.ru/storage/archive_articles/9275.pdf.

${ }^{62}$ MoravcsikA. (2002) In Defence of the 'Democratic Deficit': Reassessing Legitimacy in the European Union // Journal of Common Market Studies, vol. 40, no 4, pp. 603-624.

${ }^{63}$ Scharpf, F.W. (1998) Interdependence and Democratic Legitimation // Max Planck Institute for the Study of Societies, Working Paper No. 2, Cologne. Available at: http://www.mpifg.de/pu/workpap/wp98-2/wp98-2.html.

${ }^{64}$ Majone, G. (1997) The Regulatory State and its Legitimacy Problems //Western European Politics, vol. 22, no. 1, p. 4.
} 
только в идеале. Более резонным представляется ему вопрос о том, насколько международные организации приближаются в этом плане к реальному состоянию демократических институтов в развитых странах, которые тоже не без изъяна. То, что политические институты ЕС ограждены от прямого демократического оспаривания их решений, он считал оправданным (квазиоптимальным) ввиду недостатка в понимании политики ЕС со стороны граждан (данные Евробарометра в прежние годы действительно подтверждали, что граждане крайне мало знают о ЕС и к тому же не слишком им интересуются) и как способ помешать доминированию в его решениях особых интересов.

В этом плане некоторую озабоченность вызывала у Моравчика главным образом структура Европейского центрального банка, который менее зависит от политического давления, чем любой национальный центральный банк в мире ${ }^{65}$. Моравчик спорил, что у ЕС нет компетенции в отношении тех сфер экономической политики, которые особенно беспокоят граждан - таких, например, как борьба с безработицей. Отбиваясь от оппонентов, он отстаивал вызывающую довольно большие сомнения позицию, согласно которой «связь между денежно-кредитной политикой и её макроэкономическими последствиями трудно установить» ${ }^{66}$, тогда как бюджетная политика и политика на рынке труда, остающиеся в национальной компетенции, являются «самыми релевантными инструментами для оказания влияния на занятость и экономический рост» ${ }^{67}$. Но нарисованная им таким образом картина входила в вопиющее противоречия с выкладками тех учёных, которые указывали на отсутствие координации между бюджетной и кредитно-денежной политикой как на весьма вероятную причину серьёзнейших проблем в европейской экономике ${ }^{68}$

Для таких авторитетных авторов, как Маджоне, Ганс-Петер Ипсен и Моравчик, решающим в данном смысле был вопрос о том, есть ли в системе ЕС институты, предотвращающие злоупотребление властью со стороны привилегированных корпораций. Если судить только на основании подобного критерия, то европейское интеграционное объединение уже на ранних этапах его существования можно было счесть достаточно демократическим образованием. Консенсуальные формы принятие решений и присутствие в системе большого числа игроков с правом вето (до институциональных реформ 1980-х 1990-х годов) обеспечивали надёжный контроль над теми, кто имел в ней власть. Понятно в то же время, что компенсировать легитимность «на входе» легитимностью «на выходе» в сложных экономических условиях, когда европейским институтам труднее продемонстрировать хорошие результаты своей работы, в любом случае вряд ли было бы возможно.

Скажем, по мнению Мажоне, немажоритарные институты необходимы для эффективного ведения политики, которая в противном случае пострадала бы от действий акторов, движимых электоральными соображениями. Только в вопросах перераспределения доходов, при решении которых кто-то неизбежно выигрывает, а кто-то - проигрывает, необходимо, как он считает, обращаться к мажоритарным (избираемым) институтам ${ }^{69}$. Поскольку у Евросоюза, как он неизменно подчёркивал, всегда была преимущественно

\footnotetext{
${ }^{65}$ Moravcsik A. (2004) Is there a 'Democratic Deficit' in World Politics? A Framework for Analysis // Government and Opposition, vol.39, issue 2, p. 362. Available at: https://www.princeton.edu/ amoravcs/library/framework.pdf.

${ }^{66}$ Moravcsik A. (2006) p. 225. What Can We Learn from the Collapse of the European Constitutional Project? // Politische Vierteljahresschrift, vol. 47, pp. 219-241.

${ }^{67}$ Ibid, p. 226.

${ }^{68}$ Begg I, Hodson D., Maher I. (2003) Economic Policy Coordination in the European Union // National Institute Economic Review, no $183, \quad$ pp. $\quad$ 66-77. URL: http://citeseerx.ist.psu.edu/viewdoc/download?doi=10.1.1.470.9409\&rep=rep1\&type=pdf.

${ }^{69}$ Majone G. (2001) Nonmajoritarian Institutions and the Limits of Democratic Governance: A Political Transaction-Cost Approach // Journal of Institutional and Theoretical Economics (JITE) / Zeitschriftfür die gesamte Staatswissenschaft, vol. 157, no. 1, 18th International Seminar on the New Institutional Economics - The Proper Scope of Government, pp. $57-78$.
} 
регуляторная природа (иными словами, его институты в основном занимаются рыночным регулированием), то они представляют собой, по выражению Маджоне, своеобразную четвёртую ветвь власти. Подобно любому специализированному агентству, европейские институты соединяют в себе экспертизу с выработкой правил и судебной функцией ${ }^{70}$. В подобных институтах-«агентствах», когда они создавались в Европе, по его словам, не было, собственно, ничего нового. Они впервые появились не в Европе, а в США и традиционно играют важную роль в государственном управлении, обеспечивая имплементацию долговременных целей, которых иначе не добиться из-за вероятных неоднократных разворотов в политике правительств, которые сменяют друг друга в результате выборов.

Регуляторную политику, по словам Маджоне, лучше изолировать от стандартного демократического процесса. Эффективность работы регуляторных институтов имеет тенденцию повышаться при низком уровне политизации европейских вопросов в национальных рамках. Чтобы подобная система хорошо функционировала, по его рецепту, на европейский уровень нежелательно передавать в существенных масштабах решение вопросов, предполагающих перераспределение финансов от одной страны к другой, потенциал политизации которых слишком высок.

Маджоне вторил Ипсен. Последний называл Европейский союз «ассоциацией функциональной интеграции», которая была создана специально, чтобы справиться с последствиями либерализации в европейской экономике. Этой целью, по его словам, оправдывалась активность ЕС в ряде функциональных областей и - в то же время ограничение компетенций ЕС тем, что необходимо, чтобы справиться с условиями экономической взаимозависимости ${ }^{71}$.

Между тем мировой финансовый кризис 2008 г. и его тяжёлые последствия для Европы привели как раз к дополнительному расширению компетенций Евросоюза в экономическом управлении, что мы ещё будем обсуждать на страницах этой публикации. Его компетенции, наряду с рыночным регулированием, теперь распространились также на (пере)распределение ресурсов и обеспечение стабильности в экономике. С подобным расширением масштаба своей власти Европейский союз в вопросах обеспечения демократии не должен более полагаться исключительно на легитимность государств-членов. Его следует легитимировать наднациональными средствами демократического контроля, которые Европейский парламент, однако, не в состоянии обеспечить в полной мере, так как он представляет не единый народ, а множество народов интегрированной части Европы. Коль скоро у Союза отсутствует наднациональный источник демократической легитимации, нарастание его компетенций без учёта данного фактора скорее не усиливает, а ослабляет его легитимность.

В настоящее время на европейском уровне действия национальных министров в Совете и национальных чиновников в многочисленных трансправительственных комитетах выпадают и из сферы контроля национальных парламентов. Национальные министры, голосуя в Совете, национальные чиновники, прорабатывая европейские решения в Комитете постоянных представителей или в рабочих группах Совета, как и чиновники в Комиссии, когда они разрабатывают и имплементируют европейское законодательство, обособлены от национальных парламентов куда в большей степени, чем те же министры национальных кабинетов или чиновники, когда последние задействованы в процессах управления на национальном уровне. Поэтому, принимая решения в Брюсселе, они могут игнорировать свои

\footnotetext{
${ }^{70}$ Majone G. (1998) Europe's "Democratic Deficit”: The Question of Standards //European Law Journal, vol. 4, no1, March, p.15.

${ }^{71}$ Ipsen H-P. (1993) Zur Exekutiv-Rechtssetzung in der Europaeischen Gemeinschaft //P. Badura and R. Scholz (eds.) Wege und Verfahren des Verfassungslebens. Festschrift fuer Peter Lerche. Muenchen: Beck; Ipsen, H-P. (1973) Über Supranationalität //Europäisches Gemeinschaftsrecht in Einzelstudien, Baden-Baden: Nomos, 1984, pp. 97-112.
} 
национальные парламенты ${ }^{72}$. Отсюда вывод, что европейская интеграция действительно ослабила власть национальных парламентов и укрепила положение управленческого персонала разных уровней.

Тем не менее, к положительным заключениям касательно демократических качеств системы ЕС приходят не только сторонники неофункционализма и традиционного межправительственного подхода, но и теоретики делиберативной демократии ${ }^{73}$. Это может вызывать некоторое удивление, если учесть, что для последних в дизайне политических институтов в принципе важно, насколько эти институты обеспечивают осмысленное и эффективное участие граждан в управлении. Тем не менее, многие теоретики данного профиля демократию в ЕС называют жизнеспособной, усматривая наличие процедур, которые позволяют обсуждать и оценивать все уместные доводы в пользу или против определённого европейского решения. При этом они считают второстепенным вопрос, все ли без исключения граждане фактически принимают участие в подобных обсуждениях.

Решения в ЕС и в самом деле формируются большим числом акторов: это европейская бюрократия, национальные правительства, европейский и национальные парламенты, многочисленные группы интересов. Все они привносят в европейские переговоры различные заслуживающие внимания аргументы. Кроме того, по словам Герарда Деланти, приверженца делиберативного подхода, «Европейский союз, как многоуровневая политическая система, и национальное государство находятся в состоянии совместной эволюции. Нельзя было бы просто утверждать, что одно действует в отношении другого. По его оценке, оппозиция национального государства и европейской политии - это ложная дихотомия. Многое из европейского заложено уже в национальной традиции, и именно из такой традиции и возник импульс к развитию европейской интеграции» ${ }^{74}$.

Данную мысль развивает и проясняет автор теории делиберативной демократии немецкий философ Юрген Хабермас. В своей книге «Кризис Европейского союза: ответ» он отдаёт должное институту европейского национального государства. Хабермас подчёркивает, что государства являют собой долговременное достижение, которое необходимо сохранить, тогда как взгляд на ЕС как на (пока ещё) несовершенную федеративную республику, по его мнению, в корне порочен. Если усматривать в Европейском союзе продолжение демократического проекта «усмирения» государственной власти и придания ей более демократических форм, то европейскую демократию, как он полагает, нельзя отрывать от её национально-государственного основания. Пока национальные государства продолжают выполнять свою роль как гаранты закона и свободы, утраты легитимности с учреждением политического порядка за пределами национальных границ не происходит.

Нормативное значение демократии предполагает, что политические возможности могут быть расширены за пределы национальных границ, когда того требует решение задачи контроля политическое повестки. Отсюда значимость ЕС как системы, основанной на праве. Но вместе с тем отличительной чертой европейского интеграционного процесса является то,

\footnotetext{
${ }^{72}$ Follesdal A., Hix S. (2006) Why There is a Democratic Deficit in the EU: A Response to Majone and Moravcsik //Journal of Common Market Studies, vol. 44, no 3, pp. 533-562. Available at: https://onlinelibrary.wiley.com/doi/pdf/10.1111/j.1468-5965.2006.00650.x.

73 Делиберативная демократия подразумевает процесс принятия решений, основанный на обмене разными доводами (на аргументировании). Он отличается от обмена обязательствами, нацеленного на достижение компромисса, который выгоден всем сторонам (от ведения торгов) ${ }^{73}$. Институциональными требованиями делиберации в международной организации выступают транспарентность и инклюзивность при принятии решений, а также требование логически обосновать каждое принимаемое решение. См.: Линде А.Н. (2015) Делиберативная демократия как направление в современной теории демократии: анализ основных подходов // Проблемный анализ и государственно-управленческое проектирование, том 8, с. 52-58.

${ }^{74}$ Delanty G. (2007) Europeanization and Democracy: The Question of Cultural Identity // J. DeBardeleben \& A. Hurrelmann (eds.) Democratic Dilemmas of Multilevel Governance: Legitimacy, Representation and Accountability in the European Union, Basingstoke: Palgrave, p. 86.
} 
что он разворачивается между государствами, в которых управление основывается на национальной конституции.

В то же время Хабермас резко критикует в своей новой работе МВФ, Европейскую комиссию и ЕЦБ - за то, как разрешались ими проблемы еврозоны в ходе кризиса суверенных долгов. Как он пишет в данной связи, в борьбе с глобальными финансовыми рынками Евросоюз деградировал, впав в допотопную политику с позиции силы и диктуя свои условия неплатёжеспособным членам еврозоны ${ }^{75}$.

В статье, которая непосредственно адресуется к утверждениям Маджоне и Моравчика, Фоллесдал и Хикс подходят к проблеме по-другому. Они указывают на то, что демократический дефицит возникает как раз потому, что политика регулирования, которую проводят наднациональные институты, не является нейтральной, а подразумевает перераспределение. Оно ведётся как между государствами, так и между группами интересов внутри отдельных государств ${ }^{76}$. Обсуждаемые в Европе решения здесь видятся в том, чтобы перейти к прямым выборам председателя Европейской комиссии и передать на европейский уровень ключевые национальные компетенции (в фискальной области, в области внешней политики и политики безопасности). Однако напомним, что, как замечал в своё время Франк Декер, при передаче компетенций на европейский уровень его наднациональные характеристики зачастую не находят отзыва в общественной базе - среди партий и избирателей ${ }^{77}$.

По мнению Хикса и Фоллесдала, главным препятствием к развитию демократии на европейском уровне является отсутствие там до сих пор узнаваемой парламентской оппозиции. Роль таковой они считают особенно значимой. Ведь с появлением оппозиции у европейских избирателей оформились бы и новые варианты европейской политики относительно принятой, которым они могли бы отдать предпочтение, а также возможность «наказать» евродепутатов, недостаточно прислушивающихся к настроениям рядовых европейцев. Их идея состоит в том, что с нарастанием градуса политического соревнования на уровне ЕС избиратели будут в большей мере в курсе того, чем занимаются депутаты Европейского парламента, и ко времени следующих выборов в ЕП смогут действовать на них более осознанно. Хикс и Фоллесдал не отрицают отсутствия европейского демоса в современных условиях, но выражают надежду, что с распространением демократических практик возникнут условия, при которых европейский демос сможет, наконец, появиться.

Но подобные предложения критикует Ив Мени, констатируя, что «наихудшей тактикой стало бы воспроизведение средствами имитации правил и практик, существующих на национальном уровне. ... Как показывает опыт Европейского парламента, это самый верный способ добиться разочарования» ${ }^{78}$. По его мнению, главной задачей Европейского союза является открытие новых парадигм, правил и институтов, а вовсе не дублирование старых, т.е. национальных.

\footnotetext{
${ }^{75}$ Habermas Jürgen (2012) The Crisis of the European Union: A Response / tr. by Ciaran Cronin, Cambridge, UK: Polity Press.

${ }^{76}$ Follesdal, A., Hix, S. (2006). Why there is a democratic deficit in the EU: A response to Majone and Moravcsik // Journal of Common Market Studies, vol. 44, no 3, pp. 533-562.

${ }^{77}$ Decker F. (2000) Governance Beyond the Nation-state. Reflections on the Democratic Deficit of the European Union // Journal of European Public Policy, vol. 9, p. 261.

${ }^{78}$ Meny Y. (2002) De la democratieen Europe: Old Concepts and New Challenges // Journal of Common Market Studies, vol.41, no 1, p. 10 .
} 
Другие учёные - например, Вольфганг Штреек и Филипп Шмиттер ${ }^{79}$, Стефан Либфрид и Пол Пирсон ${ }^{80}$ - смотрели на ту же проблему по-своему. В описании Либфрида и Пирсона, в ЕС возникла «многоуровневая, весьма фрагментированная система, в которой политика 'развивается', оставаясь вне надёжного контроля единой политической власти» ${ }^{81}$. Они считали, что проблема заключается, прежде всего, в игнорировании властями Европейского союза идей, отстаиваемых политиками левого центра, что открывает дорогу в ЕС ничем не ограниченной капиталистической конкуренции. В контексте обсуждения «социальной Европы» эти авторы, в свою очередь, справедливо указывали, что политика ЕС в большей мере сосредоточена на негативной интеграции, которая устраняет торговые барьеры и национальные ограничения для свободы передвижения товаров, услуг, людей и капитала. Вместе с тем ЕС относительно слаб в вопросах позитивной интеграции, т.е. в вопросах правовой гармонизации и перенесении ограничивающего рыночные свободы регулирования на европейский уровень.

Свободная конкуренция на едином рынке, по их оценке, ставит национальные правительства и профсоюзы в государствах-членах в сложную, неблагоприятную ситуацию. Она приводит к снижению налогов, социальных выплат, отмене трудовых гарантий, к которым прибегают отдельные правительства, чтобы привлечь на национальный рынок больше инвесторов и иностранных компаний и таким образом сравняться с другими странами в конкурентном отношении. Либфриду и Пирсону вторит Фриц Шарпф, который настаивает, что самым важным в демократической системе является удержание баланса между рыночной либерализацией и социальной защитой. Таким образом, политические институты, в социально-демократической трактовке, призваны корректировать мощь сконцентрированного богатства, накапливающегося в капиталистических экономиках. Но наиболее влиятельные международные институты (включая Европейский союз) односторонним образом сосредоточены на либерализации торговли, что подрывает политику перераспределения и регуляторную защиту национального уровня, провоцируя «гонку на дно» и деградацию в плане социальных стандартов.

На самом деле для многоуровневой системы Европейского союза не может быть одного идеального, раз и навсегда выверенного рецепта, позволяющего поделить суверенитет между властными уровнями, как отсутствует для неё и признанный нормативный баланс централизации и децентрализации. При этом с 2010 года, когда начался европейский кризис суверенных долгов, большинство специалистов согласились в том, что Европейскому союзу не хватает легитимности, с какой бы стороны её ни рассматривать ${ }^{82}$.

Легитимность подобной системы, как представляется, больше зависит от норм, институтов и механизмов, при содействии которых граждане ведут между собой переговоры, а правительства добиваются согласия, чтобы установить, но затем вновь поменять роль каждого из сосуществующих политических полей83. Поэтому для её анализа особенно хорошо подходит концепт сквозной легитимности (throughput legitimacy). Он удачно дополняет более традиционные подходы к показателям функционирования политической системы

\footnotetext{
${ }^{79}$ Steeck W. and Schmitter P. (1991) From National Corporatism to Transnational Pluralism: Organized Interests in the Single European Market // Politics and Society, vol. 19, no 2, pp.133-164.

${ }^{80}$ Leibfried St. and Pierson P. (1995) Semisovereign Welfare States: Social Policy in a Multitiered Europe // St. Leibfried and P. Pierson (eds) European Social Policy: Between Fragmentation and Integration, Washington, DC: The Brookings Institution, pp. 43-77.

${ }^{81}$ Pierson Paul and Leibfried Stephan (1995) The Dynamics of Social Policy Integration // Stephan Leibfried and Paul Pierson (eds.) European Social Policy: Between Fragmentation and Integration, Washington D.C.: The Brookings Institution, pp. 432-466.

${ }^{82}$ Tsoukalis L. (2016) In Defense of Europe, Oxford: Oxford University Press.

${ }^{83}$ Howse R., Nicolaidis K. (2001) Legitimacy and Global Governance: Why Constitutionalizing the WTO Is a Step Too Far // Porter R. B. et al. (eds.) Efficiency, Equity, and Legitimacy: The Multilateral Trading System at the Millenium, Washington, D.C: Brookings Institution Press, pp. 227-252.
} 
Европейского союза - на её «входе» (запросы и потребности граждан) и на «выходе» (решения и действия властей $)^{84}$. Идея сквозной легитимности сосредоточена на качестве процессов управления, включая их полезное действие, подотчётность, транспарентность, инклюзивность и открытость для консультаций с представителями групп интересов ${ }^{85}$.

Идея сквозной легитимности связана с обоснованием жизнеспособности системы, опирающимся на определение качества протекающих в ней процедур ${ }^{86}$. Возможны два её подвида:

1) легитимность, относящаяся к демократической нормативной подотчетности (демократические процедуры);

2) легитимность, связанная с процедурами, ориентированными на результат (достижение общего блага) $)^{87}$.

Дефицит демократии в Европейском союзе связан, как подтверждает вышеизложенное, в основном со сложностями укрепления легитимности институтов ЕС «на входе». Суть его в данном случае состоит в усилении исполнительной власти и в одновременном ослаблении парламентского контроля, в частности контроля со стороны национальных парламентов. Подобное положение дел усугубляется «исполнительным федерализмом» ${ }^{88}$. В приложении к ЕС исполнительный федерализм подразумевает, прежде всего, что если наднациональные исполнительные компетенции Союза и коэкстенсивны его законодательным компетенциям, то, в согласии с принципом субсидиарности, исполнение наднациональных норм по преимуществу отнесено на национальный властный уровень. ЕС вмешивается в процесс только в тех случаях, когда государствам-членам не удаётся обеспечить единообразные условия для имплементации европейского законодательства и когда, соответственно, такая имплементация лучше обеспечивается на уровне Союза (см. статью 5.3 Договора о Европейском союзе).

Продвижение интеграции на базе ЕС в правовом смысле выражается в накоплении им полномочий, полученных на основании межгосударственных договоров. В ранние годы существования европейского интеграционного объединения наднациональные институты пользовались такими полномочиями, опираясь на «разрешительный консенсус» (permissive consensus) со стороны граждан ${ }^{89}$. С помощью этого термина описывалась специфика поддержки европейских сообществ, которая была широко распространена среди массовой публики, что отражали и опросы общественного мнения того времени. Такая поддержка не

\footnotetext{
${ }^{84}$ Schmidt V. (2010) Democracy and Legitimacy in the European Union Revisited. Input, Output and Throughput // KFG Working Paper, no. 21, 31 p. $\quad$ Available $\quad$ at: berlin.de/kfgeu/kfgwp/wpseries/WorkingPaperKFG_21.pdf.

${ }^{85}$ Schmidt V. (2016) Reinterpreting the Rules "by Stealth" in Times of Crisis: The European Central Bank and the European Commission // West European Politics, vol. 39, no. 5, pp. 1032-1052. Available at: http://blogs.bu.edu/vschmidt/files/2016/09/Schmidt-WEP-reinterpreting-the-rules-by-stealth-final.pdf.

${ }^{86}$ Bekkers V., Edwards A. (2007) Legitimacy and Democracy: A Conceptual Framework for Assessing Governance Practices // V. Bekkers, G. Dijkstra, A. Edwards and M. Fenger (eds.) Governance and the Democratic Deficit: Assessing the Democratic Legitimacy of Governance Practices, Aldershot, Hampshire: Ashgate, pp. 35-60.

${ }^{87}$ Lieberherr E. (2013) The Role of Throughput in the Input-Output Legitimacy Debate: Insights from Public and Private Governance Modes in the Swiss and English Water Sectors// Conference Paper. First International Conference on Public Policy. Panel 39: The New Policies of Privatization.

${ }^{88}$ Schütze R. (2010) From Rome to Lisbon: 'Executive federalism' in the (new) European Union //Common Market Law Rreview, vol. 47, no 5, pp. 1385-1427. См. также: Fabbrini F. (2015) From Executive Federalism to Executive Government: Current Problems and Future Prospects in the Governance of the EMU// F. Fabbrini, E.H. Ballin \& H. Somsen (eds.) What form of Government for the European Government and the Eurozone?, Bloomsbury: Hart Publishing, pp. 289-306; Dann Philipp (2004) Parlamente im Exekutiv föderalismus, Berlin: Springer.

${ }^{89}$ Lindberg L.N. and Scheingold S.A. (1970) Europe's Would-Be Polity: Patterns of Change in the European Community, Englewood Cliffs, N.J.: Prentice-Hall, p. 41. См. также: Семененко И., Прохоренко И. (2015) От проекта элит к массовой политике: вызовы политизации европейской интеграции // Мировая экономика и международные отночения, № 7, с. 29-40.
} 
отличалась глубиной. Её можно охарактеризовать как благожелательную, но поверхностную незаинтересованность, при которой население европейских стран охотно доверяло развитие европейской интеграции элитным кругам, но само мало ею интересовалось.

Со временем ситуация изменилась, и на смену «разрешительному консенсусу» пришло «ограничивающее несогласие» (constraining dissensus), которое утвердило роль общественного мнения в европейской политике, но одновременно поставило легитимность Европейского союза под вопрос ${ }^{90}$ и стало сдерживать дальнейшее углубления интеграции. Принимаемые в ЕС решения (в том числе в области валютного союза, но также в сфере защиты прав человека, во внешней политике) с годами обрели большую остроту в национальном контексте отдельных стран, стали предметом острого общественного обсуждения. Уход в прошлое «разрешительного консенсуса» отразило падение явки на выборах в Европейский парламент (она снизилась с 62\% в 1979 г., когда европейские выборы состоялись впервые, до 43\% в 2014 г. (следующие выборы в ЕП ожидаются в мае 2019 г.).

В плане легитимности «на входе» основополагающий Договор заложил двойную структуру для Европейского союза, при которой Европейский парламент и национальные парламенты осуществляют прямую и косвенную функцию его политической легитимации соответственно. С целью укрепления демократии на европейском уровне с внесением изменением в договорную базу интеграции происходило укрепление наднационального парламента интеграционного объединения, который за долгие годы претерпел эволюцию - от слабой консультативной ассамблеи к Европейскому парламенту, избираемому на основе прямых выборов и наделённому законодательными полномочиями. Но, несмотря на подобные усилия, дефицит демократии, связанный с недостаточным доверием к институтам ЕС со стороны граждан, преодолеть не удалось.

Как показывают исследования, между предпочтениями избирателей, демонстрируемыми на европейских выборах, и тем, какие решения принимает ЕП, нет тесной связи. Ключевая проблема состоит в том, что выборы в ЕП - это выборы «второго порядка», не имеющие приоритетной значимости для европейцев, что негативно отражается на степени заинтересованности избирателей как в самих выборах, так и в той политике, которая проводится на европейском уровне. Результатом и становится относительно низкая явка избирателей на европейских выборах. Электорат до сих пор руководствовался на этих выборах национальными внутриполитическими соображениями, а не исходил из своего отношения к проблемам интегрированной Европы непосредственно. При этом нормативное качество демократических форм, демонстрируемых в Европейском союзе, вызывает многочисленные сомнения, коль скоро вне национального государства не существует социальных и культурных условий, на которые могут полагаться традиционные формы демократии.

Европейский парламент с годами получил широкие полномочия по демократическому контролю в отношении Комиссии. Их взаимоотношения в итоге стали больше напоминать то, что мы видим в парламентских системах, существующих на национальном уровне в большинстве государств-членов. В то же время на прочие институты ЕС с исполнительными полномочиями это не распространяется. Хотя члены Европейского совета, Совета министров ЕС или Европейского центрального банка должны появляться перед ЕП, чтобы отвечать на вопросы или представлять евродепутатам свои отчёты, следует признать, что такие механизмы не составляют полноценной подотчётности (отсутствуют какие-либо санкции в отношении действий или решений этих институтов, могущих быть расцененными как недопустимые).

В целом ни в каком смысле нельзя было бы утверждать, что исполнительная власть европейского уровня избирается Европейским парламентом. В частности, Комиссия не

\footnotetext{
${ }^{90}$ Schmidt V.A. (2006) Democracy in Europe: The EU and National Polities, Oxford: Oxford University Press. O завершении периода «разрешительного консенсуса» см. также: Deutsch F. (2006) Legitimacy and Identity in the European Union: Empirical Findings from the Old Member States // Ireneusz Pawel Karolewski, Viktoria Kaina (eds.) European Identity. Theoretical Perspectives and Empirical Insights, Münster: LIT, pp. 149-178.
} 
избирается, но назначается Европейским советом (для этого ЕП должен предварительно утвердить её состав). Впрочем, при назначении главы ЕК в 2014 г. (им стал Жан-Клод Юнкер) впервые была использована процедура «Spitzenkandidaten», или лидирующего кандидата. На основании этой процедуры им мог стать только заранее определённый кандидат от политической группы в ЕП, получившей наибольшее число голосов избирателей на европейских выборах (такой группой в 2014 г. стала Европейская народная партия, назвавшая Юнкера своим кандидатом). Эта процедура отталкивается от положения Лиссабонского договора, которое при назначении Европейским советом главы Комиссии не более чем требует учесть результаты состоявшихся выборов в ЕП. Данное положение не подразумевает непосредственно, что Европейский совет лишается своей традиционной прерогативы по определению того, кто будет главой ЕК.

Европейский парламент, единственный представительный орган $\mathrm{EC}$, который избирается в ходе прямых выборов, совместно с Советом принимает в Европейском союзе законодательные решения. В рамках обычной законодательной процедуры, применяемой примерно в 90\% случаев, у обоих институтов равные полномочия. Но в вопросах, которые касаются Экономического и валютного союза, которому и посвящена эта книга, у Европейского парламента власти как раз ощутимо меньше.

В данной сфере обычная законодательная процедура применима лишь на основании:

$\diamond$ статьи 121.6 Договора о функционировании Европейского союза (ДФЕС) - по процедурным аспектам многостороннего наблюдения за национальными бюджетами и курсами экономической политики;

$\diamond$ статьи 129.3 - для изменения некоторых положений Статута Европейской системы центральных банков и Европейского центрального банка; и

$\diamond$ статьи 133 ДФЕС - по валютному законодательству.

Во всех прочих случаях ЕП играет исключительно консультативную роль либо его просто информируют о принимаемых решениях, а там, где речь идёт о решениях, касающихся исключительно еврозоны, и этого зачастую не наблюдается в ощутимой степени.

Функция демократического контроля, которую ЕП выполняет на основании статьи 14.1 ДЕС, направлена преимущественно на Европейскую комиссию. Национальные министры в Совете и главы национальной исполнительной власти в Европейском совете подотчётны своим национальным парламентам. Полномочия этих парламентов в соответствующих вопросах определяются национальной конституцией, т.е. различаются от страны к стране. Каждое государство ЕС, в конечном счёте, отдаёт предпочтение сохранению собственной демократической легитимности. У Европейской комиссии отсутствуют политический или демократический мандат, чтобы успешно посредничать между различными странами с их не совпадающими или даже конфликтующими, но при этом легитимными интересами.

Вопрос о легитимности институтов ЕС, как мы видим, до сих пор не получил однозначной трактовки. Если исходить из умозаключений по аналогии, то их легитимность должна находить подтверждение в указаниях на то, что эти институты подчиняются тем же принципам, что лежат в основе легитимности государств-членов. При этом обычно подразумевается, что такие принципы сами по себе полностью обоснованы, что они адекватным образом соблюдены во всех государствах-членах (что не всегда соответствует действительности) и что возможность их применения в Европейском союзе в целом не вызывает сомнений. В институтах ЕС нужно в таком случае искать элементы структурного сходства или функциональной эквивалентности с соответствующими национальными институтами. При такой (наднациональной) модели легитимации ЕС в фокусе его легитимности должны лежать государство-подобные черты. $\mathrm{EC}$ следует признать легитимным, если и когда европейские и национальные институты более или менее схожи между собой. 
Если же придерживаться логики дополнительности, то подтверждать легитимность ЕС нужно, напротив, выделяя и подчёркивая различия между европейскими и национальными институтами. Здесь исходным оказывается предположение, что особые возможности тех и других позволяют им удачным образом дополнять друг друга. В данном случае необходимо предпослать каждому из уровней управления особые функции, которые больше подходят институтам данного уровня (функциональная модель).

Ни тот, ни другой из этих двух подходов не задаёт чёткой иерархии между двумя уровнями управления (национальным и европейским). Но по факту в Европейском союзе в большинстве случаев приоритет отдаётся национально-государственному уровню. Легитимность ЕС в таком случае следует признать укоренённой в том обстоятельстве, что он контролируется государствами-членами и выступает не более чем инструментом проводимой ими политики (межправительственная модель). Согласно подобной логике, легитимность европейских институтов «на входе» обеспечивается до тех пор, пока компетенции ЕС очевидным образом делегируются ему национальными представителями, и они же приводит их в действие исключительно под своим полным и постоянным контролем.

Сегодня демократия считается абсолютной ценностью, и на неё обычно указывают как на самую важную основу легитимной власти ${ }^{91}$. Для теорий демократической легитимности особенно важен упор как раз на вводные параметры общественных требований. Институты представительной демократии и прямой демократии позволяют гражданам совершать «вход» в политический процесс. Эти институты наделяют избирателей правом определять своих представителей, а референдумы дают гражданам право решать, какую политику следует проводить. В каждом государстве-члене граждане периодически избирают национальных парламентариев, а в некоторых случаях также и президентов. В каждом из государств-членов, за исключением Германии и Бельгии, возможно также (или даже необходимо в определённых случаях) проведение национальных референдумов.

В ЕС граждане избирают своих представителей в ЕП в ходе прямых выборов, а также косвенным (непрямым) образом представлены в Совете и Европейском совете представителями национальных правительств, которые несут ответ перед национальными парламентами и гражданами. Если государства-члены сохраняют высшие полномочия в многоуровневой системе, то демократический контроль в её рамках может быть передан национальным парламентам ${ }^{22}$, власть которых в многоуровневой системе Европейского союза необходимо укрепить.

В рамках наднациональной модели его следовало бы передать наднациональному парламенту - ЕП. Более сложной следует признать промежуточную ситуацию, возобладавшую в области ЭВС, при которой государства-члены сохраняют определённую степень автономии, но на деле свобода их действий сильно ограничена наднациональными рамками и транснациональным взаимодействием.

Важным, хотя и недостаточным, шагом вперёд в осознании существующей проблемы демократической легитимности институтов Экономического и валютного союза стал уже упоминавшийся выше Доклад пяти председателей. В нём признаётся, что, для еврозоны, если она должна не только выжить, но и успешно развиваться в экономическом отношении, необходимо, чтобы в ней, как и в Европейском союзе в целом, заработали более адекватные механизмы обеспечения легитимности и политической отчётности. В Докладе были предложены такие конкретные меры, как укрепление (национального) парламентского контроля в рамках Европейского семестра, наращивание сотрудничества между Европейским

\footnotetext{
${ }^{91}$ Ferrin M. and Kriesi H. (eds.) (2016) How Europeans View and Evaluate Democracy, Oxford: Oxford University Press.

${ }^{92}$ Crum B. (2018) Parliamentary accountability in multilevel governance: what role for parliaments in post-crisis EU economic governance? //Journal of European Public Policy, vol.25, no 2, pp. 268-286.
} 
парламентом и национальными парламентами и повышение статуса Еврогруппы, однако в то же время предложенный в нём подход страдает ограниченностью 93 .

Во-первых, предлагаемые реформы в основном ограничиваются только еврозоной, тогда как с проблемой демократической легитимности сталкивается и ЕС в целом. Во-вторых, проблема демократической легитимности в данном случае сводится к недостаточной подотчётности, составляющей лишь одну её часть, при игнорировании того обстоятельства, что в политической системе ЕС не обеспечены условия для политической конкуренции и нет возможности для смены политического курса на основании результатов европейских выборов.

Чаще всего причину демократического дефицита в системе Европейского союза или даже его усугубления усматривают в том, что полномочия передаются с национального на европейский уровень, но без установления на европейском уровне соответствующего и адекватного демократического контроля. Отсюда выводятся два следствия: во-первых, неспособность партий на европейском уровне контролировать управляющие органы ЕС и, вовторых, неспособность ЕП служить выразителем воли граждан Европы ${ }^{94}$.

Мы получаем картину, в которой европейская интеграция привела к усилению исполнительной власти и ослаблению национального парламентского контроля. При этом Европейский парламент не может обеспечить демократический контроль того же уровня, что и национальные парламенты. Это служит не только проявлением его слабости в сравнении с представителями национальных правительств, заседающими в Совете, но и следствием того, что в силу характера европейских выборов у европейских институтов отсутствует подлинно европейский политический мандат. В Европейском союзе всякому переносу демократических институтов на европейский уровень препятствует проблема отсутствия европейского демоса ${ }^{95}$. Из-за того, что институты ЕС относительно молоды, а население ЕС гетерогенно в культурном отношении, из-за сосуществования множества национальных языков и отсутствия общей публичной сферы европейская идентичность остаётся хрупкой, отсутствует выраженное ощущение общности политической судьбы. Приходится согласиться с тем, что всё это подрывает легитимность демократических решений, которые принимаются на уровне ЕС.

Большинство из институциональных акторов, вовлечённых в многоуровневое европейское управление, не избираются гражданами, от имени которых они якобы действуют, и видимая связь с предпочтениями граждан у них отсутствует. Даже если некоторые элементы европейской демократии «на входе» и могут быть при этом установлены, сложность и запутанность процессов в многоуровневой системе в целом не позволяют вполне гарантировать подотчётности тех, кто принимает в ней решения.

Дополнительные деликатные вопросы возникают в связи с выполнением функции исполнительной власти в рамках ЭВС. Это связано с той доминирующей ролью, которую в разрешении проблем, вызванных кризисом в еврозоне, разразившимся в 2010 г., взял на себя межправительственный Европейский совет. При этом он решительно вышел за пределы привычных понятий и доктрин европейской экономической политики. Именно Европейский совет укрепил экономическую опору ЭВС, добиваясь повышенного качества в координации национальных курсов экономической политики, и усилил механизмы достижения стабильности в еврозоне, используя жёсткие бюджетные правила для национальных экономик. В числе прочих шагов, члены Европейского совета (лидеры национальной исполнительной власти) договорились между собой о внесении изменения в Лиссабонский

\footnotetext{
${ }^{93}$ О Докладе дополнительно см.: Saccomanni F. (2015) The Report of the Five Presidents: A Missed Opportunity // Documenti IAI, no 15, 14 July. Available at: http://www.iai.it/sites/default/files/iai1514.pdf.

${ }^{94}$ Mair P. and Thomassen J. (2010) Political Representation and Government in the European Union //Journal of European Public Policy, vol. 17, no. 1, pp. 20-35.

${ }^{95}$ Новикова О.Н. (2005) «Дефицит демократии» в ЕС: основные направления критического анализа проблемы (обзор) // Актуальные проблемы Европы, № 4, с. 79-104.
} 
договор (добавив новый параграф в статью $136^{96}$ ) и о подписании двух дополнительных соглашений вне правовых рамок $\mathrm{EC}^{97}$.

Напомним, что, как коллективный институт, Европейский совет не подлежит демократическому контролю в достаточной мере. Входящие в Европейский совет главы правительств стран-участниц подконтрольны своим национальным парламентам поодиночке, но не совместно. Европейский парламент осуществляет демократический контроль в отношении Комиссии, но у него нет сопоставимых полномочий, которые действовали бы в отношении Европейского совета.

Обратим также внимание: во время кризиса в еврозоне Европейский парламент, по большому счёту, вообще не участвовал в принятии важнейших решений, которые касались новой архитектуры управления ею. Таким образом, принятие соответствующих решений за закрытыми дверями в Европейском совете не сопровождалось парламентскими дебатами. Европейский парламент не имел отношения и к вопросам предоставления помощи особо пострадавшим от кризиса странам ЕС, которыми занимались МВФ, Комиссия ЕС и ЕЦБ. Впрочем, в двух докладах, не имеющих обязательной силы, ЕП осудил «отсутствие должного наблюдения и в целом демократической отчётности» наряду с негативными социальными последствиями из-за недостатка «надлежащей оценки воздействия» на граждан - такими, как урезание финансирования в сфере здравоохранения, рост безработицы, миграция молодёжи и распространение бедности ${ }^{98}$.

Если подводить предварительный итог, то мы видим, что в академической литературе по вопросу о дефиците демократии в ЕС сложились две противоположные точки зрения. Позиция большинства (разделяемая автором настоящей работы) сводится к тому, что он существует, поскольку процесс европейской интеграции пошёл таким путём, который привёл к явному снижению способности политической власти в Европе справляться с вызовами глобального капитализма демократическими средствами ${ }^{99}$. В последние годы с таким мнением спорить всё труднее, но ранее немало авторов выражало несогласие с ним, в свою очередь, выдвигая достаточно изощрённые аргументы.

По мнению последних, в наднациональном режиме Евросоюза соответствие требованиям демократии должно достигаться иными способами, нежели того требует мажоритарная демократическая модель - а именно, сочетанием легитимности «на выходе» и процедурной легитимности. Как полагал, к примеру, Моравчик, претензии Европейского союза на наличие у него достаточной демократической легитимности вполне оправданны. Ведь результаты проводимой им политики формулируются в ответ на запросы, которые поступают от демократических государств-членов, и необходимые решения определяются ими же в процессе переговоров ${ }^{100}$.

\footnotetext{
${ }^{96}$ Поправка вступила в силу с 1 мая 2013 г., позволив правительствам (исполнительной власти) государств еврозоны учредить постоянный механизм финансовой поддержки (bail-out mechanism) - Европейский механизм стабильности, создание которого уже нельзя было бы оспорить в судебном порядке.

${ }^{97}$ Подробнее см.: De Witte B. (2011) The European Treaty Amendment for the Creation of a Financial Stability Mechanism // SIEPS European Policy Analysis, no 6, pp. 1-8. Available at: http://www.ose.be/files/midi_OSE/Dewitte_2011_6_sieps_paper.pdf; Kunstein T. and Wessels W. (2013) The New Governance of the Economic and Monetary Union: Adapted Institutions and Innovative Instruments // IAI Working Papers, no 1302. Available at: https:/www.files.ethz.ch/isn/157646/iaiwp1302.pdf; Wessels W. (2016) The European Council, Palgrave Macmillan, pp. 187-209.

98 Parliament slams Troika, calls for a 'European Monetary Fund' // Euractiv, March 14, 2014. Available at: https:/www.euractiv.com/section/euro-finance/news/parliament-slams-troika-calls-for-a-european-monetary-fund.

${ }^{99}$ Scharpf Fritz W. (2015) After the Crash: A Perspective on Multilevel European Democracy // European law Journal, Vol. 21, Issue 3, May, pp. 384-385.

${ }^{100}$ Moravcsik A. (2002) Reassessing legitimacy in the European Union // Journal of Common Market Studies, vol. 40 , no 4, pp. 603-624.
} 
Отметим, что, несмотря на бурную дискуссию в академических кругах, на практике вплоть до 2009-2010 гг. Экономический и валютный союз оставался вполне легитимным и острого дефицита демократии не испытывал. Жесточайший мировой финансовый кризис составил исключительный вызов для ЕС, побудив его руководство действовать максимально быстро, что, само по себе, не располагало к длительному демократической делиберации. При урегулировании кризиса и создании новой системы экономического управления в Евросоюзе в 2010-е годы, о чём мы ещё будем подробнее говорить в следующих главах, приоритет был отдан оперативному устранению накопившихся острых проблем и решениям ad hoc. Но вот тому, чтобы процесс стал более демократичным и полностью подотчётным, не уделялось достаточного внимания.

После получения ЕЦБ новых полномочий многие эксперты стали призывать к совершенствованию форм его отчётности. Они настаивали, что его нельзя более, как раньше, рассматривать в качестве независимого административного агентства (типичного немажоритарного института $)^{101}$.Теперь Европейский центральный банк превратился в орган с конституционными функциями, влияние которого систематически сказывается на стабильности Европейского союза. Соответственно, для его функционирования потребовались более жёсткие демократические рамки ${ }^{102}$.

В связи с опытом изучения европейского Экономического и валютного союза вопрос о том, как обеспечить легитимность экономического управления, преодолевающего национальные границы, обретает дополнительную остроту ${ }^{103}$. Решение же этой задачи, вопреки утверждениям таких авторов, как Хуг и Маркс или Эндрю Моравчик, многократно осложняется тем, что ЭВС асимметричен с точки его институционального дизайна. В отношении кредитно-денежной политики и исключительно для 19 стран ЕС, которые перешли на единую валюту евро ${ }^{104}$, действует жёсткий наднациональный метод, который отличается закрытостью и недемократичностью. Одновременно с этим та часть ЭВС, которая относится к экономическому союзу, формально является воплощением межправительственного начала. Она основана на принципе добровольной координации действий правительств государствчленов как условии для дальнейшего продвижения по интеграционному пути, но при этом на практике отношения между правительствами в рамках системы координации выстроены иерархически: государства-члены, выступающие кредиторами, доминируют в отношении государств-членов, являющихся должниками ${ }^{105}$.

Таким образом, с одной стороны, мы наблюдаем в Европейском союзе независимый, наднациональный центральный банк. С другой стороны, сложилась децентрализованная система управления в бюджетной и социально-экономической области, где действуют различные правила и договорённости, нацеленные на то, чтобы обеспечить гармонизацию и координацию государствами-членами курсов своей бюджетной политики. Речь идёт, в первую

\footnotetext{
${ }^{101}$ Scotto N. (2012) Chapter 11: How does the financial crisis affect the independence of the European Central Bank? The European Rescue of the European Union? The existential crisis of the European political project // Edoardo Chiti, Agustín José Menéndez and Pedro Gustavo Teixeira (eds.) ARENA Report No 3/12, RECON Report No 19. ARENA Centre for European Studies Oslo, pp. 347-390. Available http://www.reconproject.eu/main.php/RECONreport1912.pdf?fileitem=50487366.

${ }^{102}$ Högenauer A.-L. \& Howarth D. (2016) Unconventional Monetary Policies and the European Central Bank's problematic democratic legitimacy // Journal of Public Law, vol. 17, no 2, Vienna: Verlag, pp. 1-24. Available at: https://orbilu.uni.lu/bitstream/10993/28059/1/H\%C3\%B6genauer_Howarth\%20Unconventional\%20Monetary\%20Polic ies\%20and\%20the\%20ECBs\%20problematic\%20democratic\%20-egitimacy_authors\%27_pre-print.pdf.

${ }^{103}$ Chopin Th. (2016) Euro zone, legitimacy and democracy: how do we solve the European Democratic problem? // European issues, $\mathrm{n}^{\circ} 387$, 05th April. Available at: https:/www.robert-schuman.eu/en/doc/questions-d-europe/qe-387en.pdf.

104 Австрия, Бельгия, Голландия, Германия, Греция, Ирландия, Испания, Италия, Кипр, Латвия, Литва, Люксембург, Мальта, Португалия, Словакия, Словения, Финляндия, Франция, Эстония.

${ }^{105}$ Fabbrini S. (2016) From consensus to domination: the intergovernmental union in a crisis situation // Journal of
} European Integration, vol. 38, issue 5, pp. 587-599. 
очередь, о гармонизации налогообложения и координации стабилизационной фискальной (бюджетной) политики. В таких условиях легитимность институтов ЭВС фактически поставлена в зависимость от колебаний подразумеваемых преимуществ и недостатков единой валюты для государств еврозоны.

Ещё при создании Единого внутреннего рынка было понятно, что он может разрушающе действовать на национальные системы благосостояния, провоцируя политическую мобилизацию населения отдельных стран с требованиями к национальным правительствам прекратить эрозию мер по социальному обеспечению. Но многоуровневое управление помогает Европейскому союзу продолжать неолиберальный европейский курс, несмотря на подобное внутриполитическое давление.

При этом одни авторы настаивают, что проблема легитимности ЭВС связана, в первую очередь, с необходимостью укрепления его демократических основ, а конкретнее подотчётности ЕЦБ и других европейских институтов народу и его избранным представителям ${ }^{106}$. Но для других она провоцируется озабоченностью проблемами суверенитета, то есть зависит от (не)готовности отдельных государств-членов отказаться от национальных валют в пользу евро, передать контроль над кредитно-денежной политикой наднациональным институтам и плотнее координировать национальные курсы экономической политики. В конечном счёте, проблема легитимности имеет прямое отношение к внутриполитической поддержке евро в отдельных европейских странах.

Несмотря на продолжающиеся институциональные подвижки, с политической точки зрения, ощутимого прогресса в еврозоне пока не наблюдается, и фактическая способность к принятию результативных решений, вопреки намерениям авторов институциональных реформ последнего времени, даже снизилась. Зачастую безрезультатные, конфликтные, затяжные переговоры между странами ЕС демонстрируют пределы межправительственного метода управления, в котором приёмы дипломатии держат верх над соблюдением демократических требований.

Мы можем согласиться с тем, что Европейский союз имеет полноценную политическую систему и некоторые работоспособные механизмы демократического контроля. Но если европейские элиты активно участвуют в его политике и полностью включены в неё, то массовый интерес к европейской политике и тем более контроль над нею со стороны европейского общества остаются недостаточными.

Наднациональная централизация и национальный суверенитет в системе ЕС находятся в обратной зависимости друг от друга. При этом дальнейшая централизация, вероятно, помогла бы повысить эффективность действий институтов Союза в экономической области, а сохранение национального суверенитета в принципе помогает укреплять демократические качества интегрированной системы в целом.

Вопросы суверенитета оказались, по сути, решающими в сложившейся на данный момент ситуации в Европе. Требование восстановить национальный суверенитет относительно политики ЕС исходит от популистских движений во многих странах и даже доминирует в риторике некоторых правительств государств-членов. Но волнениями по поводу суверенитета во многом объясняются и требования, выдвигаемые в адрес центральной национальной власти в Шотландии, Каталонии и Ломбардии.

Разгоревшаяся борьба вокруг восстановления прежних форм суверенитета опровергла представления о том, что с развитием процесса европейской интеграции понятие суверенитета уйдёт в прошлое. Поэтому в условиях глобализации, цифровой революции и повышенной

\footnotetext{
${ }^{106}$ Amtenbrink F. (1999) The Democratic Accountability of Central Banks: A Comparative Study of the European Central Bank, Oxford: Hart; Buiter W. H. (1999) Alice in Euroland//Journal of Common Market Studies, vol. 37, no 2, pp.181-209.
} 
глобальной мобильности сейчас необходимы новые подходы для осмысления современных мотивов и политики продвижения суверенитета в условиях региональной интеграции.

По крайней мере, ясно, что тот компромиссный вариант между наднациональной централизацией и сохранением национального суверенитета, которого удалось достичь правящим кругами ЕС на практике, не пользуется убедительной поддержкой европейских граждан, из-за чего объединению продолжают грозить опасные негативные политические последствия. Передача наверх всё новых долей национального суверенитета в особенности может обернуться потерей гражданами отождествления себя с европейским проектом и, как мы наблюдаем, отсутствие чувства принадлежности к нему способно порождать нарастание дефицита демократии в Европейском союзе и сопутствующую тягу к восстановлению независимости национального государства в ущерб ЕС.

Для европейских граждан понятнее было бы восстановление более чёткого деления на правые и левые силы в общем политическом спектре, привычного для них на национальном уровне, но на европейском уровне политики оно, по большому счёту, не воспроизводится. В то же время у ЕС по-прежнему нет широких наднациональных полномочий в некоторых из областей, которые для граждан составляют предмет их ежедневного интереса (налоги, внутренняя и международная безопасность).

Помимо прочего, значительную часть проводимой ЕC политики можно охарактеризовать как не имеющую ярко-выраженного политического значения (она остаётся технократической). Хотя роль ЕП значительно выросла в ходе внесения всё новых поправок в договорную основу интеграции, в области ЭВС, как можно дополнительно убедиться по ходу дальнейшего чтения настоящей публикации, она остаётся значительно менее существенной. На этом противоречивом фоне Брюсселю требуется продолжить поиски более адекватных способов вовлечения национальных парламентов в процесс принятия решений на уровне ЕС, как и укрепления их полномочий на национальном уровне, пострадавших в ходе интенсивной европеизации. Для благополучия Европейского союза у национальных парламентов должны сложиться более надёжные инструменты по формированию политики отдельных государствчленов в отношении ЕС, как и по надзору за действиями в этой сфере национальных министров и чиновников. 


\section{Глава 2}

\section{ВАЛЮТНЫЙ СОЮЗ}

Строительство Европейского союза - это уникальный долговременный политический эксперимент, у которого отсутствуют прямые прецеденты в истории. При этом до перехода к стадии Экономического и валютного союза компетенция ЕС затрагивала в основном вопросы, не обретавшие острой политической значимости, что могло бы сделать их предметом систематической борьбы в демократических рамках. Однако логика наднационального валютного союза, который материализовался в конце 1990-х годов, уже решительно не укладывалась в ту же категорию. Даже если признавать денежно-кредитную политику узкоспециальной отраслью, требующей от тех, кто ею занимается, исключительных экспертных знаний, то и в этом случае у соответствующих решений могут быть самые широкие общественные (для кого-то весьма болезненные) последствия. На самом деле немного найдётся вопросов, потенциально столь же чувствительных в политическом смысле, как устойчивость (над)национальной валюты.

Эффективность денежно-кредитной политики в еврозоне в объективном смысле определяется способностью Европейского центрального банка обеспечивать ликвидностью финансовые рынки таким образом, чтобы гарантировать полноценное и надёжное функционирование макроэкономики. Но с точки зрения оценки её легитимности денежнокредитная политика ЕЦБ была изначально заточена на достижение определённых, заранее установленных целей - главным образом, если не исключительно, цели поддержания ценовой стабильности, которая рассматривалась как техническая, а не политическая. О действиях ЕЦБ принято стало судить на основании того, насколько хорошо он выполняет свой (якобы сугубо технический) мандат ${ }^{107}$.

Если руководствоваться представлениями, на основании которых денежно-кредитная политика в принципе нуждается в изоляции от возможности прямого политического оспаривания принимаемых в её рамках решений, то передача соответствующих (оцениваемых как технические) задач на наднациональный уровень не должна вызывать особых вопросов с точки зрения её правомерности. Но проблемы с легитимностью неизбежно возникают (или обостряются) тогда, когда ЕЦБ (что происходит на практике в 2010 годы) накапливает всё новые функции, а его деятельность резко и самым наглядным образом политизируется.

Если в валютном союзе участвуют суверенные государства, в каждом из которых заранее сложились собственные теоретические и идеологические позиции касательно предпочтительных правил экономической и денежно-кредитной политики, то легитимность «на входе» на национальном уровне непросто с лёгкостью заместить легитимностью «на выходе» на европейском уровне - в особенности если выгоды от интеграции меняются со временем и неравномерно поделены между участниками объединения таким образом, который может быть кем-то расценен как несправедливый ${ }^{108}$.

В приложении к ЭВС такой манёвр с переносом легитимности, в конце концов, оказался ущербным, так как в ходе него были проигнорированы особенности политической

\footnotetext{
${ }^{107}$ Zilioli Ch. (2016) The Independence of the European Central Bank and Its New Banking Supervisory Competences //The Independence and Legitimacy in the Institutional System of the European Union / Ed. by D. Ritleng - Oxford: Oxford University Press, p. 131.

${ }^{108}$ Bellamy R. and Weale A. (2015) Political legitimacy and European monetary union: contracts, constitutionalism and the normative logic of two-level games // Journal of European Public Policy, vol. 22, issue 2, pp. $257-274$.
} 
игры на двух уровнях (национальном и наднациональном). В либеральной логике подобной игры, которую в самом общем виде первым описал Роберт Патнэм ${ }^{109}$ и отразил затем в межправительственном теоретическом подходе к европейской интеграции Эндрю Моравчик $^{110}$, правительства не только несут обязательства друг перед другом, но и продолжают быть подотчётными своим собственным гражданам, от которых и зависит их политическая легитимность.

С абстрактной точки зрения устойчивого баланса между эффективностью и легитимностью институтов валютного союза легче всего было бы добиться для оптимальной валютной зоны - OB3 (optimum currency area). Данное понятие было введено в научный оборот канадцем по происхождению, лауреатом Нобелевской премии 1999 года по экономике Робертом Манделлом (Robert Mundell) в довольно далёком от сегодняшнего дня 1961 г. ${ }^{111}$. Оптимальную валютную зону в его тогдашней трактовке можно описать как предпочтительное (особо благоприятное) (транс)национальное или (транс)региональное политическое пространство для единой валюты или для нескольких валют, обменные курсы которых необратимым образом закреплены относительно друг друга. Такие валюты совместно колеблются по отношению к валютам третьих стран.

Оптимальная валютная зона - это пространство, для которого преимущества от создания валютного союза (взаимной фиксации курсов национальных валют) для всех его участников должны превышать возможные издержки (её организация в идеале должна соответствовать требованиям обеспечения Парето-эффективности). Оформление ОВ3, где налицо высокая мобильность рабочей силы, высокая эластичность цен и низкие государственные долги, по крайней мере в теории, позволяет предотвращать кризисы или относительно легко выходить из возникающих экономических кризисов с помощью обычных инструментов регулирования рынка ${ }^{112}$. Теория оптимальной валютной зоны предсказывает, таким образом, что странам есть резон объединяться в валютный союз, если наблюдается высокая мобильность трудовых ресурсов и капиталов между ними, если в пределах зоны осуществляются бюджетные (фискальные) трансферты, а их экономики отличает высокая степень открытости ${ }^{113}$.

Но на деле внешние границы валютной зоны (зоны валютной интеграции) определяются не экономистами-теоретиками, а руководителями суверенных государств, которые принимают решение в ней участвовать (или отказываются от этого) по самым разным, преимущественно политическим, причинам. Впрочем, оптимальность реальной валютной зоны вполне допустимо оценивать с точки зрения различных экономических параметров:

\footnotetext{
${ }^{109}$ Putnam R. (1988) Diplomacy and domestic politics: the logic of two-level games // International Organization, vol. 42, issue, 3 , pp. 427-460.

${ }^{110}$ Moravcsik A. (1993) Preferences and power in the European Community: a liberal intergovernmentalist approach // Journal of Common Market Studies, vol.31, issue 4, pp. 473-524.

${ }^{111}$ Mundell, R.A. (1961) A Theory of Optimum Currency Areas // American Economic Review, vol. 51, no 4, pp. 657665; Mundell, R. A. (1973) A Plan for a European currency // The Economics of Common Currencies / Ed. by H.G. Johnson and A.K. Swoboda - London: Allen and Unwin, p. 143-172; Mundell, R. A. (1997) "Optimum Currency Areas", extended version of a luncheon speech at Tel-Aviv University, available at: http://www.columbia.edu/ ram15/eOCATAviv4.html;Kenen, P. (1969) The theory of optimum currency areas: An Eclectic View // Monetary Problems of the International Economy / Ed. by R.A. Mundell and A.K. Swoboda -Chicago and London: The University of Chicago Press, pp. 41-60; Kunroo M.H. (2015) Theory of Optimum Currency Areas: A Literature Survey // Review of Market Integration, vol. 7, issue 2, pp. 87-116.

${ }^{112}$ Kenen P. (1969) Op. cit.

113 Цибулина А.Н. (2013) Экономический и валютный союз ЕС: работа над ошибками // Вестник МГИМО$\begin{array}{llllll}\text { Университета, № } & \text { 4(31), } & \text { c. } & 114 & \text { Available }\end{array}$ http://www.vestnik.mgimo.ru/sites/all/themes/adaptivetheme/professional_theme/vestnik(4-31-2013).pdf.
} 
таких как эластичность цен, изменяемость ставки заработной платы или достигнутая участниками степень финансовой интеграции ${ }^{114}$.

Как многократно было отмечено разными авторами, еврозона не всем упомянутым критериям OB3 соответствует в удовлетворительной мере ${ }^{115}$. В частности, в Европейском союзе по сию пору трудовая мобильность остаётся на низком уровне ${ }^{116}$. Она многократно более низкая, чем, скажем, в Соединённых Штатах Америки, и потому не годится в качестве надёжного механизма рыночной стабилизации ${ }^{117}$.

В Европе повышению мобильности рабочей силы (порой даже внутри отдельных стран), среди прочего, мешают глубоко укоренённые культурные, языковые и институциональные барьеры, а также щедрые пособия по безработице и высокие ставки минимальной заработной платы, угнетающие охоту работников к «перемене мест». Если в США региональный шок относительно быстро преодолевается оттоком работников в другой штат (регион), то в Европе результатом странового шока сплошь и рядом становится более высокая безработица в этой стране.

В то же время оговоримся, что самим Соединённым Штатам Америки, чтобы достичь удовлетворительного состояния полнофункционального валютного союза, потребовались полторы сотни лет ${ }^{118}$. Поэтому сравнение уже реализованного валютного союза (США) с тем, который ещё продолжает строиться (ЕС), вероятно, в принципе не слишком корректно. Кстати говоря, Манделл, парадоксальным образом (т.е. вопреки сомнениям, вытекавшим из предложенной им же в 1960-е годы теории, остававшейся в русле кейнсианского мейнстрима того времени), ещё в 1960-х годах превратился в одного из самых активных приверженцев идеи европейской валютной унификации. В декабре 1969 г. он представил доклад, изложив в нём свои аргументы в пользу будущей европейской валюты, на этот раз в большей мере отталкиваясь от монетаристских постулатов ${ }^{119}$. В переработанном виде этот доклад Манделла, в качестве плана по введению европейской валюты, был обнародован в марте 1970-го года. Это произошло на конференции в Мадриде, посвящённой оптимальным валютным зонам ${ }^{120}$.

План «по отучению Европы от долларовой зависимости», предложенный Манделлом, состоял в первоначальном выборе валюты одной из европейских стран (сам он в этом смысле отдавал предпочтение британскому фунту стерлингов) в качестве «новой» расчётной

\footnotetext{
${ }^{114}$ Tichy G. (1992) Theoretical and Empirical Considerations on the Dimension of an Optimum Integration Area in Europe // Aussenwirtschaft, vol.47, issue 1, pp. 107-37.

115 Ester Peter and Hubert Krieger (2008) Comparing labour mobility in Europe and the US: facts and pitfalls // Over.Werk. Tijdschrift van het Steunpunt WSE, 18(3-4): 94-98. URL: https://www.steunpuntwerk.be/system/files/overwerk_2008_3-4_12.pdf; Gesa P. and Vasilescu L.G. (2011) The Optimum Currency Area. Is the Euro an Optimum Currency Area? // MPRA Paper, no. 29656. Available at: https://mpra.ub.uni-muenchen.de/29656/1/MPRA_paper_29656.pdf; Mongelli F.P. (2008) European Economic and Monetary Integration, and the Optimum Currency Area Theory // European Economy - Economic papers, No 302 , February. Available at: http://ec.europa.eu/economy_finance/publications/pages/publication12081_en.pdf.

${ }^{116}$ В кризисные годы несколько возросла эмиграция из стран Южной Европы в другие страны ЕС, относительно высокой является стабильная эмиграция из Латвии и Литвы, но в целом по-прежнему нет основании для переоценки сложившейся ситуации.

${ }^{117}$ European Commission (2017) Additional effects of a European Unemployment Benefit Scheme, Luxembourg: Publications Office of the European Union, p. 7-8.

${ }^{118}$ Rockoff H. (2003) How Long Did It Take the United States to Become an Optimal Currency Area? // Monetary Unions: Theory, History, Public Choice / Ed. by F. H. Capie and G. E. Wood - London: Routledge, pp. 70-103.

119 Сам Манделл легко признавался в собственной теоретической «всеядности»: «В самой краткосрочной перспективе я кейнсианец. В среднесрочной перспективе я сторонник экономики предложения, но в долгосрочной перспективе я монетарист». Цит. по: Bennet R.A. Eccentric Economist: Robert A. Mundell; SupplySide's Intellectual Guru. 1986. URL: https://www.nytimes.com/1986/01/12/business/eccentric-economist-robert-amundell-supply-side-s-intellectual-guru.html.
}

${ }^{120}$ Mundell R.A. (1973) Op. cit. 
единицы, относительно которой прочие западноевропейские страны смогут зафиксировать свои обменные курсы ${ }^{121}$.

Напомним ещё раз, что литература по теории ОВ3 впервые привлекла к себе внимание в Европе в начале 1960-х годов ${ }^{122}$, когда в экономической науке ещё преобладали кейнсианские установки, в период, основные отличительные черты которого включали режим фиксированных (но подлежавших корректировке) обменных курсов, наличие во многих странах ограничений на движение капитала и только ещё зарождающийся процесс (западно)европейской интеграции.

Различные критерии, или характеристики, ОВ3 были сформулированы в ходе споров по поводу сравнительных преимуществ фиксированных и гибких курсов обмена валют и сравнения экономики США (и Канады) с Западной Европой. Для более детальных суждений о том, что же побудило западноевропейские правящие круги пуститься в такое, довольно рискованное, предприятие, как строительство Экономического и валютного союза, следует обратиться к истории валютного сотрудничества в Европейском (экономическом) сообществе, которое и вылилось впоследствии в валютную интеграцию.

«Отцы-основатели» интегрированной Европы в 1950-е годы не помышляли о единой валюте. Первоначальные цели ЕЭС ограничивались созданием таможенного союза и общего сельскохозяйственного рынка, которые, как они полагали, не требовали серьёзной интеграции в валютной области. Первые робкие шаги в направлении будущей европейской валютной интеграции, тем не менее, практически совпали по времени с появлением теории ОВ3. В октябре 1962 г. Европейская комиссия выпустила так называемый меморандум Маржолена ${ }^{123}$. В нём впервые было предложено создание экономического и валютного союза, как более продвинутой формы интеграции, между государствами-членами западноевропейской «шестёрки». В его тексте отмечалась непрочность Бреттон-Вудской системы золотодевизного стандарта $^{124}$ (первый связанный с нею кризис разразился в октябре 1960 г.), куда входили все страны ЕЭС, и в связи с этим необходимость для стран Сообщества нарастить собственные, независимые от США, возможности для отстаивания своих позиций в международных валютно-финансовых отношениях.

В Меморандуме Маржолена Комиссия призывала правительства добиваться фиксации обменных курсов валют государств-членов относительно друг друга к концу 1960-х годов. Однако на тот момент Бреттон-Вудская система продолжала функционировать, и правительства стран шестёрки рассудили, что для поддержания стабильности обменных курсов внутри ЕЭС пока можно обойтись без новых институциональных договорённостей на уровне Сообщества. Бреттон-Вудская система была дополнительно «удобна» тем, что помогала тогдашним правительствам участвующих в ЕЭС стран поддерживать свою

\footnotetext{
121 McKinnon R. Mundell, the Euro, and Optimum Currency Areas. May 22, 2000. URL: https://notendur.hi.is/ajonsson/kennsla_2012/updating_mundell.pdf.

${ }^{122}$ Mundell R.A. (1961) Op. cit.

${ }^{123}$ Робер Маржолен (Robert Marjolin) - член Комиссии ЕЭС по экономическим и финансовым вопросам в $1958-$ 1967 гг. Подробнее см.: Paun Ch. (2018) The euro and European monetary policy: a critical view // Doing Business in Europe. Economic Integration Processes, Policies and the Business Environment / Ed. by A.N. Dima - Cham, Switzerland: Springer, pp. 127-128.

${ }^{124}$ Бреттон-Вудская система - международная валютная система, сформировавшаяся после Второй мировой войны и базировавшаяся на приспособлении национальных валютных систем к валютным системам ведущих в то время государств, прежде всего к национальной системе США. Система организации денежных отношений и торговых расчётов была установлена в результате Бреттон-Вудской конференции (июль 1944 г.) Система положила начало таким организациям, как Международный банк реконструкции и развития (МБРР) и Международный валютный фонд (МВФ). Новая валютная система предполагала тогда золотодевизный стандарт на основе доллара США и английского фунта стерлингов. Возможность обмена национальных валют на доллары с последующим обменом долларов на золото вылилась в перераспределение золота в пользу Западной Европы. В начале 1970-х годов США вынужденно отказались от Бреттон-Вудской валютной системы.
} 
экономику, наращивая финансирование для строительства государства с развитой социальной системой $^{125}$.

Впрочем, Меморандум не только подтолкнул к началу обсуждения будущей общей валюты, но и повлёк за собой некоторые практические меры в институциональной области. В 1964 г. в дополнение к Валютному комитету, учреждение которого предусматривалось статьёй 105(2) Римского договора 1957 г. о создании ЕЭС, был также создан комитет глав центральных банков государств-членов ЕЭС - Комитет управляющих. Мандат у Комитета управляющих был сначала весьма ограниченный, но с течением времени он набрал более солидный вес ${ }^{126}$. В 1990 г. им был подготовлен первый проект статута ЕЦБ.

Между тем к началу 1970-х годов международные условия изменились. США постепенно утратили способность сохранять обратимость доллара в золото в рамках БреттонВудской системы (сумма краткосрочных обязательств США превысила сумму имевшихся в стране запасов золота), но и внутри западноевропейской шестёрки приоритеты в национальной экономической политике существенно разошлись, что приводило к резким колебаниям валютных курсов и к нарушению платёжных балансов. В 1968-1969 гг. была ревальвирована западногерманская марка, претерпел девальвацию французский франк, что поставило под угрозу систему цен в рамках общей сельскохозяйственной политики и имело негативные последствия для внутриевропейской и международной торговли государствчленов. Чтобы со всем этим справиться, Комиссия представила план Барра ${ }^{127}$ по наделению ЕЭС собственной валютной идентичностью. 17 июля 1969 г. это план был одобрен Советом министров ЕЭС ${ }^{128}$

На основании плана Барра группа экспертов под руководством премьер-министра Люксембурга Пьера Вернера, действуя по поручению Совета министров ЕЭС, разработала постадиальный план построения к 1980 г. экономического и валютного союза ${ }^{129}$. В рамках его реализации в апреле 1972 г. на свет появилась система, нацеленная на последовательное сокращение пределов колебаний курсов валют стран-участниц. Она получила неофициальное наименование «змеи в тоннеле». На участие в «змее» пошли шесть стран ЕЭС (ФРГ, Франция, Италия, Нидерланды, Бельгия, Люксембург) из тогдашних девяти. Но под давлением нефтяного кризиса 1973 г. процесс (западно)европейской интеграции вскоре утратил темп поступательного развития. «Змея в тоннеле» быстро сократилась до механизма регулирования валютных курсов западногерманской марки, валют стран Бенилюкса и датской кроны (в течение некоторого времени в системе участвовали также шведская и норвежская крона, т.е. валюты стран, не принадлежавших к Сообществу). Валюты прочих стран Сообщества не входили в этот механизм в течение большего времени его существования.

Интеграционная стратегия, на которую ориентировался план Вернера, исходила из не оправдавшего себя ожидания, что обменные курсы европейских валют по отношению к доллару США всё же будут оставаться стабильными. Страны ЕЭС решились теперь действительно ослабить свою валютную привязку к доллару (в 1973 г. пределы колебаний курсов валют западноевропейских стран по отношению к доллару были отменены).

125 Bolton S. A History of Currency Unions. December 10,2001 URL: https://www.theguardian.com/world/2001/dec/10/euro.eu.

126 Andrews D. (2003) The Committee of Central Bank Governors as a source of rules //Journal of European Public Policy, vol.10, issue 6, December, pp. 956-973.

${ }^{127}$ Раймон Барр - член Комиссии ЕЭС по экономическим и финансовым вопросам в 1967-1973 гг.

${ }^{128}$ Rodica E. (2012) The first and second Barre Plans // A Rereading of the Werner Report of 8 October 1970 in the light of the Pierre Werner family archives. Sanem: CVCE, 2012. Available at: https:/www.cvce.eu/content/publication/2011/12/1/a27c0587-77ad-479e-a644-cb56dbaf9c90/publishable_en.pdf.

${ }^{129}$ Szász A. (1999) The Werner Report. 1970 //The Road to European Monetary Union. London: Palgrave Macmillan, pp. 30-35. 
Новое предложение о валютном союзе в Западной Европе было выдвинуто в 1977 г. главой Европейской комиссии Роем Дженкинсом ${ }^{130}$, но оно не встретило достаточной поддержки. Однако менее амбициозную инициативу президента Франции Валери Жискар Д’Эстена и канцлера ФРГ Гельмута Шмидта по созданию Европейской валютной системы (EBC) удалось запустить в марте 1979 г. при участии восьми государств-членов ЕЭС: Германии, Франции, Нидерландов, Бельгии, Дании, Ирландии, Люксембурга и Италии (последняя в 1992 г. вышла из системы и вернулась в неё обратно в 1996 г.). Позднее к ЕВС, по мере его расширения, присоединились: Испания (в 1989 году), Великобритания (в 1990 году), Португалия (в 1992 году), Австрия (в 1995 году), Финляндия (в 1996 году), Греция (в 1998 году). На этот раз удалось удерживать большую часть валют стран Сообщества в рамках единой системы.

Некоторыми своими чертами ЕВС напоминала прежнюю «змею». Она тоже строилась вокруг сетки фиксированных, но регулируемых курсов национальной валюты. С целью сокращения курсовых колебаний был создан механизм регулирования валютных курсов (Exchange Rate Mechanism - ERM). Принципиально новым элементом стало введение условной валютной единицы ЭКЮ (European Currency Unit-ECU), представлявшей собой обобщённую корзину всех входивших в ЕВС валют. Был образован (за счёт взносов стран-участниц) Европейский фонд валютного сотрудничества (European Monetary Cooperation Fund - EMCF), предназначенный для временной поддержки участников в форме кредитов на покрытие дефицитов платёжного баланса и для осуществления расчётов по валютным интервенциям, которые проводили центральные банки для удержания валютных курсов в установленных пределах.

В рамках ЕВС была создана зона, в которой действительно удалось повысить стабильность валютных курсов, а меры контроля над движением капитала были постепенно ослаблены. В то же время и в этом случае достигнутый успех следует признать неполным. ЭКЮ, которой в ЕВС разработчиками отводилось центральное место, на деле сыграла ограниченную роль в функционировании системы. После объединения Германии в ЕВС наблюдались заметные асимметричные шоки, а повышение мобильности капитала усугубило уязвимость отдельных участвовавших в ней стран. В 1992-1993 гг. спекулятивное давление вытолкнуло из ЕВС Италию и Великобританию. Отправной точкой тяжёлого кризиса ЕВС послужил референдум по Маастрихтскому договору в Дании 2 июня 1992 г., принесший отрицательный результат. В августе 1993 г., чтобы реанимировать ЕВС, допустимый предел взаимных колебаний валют в рамках системы был расширен до $\pm 15 \%$.

Важный толчок к развитию валютной интеграции был дан в 1986 г. с принятием Единого европейского акта (он вступил в силу в 1987 г.). Главной целью ЕЕА было создание Единого внутреннего рынка. В правящих кругах Сообщества сложилось к тому моменту общее понимание, что единый рынок без внутренних границ свяжет западноевропейские национальные экономики гораздо теснее, чем действовавший раньше Общий рынок, повысив достигнутый уровень экономической интеграции. Это, в свою очередь, должно было снизить пространство манёвра для национальных правительств и обязать государства-члены повысить меру сближения курсов национальной экономической политики. Если бы такого сближения не произошло, полная свобода движения капитала и интегрированные финансовые рынки, как ожидалось, стали бы оказывать чрезмерное давление на национальную монетарную политику. Кроме того, ЕВР не мог бы развернуться в полную меру без единой валюты, которая должна была обеспечить транспарентность цен для потребителей и инвесторов, устранить риски, связанные со скачками обменных курсов, и снизить транзакционные издержки.

\footnotetext{
${ }^{130}$ Рой Дженкинс - британский и европейский государственный деятель, глава Комиссии ЕЭС в 1977-1981 гг. Jenkins Roy. Europe's present challenges and future opportunity. Florence: 27.10.1977. Archives familiales Pierre Werner, Luxembourg. URL: https://www.cvce.eu/content/publication/2010/11/15/98bef841-9d8a-4f84-b3a8719abb63fd62/publishable_en.pdf.
} 
С учётом всего этого 12 государств-членов, которые в то время входили в Европейское сообщество, в 1988 г. решились на перезапуск проекта ЭВС, который не удалось реализовать ранее. Подписанный в феврале 1992 г. Маастрихтский договор учредил Европейский союз и, в числе других изменений, добавил к договорной основе интеграции новую главу по Экономическому и валютному союзу, определившую метод и сроки его строительства. Курсы валют 11 государств-членов, вступивших первыми в Валютный союз в 1999 г. (Австрии, Бельгии, Германии, Ирландии, Испании, Италии, Люксембурга, Нидерландов, Португалии, Финляндии и Франции, к которым вскоре присоединилась Греция), были зафиксированы необратимо, а ЕЦБ взял на себя ответственность за проведение единой денежно-кредитной политики в еврозоне.

Дания и Великобритания получили по Маастрихтскому договору особый статус, который вывел их из-под обязательства участвовать в переходе на единую валюту (в третьей и завершающей стадии строительства ЭВС). При этом если Великобритания собирается выйти из ЕС в 2019 г., то Дания вправе в любое время изменить своё решение по поводу перехода на евро и присоединиться к еврозоне в будущем.

Ни ЭВС, ни создание ЕВР не были для европейских правящих кругов того времени самоцелью. По их представлениям, ЭВС и ЕВР должны были способствовать достижению основополагающих целей Союза, включая устойчивое развитие европейской экономики, высокий уровень занятости, экономический рост, не подверженный инфляции, высокую конкурентоспособность и сближение экономических показателей стран-участниц.

Членство в Европейском союзе не подразумевает автоматически участия в еврозоне. Помимо Дании и Великобритании, уже упомянутых, которые каждая имеют в данном отношении свой постоянный особый статус, остальным государствам-членам нужно предварительно выполнить определённые условия экономической конвергенции и обеспечить совместимость национального законодательства с договорными положениями по ЭВС. Не выполнившее этих условий государство-член в единой валютной зоне не участвует. Оно (временно) сохраняет валютный суверенитет и собственную валюту, а также национальные полномочия в денежно-кредитной области. В настоящее время это касается Швеции и шести стран, присоединившихся к ЕС, начиная с 1 мая 2004 г. (Болгарии, Венгрии, Польши, Румынии, Словакии, Чехии).

Решение о создании ЭВС послужило ответом на следующие внутренние для Европейского союза вызовы.

Во-первых, либерализация движения капиталов, необходимая для завершения строительства Единого внутреннего рынка, затруднила задачу стабилизации колебаний обменных курсов в рамках ЕВС.

Во-вторых, ввиду мощи немецкой экономики и последовательного курса Центрального банка ФРГ, в функционировании ЕВС всё больше доминировала денежно-кредитная политика Германии, а потому создание ЕЦБ могло расцениваться другими странами как способ уйти от нежелательного одностороннего германского доминирования в монетарной сфере.

В-третьих, объединение Германии в принципе актуализировало задачу развития экономической и политической интеграции в Европе.

Таким образом, будущая единая валюта обещала устранить неразбериху с обменными курсами государств-членов Европейского сообщества и давала шанс несколько снизить германское преобладание в кредитно-денежных делах, при этом закрепив объединённую Германию в европейском интеграционном объединении. Одновременно с тем конкретный замысел ЭВС в существенной мере учитывал традиционную озабоченность Германии в отношении опасностей инфляционного давления на экономику. 
На реализации идеи валютного союза во второй половине 1980-х годов настаивали, прежде всего, Франция, а также Италия ${ }^{131}$. Их активно поддерживала в этом Европейская комиссия. Доклад Делора ${ }^{132} 1989$ г., принятый в качестве основы для строительства ЭВС на сессии Европейского совета в Мадриде в июне 1989 г., предусмотрел три этапа, из которых решающий, третий этап должен был проходить в 1997-1999 гг. (евро стал реальной валютой, начиная с 1 января 1999 г.). Но с момента оформления ЭВС в академических кругах не утихают споры о преимуществах и издержках единой наднациональной валюты.

Особый предмет беспокойства для архитекторов ЭВС составляло то, что после перехода на единую валюту страна, испытывая асимметричный шок (резкое экзогенное изменение в собственной экономической системе), чтобы выправить ситуацию, не сможет более полагаться на самостоятельную денежно-кредитную политику, - за отсутствием таковой. Асимметричные шоки, по определению, поражают отдельные страны, регионы или отрасли сильнее, нежели другие. Но, присоединившись к валютному союзу, страна лишается важных инструментов по предотвращению экономических потрясений или минимизации их воздействия на сферу занятости и доходы населения, которыми она могла бы воспользоваться, если бы сохранила полную способность действовать самостоятельно.

В рамках ЭВС на смену национальной денежно-кредитной политике приходит политика общая. Её совместно ведут ЕЦБ и центральные банки вошедших в валютный союз стран, руководствуясь при этом уже коллективными, а не национальными, интересами. Страны еврозоны по отдельности не могут изменить обменный курс национальной валюты или прибегнуть к регулированию нормы процента, чтобы попытаться справиться со специфичными вызовами, хотя для этого у них ещё остаются в руках инструменты национальной фискальной политики.

Оптимистичные ожидания, что введение евро, несмотря на возможные риски, с ним связанные, поспособствует быстрому экономическому росту в ЕС, поможет решить проблему безработицы и позволит повысить общее благосостояние, по большому счёту, не оправдались. Единая валюта в долговременном плане не принесла в Европу макроэкономическую стабильность и, напротив, сама послужила провоцированию дестабилизирующих макроэкономических дисбалансов. Однако, признавая это, необходимо учитывать, что строительство валютного союза в Европе было движимо не только (или даже не столько) экономическими соображениями, но и сопутствующими политическими обстоятельствами.

Среди экономических соображений важнейшими представляются следующие:

1. Осознание, особенно европейскими деловыми кругами, комплементарности валютного союза относительного Единого внутреннего рынка, который начал функционировать чуть ранее (в 1993 г.);

2. Стремление снизить уязвимость европейских валют относительно внешних потрясений, подобных тем, что они испытывали в предшествующие пятнадцать лет;

3. Общее понимание, что свободному движению капитала лучше соответствовала бы объединённая валютная зона.

Таким образом, в 1970-е и 1980-е годы на смену расплывчатым начальным идеям касательно будущего Экономического и валютного союза пришли более сконцентрированные и конкретизированные программы, нацеленные на сокращение волатильности валютных курсов в Западной Европе после перехода от золотодевизного стандарта к плаванию валют. Но время показало, что в длительной перспективе они неработоспособны. Так называемая

\footnotetext{
${ }^{131}$ Quaglia L. and Maes I. (2004) France and Italy's Policies on European Monetary Integration: A Comparison of 'Strong' and 'Weak' States // Comparative European Politics, vol. 2, issue 1, pp. 51-72.

132 Жак Делор - глава Европейской комиссии в 1985-1995 гг. Он возглавил комитет, готовивший данный доклад в 1988-1989 гг. Delors J. (1989) Report on economic and monetary union in the European Community. Presented April 17, 1989 (commonly called the Delors Plan or Report) by Committee for the Study of Economic and Monetary Union. [EU Commission - Working Document]. Available at: httphabermas://aei.pitt.edu/1007/.
} 
змея в тоннеле, т.е. валютный коридор с узкими рамками (+/-1,125\%), введённый в 1972 г., работал со сбоями, а пришедшая ему на смену Европейская валютная система со временем оказалась размыта до такой степени, что позволительно стало говорить об утрате ею практического смысла ${ }^{133}$.

Между европейскими государствами в послевоенный период постоянно возникали экономические дисбалансы, потому что экономика Западной Германии была гораздо сильнее остальных и к тому же ориентирована на экспорт. Кроме того, Европа не могла оградить себя от политических прихотей Соединённых Штатов, которые неоднократно приспосабливали мировую финансовую систему, перекраивая её по собственному разумению и добиваясь, чтобы бремя такого приспособлению всякий раз несли не американские налогоплательщики и потребители, а торговые партнёры Америки. История строительства экономического и валютного союза в Европе стала историей попыток справиться с этими двумя взаимосвязанными проблемами (германской и американской).

По мнению российского экономиста Ольги Буториной, введение евро преимущественно диктовалось задачами, характеризуемые ею как негативные, которые были призваны защитить экономическое пространство ЕС от давления внешних факторов (предотвратить нежелательное развитие событий или избавить от дополнительных расходов). Под такими задачами этот автор понимает конкретные результаты, которые планировалось достичь, отказавшись от национальных денежных единиц - в том числе снизить зависимость ЕС от динамики доллара и экономической политики США ${ }^{134}$. Такая точка зрения в чём-то справедлива, но не отражает картины происходившего во всей полноте.

С политической точки зрения ускорению создания валютного союза, бесспорно, сильно поспособствовали также обстоятельства объединения Германии (оно произошло в 1990 г.). В частности, официальный Париж не торопился поддержать германское объединение, не получив заранее подтверждения готовности Бонна к дальнейшему прогрессу европейской интеграции. Важнейшим свидетельством такой готовности и должен был стать отказ Федеративной Республики Германия от немецкой марки в пользу наднациональной валюты. К слову, ещё более серьёзные сомнения в отношении грядущего германского объединения тогда продемонстрировал британский правящий класс. Германия, не без колебаний ${ }^{135}$, в итоге дала своё согласие на строительство ЭВС в декабре 1989 г., продемонстрировав стойкую приверженность интегрированной Европе, что позволило открыть Межправительственную конференцию по данному вопросу.

Переговоры, предшествовавшие подписанию Маастрихтского договора, в целом убеждают, что для таких политических деятелей, как министр иностранных дел ФРГ ГансДитрих Геншер ${ }^{136}$, канцлер ФРГ Гельмут Коль и президент Франции Франсуа Миттеран, стоявших у истоков единой европейской валюты, она была скорее средством к достижению в интеграции стадии политического союза ${ }^{137}$. При этом важно, что сначала Бонн настаивал на федералистском видении будущего европейского политического союза. Но в ходе дальнейших

\footnotetext{
${ }^{133}$ См.: Европейская интеграция: Учебник для вузов / Под ред. О.В. Буториной (отв. ред.), Н.Ю. Кавешникова. 2-е изд., М.: Аспект Пресс, 2016, с. 200-203.

134 Буторина О.В. (2017) Негативные и позитивные задачи Европейского валютного союза // Современная Eвpona, № 2, c. 18-29.

135 Жёсткими оппонентами отказа от немецкой марки выступали руководители западногерманского Бундесбанка.

136 План Делора1989 г. был подготовлен на базе меморандума Геншера «О создании европейского валютного пространства и Европейского центрального банка», обнародованного в начале 1988 г. См., например, Фрумак И.В. (2013) Процесс формирования Еврозоны // Вестник Камчатского государственного технического университета, № 26, с. 80-92.

${ }^{137}$ Woolley J. (1994) Linking Political and Monetary Union: The Maastricht Agenda and German Domestic Politics // The Political Economy of EMU / Ed. by B. Eichengreen and J. Frieden - Boulder, Colorado: Westview Press, pp. 67-86.
} 
переговоров Франции удалось внушить немцам понимание преимуществ межправительственного подхода при строительстве европейских институтов ${ }^{138}$.

В результате разнонаправленного и хаотичного влияния его создателей ЭВС имеет «недоработки» в конструкции ${ }^{139}$, в том числе касающиеся взаимоотношений между ЕЦБ и национальными правительствами, многие из которых экспертам были видны изначально. Рамки макроэкономической политики, заданные конструкцией ЭВС, были по сути либеральными - в том смысле, что в основе их лежало предположение о высокой эффективности рынков и их высокой способности самостоятельно (без правительственного вмешательства) обеспечить макроэкономическую стабильность и высокий уровень занятости. В этой связи денежно-кредитной политике фактически было поручено таргетирование инфляции, а фискальной политике национального уровня отводилась роль автоматического стабилизатора экономики.

Как указывал в своё время Эндрю Моравчик, на неолиберальной цели создания Единого внутреннего рынка в определённый момент сошлись политические интересы ключевых стран ЕС (Западной Германии, Франции и Великобритании) ${ }^{140}$. Возобновление поступательного развития европейской интеграции во второй половине 1980-х годов совпало по времени с серьёзными изменениями в политической идеологии. Золотая эра государства благосостояния, которое строилось по кейнсианским рецептам, подошла к концу. Она окончательно уступила место новой влиятельной идеологии - неолиберализму, с его особой надеждой на механизмы свободного рынка. За набором правил, которые были выбраны для ЭВС, стояли, таким образом, более общие предпосылки, касающиеся оценки природы демократического политического порядка. Современное европейское экономическое управление погрузило национальные демократические системы большинства стран Европы в наднациональную структуру экономической свободы.

Исходя из трактовки конституционного либерализма (предложенной Фридрихом Хайеком), у демократических правительств есть «дурная привычка» проявлять бюджетную безответственность, поскольку политики заинтересованы в привлечении голосов избирателей на выборах, для чего они способны порой безоглядно пуститься в наращивание государственных расходов. Стремясь к тому, чтобы их переизбрали на новый срок, политические деятели якобы зачастую предпочитают в краткосрочной перспективе потакать пожеланиям особых групп интересов вместо того, чтобы принимать законы, больше соответствующие интересам общества в долговременном плане. Ф. Хайек полагал, что во избежание подобных опасных подводных камней конституционные правила и механизмы лучше выстроить таким образом, чтобы не давать правительствам лишней возможности осуществлять траты и без особой надобности произвольным образом вмешиваться в функционирование свободного рынка.

Но сам Хайек ${ }^{141}$, кстати, не поддерживал при этом идею экономического и валютного союза, выступая за более радикальную свободную конкуренцию валют на основании отмены правительственной монополии на эмиссию денег и замены её конкуренцией частных эмитентов. Он вообще не считал, что экономическую политику нужно фиксировать правовыми средствами, будь то на национальном или наднациональном уровне. По его мнению, экономические порядки должны складываться в результате человеческой деятельности эволюционно (спонтанно, естественно), а не на основании «тяжеловесного»

\footnotetext{
${ }^{138}$ Bozo F. (2009) Mitterrand, the End of the Cold War, and German Unification, New York, NY: Berghahn Books.

${ }^{139}$ Arestis P. and Sawyer M. (2013) Must we move to a United States of Europe //Challenge, vol. 56, no. 3, pp. $42-52$.

${ }_{140}$ Moravcsik A. (1998) The Choice for Europe: Social Purposed State Power from Messina to Maastricht. Ithaca, NY: Cornell University Press, p. 317.

${ }^{141}$ Hayek F.A. (1976) Choice in Currency: a Way to Stop Inflation, London: The Institute of Economic Affairs. URL: https://iea.org.uk/wp-content/uploads/2016/07/upldbook409.pdf. 
дизайна, заранее предопределённого «мудрецами» свыше и заведомо напоминающего, по его мнению, о пороках центрального планирования, которыми, по словам Хайека, и вымощена дорога к рабству ${ }^{142}$.

При создании ЭВС на его институциональном устройстве сказывались разные европейские национальные традиции ведения экономической политики. Такие исторически и институционально укоренённые традиции не исчезли и в новых рамках макроэкономической политики, которая проводится в ЕС сегодня. Но именно в Германии принято было ставить во главу угла цель поддержания ценовой стабильности, подкреплённую независимостью центрального банка ${ }^{143}$. Во Франции, в противоположность этому, приоритет отдавался экономическому правительству (gouvernement économique), т.е. такому взгляду на взаимоотношения между правительством и экономикой, при котором исполнительная власть как раз играет более заметную роль в ежедневном экономическом управлении, активно вмешивается в игру рыночных сил и обеспечивает капитал для инвестирования в крупные проекты $^{144}$.

В наибольшей степени на оформлении институтов валютного союза в Европе до сих пор сказывался ордолиберализм ${ }^{145}$, близкий Фрайбургской школе ${ }^{146}$, корни которого прослеживаются вплоть до 1930 -х годов ${ }^{147}$. Ордолиберальная концепция предусматривает выстраивание таких политико-правовых рамок $(O r d o)$, в которых наиболее эффективно могут проявить себя свободные рыночные силы. Идеи ордолиберализма сформировали социальную рыночную экономику в послевоенной Западной Германии. Ордолиберализм отличается от прочих школ либерализма, включая неолиберализм в той версии, которая преобладает в англо-саксонском мире, тем, что он больший упор делает на предотвращении образования картелей и монополий. В то же время, как и либерализм в принципе, ордолиберы отвергают государственное вмешательство в «нормальный» ход экономического развития. В частности, они выступают против применения проинфляционной фискальной и монетарной политики, которая проводилась бы для стабилизации делового цикла во время спада экономики ${ }^{148}$.

Германский Бундесбанк и многие экономисты в Германии по сию пору придерживаются доктрины ордолиберализма и, напротив, отвергают кейнсианскую альтернативу, способную бросить вызов дискурсу жёсткой экономии ${ }^{149}$. Ордолибералы, в частности, демонстрировали глубокое разочарование взятым германским канцлером Ангелой Меркель в 2010 г. курсом на оказание финансовой помощи странам еврозоны, испытавшим трудности с обслуживанием своих государственных долгов - но лишь до тех пор, пока ей не удалось убедительно представить его как необходимый ответ на угрозу стабильности евро ${ }^{150}$. В целом запрос на политическое вмешательство

\footnotetext{
${ }^{142}$ Hayek F.A. (1978) Denationalization of Money - The Argument Refined, 2nd edn. London: The Institute of Economic Affairs.

143 Подробнее см.: Alessi Ch. (2013) Germany's Central Bank and the Eurozone. URL: https://www.cfr.org/backgrounder/germanys-central-bank-and-eurozone.

144 Jabko N. (2006) Playing the Market: A Political Strategy for Uniting Europe, 1985-2005. Ithaca, NY: Cornell University Press, pp. 168-712

${ }^{145}$ Ordoliberalism and the European Project, 22/04/2015. URL: https://fromtone.com/ordoliberalism-and-the-europeanproject/; Beck Th. and Kotz H.-H., eds. (2017) Ordoliberalism: A German oddity? London: CEPR Press. A VoxEU.org eBook. URL: https://ces.fas.harvard.edu/uploads/files/Reports-Articles/Ordoliberalism-A-German-Oddity-By-HansHelmut-Kotz.pdf.

${ }^{146}$ См.: Теория хозяйственного порядка. "Фрайбургская икола» и немецкий неолиберализм / Под ред. В.П. Гутника - Москва: Экономика, 2002, серия "Экономическое наследие".

147 Худокормов А., Невский С. (2017) Национальные экономические школы в Германии и теория социального рыночного хозяйства // Экономическая политика, том 12. № 4, с. 204-249

${ }^{148}$ Dullien S. and Guérot U. (2012) The long shadow of ordoliberalism: Germany's approach to the euro crisis // ECFR, no 49, February. URL: https://www.ecfr.eu/page/-/ECFR49_GERMANY_BRIEF.pdf.

${ }^{149}$ Young B. (2014) German Ordoliberalism as Agenda Setter for the Euro Crisis: Myth Trumps Reality // Journal of Contemporary European Studies, vol. 22, no. 3, pp. 276-287.

${ }^{150}$ Art David (2015) The German Rescue of the Eurozone: How Germany Is Getting the Europe It Always Wanted // Political Science Quarterly, volume 130, number 2, p. 208. URL: https://as.tufts.edu/politicalscience/sites/all/themes/asbase/assets/documents/art/germanRescueOfTheEurozone.pdf.
} 
для стабилизации экономики в еврозоне противоречит долговременным целям ордолибералов по учреждению в интегрированной Европе правовой системы, принуждающей страны к соблюдению жёсткой бюджетной дисциплины ${ }^{151}$.

Период с момента введения евро до начала мирового финансового кризиса принято считать весьма благоприятным для экономик еврозоны. Объём импорта и экспорта товаров вырос с 1998 по 2007 гг. с 26 до 33\% \% ВВП, а торговля услугами - с 5 до 7\%. Интенсифицировалась торговля стран ЭВС с третьими странами ${ }^{152}$. Снизились и сблизились для стран ЭВС показатели инфляции. Наблюдалось существенное развитие трансграничной финансовой интеграции.

Однако в дальнейшем Европе пришлось иметь дело с крупными кризисами, сотрясавшими европейскую экономику. Первым из них стал мировой финансовый кризис 2008-2009 гг., который она смогла преодолеть относительно быстро. Но на смену ему пришёл европейский долговой кризис, начавшийся в конце 2009 г. с Греции. В кризисных условиях после реализации в 2008-2009 гг. Европейского плана по восстановлению экономики (European Economic Recovery Plan ${ }^{153}$ ) Брюссель обратился к жёстким ограничивающим мерам и пытался воздействовать на разразившийся кризис проциклически ${ }^{154}$.

Ранее подразумевалось, что государства в еврозоне защищены от обвала на финансовом рынке. Под влиянием мирового кризиса некоторые из них (в особенности Греция, Португалия, Ирландия и Испания), ранее переживавшие экономический бум, столкнулись со схлопыванием пузырей на строительном и потребительском рынках, опиравшихся на кредитное финансирование. Последней вспышкой долгового кризиса в Европе стал кипрский кризис в марте-апреле 2013 г., когда радикальной реструктуризации была подвергнута банковская отрасль страны.

Греция оказалась самым «слабым звеном» еврозоны. Кризис нанёс ей удар, от которого она, по большому счёту, не может оправиться по сию пору, но одновременно он выявил проблематичность для еврозоны в целом признания фактического банкротства одной из входящих в неё стран. Первые признаки финансово-экономического кризиса в Греции появились в 2009 г., когда дефицит государственного бюджета в этой стране достиг почти 13\% ВВП, более чем в 4 раза превзойдя установленный в ЕС лимит, а государственный долг превысил 300 млрд. евро (115\% ВВП). Мировые рейтинговые агентства понизили кредитные рейтинги Греции, что отпугнуло инвесторов и подняло для неё стоимость заимствований. В результате страна лишилась шансов самостоятельно найти доступные средства для выплаты накопленного долга. Греция оказалась на грани дефолта, так как не в состоянии была платить по ранее взятым кредитам. Опасаясь дефолта, инвесторы стали продавать греческие государственные облигации, что дополнительно осложнило рефинансирование государственного долга.

В 2010 г., когда масштаб греческой драмы стал окончательно ясен, Европейский центральный банк оказался под жесточайшим политическим прессингом. Лидеры ряда стран ЕС побуждали его отказаться от своей, определённой по договору, «узкой» технократической роли. Но руководство ЕЦБ проявляло осторожность и дальновидность, воздерживаясь от каких-либо собственных экстраординарных действий на рынках долговых обязательств до тех

\footnotetext{
${ }^{151}$ Berghahn V. and Young B. (2013) Reflections on Werner Bonefeld's 'Freedom and the strong state: On German ordoliberalism and the continuing importance of the ideas of Ordoliberalism to understand Germany's (contested) role in resolving the Euro Zone crisis // New Political Economy, vol. 18, no. 5, pp. 768-778.

${ }^{152}$ Baldwin R., Skudelny F. and Taglioni D. (2005) Trade effects from the euro: evidence from sectoral data // European Central Bank, WORKING PAPER SERIES, no 446, February. URL: https://www.ecb.europa.eu/pub/pdf/scpwps/ecbwp446.pdf.

${ }^{153}$ Commission of the European Communities. A European Economic Recovery Plan. Communication from the Commission to the European Council. COM (2008) 800 final. Brussels, 26.11.2008 URL: http://ec.europa.eu/economy_finance/publications/publication13504_en.pdf.

${ }^{154}$ Wolf M. (2014) The Shifts and the Shocks: What We've Learned-And Have Still to Learn-from the Financial Crisis, New York: Penguin, pp. 42-43.
} 
пор, пока государства-члены сами не договорились об отдельной инициативе по оказанию экстренной финансовой помощи Греции и другим, попавшим в беду, странам. Согласно европейским правилам, ЕЦБ не должен монетизировать государственные долги странучастниц, то есть покупать государственные облигации напрямую у правительств, однако нет формального запрета на проведение им операций на вторичном рынке, которыми и стал впоследствии более активно пользоваться ЕЦБ для стабилизации экономики еврозоны.

Чтобы не допустить греческий дефолт, что могло бы подтолкнуть к аналогичному шагу и другие страны еврозоны со слабой экономикой, Афинам были предоставлены кредиты от стран Европейского союза и МВФ - в обмен на обязательство проводить либеральные рыночные реформы и политику жёсткой экономии внутри страны. Помимо Греции, такие страны, как Кипр, Ирландия, Португалия, Испания, столкнувшись с финансовыми трудностями, тоже вынуждены были обратиться за помощью к европейским и международным институтам, составившим так называемую «тройку» (Европейская Комиссия, Европейский центральный банк и Международный валютный фонд).

До тех пор, пока функция оздоровления проблемных банков в ЕС оставалась на национальном уровне, национальные правительства предпочитали сами заниматься и банковским надзором. В согласии с такой ситуацией кредиторами последней инстанции в еврозоне выступали только национальные центральные банки ${ }^{155}$. В период мирового финансового кризиса, начиная с 2007 г., значимость предоставления ликвидности коммерческим банкам в еврозоне существенно возросла. Для отдельных кредитных институтов оно осуществлялось в форме программы экстренной кредитной помощи банкам, испытывающим трудности с фондированием (Emergency Liquidity Assistance - ELA) ${ }^{156}$, осуществляемой через национальные центральные банки, а на макроуровне стала производиться непосредственно через ЕЦБ.

Меры монетарной политики, (в том числе экстраординарные инструменты) ${ }^{157}$ к которым, со своей стороны, прибег ЕЦБ для исправления ситуации, подразделялись на три вида: долгосрочные операции рефинансирования, целевые операции рефинансирования и программы выкупа активов. Долгосрочные операции рефинансирования (Long Term Refinancing Operations - LTRO) - это инструмент предоставления дешевых заёмных средств коммерческим банкам на длительный период (сроком до трёх лет в данном случае) под залог их активов. Механизмом предоставления LTRO является аукцион, проводимый между коммерческими банками. ЕЦБ объявляет сумму, реализуемую через программу LTRO, а коммерческие банки подают заявки с указанной процентной ставкой и ведут конкурентную борьбу за доступную ликвидность. Целевые операции долгосрочного рефинансирования (Targeted Long Term Refinancing Operations - TLTRO) ограничивали банки в использовании получаемых от ЕЦБ заёмных средств (они должны были идти только на кредитование реального сектора экономики). Кроме того, стали производиться нетрадиционные для ЕЦБ покупки гособлигаций стран еврозоны на вторичном рынке на особых условиях (Securities Market Programme, SMP; Outright Monetary Transactions, OMT) и выкуп государственных ценных бумаг, а именно долговых облигаций с инвестиционным рейтингом (так называемое количественное смягчение). ЕЦБ, невзирая на договорные ограничения, был вынужден начать принимать меры, в большей мере присущие национальным центральным банкам. При этом законность проводившихся им «прямых» денежных операций ожесточённо, но безуспешно

\footnotetext{
${ }^{155}$ Padoa-Schioppa T. (1999) "EMU and Banking Supervision", Lecture at the London School of Economics, Financial Markets Group, 24 February. URL: https://www.ecb.europa.eu/press/key/date/1999/html/sp990224.en.html.

${ }^{156}$ CM.: European Central Bank, Eurosystem. Agreement on emergency liquidity Assistance. 17 May 2017. https://www.ecb.europa.eu/pub/pdf/other/Agreement_on_emergency_liquidity_assistance_20170517.en.pdf

${ }_{157}$ См.: Буторина О.В. (2018) Монетарная политика ЕЦБ: новейшие тенденции // Межәународная экономика, № 1, c. 37-49.
} 
оспаривалась оппонентами как не согласующихся с положениями Маастрихтского договора ${ }^{158}$.

Например, согласно условиям программы OMT, предусматривался выкуп ЕЦБ суверенных облигаций проблемных стран еврозоны неограниченного объёма на вторичных рынках - при условии, что эти страны подчинятся жёстким правилам предоставления финансовой помощи по линии Европейского механизма стабильности. Хотя данная программа так и не вступила в действие, наблюдателями была высоко оценена ключевая роль самого по себе объявления о ней (заявленной готовности ЕЦБ к её проведению).

Тем не менее, в 2012 г. группа физических лиц в Германии подала жалобу в Конституционный суд Германии (Peter Gauweiler and Others v Deutscher Bundestag), указав, что объявленная ЕЦБ программа прямых денежных операций (OMT) выходит за рамки данного Банку мандата и нарушает суверенные прерогативы Бундестага. По их мнению, её следовало расценивать как меру экономической политики, куда ЕЦБ запрещено вмешиваться непосредственно. Конституционный суд Германии сначала поддержал аргументы истцов, почитав, что масштаб обязательств, которые вытекали из этой программы, оказался неограниченным и непредсказуемым, но затем передал этот вопрос на рассмотрение в Суд Европейского союза, действуя в рамках преюдициальной процедуры.

В июне 2015 г. Суд ЕС постановил, что программа OMT соответствует мандату ЕЦБ ${ }^{159}$, т.е. дал этому мандату принципиально иную конституционную интерпретацию. Он подтвердил, попутно скорректировав тем самым институциональный дизайн ЕЦБ, заложенный в основополагающем Договоре, что Банк вправе покупать суверенные облигации на вторичном рынке, если это не противоречит цели поддержания ценовой стабильности ${ }^{160}$. Уже в 2014 г. глава ЕЦБ Марио Драги выступил с обоснованием необходимости радикальных изменений в европейской денежно-кредитной политике. По его словам, «с точки зрения спроса, монетарная политика может и должна играть центральную роль, что в настоящее время означает стимулирующую денежную политику, которая будет проводиться продолжительный период времени» ${ }^{161}$.

Количественное смягчение было запущено в еврозоне в 2015 г. в качестве реакции на крайне низкий уровень инфляции (с конца 2012 г. она колебалась в зоне евро на уровне от нуля до $1,5 \%$ годовых ${ }^{162}$. В рамках количественного смягчения ЕЦБ выкупал государственные ценные бумаги на €60 млрд. ежемесячно. С января 2018 г. покупки таких активов были сокращены до €30 млрд. в месяц, с начала октября 2018 ожидается ещё одно сокращение - до $€ 15$ млрд., - в этих пределах покупки продолжатся до конца декабря, а затем могут быть полностью прекращены (при подтверждении благоприятных прогнозов по инфляции). Основная ставка рефинансирования остаётся нулевой (с 2016 г.), ставка по суточным кредитам — на уровне $0,25 \%$, ставка по суточным депозитам — на уровне $-0,4 \%$.

\footnotetext{
${ }^{158}$ Högenauer A.L. and Howarth D. (2016) Unconventional Monetary Policies and the European Central Bank's Problematic Democratic Legitimacy // Journal of Public Law / ZeitschriftfüröffentlichesRecht, vol. 71, no. 2, pp. 425-448.

${ }^{159}$ Fabbrini F. (2016) The European Court of Justice, the European Central Bank, and the Supremacy of EU Law // Maastricht Journal of European and Comparative Law, vol. 23, Issue 1, pp. 3-16. URL: https://papers.ssrn.com/sol3/papers.cfm?abstract_id=2714226\&rec=1\&srcabs=2574233\&alg=1\&pos=6.

${ }^{160}$ Gren J. (2017) How did the ECB become a fully-fledged central bank of the euro zone? February 1. URL: https://rsiblog.blogactiv.eu/2017/02/01/how-did-the-ecb-become-a-fully-fledged-central-bank-of-the-euro-zone/. $C M$. maкже: Pennesi F. (2016) The impossible constitutional reconciliation of the BVerfG and the ECJ in the OMT case. A legal analysis of the first preliminary referral of the BVerfG // Perspectives on Federalism, vol. 8, issue 3,

pp. 1-21. URL: http://www.on-federalism.eu/index.php/articles/248-the-impossible-constitutional-reconciliation-of-thebverfg-and-the-ecj-in-the-omt-case-a-legal-analysis-of-the-first-preliminary-referral-of-the-bverfg.

${ }^{161}$ Unemployment in the euro area. The speech by President Draghi at the Central Bank Symposium in Jackson Hole in August 2014.URL: https://www.ecb.europa.eu/press/key/date/2014/html/sp140822.en.html.

${ }^{162}$ Буторина О. и Цибулина А. (2018) Европейская инфляционная аномалия: источники и риски. 12 апреля. URL: http://russiancouncil.ru/analytics-and-comments/analytics/evropeyskaya-inflyatsionnaya-anomaliya-istochniki-i-riski/.
} 
Зависимость ряда национальных экономик от внешней помощи давала Европейскому центральному банку, который способен был им в этой помощи отказать, мощный рычаг воздействия на национальные правительства. ЕЦБ явочным порядком взял на себя важную роль консультанта правительств, предлагая им советы по вопросам фискальной политики и структурных реформ. Так, в бытность свою главой ЕЦБ Жан-Клод Трише (Jean-Claude Trichet) и некоторые управляющие центральных банков стран еврозоны в ключевые моменты кризиса суверенных долгов неформальным образом направляли правительствам проблемных стран (начиная с Италии и Ирландии) «секретные» письма. В них излагались условия, которые правительства этих стран должны были выполнить в случае своего согласия на получение европейской помощи в той или иной форме ${ }^{163}$.

ЕЦБ давал понять таким странам, что он будет поддерживать их банки только в том случае, если правительства этих стран примут меры жёсткой экономии и будут их придерживаться. Так, в октябре 2010 г. глава ЕЦБ Жан-Клод Трише писал министру финансов Ирландии Брайану Ленихану (Brian Lenihan), предупреждая последнего, что «чрезвычайно масштабное предоставление ликвидности Евросистемой ирландским банкам в последние недели не следует воспринимать как должное», так как в будущем такая поддержка будет определяться, исходя из экономической стратегии правительства Ирландии ${ }^{164}$.

Спустя месяц Трише написал ещё одно письмо тому же адресату, где указал, что Ирландии следует подчиниться программе структурной перестройки, провести оздоровление бюджета и реструктурирование финансового сектора, так как в противном случае предоставление её банкам ликвидности в рамках чрезвычайной помощи будет прекращено ${ }^{165}$. Правительство Италии тоже получило конфиденциальное послание аналогичного плана. В нём говорилось в императивном тоне, что Риму надлежит изменить систему переговоров по заработной плате в стране и реформировать государственный сектор экономики ${ }^{166}$.

В дополнение к рассылке подобных неформальных (и непрошенных) конфиденциальных советов, ЕЦБ получил более формализованную роль консультанта правительств еврозоны через своё участие в «тройке» международных кредиторов (наряду с Европейской комиссией и МВФ). Оно началось весной 2010 г. после принятия первой программы финансовой помощи Греции (хотя Маастрихтский договор вовсе не предусматривал предоставления подобной помощи под определённые условия). С добавлением к «тройке» Европейского механизма стабильности ${ }^{167}$ она впоследствии превратилась в «квадригу».

Программа OMT, объявленная в 2012 г., дополнительно закрепила и обнародовала способность ЕЦБ и других европейских институтов воздействовать на национальную экономическую политику более слабых государств, тогда как ранее давление оказывалось менее публичным, «подковёрным» образом. Теперь ЕЦБ уже совершенно открыто взял на себя роль проводника политика жёсткой экономии. Европейским государствам в этом смысле из солидарности труднее давить друг на друга - поэтому страны-кредиторы, начиная с Германии, предпочитают, чтобы такое (в принципе желаемое ими) давление на должников оказывали не

\footnotetext{
${ }^{163}$ Ирландия стала жертвой шантажа ЕЦБ. 27.08.2012. URL: https:/www.vestifinance.ru/articles/16147.

164 Trichet J-C. (2010a) Letter to Irish Finance Minister Brian Lenihan. 15 October. Available at http://www.ecb.europa.eu/press/html/irish-letters.en.html.

165 Trichet J-C. (2010b) Letter to Irish Finance Minister Brian Lenihan. 19 November. Available at http://www.ecb.europa.eu/press/html/irish-letters.en.html.

${ }^{166}$ ECB letter shows pressure on Berlusconi. September 29, 2011. URL: https:/www.ft.com/content/3576e9c2-eaad11e0-aeca-00144feab49a; Trichet's letter to Rome published, urged cuts. September 29, 2011. URL: https://www.reuters.com/article/us-italy-ecb/trichets-letter-to-rome-published-urged-cuts-idUSTRE78S4MK20110929.

${ }^{167}$ Европейский механизм стабильности (European Stability Mechanism, ESM), о котором ещё пойдёт речь впереди, - это компонент стратегии ЕС по обеспечению финансовой стабильности в еврозоне, постоянный механизм для выполнения заявок испытывающих трудности стран-участниц на получение финансовой помощи, который начал работу в 2012 г.
} 
они, а Банк, продолжающий при этом рядиться в технократические одежды мнимой беспристрастности.

Ограничениям на национальные бюджеты стран-должников, которые «тройка» международных кредиторов накладывала в обмен на предоставление помощи, сопротивлялись национальные парламенты и оппозиционные движения в этих странах. Программы помощи оспаривались в национальных конституционных судах, где были приняты решения, ставящие под вопрос их легитимность ${ }^{168}$, что, в конечном счете, способствовало усилению в странах еврозоны националистических партий, настроенных враждебно по отношению к наднациональному Брюсселю.

Рекордное количество евроскептиков было избрано в ЕП в мае 2014 г. В обстановке не прекращающихся акций протеста трудящихся, у власти в Греции, Италии и Ирландии в 20112012 гг. оказались технократические внепартийные правительства, что свидетельствовало о прискорбных сбоях в национальном демократическом процессе. Расстановка политических сил в ЕС в результате изменилась, вызывая закономерные вопросы о том, какие требуются институциональные реформы, чтобы привести ЭВС в порядок после испытанных потрясений и не ставить при этом впредь под удар демократию в государствах-членах.

Более двадцати пяти лет тому назад руководители Евросоюза приняли решение интенсивно продвигаться в направлении финансовой интеграции в контексте завершения строительства ЕВР. С этим тогда связывались надежды на то, что удастся сделать европейские банки более крупными и конкурентоспособными в глобальном масштабе. Но по факту в результате подобных усилий в Европе оформилась финансовая система, превосходящая пределы демократической ответственности наднациональных институтов, что ярко засвидетельствовали политические обстоятельства финансовых потрясений в Греции, Исландии, Ирландии, Испании и на Кипре в 2008-2013 гг.

Непосредственный разговор об институтах и органах Валютного союза в интегрированной Европе следует продолжить упоминанием о Европейской системе центральных банков - ЕСЦБ (European System of Central Banks, ESCB). Дело в том, что, строго говоря, Европейский центральный банк не является единым центральным банком для Европейского союза, каковой теоретически мог бы быть сформирован путём слияния национальных центральных банков стран ЕС. Взамен подобной централизованной модели на европейском уровне появилась децентрализованная ЕСЦБ. В известном смысле она напоминает Федеральную резервную систему в Соединённых Штатах Америки, где Совет управляющих ФРС связан с местными федеральными резервными банками. Нельзя полностью исключать того, что в процессе дальнейшей интеграции европейская система подвергнется централизации. Однако тот факт, что сейчас ЕСЦБ является децентрализованной, ещё не свидетельствует сам по себе о её неразвитости или переходном характере. Национальные центральные банки в ЕС, скорее всего, сохранятся ещё в течение долгого времени.

У Европейской системы центральных банков нет собственного юридического лица, способности действовать самостоятельно или собственных органов по принятию решений. Но составные части ЕСЦБ \{именно в такой роли выступают ЕЦБ и сохранившиеся национальные центральные банки, в том числе НЦБ тех стран ЕС, которые (пока) не перешли на евро юридическим лицом обладают и действуют в этом смысле как полноценные акторы. При этом, выполняя задачи, которые поручены ЕСЦБ, они обязаны руководствоваться заданными ей ориентирами.

\footnotetext{
${ }^{168}$ Cм., например, Cisotta R. and Gallo D. (2014) The Portuguese Constitutional Court Case Law on Austerity Measures: A Reappraisal // LUISS Guido Carli / Department of Law Working paper, no. 4. URL: https://iris.luiss.it/retrieve/handle/11385/95388/1146/WPG_04-14_Cisotta_Gallo.pdf.
} 
Таким образом, ЕСЦБ составляет общие институциональные рамки, обеспечивая совместное выполнение ЕЦБ и НЦБ некоторых из функций, традиционно присущих центральным банкам. Так как не участвующие в зоне евро государства - члены ЕС сохраняют свой суверенитет в монетарной области, их центральные банки не вовлечены непосредственно в выполнение ключевых функций ЕСЦБ.

ЕЦБ и национальные центральные банки стран еврозоны, в свою очередь, объединены в Евросистему (она будет сосуществовать с ЕСЦБ до тех пор, пока некоторые страны ЕС остаются за пределами еврозоны) и действуют в её рамках, как единая команда. Разделение труда в Евросистеме строится на принципе децентрализации. Его мы должны отличать от принципа субсидиарности, подробно рассмотренного выше. Как мы помним, субсидиарность означает, что потребность в большей централизации при решении в Европейском союзе какихто вопросов должна быть исчерпывающим образом доказана до того, как институты ЕС смогут вступить в действие. Однако денежно-кредитная политика в зоне евро относится к сфере исключительной компетенции Союза и уже не требует подобных предварительных доказательств. Принцип децентрализации в данном случае подразумевает передачу на нижестоящие этажи управления (т.е. на национальный уровень) функций по исполнению решений, которые принимаются на вышестоящем (европейском) уровне. ЕЦБ сам оценивает, в какой мере допустима децентрализация в рамках Евросистемы (т.е. передача исполнительных функций национальным центральным банкам относительно принимаемых ЕЦБ наднациональных решений) в том или ином случае.

Европейский центральный банк отметил собственное двадцатилетие 1 июня 2018 г. С 1 января 1999 г. он проводит единую денежно-кредитную политику на территории стран еврозоны. С 4 ноября 2014 г. Банк также несёт ответственность в рамках Единого механизма по банковскому надзору $(\mathrm{EMH})$ по вопросам, которые касаются политики по пруденциальному надзору над кредитными институтами.

Допустимо утверждение, что ЕЦБ в большей мере независим от политического влияния, чем любой национальный центральный банк мира ${ }^{169}$.Так, если правовая основа существования Федеральной резервной системы (ФРС) в США, Банка Японии, Банка Японии или Центрального банка Российской Федерации может быть изменена парламентским актом, то уставные положения, касающиеся ЕЦБ, с 1992 г. включены в договорную основу («конституцию») ЕС. Сейчас это статьи 3 и 13 Договора о Европейском союзе - ДЕС; статьи 3(1)(c), 119, 123, 127-134, 138-144, 219, а также 282-284 Договора о функционировании Европейского союза - ДФЕС; Протокол №4 к Лиссабонскому договору о Статуте ЕСЦБ Уставе Европейской системы центральных банков и Европейского центрального банка. Договорные положения могут подвергнуться изменению только по единогласному согласию государств-членов Союза с последующей процедурой ратификации в национальных рамках.

ЕЦБ имеет полную самостоятельность в выполнении своего мандата и поставленных перед ним задач. Действующие в его отношении организационные правила запрещают ему принимать прямые политические указания от кого бы то ни было. В частности, в статье 10(4) Устава ЕСЦБ и ЕЦБ говорится о том, что протоколы заседаний Совета управляющих конфиденциальны, хотя можно обнародовать (в ходе пресс-конференции) результаты проходивших на таком заседании обсуждений.

Если главной задачей ЕЦБ является определение и проведение денежно-кредитной политики в зоне евро, то его прочие роли в сумме включают:

\footnotetext{
${ }^{169}$ Amtenbrink F. (1999) The Democratic Accountability of Central Banks: A Comparative Study of the European Central Bank, Oxford and Portland, OR: Hart Publishing.
} 
• надзор над кредитными институтами в Банковском союзе и содействие финансовому оздоровлению проблемных банков в рамках ЕMH;

• общий контроль над макропруденциальной политикой ${ }^{170}$ в рамках Европейского совета по оценке системных рисков (European Systemic Risk Board - ESRB), созданного как часть европейской системы по финансовому надзору;

• участие (на правах консультанта) в разработке и мониторинге программ финансовой помощи странам, поражённым кризисом.

Во внутреннюю структуру управления в ЕЦБ входят четыре органа: Дирекция (Executive Board), Совет управляющих (Governing Council), Общий совет (General Council) и Совет по надзору (Supervisory Board). Дирекция в составе шести человек, прежде всего, отвечает за оперативный менеджмент кредитно-денежной политики в еврозоне в соответствии с указаниями и решениями Совета управляющих, но также плотно вовлечена в формирование курса такой политики. Она осуществляет руководство ЕЦБ и занимается текущими делами Евросистемы. Все члены Дирекции, включая нынешнего главу ЕЦБ итальянца Марио Драги (Mario Draghi) и его заместителя (испанец Луис де Гиндос - Luis de Guindos), назначаются Европейским советом квалифицированным большинством голосов на восьмилетний срок (без права повторно занять свой пост) - после консультаций с Европейским парламентом и Советом управляющих.

Совет управляющих является главным органом ЕЦБ и Евросистемы по принятию решений. Его составляют все члены Дирекции плюс главы центральных банков 19 стран еврозоны (при наличии «своего» члена Дирекции от данной страны она фактически имеет в СУ двух представителей, хотя по форме члены Дирекции обязаны отрешиться в своей работе от учёта национальных интересов). Как правило, заседания Совета управляющих проводятся дважды в месяц. Очередной председатель Совета ЕС и один член Европейской комиссии могут присутствовать на этих заседаниях, но не наделяются при этом правом голоса. Председатель Совета ЕС вправе представить на усмотрение Совета управляющих ЕЦБ своё ходатайство.

Существенно менее влиятелен Общий совет ЕЦБ, объединяющий управляющих 28 центральных банков ЕС, главу ЕЦБ и его заместителя. Он несёт совещательные и координирующие функции и осуществляет подготовительную работу при расширении еврозоны (очередном присоединении к ней стран ЕС - последней к еврозоне на данное время присоединилась Литва в 2015 г.). Общий совет - своего рода переходный орган, призванный выполнять в структуре ЕЦБ задачи третьей стадии построения ЭВС по Маастрихтскому договору (необратимая фиксация обменных курсов). Страны, пока не вошедшие в еврозону, продолжают проводить национальную кредитно-денежную политику и, как уже было сказано, не участвуют в принятии решений, касающихся политики наднациональной.

Совет по надзору ЕЦБ включает председателя, вице-председателя, четырёх представителей ЕЦБ и представителей национальных органов банковского надзора. Он собирается дважды в месяц для обсуждения, планирования и выполнения задач по банковскому надзору в еврозоне. Совет по надзору предлагает проекты соответствующих решений Совету управляющих. Глава Совета по надзору (в настоящее время - Даниэль Нуи Danièle Nouy) назначается на пять лет без права повторного назначения. Организационный комитет (Steering Committee) помогает Совету по надзору в работе и в том числе организует его заседания. В Организационный комитет входят председатель и вице-председатель Совета по надзору, один представитель ЕЦБ и пять представителей национальных органов по надзору.

${ }^{170}$ Относящейся ко всей финансовой системе Европейского союза или к её существенным частям. 
Совет управляющих выступает высшей инстанцией, которая отвечает и за денежнокредитную политику, и за пруденциальный надзор. С одной стороны, теоретически возможна такая ситуация, когда Совету управляющих нужно будет ограничить предоставление ликвидности для решения своей главной задачи - поддержания ценовой стабильности, но одновременно он будет испытывать соблазн предоставить ликвидность банку, чтобы спасти его. Чтобы обойти эту проблему, был создан дополнительный орган, формально отдельный от Совета управляющих, а именно Совет по надзору в рамках ЕMН. Но его решения, по крайней мере формально, всё равно нуждаются в одобрении Совета управляющих.

С другой стороны, обеспеченное на практике довольно жёсткое институциональное разделение функций ЕЦБ в денежно-кредитной сфере и в сфере банковского надзора может и помешать Банку в выполнении его главного мандата (по поддержанию ценовой стабильности). Ведь оно затрудняет получение и обработку Банком информации, которая помогала бы в полной мере понять, как предпринимаемые им меры в денежно-кредитной области влияют на банковское кредитование и риски, с ним связанные. Из-за барьеров между ними, в известном смысле искусственных, его деятельность по банковскому надзору и денежно-кредитные операции могут оказаться в результате недостаточно скоординированными ${ }^{171}$.

Европейский совет по оценке системных рисков, в котором центральное место отведено ЕЦБ (он оказывает ЕССР аналитическую поддержку) и который в настоящее время возглавляет глава ЕЦБ, собирает информацию, идентифицирует и анализирует системные риски, обеспечивая «раннее оповещение» о нарастании системных (взаимосвязанных, комплексных, отраслевых и межотраслевых) рисков в финансовой системе ЕС. При необходимости ЕССР даёт рекомендации правительствам о том, как с ними справляться ${ }^{172}$. При этом в рамках ЕМН у ЕЦБ пока ограниченные полномочия в макропруденциальной сфере ${ }^{173}$, хотя в дальнейшем они могут и расшириться, распространившись, например, на такие вопросы, как рынок теневого банкинга или клиринг по сделкам с деривативами.

Уже после создания в 2010 г. ЕССР государства - члены Европейского союза учредили национальные органы макропруденциального надзора, зачастую с более весомыми полномочиями, чем у самого ЕССР, поскольку конкретные меры макропруденциальной политики в ЕС, из-за различий в деловых и финансовых циклах в государствах-членах, как правило, требуются именно на национальном уровне. В 2014 г. на ЕССР была дополнительно возложена роль по координации некоторых из макропруденциальных инструментов ${ }^{174}$,

\footnotetext{
${ }^{171}$ Kern A. (2017) The European Central Bank's supervisory powers: the need for enhanced macro-prudential supervision // Zurich Open Repository and Archive, pp. 349-350. URL: http://www.zora.uzh.ch/id/eprint/149183/1/Alexander_ECB_Legal_Conference_Eproceedings_201712.pdf.

172 О системе регулирования финансовых рынков в ЕС см., например, Пашкевич А. и Власенко М. (2017) Инструменты макропруденциальной политики: европейский опыт, перспективы для Беларуси // Банкаўскі веснік, май, с. 4-7. URL: https://www.nbrb.by/bv/articles/10385.pdf.

${ }_{173}$ Мандат ЕЦБ в макропруденциальной сфере опирается на статью 5(2) Регламента о EMH. ESM Regulation: Council Regulation (EU) No1024/2013 of 15October 2013 conferring specific tasks on the European Central Bank concerning policies relating to the prudential supervision of credit institutions (OJ L287, 29.10.2013, р.63). Подробнее см.: Kern А. (2017) Ibid., pp. 349-413.

174 Макропруденциальные инструменты - это меры финансовой политики, помогающие справляться с системными рисками (например, ограничения в отношении стандартов кредитования, требования по ликвидности, лимиты на активные рисковые банковские операции и прочее). Подробнее см.: Lim C., Columba F., Costa A., Kongsamut P., Otani A., Saiyid M., Wezel T., and Wu X. (2011) Macroprudential Policy: What Instruments and How to Use Them? Lessons from Country Experiences // IMF Working Paper, no. 238. URL: https:/www.imf.org/external/pubs/ft/wp/2011/wp11238.pdf. Задача макропруденциального анализа заключается в выявлении потенциальных проблем, способных поразить финансовую систему в целом. Индикаторы финансовой устойчивости могут также использоваться при изучении макрофинансовых взаимосвязей для выявления воздействия на экономику разнообразных шоков, которое происходит через финансовую систему страны. См. также: Андрюшин С., Кузнецова В. (2012) Инструменты макропруденциальной политики центральных банков // Вопросы экономики, №8. М.: «Редакция журнала «Вопросы экономики»»), с.32-47.
} 
предусмотренных в европейском или национальном законодательстве. По регламенту о ЕМН от 2013 года национальные власти вправе сами вводить новые меры макропруденциальной политики, а ЕЦБ - только усиливать те меры, которые уже были ранее оговорены в законодательстве ЕС. Несмотря на гармонизацию в ЕС многих норм регулирования, в применении макропруденциальных инструментов в отдельных европейских странах попрежнему сохраняется заметный разнобой.

Для реализации возложенных на него задач по линии денежно-кредитной политики, а также банковского надзора ЕЦБ (точнее, Совет управляющих, который собирается во Франкфурте-на-Майне, Германия) издаёт наднациональные регламенты и принимает решения, обязательные для исполнения в национальных рамках. При неисполнении или недолжном исполнении на национальном уровне подобных решений Совет вправе обратиться в Суд ЕС. Кроме того, ЕЦБ может выносить рекомендации и заключения, которые не имеют юридической силы.

Совет управляющих обычно голосует простым большинством, а при равном количестве голосов «за» и «против» того или иного решения глава ЕЦБ получает решающий голос. В момент создания ЕЦБ каждый член Совета управляющих имел один постоянный голос. Когда общая численность его членов превысила 24 с учетом 6 членов Дирекции (в настоящее время в СУ всего 25 членов), число управляющих национальных центральных банков с правом голоса в каждый данный момент было сокращено до 15. Таким образом, для укрепления работоспособности Совета управляющих, в условиях расширения его численности, был введён «ротационный механизм», при наличии которого перечень голосующих стран ежемесячно меняется.

С этого времени национальные управляющие распределены в Совете по двум группам, а по достижении Советом общей численности в 28 членов (при дальнейшем расширении еврозоны) будут распределяться по трём группам. Но вероятность того, что это может произойти в ближайшем будущем, следует признать довольно низкой.

Распределение поставлено в зависимость от доли конкретной страны в совокупном ВВП Евросоюза и от величины их финансового сектора. В первую группу входят Германия, Франция, Италия, Испания и Нидерланды, которые делят между собой 4 голоса. Во второй группе оказались остальные страны еврозоны (общим числом 14), у которых совокупно 11 голосов. Участники каждой из групп пользуются правом голоса в порядке ротации внутри своей группы по определённой схеме. В таблице 2-1 приведено расписание, составленное на 2019 г. Таблица 2-2 даёт представление о частоте участия в голосовании стран первой и второй группы на настоящем этапе (при численности Совета управляющих от 19 до 27 членов) и впоследствии. При этом система ротации не распространяется на членов Дирекции, которые сохраняют полный голос.

Очевидно, что введённая система, прежде всего, выгодна членам Дирекции, которые при нынешней численности Совета управляющих получают 28,6\% голосующих голосов (6 из $21)$ против $24 \%$ (6 из 25) - при условии сохранения прежних правил. Группа экономически мощных стран получает $19 \%$ голосов против $20 \%$ по прежним правилам, а страны из второй группы - 52\% против 56\%.

Таким образом, независимость ЕЦБ охватывает следующие аспекты:

-- институциональная независимость (Европейскому центральному банку нельзя получать или испрашивать инструкции ни от какого органа, будь то публичного или частного, что не исключает информационного обмена с такими органами или диалога с ними;

-- правовая независимость (включает право ЕЦБ обращаться в Суд ЕС, чтобы отстоять свои прерогативы, если им нанесён ущерб каким-то институтом ЕС или государством-членом); 
-- персональная независимость членов органов ЕЦБ, ответственных за принятие его решений (для этого в частности, предусмотрены довольно длительные сроки пребывания в должности ${ }^{175}$ );

-- функциональная независимость (в частности, ЕЦБ запрещено напрямую кредитовать публичный сектор, что защищает его от давления государственных и европейских властей);

-- финансовая и организационная независимость (у ЕЦБ и НЦБ есть собственные финансовые ресурсы и доходы; ЕЦБ организует свою внутреннюю структуру по собственному усмотрению).

Таблица 2-1

График голосования в Совете управляющих на 2019 г.

\begin{tabular}{|c|c|c|c|c|c|c|c|c|c|c|c|c|}
\hline \multirow{2}{*}{ Управляющие национальных центральных банков } & \multicolumn{12}{|c|}{ Месяц } \\
\hline & 1 & 2 & 3 & 4 & 5 & 6 & 7 & 8 & 9 & 10 & 11 & 12 \\
\hline $\begin{array}{l}\text { Йенс Вайдман (Jens Weidmann), Немецкий } \\
\text { федеральный банк (Бундесбанк) }\end{array}$ & & & & $X$ & & & & & 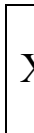 & & & \\
\hline $\begin{array}{l}\text { Луис Мария Линде (Luis María Linde), Центральный } \\
\text { банк Испании }\end{array}$ & & & & & $X$ & & & & & $\mathrm{X}$ & & \\
\hline $\begin{array}{l}\text { Франсуа Виллеруа де Гало (FrançoisVilleroydeGalhau), } \\
\text { Центральный банк Франции }\end{array}$ & $\mathrm{X}$ & & & & & $X$ & & & & & $\mathrm{X}$ & \\
\hline Иньяцио Виско (Ignazio Visco), Банк Италии & & $\mathrm{X}$ & & & & & $\mathrm{X}$ & & & & & $\mathrm{X}$ \\
\hline $\begin{array}{l}\text { Клаас Нот (Klaas Knot), Центральный банк } \\
\text { Нидерландов }\end{array}$ & & & $X$ & & & & & $X$ & & & & \\
\hline
\end{tabular}

\footnotetext{
175 Упомянем здесь минимальный срок в пять лет для управляющих НЦБ (они по должности входят в Совет управляющих ЕЦБ), с возможностью повторного назначения, и срок в восемь лет для членов Дирекции - без такой возможности, причём никто из них не может быть уволен из-за предположительно неудовлетворительного выполнения соответствующих обязанностей. Основанием для увольнения может послужить только их несоответствие условиям выполнения этих обязанностей или признание их виновными в достаточно серьёзном проступке. К примеру, в феврале 2018 г. глава Центробанка Латвии Илмар Римшевич был официально отстранён от своей должности национальным Бюро по предотвращению коррупции по подозрению в вымогательстве и получении взятки. См.: https://www.novayagazeta.ru/articles/2018/02/20/75575-glavu-tsentrobanka-latvii-obvinyayutv-korruptsii-i-vozmozhnyh-svyazyah-s-rossiey. Однако юридически Римшевич по-прежнему продолжал занимать эту должность, будучи членом Совета управляющих ЕЦБ. Действия в Латвии в его отношении могли рассматриваться в ЕС как покушение на независимость ЕЦБ. См.: http://rus.delfi.lv/news/daily/latvia/danarejzniece-ozola-smestit-ilmara-rimshevicha-bez-uchastiya-ecb-prakticheski-nevozmozhno.d?id=49774503. ЕЦБ обратился в Суд ЕС для принятия им решения, не противоречат ли действия, предпринятые в Риге в отношении Римшевича, европейскому законодательству, запросив ускоренное рассмотрение дела, чтобы прояснить ситуацию в течение четырех-шести месяцев.
} 


\begin{tabular}{|l||l|||}
\hline Ян Сметс (Jan Smets), Национальный банк Бельгии & \\
\hline Ардо Ханссон (Ardo Hansson), банк Эстонии & \\
\hline Филип Лейн (Philip Lane), Центральный банк \\
Ирландии
\end{tabular}

Источник: https://www.ecb.europa.eu/ecb/orga/decisions/govc/html/votingrights.en.html.

Оборотной стороной высокой меры независимости, дарованной в 1990-е годы Европейскому центральному банку, была подразумеваемая узость его мандата (банк и сам предпочитал отвечать только или главным образом за поддержание ценовой стабильности). Продвигать общую экономическую политику в Союзе ЕЦБ мог только в той мере, в какой это 
выполнению его мандата не угрожало ${ }^{176}$. Роль ЕЦБ была специально прописана таким образом, чтобы его решения не могли иметь очевидных распределительных последствий.

Создание независимого ЕЦБ явилось в своё время частью более широкой международной тенденции, поскольку в 1980-х и 1990-х годах идея независимости центральных банков обрела прочное академическое признание. В Европе большое благоприятное впечатление произвёл ранее успех Бундесбанка Западной Германии в обеспечении ценовой стабильности в период стагфляции в 1970-е годы.

Необходимо отметить, что делегированная организационная форма осуществления исполнительной, по своей сути, власти ${ }^{177}$, пусть и не столь радикальная, ныне является нормой для центральных банков по всему миру. Такая норма опирается на утвердившиеся и имеющие определённую идеологическую основу представления о том, что центральные банки лучше изолировать от считающихся вероятными попыток политиков стимулировать экономику из электоральных соображений в ущерб её долговременному развитию и стабильности. Обеспеченная органам принятия решений в ЕЦБ независимость изначально призвана была позволить им полнее сконцентрироваться на сохранении покупательной способности евро через поддержание ценовой стабильности.

Таблица 2-2

Схема голосования в Совете управляющих (на нынешнем этапе и на перспективу)

\begin{tabular}{|c|c|c|c|c|c|c|c|c|c|}
\hline \multirow{2}{*}{$\begin{array}{l}\text { Общее число } \\
\text { управляющих }\end{array}$} & \multicolumn{3}{|c|}{ Первая группа } & \multicolumn{3}{|c|}{ Вторая группа } & \multicolumn{3}{|c|}{ Третья группа } \\
\hline & Управл. & Голоса & Голосования & Управл. & Голоса & Голосования & Управл. & Голоса & Голосования \\
\hline \multicolumn{10}{|c|}{ При численности еврозоны от 19 до 21 страны } \\
\hline 19 & 5 & 4 & $80 \%$ & 14 & 11 & $79 \%$ & & & \\
\hline 20 & 5 & 4 & $80 \%$ & 15 & 11 & $73 \%$ & & & \\
\hline 21 & 5 & 4 & $80 \%$ & 16 & 11 & $69 \%$ & & & \\
\hline \multicolumn{10}{|c|}{ При численности еврозоны от 22 до 27 стран } \\
\hline 22 & 5 & 4 & $80 \%$ & 11 & 8 & $73 \%$ & 6 & 3 & $50 \%$ \\
\hline 23 & 5 & 4 & $80 \%$ & 12 & 8 & $67 \%$ & 6 & 3 & $50 \%$ \\
\hline 24 & 5 & 4 & $80 \%$ & 12 & 8 & $67 \%$ & 7 & 3 & $43 \%$ \\
\hline 25 & 5 & 4 & $80 \%$ & 13 & 8 & $62 \%$ & 7 & 3 & $43 \%$ \\
\hline 26 & 5 & 4 & $80 \%$ & 13 & 8 & $62 \%$ & 8 & 3 & $38 \%$ \\
\hline 27 & 5 & 4 & $80 \%$ & 14 & 8 & $57 \%$ & 8 & 3 & $38 \%$ \\
\hline
\end{tabular}

Источник: Rotation of Voting Rights in the Governing Council of the ECB // ECB Monthly Bulletin, July 2009. P. 93. URL: https://www.ecb.europa.eu/pub/pdf/other/mb200907_pp91-99en.pdf?a90d434e1d008b5f1 eb64e11f9bb3ab7

В 1998 г. было принято и в 2003 г. уточнено определении ценовой стабильности для еврозоны как уровня инфляции, который ниже, но близок к $2 \%$ в среднесрочной перспективе

\footnotetext{
${ }^{176}$ СТ. 127(1) ДФЕС.

${ }^{177}$ Cм. McNamara Kathleen R. (2005) Economic and Monetary Union: Innovations and Challenges for the Euro // PolicyMaking in the European Union /Ed. by Helen Wallace, William Wallace and Mark Pollack - Oxford: Oxford University Press, p 154.
} 
(так называемый гармонизированный индекс потребительских цен). В итоге деятельность ЕЦБ оказалась более прозрачна для оценки, чем у ФРС и Банка Японии. Ведь они не ориентированы на точное количественное определение ценовой стабильности. В то же время действия ЕЦБ не столь транспарентны, как у Банка Англии, где взят однозначный целевой уровень потребительских цен в $2 \%$ (точечный таргет годовой инфляции, принятый на постоянной основе $)^{178}$. Исключительная важность, которая придавалась в ЕЦБ поддержанию ценовой стабильности, позволила некоторым авторам причислить его к «консервативным центральным банкам» ${ }^{179}$.

Но сразу после создания Европейского союза наблюдатели стали выражать беспокойство в отношении демократической легитимности процесса углубления экономической интеграции, в котором столь большая роль была отведена технократам, не несущим политической ответственности за свои действия. В еврозоне демократический дефицит особенно увеличился ввиду уставной независимости ЕЦБ и применения программ финансовой помощи под управлением «тройки» международных кредиторов, которые уже были упомянуты.

Одновременно с тем в Маастрихтском договоре были предусмотрены меры, заставляющие ЕЦБ отчитываться за свои действия. Ведь одним из фундаментальных принципов в обществах с демократическими режимами является то, что всякий независимый институт, наделенный публичными функциями, должен давать отчет гражданам и их избранным представителям по поводу проводимого им курса. Таким образом, отчётность должна быть важным противовесом независимости ЕЦБ ${ }^{180}$, который призван обеспечить, чтобы его независимость не обернулась ничем не ограниченной свободой действий.

Евросистема ежедневно публикует обобщенный комментарий по финансовым вопросам. Деятельность Евросистемы является также предметом ежеквартально публикуемых отчетов. ЕЦБ обязан готовить (в режиме добровольного раскрытия информации) ежегодный доклад по денежно-кредитной политике (как и по другим направлениям своей деятельности) для Европейского совета, Комиссии, Совета министров и Европейского парламента. Кроме того, глава ЕЦБ не реже одного раза в год выступает на пленарном заседании ЕП и раз в квартал - в среднем на два часа появляется в парламентском комитете по экономическим делам и финансовой политике (чтобы сделать вступительное заявление и ответить на вопросы в рамках Монетарного диалога) ${ }^{181}$. Прочие члены Дирекции тоже выступают в ЕП, когда там рассматриваются имеющие отношение к сфере ответственности ЕЦБ специальные проблемы. Ответы ЕЦБ на письменные вопросы европарламентариев публикуются в Официальном журнале Евросоюза ${ }^{182}$ и на сайте ЕЦБ ${ }^{183}$. Но если Комиссию Европарламент вправе отправить в отставку в полном составе, то аналогичной власти в отношении Совета управляющих ЕЦБ он не имеет.

Для сравнения: в США председатель Совета управляющих Федеральной резервной системы регулярно выступает в Конгрессе с пояснениями, как проводимая ФРС политика согласуется с целями, которые определяет Конгресс. Действенность механизмов подотчётности в данном случае подкреплена тем, что Конгресс способен на правовые действия, преобразующие или даже упраздняющие ФРС. Европейский парламент не мог бы

178 Для сравнения: Банк России действует в рамках режима таргетирования инфляции, определяя количественную цель по инфляции на среднесрочную перспективу.

${ }^{179}$ CM. Hodson D. (2010) Economic and monetary Union: an Experiment in New Mode of EU Policy-Making // PolicyMaking in the European Union, Sixth edition, Oxford: Oxford University Press, p. 166.

${ }^{180}$ Подробнее об основных каналах, используемых ЕЦБ для информирования общественности, см.: Европейский центральный банк. Денежно-кредитная политика ЕЦБ. Франкфурт на Майне, 2004, с. 86-87.

181 ЕЦБ также подлежит организационному контролю со стороны внешнего аудитора и Палаты аудита ЕС, как и Европейского бюро по борьбе с мошенничеством (European Anti-Fraud Office - OLAF).

${ }^{182} \mathrm{http}: / /$ eur-lex.europa.eu/JOIndex.do.

${ }^{183} \mathrm{http}: / /$ www.ecb.int/home/html/index.en.html. 
претендовать на столь серьёзное влияние. ЕП не представляет единый электорат (демос). Европейские парламентарии избираются от национальных избирательных округов. Довольно логично поэтому, что ЕП не вправе ликвидировать или подвергнуть взысканию Совет управляющих ЕЦБ, т.е. европейский наднациональный технократический орган, который к тому же формируется не на основании его решения.

В то же время независимость ЕЦБ в вопросах денежно-кредитной политики неоправданно было бы в полной мере распространять на выполнение им функций по банковскому надзору (эта тема более подробно раскрыта в следующей главе настоящей монографии). Оговоримся, что сфера банковского надзора в ЕС в настоящее время регулируется не межправительственным договором, но наднациональным регламентом ${ }^{184}$, на основании которого за выполнение своих надзорных задач ЕЦБ отчитывается перед ЕП, Советом министров ЕС и национальными парламентами. Он составляет ежегодный отчёт о своей деятельности по банковскому надзору. Этот отчёт должен быть представлен Европейскому парламенту в ходе открытых слушаний. Этот доклад также представляется Комиссии и Еврогруппе. Комитет ЕП по экономике может приглашать главу Совета ЕЦБ по банковскому надзору на слушания по вопросам исполнения Банком надзорных функций. Но в регламенте отсутствует упоминание конкретных целей или стандартов, на основании которых надзорная деятельность ЕЦБ могла бы оцениваться сколько-нибудь предметнее.

В сфере пруденциального надзора, в отличие от кредитно-денежной политики, у европейской легислатуры (но лишь у Совета, действующего единогласно ${ }^{185}$ ) есть право внесения изменений в законодательство, касающееся деятельности ЕЦБ. В этом есть явное отличие по сравнению с квазиконституционным статусом правовых и институциональных положений, которые касаются денежно-кредитной политики, будучи закреплены в основополагающем договоре. У ЕП, в свою очередь, здесь заметная роль при назначении и увольнении председателя и заместителя председателя Комитета по банковскому надзору (но, как уже было упомянуто, не вышестоящего Совета управляющих ЕЦБ). Для сравнения форм подотчётности ЕЦБ в области денежно-кредитной политики и банковского надзора далее приведена таблица 2-3.

Наконец, Ансгар Белке полагает, что оптимальная степень секретности в действиях ЕЦБ в любом случае не должна равняться нулю. Ведь полная отчётность и демократический контроль со стороны ЕП могут помешать ЕЦБ должным образом выполнять свои обязанности, если группы европарламентариев разной политической или идеологической ориентации начнут настаивать на принятии ЕЦБ конкретных макроэкономических моделей или даже определённых мер в денежно-кредитной политике ${ }^{186}$.

В собственном подходе к необходимости совершенствования отчётности Банк подчёркивает свою высокую транспарентность и готовность вступать в диалог, соответствие требованию публично обосновывать и объяснять свои решения. Руководство Банка отвергает критику в свой адрес, указывая, что оно делает в плане обеспечения прозрачности даже больше того, что формально требует европейское право, регулярно проводит прессконференции и выпускает пресс-релизы, а также публикует статистику и прогнозы.

Действительно, с 2015 г. обнародуется содержание дискуссий, которые завязываются на заседаниях Совета управляющих ЕЦБ, посвящённых денежно-кредитной политике. На сайте Банка публиковались решения и изложение процедур, касающихся $E L A$. Глава ЕЦБ

\footnotetext{
184 Council Regulation (EU) No 1024/2013. URL: $\underline{\text { https://eur-lex.europa.eu/legal- }}$ content/EN/TXT/?uri=CELEX\%3A32013R1024.

${ }_{185}$ Регламент о ЕМН был принят на основании статьи 127(6) ДФЕС, в силу чего при его изменении должна действовать особая законодательная процедура.

${ }^{186}$ Belke A. (2014) Monetary dialogue 2009-2014: Looking backward, looking forward // ROME Discussion Paper Series, No. 14-02, Forschungsnetzwerk 'Research on Money in the Economy' (ROME), Düsseldorf, p. 8. URL: https://www.econstor.eu/bitstream/10419/98657/1/785490760.pdf.
} 
Таблица 2-3

Подотчётность ЕЦБ в области денежно-кредитной политики и банковского надзора

\begin{tabular}{|c|c|c|}
\hline $\begin{array}{c}\text { Механиз- } \\
\text { мы }\end{array}$ & $\begin{array}{c}\text { Денежно-кредитная } \\
\text { политика }\end{array}$ & Банковский надзор \\
\hline $\begin{array}{l}\text { Назначение } \\
\text { руководства }\end{array}$ & $\begin{array}{l}\text { Европейский совет } \\
\text { назначает Дирекцию ЕЦБ } \\
\text { квалифицированным } \\
\text { большинством после } \\
\text { консультации с ЕП }\end{array}$ & $\begin{array}{l}\text { Председатель Совета по надзору и его } \\
\text { заместитель назначаются Советом } \\
\text { министров ЕС и ЕП по предложению } \\
\text { Совета управляющих (требуется } \\
\text { одобрение парламентского комитета по } \\
\text { экономике и ЕП в целом) }\end{array}$ \\
\hline $\begin{array}{l}\text { Увольнение } \\
\text { руководства }\end{array}$ & $\begin{array}{l}\text { Суд ЕС может отправить } \\
\text { членов Дирекции в } \\
\text { отставку по запросу Совета } \\
\text { управляющих или самой } \\
\text { Дирекции }\end{array}$ & $\begin{array}{l}\text { У ЕП есть право одобрить отставку главы } \\
\text { Комитета по надзору и его заместителя }\end{array}$ \\
\hline $\begin{array}{l}\text { Ежегодный } \\
\text { отчёт: куда } \\
\text { направляется? }\end{array}$ & $\begin{array}{l}\text { Направляется в ЕП, } \\
\text { Комиссию, Совет и } \\
\text { Европейский совет }\end{array}$ & $\begin{array}{l}\text { Направляется в ЕП, Комиссию, в Совет, } \\
\text { Еврогруппу, а также национальным } \\
\text { парламентам стран еврозоны }\end{array}$ \\
\hline $\begin{array}{l}\text { Представление } \\
\text { ежегодного } \\
\text { отчёта: кем } \\
\text { представляет } \\
\text { ся? }\end{array}$ & $\begin{array}{l}\text { Глава ЕЦБ представляет } \\
\text { отчёт в ЕП }\end{array}$ & $\begin{array}{l}\text { Глава Совета по банковскому надзору } \\
\text { представляет отчёт ЕП и Еврогруппе }\end{array}$ \\
\hline $\begin{array}{l}\text { Запрос об } \\
\text { открытых } \\
\text { слушания со } \\
\text { стороны ЕП и } \\
\text { Еврогруппы }\end{array}$ & $\begin{array}{l}\text { ЕП может } \\
\text { консультироваться с главой } \\
\text { ЕЦБ и другими членами } \\
\text { Дирекции }\end{array}$ & $\begin{array}{l}\text { ЕП и Еврогруппа могут запросить } \\
\text { проведение слушаний с главой Совета по } \\
\text { банковскому надзору }\end{array}$ \\
\hline $\begin{array}{l}\text { Ответы на } \\
\text { вопросы } \\
\text { парламента } \\
\text { риев }\end{array}$ & $\begin{array}{l}\text { Ежеквартальный } \\
\text { монетарный диалог } \\
\text { Члены ЕП могут } \\
\text { направлять вопросы ЕЦБ }\end{array}$ & $\begin{array}{l}\text { ЕЦБ в письменном или устном виде } \\
\text { отвечает на вопросы членов ЕП, } \\
\text { национальных парламентов и Еврогруппы }\end{array}$ \\
\hline $\begin{array}{l}\text { Запрос } \\
\text { закрытых } \\
\text { слушаниях со } \\
\text { стороны } \\
\text { представитель } \\
\text { ной власти }\end{array}$ & Нет & $\begin{array}{l}\text { Глава и заместитель главы комитета ЕП по } \\
\text { экономике могут запросить о встрече с } \\
\text { председателем Совета по надзору, } \\
\text { который, со своей стороны, обязан } \\
\text { «сотрудничать» с расследованиями ЕП }\end{array}$ \\
\hline $\begin{array}{l}\text { Участие } \\
\text { заседаниях } \\
\text { органов ЕЦБ }\end{array}$ & \multicolumn{2}{|c|}{$\begin{array}{l}\text { Представителей Совета министров ЕС и Комиссии приглашают на } \\
\text { заседания Совета управляющих ЕЦБ (без предоставления им права } \\
\text { голоса и при условии соблюдения ими строгой конфиденциальности) }\end{array}$} \\
\hline
\end{tabular}

Источник: законодательство ЕС 
Марио Драги систематически посещает национальные парламенты стран еврозоны с целью обоснования проводимой Банком политики. Состоялись такие визиты в Германию (2012 г), Испанию (2013г.), Францию (2013 г.), Финляндию (2014 г.), Италию (2015 г.) и Нидерланды (2017 г.). Вместе с тем, выступая на заседании французской Национальной ассамблеи в 2013 г., Марио Драги признал, что продолжающееся наращивание власти Европейского центрального банка требует «большей демократической легитимности», в чём Европейскому парламенту и национальным парламентам должна принадлежать важнейшая роль» ${ }^{187}$.

Но подотчётность вряд ли следует ограничивать одной только транспарентностью. Она требует более углубленного обсуждения возникающих вопросов с теми, кто критикует действия ЕЦБ. Учтём, что опыт проведения «нетрадиционной» европейской денежнокредитной политики (включая $E L A$ ) и действия ЕЦБ как советника правительств были фактически засчитаны в ЕС в качестве части его «законной» компетенции. Получается, что они не требуют дополнительной отчётности, несмотря на их очевидные фискальные и дистрибутивные последствия. Тем более вызывает сомнения, что дарованная ЕЦБ степень независимости должна быть практически в равной мере распространена и на выполнение им функций по банковскому надзору.

Мировой финансовый кризис, начавшийся в 2008 г., обнажил структурные изъяны в институциональной архитектуре еврозоны. Оборотной стороной высокой меры независимости ЕЦБ была узость его мандата (он отвечал только за ценовую стабильность). Поддерживать общую экономическую политику в Союзе Банк был вправе только в той мере, в какой это не угрожало выполнению этого мандата. Ставя ценовую стабильность превыше всего, ЕЦБ не имел возможности, скажем, уделить приоритетное внимание борьбе с безработицей. Но если в первую десятилетку работы Банка развитые страны мира, включая Европу, имели положительные и стабильные темпы роста, а также низкие уровни инфляции, то после кризиса главной угрозой для их экономики стала уже не инфляция, а дефляция.

Хотя ЕЦБ сыграл ключевую роль в спасении еврозоны в период кризиса суверенных долгов, ползучее расширение его компетенций вряд ли следовало бы просто принять к сведению. Методы обеспечения подотчётности Банка, за исключением некоторых второстепенных частностей, по большому счёту, почти не изменились - в отличие от его расширившейся компетенции. Они сосредоточены вокруг обеспечения прозрачности его деятельности, при котором демократическим институтам отводится, скорее, пассивная роль получателей той информации, которую им сочтут возможным предоставить, а также Монетарного диалога между ЕЦБ и ЕП, эффективность которого, по меньшей мере, небесспорна.

Пертурбации в еврозоне в 2010-е годы подвергли жестокому испытанию политическую систему Европейского союза. С ними оказались связаны вопросы нормативной легитимности. Это произошло и потому, что Европейский союз как таковой представляет собой нормативный порядок (включающий принципы и ценности, определяющие нормы поведения для государств-членов и европейских институтов), и в силу того, что собственно валютная интеграция в Европе во многом опиралась на либеральную экономическую теорию, которая подчёркивает нормативную значимость деполитизации денег.

Между тем у легитимности есть два аспекта: не только формальный, но и общественный. Согласно формальной стороне дела, для создания независимого центрального банка требуется конституционное решение или положение межправительственного договора. С общественной точки зрения легитимность имеет большее отношение к поддержке институтов со стороны общества. Она определяется их признанием или лояльностью общества по отношению к политической системе.

\footnotetext{
${ }^{187}$ Draghi M. (2013). Introductory remarks at the French Assemblée Nationale. Speech by Mario Draghi, President of the ECB, Paris, 26 June 2013. Available at: https://www.ecb.europa.eu/press/key/date/2013/html/sp130626.en.html.
} 
Центральные банки регулируют уровни роста цен, что крайне важно для общества. Дарованная им независимость в данном случае - это только инструмент для достижения какой-то цели или набора целей. Соответственно, важность избранной цели должна быть ключевым соображением при выборе адекватных правовых рамок для её достижения. Если цель серьёзно оспаривается в обществе, то под вопросом оказываются политика, которую проводит центральный банк, а также его действия или решения по достижению данной цели - например, количественное смягчение и другие нетрадиционные инструменты денежнокредитной политики, направленные на поддержание финансовой стабильности «любой ценой».

При фактически расширенном мандате центральным банкам требуются новые механизмы подотчётности ${ }^{188}$, которая важна в первую очередь для предотвращения случаев злоупотребления властью. Если мандат банка становится более размытым, широким и сложным, многокомпонентным, если его функции включают проведение нетрадиционной монетарной политики и акцент на поддержание финансовой стабильности, то прежний консенсус вокруг целей ЕЦБ распадается и реальная значимость его независимости неизбежно идёт на убыль ${ }^{189}$.

Делегирование центральному банку функций банковского надзора и задач по поддержанию финансовой стабильности в таком смысле выглядят более проблематично, нежели таргетирование инфляции, потому что последнее проще подвергнуть мониторингу. В любом случае ясно, что при расширенном мандате баланс между независимостью и подотчётностью ЕЦБ следует сдвинуть в сторону подотчётности, не смешивая последнюю с транспарентностью. Последовательная пдотчётность позволяла бы Центральному банку представить обществу убедительное оправдание собственных действий в каждом конкретном случае, хотя в то же время слишком жёсткая подотчётность может составить угрозу эффективности действий ЕЦБ.

В Экономическом и валютном союзе формальная легитимность «на входе» заключена в самом акте делегирования денежно-кредитной политики Европейскому центральному банку на основании Маастрихтского договора, который был единогласно принят всеми правительствами государств-членов и должным образом ратифицирован. Государства-члены, действуя через своих избранных гражданами представителей, приняли суверенное решение передать ответственность за монетарную политику и связанные с ней задачи этому вновь созданному институту Европейского союза. Кроме того, легитимность ЕЦБ «на входе» некоторым образом подкреплена процедурой назначения членов его руководящих органов (назначение производят представители государств-членов, которые сами пришли к власти в собственных странах демократическим путём). Напомним, что Дирекция назначается Европейским советом (после консультаций с ЕП), а другие члены Совета управляющих ЕЦБ - собственными национальными властями.

Когда Европейский центральный банк только создавался, основная идея состояла в том, чтобы в результате получить независимый и аполитичный институт, занимающийся исключительно функционированием единой валюты. Но в настоящее время ЕЦБ имеет дело не только с так называемыми техническими вопросами. В рамках многоуровневого европейского управления Банк превратился в стратегического игрока, многие решения которого по сути политические. Само собой разумеется, что центральные банки не являются мажоритарными демократическими институтами - такими, как парламенты. Так, и ЕЦБ - это

\footnotetext{
${ }^{188}$ Balls E, Howat J, Stansbury A. (2016) Central Bank independence revisited: after the financial crisis, what should a model central bank look like? // M-RCBG Associate working paper, no. 67, Harvard Kennedy School of Government. URL: https://www.hks.harvard.edu/sites/default/files/centers/mrcbg/files/67_central.bank.v.2.pdf.

${ }^{189}$ Khan A. (2017) Central Bank legal frameworks in the aftermath of the global financial crisis // IMF working paper, no. 101. URL: https://www.imf.org/en/Publications/WP/Issues/2017/05/01/Central-Bank-Legal-Frameworks-in-theAftermath-of-the-Global-Financial-Crisis-44858.
} 
технократическая бюрократия, или немажоритарный институт, который, ради достижения поставленных ему в рамках развития интеграции целей, был изначально наделён политической независимостью.

Компетенция в сфере монетарной политики была передана ЕЦБ в пределах и на основании условий соответствующего мандата, который чётко определил цели денежнокредитной политики ЕС и тем самым ограничил масштаб дискреционных действий Европейского центрального банка. Однако исходный акт делегирования Банку определённых полномочий по Маастрихтскому договору в 1990-е годы остался незавершённым, открытым, коль скоро ЭВС продолжает развиваться на наших глазах, представляя собой допускающий последующие изменения политический компромисс, о котором на текущий момент способны договориться европейские правящие круги. Поэтому экстраординарные и нетрадиционные меры денежно-кредитной политики ЕЦБ и выполнение им функций по банковскому контролю, будучи совершенно законными и/или эффективными, могут, тем не менее, вызывать обоснованные сомнения в плане своей легитимности с общественной точки зрения. 


\section{Глава 3}

\section{БАНКОВСКИЙ СОЮЗ}

Мировой финансовый кризис, начавшийся в 2008 г., серьёзно подорвал экономическое и финансовое положение стран Европейского союза и еврозоны. Особенно ослабло доверие к европейской банковской отрасли. Кризис выявил со всей наглядностью, что многие банки в Европе были склонны к проведению рискованных операций, имели недостаточную капитализацию, легкомысленно приобретали правительственные долги, играли на американском рынке субстандартного кредитования (нацеленного на ненадежных заёмщиков). За восполнением неизбежных при таком подходе потерь они обращались к национальным правительствам, которым с октября 2008 г. по октябрь 2011 г. пришлось собрать в качестве поддержки и гарантий для европейских банков 4,5 трлн. евро, причём речь, конечно, шла о средствах налогоплательщиков, а не владельцев самих банков.

Экономисты и регуляторы и ранее рассматривали банковский сектор как наименее благополучную часть европейской экономики, по крайней мере отчасти усматривая причины его проблем в характере правительственной поддержки национальных банков и в изъянах пруденциального надзора. Международная конкуренция между финансовыми центрами подталкивала коммерческие банки к тому, чтобы обосновываться в странах, где регулирование менее строгое, а национальные правительства старались сформировать для них более привлекательную нормативную среду.

До кризиса суверенных долгов, тем не менее, мобильность капитала в еврозоне была высокой, поскольку после введения евро оформление единого финансового рынка заметно продвинулось вперёд. Необходимо вспомнить, что, начиная с 1980-х годов, финансовая отрасль в ЕС прошла через непрекращающуюся волну дерегулирования. В рамках строительства ЕВР минимальная гармонизация была распространена на рынки кредитных институтов, страхования и ценных бумаг. Однако спустя десятилетие возник запрос на более централизованный подход, обещавший способствовать повышению конкурентоспособности Евросоюза в глобальном масштабе через оздоровление европейской финансовой отрасли. В противном случае свободное движение капитала в рамках ЕВР угрожало регуляторным арбитражем с концентрацией притока капитала в странах со слабым надзором и недобросовестным регулированием, повышающими системные риски для ЕС в целом ${ }^{190}$.

В конце 1990-х годов Программа действий в сфере финансовых услуг (Financial Services Action Programme), рассчитанная на шесть лет, нацелила европейские институты на принятие 42 директив по разным формам финансовых трансакций, чтобы, как тогда планировалось, создать в ЕС в подлинном смысле интегрированный финансовый рынок к 2005 г. ${ }^{191}$. Трансграничная экономическая активность порождала существенные проблемы координации между юрисдикциями, что повышало запрос на наднациональное регулирование.

Почти все директивы, предусмотренные в Программе, действительно удалось принять к концу 2004 г. Кроме того, примерно тогда же (в 2001 г.) был запущен процесс Ламфалюсси (названный так по имени Александра Ламфалюсси - Alexandre Lamfalussy, главы Комитета

190 De Bandt O. and Hartmann P. (2000) Systemic Risk: A Survey // ECB Working Paper, No. 35. URL: https://www.ecb.europa.eu/pub/pdf/scpwps/ecbwp035.pdf.

${ }^{191}$ Подробнее см.: Financial Services Action Plan. 18 дек. 2004 г. (updated: 23 дек. 2011 г.). URL: 18 дек. 2004 г. (updated: 23 дек. 2011 г. URL: https://www.euractiv.com/section/uk-europe/linksdossier/financial-services-action-plan. 
мудрецов по регулированию европейских рынков ценных бумаг - Committee of Wise Men on the Regulation of European Securities Markets, возглавлявшего работу над докладом, в котором этот процесс был предложен). Процесс Ламфалюсси изменил организационно-правовую структуру регулирования финансовых услуг в $\mathrm{EC}^{192}$. Соответствующий регуляторный подход был нацелен на более оперативную выработку необходимых европейской финансовой отрасли решений. Он включил четыре институциональных уровня:

(1) Европейский парламент и Совет принимали базовые правовые нормы по предложению Комиссии, ограничиваясь утверждением лишь общих базовых принципов и сосредоточившись на ключевых политических решениях (первый уровень);

(2) на основании базовых норм Комиссия сама принимала и обновляла технические имплементирующие меры (второй уровень);

(3) комитеты национальных надзирателей (в банковской области, по ценным бумагам и страхованию) консультировали Комиссию по вопросам принятия актов первого и второго уровня, но сами не могли принимать решений и обеспечивать их выполнение, ограничиваясь решением задач по сотрудничеству и координации действий национальных инстанций (третий уровень);

(4) Комиссия следила за тем, чтобы национальные правительства корректно проводили принятые европейские меры в жизнь (четвёртый уровень).

В 2011 г., под влиянием экономических потрясений, в свою очередь, была усовершенствована, как мы уже упоминали, схема финансового надзора в Евросоюзе, которая теперь стала сочетать меры национального контроля с решением особых задач на европейском уровне, поскольку выполнение соответствующих задач только на национальном уровне, как это делалось ранее, приводило к разнобою в применяемых практиках и порождало фрагментацию Единого внутреннего рынка. На этом этапе она включила:

(a) Европейский совет по оценке системных рисков - ЕССР (макропруденциальный надзор), в котором центральная роль была отведена ЕЦБ.

(б) Европейскую систему финансовых контролёров - для наблюдения за отдельными финансовыми институтами (микропруденциальный надзор) - сеть национальных инстанций по финансовому надзору, работающих в тандеме с европейскими агентствами, в которые были преобразованы прежние комитеты национальных надзирателей, задействованные в процессе Ламфалюсси. Три агентства (их создание было предложено ещё в докладе Ларозьера 2009 г. $\left.{ }^{193}\right)$ включили, соответственно:

Европейское банковское ведомство (European Banking Authority - EBA) в Лондоне (ныне, в связи с выходом из ЕС Великобритании, перебравшееся в Париж);

Европейское ведомство по страхованию и трудовым пенсиям (European Insurance and Occupational Pensions Authority - EIOPA) во Франкфурте-на-Майне;

Европейским ведомством по ценным бумагам и рынкам (European Securities and Markets Authority - ESMA) в Париже.

Они взяли на себя все функции прежних комитетов третьего уровня в процессе Ламфалюсси, добавив к ним новые компетенции. Их обязанности и полномочия в сумме заключались:

- в координации работы национальных контролирующих инстанций;

- в реагировании на случаи неправильного применения национальными органами соответствующих регламентов ЕС (ведь регламенты, как акты прямого действия, не требуют перенесения в национальное законодательство);

\footnotetext{
${ }^{192}$ ttps:/ec.europa.eu/info/business-economy-euro/banking-and-finance/financial-reforms-and-their-progress/regulatoryprocess-financial-services/regulatory-process-financial-services_en.

${ }^{193}$ De Larosière Report. (2009) The high-level group on financial supervision in the EU. Brussels, 25 February 2009. URL: http://ec.europa.eu/internal_market/finances/docs/de_larosiere_report_en.pdf.
} 
- в разрешении споров национальных контролирующих инстанций в случае разногласий по вопросам, касающимся международных финансовых институтов;

- в гармонизации национальных правил регулирования и внедрение общих европейских инструкций;

- в наложении временных запретов или ограничений на определенную финансовую активность на рынке, угрожающую его стабильности или цельности, в особенности если того требует чрезвычайная ситуация, о наступлении которой объявит Совет;

- в мониторинге активности рейтинговых агентств (возложенный на Банковское ведомство), в том числе поручение проведения необходимых исследований национальным инстанциям;

- в проведении стресс-тестов для европейских банков (такая миссия тоже была поручена Банковскому ведомству).

Эти три ведомства вырабатывают технические стандарты по регулированию и по имплементации решений, которые формально принимает Европейская комиссия, а также от них исходят меры мягкого права - в форме указаний и рекомендаций для компетентных национальных органов. Совет и Европарламент, действуя на основании предложения со стороны Комиссии, могут при необходимости наделять эти ведомства дополнительными полномочиями.

Впрочем, очень скоро подобных усовершенствований опять-таки оказалось недостаточно. В 2013 г. Кипр стал пятой страной зоны евро, которой понадобилась помощь ближайших партнеров и МВФ ввиду неспособности оплатить свои долги, вызванные в том числе затратными программами по спасению национальных банков. Неудивительно, что в Евросоюзе стали задумываться о том, как бы переложить часть возникших убытков на сами банки, их вкладчиков или клиентов в согласии с принципом «bail-in»-оздоровления проблемных банков за счёт средств самих банков, их инвесторов и вкладчиков, ограждая налогоплательщиков на будущее от перспективы вливания государственных финансов для спасения банков. Непосредственным толчком к усилиям по централизации соответствующих функций на европейском уровне послужили события 2012 года, когда на первый план вышел испанский долговой кризис (в июне 2012 г. было одобрено выделение Мадриду до 100 млрд. евро от других государств еврозоны для рекапитализации банков).

Для систематического противостояния возможным угрозам финансовой дестабилизации в Брюсселе в новых условиях и был задуман Банковский союз как элемент финансовой интеграции, которого ранее не доставало. В концептуальном плане он должен был стать частью стабильного и процветающего Экономического и валютного союза, видение которого было представлено в докладе 2012 г. тогдашнего председателя Европейского совета Хермана ван Ромпёя под названием «По направлению к единому экономическому и валютному союзу» ${ }^{194}$.

Создание Банковского союза было согласовано на саммите Европейского совета, который состоялся 28-29 июня 2012 г. Его строительство не закончено до сих пор, но, тем не менее, обещает в более долговременной перспективе привести к самым серьёзным экономическим и политическим трансформациям в интегрированной Европе. Этот шаг стал самой серьёзной вехой углубления европейской интеграции со времени вступления в силу Маастрихтского договора 1992 г., учредившего Европейский союз, и сопровождался передачей на европейский уровень существенной доли национального суверенитета.

Банковский союз включает четыре компонента, большая часть которых уже действует:

1. Общий свод правил по банковскому капиталу и ликвидности для всего Евросоюза (Single Rulebook), с помощью которого приводятся к общему стандарту регуляторные правила

\footnotetext{
194 Осокина Е.Б. (2017) Предпосылки и основные положения реформы правового регулирования банковской деятельности в ЕС // Право и управление. ХХІ век, № 1, с. 66-74.
} 
в финансовом секторе и задаются нормативные рамки для европейского Банковского союза. В июне 2009 г. Европейский совет единогласно рекомендовал принять единую инструкцию, распространяющуюся на все финансовые институты, действующие на Едином внутреннем рынке. Ранее европейское банковское законодательство основывалось на директивах, которые оставляли место для существенного расхождения в национальных правилах (первая директива «о координации законодательства, правил и административных положений, регулирующих порядок организации и деятельности кредитных организаций» была принята Советом министров Европейского экономического сообщества в 1977 г. ${ }^{195}$ ). Выступив в июле 2011 г. с законодательным предложением о достаточности капитала для банков, Европейская комиссия, со своей стороны, запустила процесс имплементации в Евросоюзе глобальных стандартов, которые были одобрены «Большой двадцаткой» на саммите в Сеуле в ноябре 2010 года (так называемый Базель III).

Законодательный пакет по требованиям к капиталу, включающий директиву и регламент (CRDIV/CRR package) ${ }^{196}$ призван был повысить способность банков еврозоны поглощать убытки и снизить вероятность использования средств налогоплательщиков в случае банковского краха. Пакет вступил в силу с 17 июля 2013 г., а завершение полной имплементации в ЕС требований Базеля III ожидалось к 1 января 2019 г. Он включил основные унифицированные правила допуска к банковской деятельности и её осуществления. Регламентом, который имеет прямое действие, регулируются положения, относящиеся к определению размера регулятивного капитала, к требованиям по капиталу, к его качеству и количеству. Директива, требующая перенесения в национальное законодательство, касается таких вопросов, в которых жёсткость предписания не столь велика, включая выдачу лицензий, пруденциальный надзор, корпоративное управление и санкции. Воспроизводя положения «Базель III», указанные акты имели и некоторые отличия от него, отражающие учет европейской специфики ${ }^{197}$. Если базельские соглашения по достаточности капитала распространяются только на банки с международной активностью, то в ЕС соответствующие положения должны были применяться ко всем банкам, а также к инвестиционным компаниям. Столь широкий охват европейские власти объявили необходимым для того, чтобы банки, чья деятельность разрешена в одном государстве ЕС, могли оказывать свои услуги на всем ЕВР без ограничений. 23 ноября 2016 г. Европейская комиссия выступила с очередным пакетом банковских реформ, включающим изменённые регламент (CRR2) и директиву $(C R D V)$ по требованиям к капиталу ( $C R D V$ package). Они вступят в силу не ранее 2019 г. и, согласно планам, должны будут применяться только спустя два года после вступления в силу ${ }^{198}$.

Ключевая роль в пополнении общего свода правил в целях имплементации $C R D / C R R$ package, директивы о санации и урегулировании несостоятельности банков (Bank Recovery and Resolution Directive - BRRD) $)^{199}$, а также директивы о схеме по гарантированию банковских

195 The Council Directive 77/780/EEC of 12 December 1977 on the coordination of the laws, regulations and administrative provisions relating to the taking up and pursuit of the business of credit institutions (no longer in force). URL: https://eur-lex.europa.eu/legal-content/EN/TXT/?uri=CELEX\%3A31977L0780.

${ }^{196}$ Включает регламент - Regulation (EU) No 575/2013 of the European Parliament and of the Council of 26 June 2013 on prudential requirements for credit institutions and investment firms and amending Regulation (EU) No 648/2012 (OJ L 321, 26.6.2013, p. 6) и директиву - Directive 2013/36/EU of the European Parliament and of the Council of 26 June 2013 on access to the activity of credit institutions and the prudential supervision of credit institutions and investment firms, amending Directive 2002/87/EC and repealing Directives 2006/48/EC and 2006/49/EC (OJ L 176, 27.6.2013, p. 338), подробнее см.: Худякова Л.С., Сидорова Е.А. (2014) Реформа регулирования финансового сектора в Европейском союзе // Деньги и кредит, № 4, с. 28-29.

${ }^{197}$ Худякова Л.С. (2013) Новые подходы к межгосударственному финансовому регулированию. - Тезисы доклада $\kappa$ заседанию Ученого совета ИМЭМО РАН 25 сентября 2013 г., с. 5-6. Доступ: http://old.imemo.ru/ru/sc/2013/25092013 prez.pdf.

$198 \mathrm{http} / / /$ europa.eu/rapid/press-release_IP-16-3731_en.htm.

${ }^{199}$ Directive 2014/59/EU of the European Parliament and of the Council of 15 May 2014 establishing a framework for the recovery and resolution of credit institutions and investment firms and amending Council Directive 82/891/EEC, and 
вкладов (Deposit Guarantee Scheme Directive - DGSD) ${ }^{200}$ отдана Европейскому банковскому ведомству (ЕБВ), созданному в 2011 г. Оно вырабатывает обязательные для исполнения всеми странами Евросоюза технические стандарты, которые ЕК выпускает в форме регламентов или решений, после чего они становятся частью национального законодательства государствчленов.

2. Единый механизм по банковскому надзору - EMH (Single Supervisory Mechanism - SSM) для еврозоны, который заработал в ноябре 2014 г. Задачи по банковскому надзору были, соответственно, возложены на Европейский центральный банк (а Европейское банковское ведомство закономерным образом лишилось на перспективу функции по координации действий национальных надзирателей над кредитными институтами). ЕЦБ в рамках ЕМН должен обеспечивать «последовательное и полное выполнение в зоне евро» общего свода правил для банков. Для того чтобы это можно было оформить в короткие сроки, прибегли к статье 127(6) Договора о функционировании Европейского союза, что давало возможность обойтись без внесения изменений в основополагающий Договор. В период, когда Евросоюз ещё не отошёл от перипетий процесса ратификации Лиссабонского договора 2007 г., у европейских элит не возникало желания повторять этот болезненный опыт. Попытка внесения договорных изменений сулила в принципе надолго задержать реализацию идеи Банковского союза.

Банковский надзор сложился в итоге как дифференцированный, при котором ЕЦБ должен работать в тесном сотрудничестве с национальными надзорными ведомствами. Непосредственный надзор осуществляют совместные команды по надзору (Joint Supervisory $T e a m s-J S T s)^{201}$, куда входят представители ЕЦБ и национальных надзорных органов. Прямой надзор со стороны ЕЦБ был распространён на банки (общим число около 130 - на их долю приходится свыше 80\% банковских активов в еврозоне), отвечающие следующим критериям:

(1) один из трёх крупнейших банков в стране по объёму активов;

(2) банк с активами свыше 30 млрд. евро;

(3) банк с активами, равными не менее чем 20\% от ежегодного ВВП страны происхождения, но не менее 5 млрд. евро;

(4) любой другой банк с высоким уровнем трансграничной активности.

Проекты решений по надзору готовит Совет по надзору, внутренний орган ЕЦБ, состоящий из глав банковского надзора всех стран БС плюс шесть представителей от ЕЦБ.

Эти решения, которые принимаются простым большинством голосов ${ }^{202}$, включают:

- определение микро- и макропруденциальных требований по достаточности капитала;

- определение статуса значимости банков, которые подлежат надзору;

- выдачу и отмену банковских лицензий;

- оценку приобретения и продажи банками квалифицированной доли участия;

- применение в отношении значимых банков мер принудительного характера и санкций.

Совет управляющих ЕЦБ служит окончательной инстанцией при принятии соответствующих решений, что делает их обязательными в юридическом смысле. При этом действует процедура «молчаливого согласия», на основании которой подразумевается, что СУ

Directives 2001/24/EC, 2002/47/EC, 2004/25/EC, 2005/56/EC, 2007/36/EC, 2011/35/EU, 2012/30/EU and 2013/36/EU, and Regulations (EU) No 1093/2010 and (EU) No 648/2012, of the European Parliament and of the Council. http://eurlex.europa.eu/legal-content/EN/TXT/PDF/?uri=CELEX:32014L0059\&from=EN. Данная реформа также охвачена пакетом банковских реформ, призванных повысить устойчивость банковского сектора Европы, которые был предложены в 2016 г. и находятся на рассмотрении европейской легислатуры.

${ }^{200}$ Directive 2014/49/EU of the European Parliament and of the Council of 16 April 2014 on deposit guarantee schemes. URL: http://eur-lex.europa.eu/legal-content/EN/TXT/?uri=CELEX:02014L0049-20140702.

${ }^{201}$ Подробнее см.: https://www.bankingsupervision.europa.eu/banking/approach/jst/html/index.en.html.

${ }^{202}$ Verhelst S. (2013) Assessing the Single Supervisory Mechanism: Passing the Point of No Return for Europe's Banking Union, Brussels: Egmont Institute, pp. 23, 32-33. 
по умолчанию поддерживает конкретное (техническое) решение Совета по надзору, если на протяжении относительно короткого периода времени (до 10 дней) он не выдвинул против него своих возражений ${ }^{203}$. Совет управляющих не может вносить в такие решения собственные поправки. Национальные регуляторы сохраняют за собой функции и полномочия, относящиеся, например, к регулированию защиты прав потребителей финансовых услуг и выполнения текущих надзорных функций.

3. Единый механизм по санации банков - ЕМСБ, который начал свою работу с 1 января 2016 г. В случае, когда под угрозой состоятельность банка системной значимости, ЕМСБ занимается его реструктуризацией или восстановлением. Единый совет по финансовому оздоровлению - ЕСФО (Single Resolution Board - SRB), куда, в том числе, вошли представители от каждого из участвующих государств-членов, принимает программу санации, которая вступает в силу в течение 24 часов, если только Комиссия или Совет министров ЕС по каким-то особым причинам не выдвигают против этого плана свои возражения. Если программа всё же осуществляется, частные инвесторы должны вложиться в санацию банка согласно принципу «bail-in» и взять на себя соответствующие расходы объёмом до 8\% банковских активов. По достижении указанного предела банк получает доступ к Единому фонду санации - ЕФС (Single Resolution Fund - SRF), откуда он может получить сумму, равную 5\% собственных активов. ЕФС - это совместный фонд объёмом в 55 млрд. евро, финансируемый из вкладов самих банков, а также инвестиционных фирм, в его национальные отделения. В течение восьми лет (2016-2023 гг.) национальные отделения должны быть постепенно сведены воедино. Если доступ к средствам ЕФС требуется банкам, не имеющим статуса системно значимых, то вопрос об этом самостоятельно решает ЕСФО. С Советом министров ЕС и национальными органами по санации банков консультируются в данном вопросе, но их возможности по вмешательству в процесс принятия решений очень ограничены.

4. Наконец, ещё одной опорой Банковского союза должна была стать Совместная (европейская) схема гарантирования банковских вкладов. Но в данном вопросе государствачлены пока не пошли далее простой гармонизации национальных схем, при которой «порочный круг», связывающий банки и суверенные государства, остаётся по сути не разорванным. Исходная директива о схемах по гарантированию вкладов была принята в ЕС в 1994 г., чтобы поддержать уверенность вкладчиков в банковской системе хотя бы минимальными средствами. По этой директиве, государства-члены обязаны были иметь национальную схему страхования вкладов, гарантирующую возврат не менее чем 90\% от суммы вклада, при общем лимите до 20 тыс. евро на человека. Под влиянием финансового кризиса 2008 г., эта директива дважды подвергалась пересмотру. Её вариант, принятый в марте 2009 г., требовал, чтобы государства-члены повысили соответствующий лимит до 100 тыс. евро. Очередное изменение было внесено в 2014 г. Оно, в частности, обеспечило более быстрый доступ для вкладчиков к их вкладам после банкротства банка.

Таким образом, в ЕС принят общий лимит полного возмещения банковских вкладов, который составляет 100 тыс. евро. Однако предложение о выработке единой для всего Евросоюза схемы гарантирования вкладов, которая должна была бы постепенно заместить существующие национальные схемы, продвигаемое Еврокомиссией с лета 2010 г. (формально законодательное предложение было выдвинуто ЕК в 2015 г. ${ }^{204}$ ), встретило упорное сопротивление в Берлине - причём вопреки мнению Международного валютного фонда и при поддержке данной идеи со стороны ЕЦБ. Предложение ЕК подразумевало, что на начальной

\footnotetext{
${ }^{203}$ Wymeersh E. (2015) Banking Union; Aspects of the Single Supervisory Mechanism and the Single Resolution Mechanism compared // ECGI Working Paper Series in Law, no. 290. URL: http://www.ecgi.global/sites/default/files/working_papers/documents/SSRN-id2599502.pdf.

204 Подробнее см.: https://ec.europa.eu/info/publications/commission-proposal-european-deposit-insurance-schemeedis_en.
} 
стадии правительства получат доступ к общим фондам в случае исчерпания своих собственных ресурсов (и до определённого уровня). Полный переход к совместному несению рисков должен был начаться не ранее 2024 г.

Подобный план некоторым образом затрагивает проблему создания в ЕС трансферного союза ${ }^{205}$. Его выполнение постоянно наталкивается на возражения Германии (её поддерживают в этом вопросе, в частности, Нидерланды), позиция которой обосновывается тем, что общее финансирование в ЕС системы гарантирования вкладов невозможно в отсутствие хотя бы зачатков наднационального фискального союза (при котором европейские институты получили бы большую власть в бюджетно-налоговой сфере).

Европейская комиссия по-прежнему стремится к тому, чтобы впредь вопрос о гарантировании банковских вкладов не зависел от юрисдикции каждой отдельной страны. Подобные планы активно поддерживают Франция и страны Южной Европы. Но в октябре 2017 г. Берлин в очередной раз воспротивился намерению официального Брюсселя возобновить переговоры о переходе к европейской централизованной схеме гарантирования вкладов (European Deposit Insurance Scheme - EDIS) ${ }^{206}$. Берлин отказывается участвовать в переговорах на эту тему до тех пор, пока в отношении европейских банков не достигнуто существенное снижение рисков - несмотря на то, что в своих очередных предложениях Комиссия постаралась учесть германскую озабоченность. Новые предложения ЕК предусматривают только временную поддержку ликвидностью национальных фондов по гарантированию вкладов, причём эти средства нужно будет вернуть. Таким образом, в данном случае речь не идёт о сведении рисков воедино.

При обсуждении европейского Банковского союза необходимо подробней остановиться на Европейском механизме стабильности ${ }^{207}$. Это постоянно действующий фонд финансовой стабилизации стран еврозоны со штаб-квартирой в Люксембурге. Он был учреждён в октябре 2012 г. на основании договора $a d$ hoc, заключённого вне договорной базы ЕС, заменив собой два временных фонда: Европейский фонд финансовой стабильности (European Financial Stability Facility - EFSF) и Европейский механизм финансовой стабилизации (European Financial Stabilisation Mechanism - EFSM).

Чтобы учредить ЕМС, потребовалось внести изменение в Договор о функционировании Европейского союза, для чего в статью 136 был добавлен пункт 3 следующего содержания: «Государства-члены, валютой которых является евро, могут создать стабилизационный механизм, который будет активирован в случае необходимости сохранения стабильности зоны евро в целом. Предоставление любой необходимой финансовой помощи в рамках данного механизма будет осуществляться при соблюдении жестких условий». Вопрос о праве государств-членов еврозоны на заключение и

\footnotetext{
205 Механизмы по спасению пострадавших от кризиса государств-членов в Европейском союзе зачастую рассматриваются наблюдателями как предвестие перехода к трансферному союзу между странами зоны евро. Но полный трансферный союз должен характеризоваться постоянными, прямыми и горизонтальными переводами денежных средств между странами. ЕС и зона евро далеки от соответствия критериям такого рода трансферного союза. URL: https://www.dbresearch.com/PROD/RPS_ENPROD/PROD0000000000461501/A_European_transfer_union\%3A_How_large\%2C_how_powerful.PDF.

206 Подробнее см.: https://ec.europa.eu/info/business-economy-euro/banking-and-finance/banking-union/europeandeposit-insurance-scheme_en.

207 Подробней о Европейском механизме стабильности см.: Топорнин Н.Б. (2015) Некоторые аспекты правового статуса и деятельности механизмов финансовой помощи в Европейском союзе // Деньги и кредит, №10, с. 5861. См. также European Parliament. European Stability Mechanism (ESM): Mail Features, Instruments and Accountability. In-depth analysis. February $2018 . \quad$ URL: http:/www.europarl.europa.eu/RegData/etudes/BRIE/2014/497755/IPOL-ECON_NT(2014)497755_EN.pdf.
} 
ратификацию соглашений, подобных Договору о $\mathrm{EMC}^{208}$, рассматривался в Суде ЕС в связи с делом «Томас Прингл против правительства Ирландии» 209.

Как следует из принятого судебного решения, изменение, внесённое в статью 136 ДФЕС, которое открыло путь к учреждению Европейского механизма стабильности, лишь прояснило status quo, не меняя ранее создавшуюся ситуацию. Оно подтвердило и ранее по факту существовавшее право государств-членов на вступление в подобный договор. Суд заключил также, что данный Договор не противоречит статье 125 ДФЕС, по которой ни Союз не отвечает по обязательствам государств-членов ЕС, ни сами государства не отвечают по обязательствам друг друга («no bailout» clause).

В период кризиса средства ЕМС были доступны тем странам зоны евро, которым грозил дефолт по суверенному долгу (соответствующую помощь получили Греция, Кипр и Испания, а с учётом работы его предшественника - Европейского фонда финансовой стабильности, учреждённого в 2010 г. - также Ирландии и Португалии $\left.{ }^{210}\right)$. Поддержка предоставлялась в обмен на согласие стран-получательниц выполнять рекомендуемые кредиторами (от лица которых выступали Европейская комиссия, Европейский центральный банк и Международный валютный фонд) меры жёсткой экономии. Протоколы о намерениях, которые этим странам пришлось подписать в качестве условия предоставлениям им помощи из ЕФФС и ЕМС, не только в совокупном виде определяли объёмы требуемых от них сокращений государственных расходов, но и то, как такие сокращения должны были распределяться, а также намечали определённые структурные реформы регулирования национальных рынков.

Так, протокол для Греции содержал обязательство её правительства пойти на всеобъемлющие реформы в области здравоохранения и рынка труда, а Португалия, помимо прочего, согласилась сократить госрасходы на пенсии. Деньги на финансовую помощь по этой линии должны были привлекаться на рынках под гарантии государств - членов ЕМС (как подтверждает таблица 3-4, при оплачиваемой им доле акционерного капитала в 80 млрд. евро ЕМС был способен предоставить странам на условиях займа до 705 млрд. евро, из которых на январь 2018 г. оставалось не использованными 75\%).

Министры финансов еврозоны, заседающие в составе Еврогруппы, составляют Совет управляющих ЕMC (он собирается не реже одного раза в год), который принимает важнейшие решения (в том числе подзаконные нормативные акты) единогласно. Представители Европейской комиссии и ЕЦБ могут участвовать в его заседаниях в качестве наблюдателей. Исполнительный органом ЕМС выступает Совет директоров во главе с Клаусом Реглингом (Klaus Regling), срок полномочий которого на посту исполняющего директора продлится до октября 2022 г. В сфере компетенции Совета директоров - одобрение предоставления кредита конкретной стране (такие решения принимаются квалифицированным большинством, составляющим $80 \%$ поданных голосов $)^{211}$.

\footnotetext{
208 Договор, учреждающий ЕМС, был подписан 12 февраля 2012 г. Ныне действует его консолидированная версия, принятая после вступления в EMC Латвии и Литвы, которая была принята в 2015 г. URL: https://www.esm.europa.eu/legal-documents/esm-treaty

${ }^{209}$ C-370/12, Thomas Pringle v Government of Ireland, November 27th, 2012. CM.: De Witte Bruno, Beukers Thomas (2013) The Court of Justice approves the creation of the European Stability Mechanism outside the EU legal order: Pringle // Common Market Law Review, Volume 50, Issue 3, pp. 805-848; Туркина А.В. (2016) Европейский стабилизационный механизм и правовая система Европейского союза // Успехи современной науки, том 3, № 9, c. 142-148. См. также: Kingston Suzanne (2013) Pringle judgment breaks new ground. URL: https://www.irishtimes.com/business/pringle-judgment-breaks-new-ground-1.1254042.

210 Общий объём кредитов, предоставленных пяти странам по линии ЕМС и ЕФФС, составил 273 млрд. евро.

211 Совет управляющих может делегировать Совету директоров выполнение определённых задач. Подробнее: Пашковская И.Г. (2016) Деятельность Европейского Союза по актуализации правовых основ Экономического и валютного союза после мирового финансового и экономического кризиса 2008 года // Мировая политика, № 2. URL: http://e-notabene.ru/wi/article_19140.html.
} 
Капитал Европейского механизма стабильности

\begin{tabular}{|c|c|}
\hline Подписной капитал & $€ 704.8 \mathrm{bn}$ \\
\hline Оплаченная доля акционерного капитала & $€ 80.5 \mathrm{bn}$ \\
\hline $\begin{array}{l}\text { Заявленная гарантированная часть } \\
\text { резервного капитала }\end{array}$ & € $624.3 \mathrm{bn}$ \\
\hline Максимальная кредитоспособность & $€ 704.8 \mathrm{bn}$ \\
\hline $\begin{array}{l}\text { Сохраняющаяся кредитоспособность } \\
\text { (январь } 2018 \text { г.): } 75 \%\end{array}$ & $€ 378$ bn \\
\hline
\end{tabular}

Источник: https://www.esm.europa.eu/

Главной целью ЕМС было определено предоставление кредитов государствам-членам. Но его средства могут также быть использованы для поддержки пострадавших финансовых институтов. Так, инструмент непрямой капитализации (indirect capitalisation) используется в $\mathrm{EMC}$, если корни кризиса заключены в финансовом секторе и не имеют прямого отношения к бюджетной или структурной политике правительства страны, которая от кризиса пострадала. В 2012 г. данный инструмент уже использовали для предоставления помощи Испании. В этом случае кредит предоставляется опять-таки национальному правительству, которое оказывает помощь пострадавшим банкам из средств национального бюджета.

Кроме того, в декабре 2014 г. в арсенале ЕМС появился инструмент прямой рекапитализации (direct recapitalization instrument), который может быть использован в особых условиях, чтобы напрямую (т.е. минуя национальные правительственные инстанции) рекапитализировать финансовые институты в качестве крайнего средства уже после того, как были применены все другие инструменты, в том числе механизм «bail-in», внедрённый в банковскую систему ЕС на основании директивы о санации и урегулировании несостоятельности банков, а также задействован Единый фонд санации. Получить соответствующие средства могут только кредитные институты системной значимости, находящиеся под надзором ЕЦБ.

Теперь экономическая ситуация в Европе стабилизировалась, наблюдается небольшой экономический рост. Удалось вернуть доверие международных инвесторов. Греция, последняя из пяти стран, которые получали финансовую помощь по линии ЕМС, завершила свою программу международной поддержки летом 2018 г. В данной связи в правящих кругах Европейского союза стали задумываться о будущей роли ЕМС.

В частности, Европейская комиссия в декабре 2017 г., основываясь на статье 352 ДФЕС, закрепившей подразумеваемую компетенцию Союза, предложила трансформировать ЕМС в Европейский валютный фонд (European Monetary Fund $\left.{ }^{212}\right)^{213}$ (принятие данного предложения Советом зависит от согласия Европейского парламента). В его рамках, согласно предложениям ЕК, был бы обеспечен тыловой заслон (backstop) в форме предоставления кредитной линии или гарантий для ЕФС, что позволило бы последнему действовать в качестве кредитора последней инстанции, чтобы облегчить упорядоченные антикризисные меры в отношении пострадавших банков, подкрепив таким образом надёжность действий Единого совета по финансовому оздоровлению. Создание подобного заслона уже было в принципе согласовано государствами-членами Европейского союза, но пока не заработало. Помимо

\footnotetext{
${ }^{212} \mathrm{https}$ //ec.europa.eu/commission/sites/beta-political/files/european-monetary-fund_en.pdf.

${ }^{213} \mathrm{https} / / /$ ru.delfi.lt/news/economy/evrokomissiya-hochet-sozdat-evropejskij-valyutnyj-fond.d?id=76567509.
} 
этого, по словам Клауса Реглинга, ЕМС следует подготовиться к наращиванию собственной роли в программах помощи ввиду того, что Международный валютный фонд в будущем может сократить или прекратить своё участие в них ${ }^{214}$.

Поскольку Европейский механизм стабильности был создан вне договорной основы функционирования ЕС, на него не распространяются положения, касающиеся контроля над деятельностью европейских институтов, органов и агентств. В частности, он не подотчётен Европейскому парламенту. Министры финансов, составляющие его Совет управляющих, отвечают перед своими национальными парламентами - но каждый по отдельности. ЕП, со своей стороны, предпринял усилия, чтобы укрепить формы парламентского рассмотрения программ финансовой помощи. Соответствующие задачи были возложены на парламентский комитет по экономическим и валютным вопросам. Ему в помощь в 2016 г. была создана парламентская рабочая группа по финансовой помощи (Financial Assistance Working Group $F A W G)^{215}$. Доклад Пяти председателей 2015 г., посвященный завершению строительства ЭВС к 2025 г., содержал предложение об интеграции ЕМС в правовые рамки Европейского союза к 2015 г. $^{216}$. Предложение Европейской комиссии об учреждении Европейского валютного фонда, в свою очередь, предусматривает для Европейского парламента консультативную роль в процессе назначения его исполнительного директора, а также определённые формы отчётности ЕВФ Совету министров, Комиссии, ЕП (ежегодные доклады, слушания, устные и письменные вопросы), а также национальным парламентам.

Единый финансовый рынок и Банковский союз нужны для успешно функционирующего валютного союза. Но интегрированные банковские рынки, национальный банковский надзор и финансовая стабильность не могут быть обеспечены на должном уровне одновременно и составляют «невозможную троицу» ${ }^{217}$. Выйти из этой ситуации можно двумя путями: либо вернуться в мир сегментированных, национальных банковских рынков и забыть о преимуществах их региональной интеграции, либо перейти к наднациональным структурам финансового надзора и санации. Фрагментация финансового сектора стала бы ключевым препятствием для успешного функционирования общей кредитно-денежной политики в еврозоне, а также помешала бы инвестициям и экономическому росту в регионе. Но делегирование новых полномочий европейским институтам остаётся болезненной темой для государств-членов. Когда они идут на это, то стараются сохранить свою вовлечённость в процесс принятия решений.

Передача надзорных полномочий наднациональному институту (ЕЦБ) позволила преодолеть провалы, имевшие место ранее в координации на европейском уровне надзорной политики отдельных стран, и лишила национальных регуляторов возможности проявлять снисходительность в отношении своих, недостаточно капитализированных, банков. Она гарантировала, что принципы, которые были согласованы на глобальном уровне или внутри EC, будут последовательно применяться в рамках еврозоны без учёта национальных границ. Применение во всех странах еврозоны общих стандартов в области банковского надзора позволяет с большей надежностью идентифицировать слабые банки.

Вместе с тем финансовый надзор - это сложная и кропотливая работа. Хотя у сотрудников ЕЦБ уже накопился некоторый опыт её выполнения на микропруденциальном

214 «The role of the ESM in a deepening EMU» - speech by Klaus Regling. 02.02.2018. URL: https://www.esm.europa.eu/speeches-and-presentations/role-esm-deepening-emu-speech-klaus-regling.

$215 \mathrm{http} / /$ greece.greekreporter.com/2016/01/22/european-parliament-approved-to-monitor-implementation-of-greek-aidprogram/

${ }^{216}$ Completing Europe's Economic and Monetary Union. Report by Jean-Claude Juncker in close cooperation with jeroen Dijsselbloem, Mario Draghi and Martin Schulz. P. 21. https://ec.europa.eu/commission/sites/beta-political/files/5presidents-report_en.pdf.

${ }^{217}$ Schoenmaker D. (2013) An Integrated Financial Framework for the Banking Union: Don’t Forget Macro-Prudential Supervision $/ / \quad$ EC Economic Papers, no. 495, April. http://ec.europa.eu/economy_finance/publications/economic_paper/2013/pdf/ecp495_en.pdf. 
уровне, ограниченность его кадрового состава и нехватка квалификации у его сотрудников в новой для ЕЦБ области могут подрывать его способность самостоятельно выполнять задачи по банковскому надзору.

Единый механизм по санации банков вступает в действие, когда в частном секторе не удаётся найти решения для рекапитализации слабого банка. Главная цель ЕСФО состоит в том, чтобы обеспечить реорганизацию проблемных банков, сведя к минимуму связанные с нею затраты налогоплательщиков. Единый механизм предусматривает стандартизированные рамки такой деятельности с чёткими, прозрачными правилами, которые должны применяться в случае необходимости финансового оздоровления неустойчивых кредитных институтов. В директиве о санации и урегулировании несостоятельности банков, действие которой распространяется на все государства-члены ЕС, был прописан «каскад обязательств» (liability cascade), в согласии с которым деньги налогоплательщиков могут быть использованы для спасения терпящего бедствие банка лишь после (хотя бы частичного) «bail-in»- вовлечения держателей облигаций/вкладчиков в процесс его финансового оздоровления, а также использования средств Единого фонда санации. Предусмотренные данной директивой «bailin» процедуры применяются с 1 января 2016 г. В сущности, связь между государствами и банками в таком случае разрывает и то, что проблемами санации занимаются не национальные правительства непосредственно, а европейские инстанции.

Вместе с тем Единый механизм санации банков страдает от недостатка политического доверия к нему. Банки в ЕС остаются в существенной мере национальными, что более явно выражено в крупных странах (Франция, Германия, Испания и Италия, а также Нидерланды). В небольших государствах-членах присутствует больше иностранных банков, что особенно заметно в странах Центральной Европы. Поэтому не следует удивляться, что некоторые крупные страны дольше сопротивлялись перенесению ответственности за санацию банков на уровень ЕС.

Прежде всего, звучат серьёзные сомнения, что операции по спасению от банкротства с привлечением национальных правительств («bail-outs») действительно будут использоваться только как исключительная мера и лишь в самом крайнем случае. Складывающаяся практика соответствующие сомнения не рассеивает. Так, в 2017 г. при определении судьбы испанского банка Banco Popular было решено, что он будет продан без государственной помощи, т.е. в строгом соответствии с европейскими правилами, но после того, как ЕЦБ запустил механизм ликвидации двух небольших итальянских банков (Veneto Banca и Banca Popolare di Vicenza) итальянское правительство выделило до 17 млрд. евро на их спасение (получив соответствующее разрешение от Европейской комиссии), чтобы сохранить рабочие места в регионе Венето, сбережения итальянских домохозяйств, являющихся клиентами названных банков, и защитить финансовые интересы сотен тысяч местных компаний. Эти два банка являются крупнейшими в регионе, и их коллапс нанёс бы жестокий экономический урон окрестным сообществам.

Если банковские стейкхолдеры будут по-прежнему надеяться, ориентируясь на практику, подобную итальянской, что вмешательство национального правительства хотя бы отчасти оградит их от угрозы несения убытков при финансовом крахе, то у них и в будущем сохранятся побудительные стимулы к более рискованному поведению. Вопросы вызывает и запутанное распределение обязанностей между европейскими и национальными властями в рамках Единого механизма санации, которое может мешать эффективному и оперативному решению возникающих проблем.

Наконец, стандартизация национальных схем по гарантированию банковских депозитов вместо введения общей системы страхования вкладов - это недостаточная мера для того, чтобы снизить зависимость в ситуации с банковской ликвидностью в той или иной стране от легко просчитываемых бюджетных возможностей отдельных государств. Нежелание благополучных в экономическом отношении государств идти на коллективизацию 
(обобществление) финансовых рисков ведёт к тому, что ответственность за страхование банковских вкладов по-прежнему лежит на национальном уровне власти. В результате вероятность панического изъятия вкладов остаётся в зависимости от положения дел с суверенным долгом в той или иной стране.

Просматриваемые перспективы Банковского союза не сулят преодоления отмеченных проблем в ближайшее время. Ослабление усилий по реформированию регулирования банковской отрасли, которое наблюдается на глобальном уровне, тоже работает против успешного «капитального ремонта» банковского сектора в Европе. К тому же не все европейские игроки проявляют повышенный интерес к дальнейшему укреплению финансового регулирования и надзора. В частности, возникают конфликты между Единым механизмом по санации банков и национальными властными органами, которые могут опасаться, что слишком жёсткий европейский подход к надзору помешает «своим» банкам в стране заниматься кредитованием и расти.

Наконец, немаловажно, что Банковский союз в Евросоюзе охватывает только кредитные институты еврозоны, то есть остаётся неполным. Страны Европейского союза, которые остаются за пределами еврозоны, имеют возможность присоединиться к Банковскому союзу, но, по сложившимся правилам, не обязаны это делать. Если в странах, остающихся вне Банковского союза, кредитные институты будут нести меньшую регуляторную нагрузку, нежели банки еврозоны, то обоснованными можно считать неизбывные опасения по поводу возможности подрыва финансовой стабильности на Едином внутреннем рынке.

\section{Дифференциация}

Европейский банковский союз формируется внутри Единого внутреннего рынка, но непосредственно охватывает только часть государств-членов ЕС (в настоящее время - 19 стран, которые перешли на единую валюту евро). Таким образом, речь в данном случае идёт об очередном примере дифференцированной интеграции, что в принципе подразумевает различия в условиях подключения отдельных государств-членов к Экономическому и валютному союзу (а также к Пространству свободы, безопасности и правосудия, которое в настоящей работе не рассматривается).

Наличие возможности дифференциации позволяет большинству стран ЕС продвигаться в развитии интеграции вперёд, не принуждая к этому всех без исключения ${ }^{218}$. Для определения различных видов и форм «гибкой интеграции», помимо собственно термина дифференцированная интеграция (differentiated integration), могут также использоваться такие наименования, как изменяемая геометрия (variable geometry), Eвропа разных скоростей (multi-speed Europe) или Eвропа a la carte ${ }^{219}$.

Дифференциация, подразумевающая неоднородность политического пространства интеграции, стала для ЕС необходимостью, прежде всего, ввиду большого числа государствучастников и широких компетенций самого Союза. Как замечает в данной связи российский специалист Л.О. Бабынина, у отдельных государств-членов несовпадающие интересы и разный объём ресурсов. Отсутствует также общее понимание целей и задач интеграции, что в совокупности и приводит к многообразию форм «гибкой интеграции» 220 . К этому можно добавить неравномерную способность наднациональных институтов оказывать влияние в

\footnotetext{
${ }^{218}$ См. Борко Ю.А. (2007) Свет и тени европейской интеграции // Россия в глобальной политике, №1. URL: http://www.globalaffairs.ru/number/n_8140.

219 Подробнее см.: Кавешников Н.Ю. (2011) Гибкая интеграция» в Европейском союзе // Международные процессы, том 9, № 2 (26), с. 58-69.

${ }^{220}$ Бабынина Л.О. (2014) Трансформация внутренней архитектуры ЕС: проблемы фрагментации политического пространства // Политическая наука. М., ИНИОН, № 2, с. 44-64.
} 
различных областях европейской политики, а также особое политическое значение, которое придаётся некоторым вопросам экономики и внутренней безопасности на фоне других.

Множество форм, в которых на практике находит воплощение дифференциация, можно группировать в соответствии с временными, территориальными либо отраслевыми критериями $^{221}$, которые, однако, взаимно не исключают друг друга. В этой связи европейский Банковский союз являет собой пример функциональной, отраслевой дифференцированной интеграции, которая имеет также территориальные и временные параметры (для начала включает страны еврозоны, но имеет и потенциал для распространения на другие государствачлены).

Переход на евро с формальной точки зрения для большинства государств-членов Европейского союза (за исключением Великобритании и Дании, пользующихся оговоркой о «не участии» (opt-out clause), позволившей им не переходить на наднациональную валюту сколь угодно долго) является императивом - в том случае, когда обеспечено соответствие критериям конвергенции. Последнее касается Болгарии, Хорватии, Чехии, Швеции, Венгрии, Польши и Румынии. В отличие от этого, членство в Банковском союзе для стран ЕС за пределами зоны евро непосредственно обязательным не является. Все они без исключения могут, тем не менее, изъявить своё желание добровольно участвовать в ЕМН, вступив в соглашение с ЕЦБ (если ЕЦБ примет на этот счёт положительное решение) ${ }^{222}$ и не переходя при этом на евро, из чего последует, однако, их автоматическое присоединение и к Единому механизму санации 223 . Отношения тесного сотрудничества с ЕЦБ впоследствии могут быть прекращены (спустя не менее 3 лет после их начала) по инициативе страны, в них вступившей, либо по решению самого ЕЦБ.

Создавшаяся в отношении Банковского союза пёстрая картина (детали см. в табл. 3-1) даёт повод для рассуждений о том, как подобная дифференциация сказывается на перспективах валютной интеграции ${ }^{224}$. В конце концов, она способна подталкивать страны, остающиеся пока вне зоны евро, к переходу на единую валюту, поскольку иначе для крупных трансграничных европейских банков, при наличии у них таковых, возникает обременительная проблема вынужденной игры по разным национальным правилам одновременно.

Но означает ли всё это, что единые регуляторные рамки в финансовой области в сочетании с единой системой финансового надзора должны непременно охватывать всё пространство ЕВР? Опыт Соединённых Штатов Америки, к примеру, показывает, что это не всегда так. В США сложилась некоторая степень конкуренции между финансовыми регуляторами и органами финансового надзора. Отдельные американские штаты сохраняют собственные регулирующие и надзорные органы - в дополнение к федеральным агентствам и федеральному законодательству. Поскольку систему с идеальными параметрами выстроить непросто, некоторый элемент конкуренции между действующими правилами в пределах пространства региональной интеграции может даже быть полезен, благотворен, позволяя

\footnotetext{
${ }^{221}$ Stubb A. (1996) A Categorization of Differentiated Integration // Journal of Common Market Studies, vol. 34, issue 2, p. 283.

${ }^{222}$ Council Regulation (EU) No 1024/2013 of 15 October 2013 conferring specific tasks on the European Central Bank concerning policies relating to the prudential supervision of credit institutions SSM Regulation, Art. 7 OJ L 287, 29.10.2013, p. 63; Decision of the European Central Bank of 31 January 2014 on the close cooperation with the national competent authorities of participating Member States whose currency is not the euro (ECB/2014/5). URL: https://www.ecb.europa.eu/pub/pdf/other/en_dec_2014_05 fen.pdf.

${ }^{223}$ SRM Regulation, Art 4. Regulation (EU) No 806/2014 of the European Parliament and of the Council of 15 July 2014 establishing uniform rules and a uniform procedure for the resolution of credit institutions and certain investment firms in the framework of a Single Resolution Mechanism and a Single Resolution Fund and amending Regulation (EU) No 1093/2010. URL: https://eur-lex.europa.eu/legal-content/EN/TXT/?uri=celex\%3A32014R0806.

224 Подробнее см.: Leuffen D., Rittberger B. and Frank Schimmelfennig F. (2013) Differentiated Integration:
} Explaining Variation in the European Union, London: Palgrave Macmillan. 
дополнительно протестировать, какие именно правила находят наилучшими для себя непосредственные участники рынка.

Тем не менее, главная претензия, которую можно высказывать по поводу приравнивания границ действия полномочия в рамках Единого надзорного механизма к границам зоны евро, сводится к тому, что в принципе оно не имеет непосредственного отношения к практике банковского надзора или к характеристикам поддержания финансовой стабильности в Европе. Конкретное институциональное решение было избрано, исходя из того, что только оно и могло быть реализовано в опоре на статью 127(6) ДФЕС, тогда как внедрение полномасштабной системы в пределах ЕВР потребовало бы внесения изменений в основополагающий Договор, с чем не соглашались некоторые страны, начиная с Великобритании. Но ожидать, пока Великобритания окончательно выйдет из ЕС, тоже вряд ли было бы оптимальным решением.

Таблица 3-1

Экономическая интеграция стран ЕС, остающихся вне зоны евро: формальное состояние дел

\begin{tabular}{|c|c|c|c|c|}
\hline Страна & ЭВС & Фискальный пакт & $\begin{array}{l}\text { Европейский } \\
\text { механизм } \\
\text { стабильности } \\
\end{array}$ & Банковский союз \\
\hline Болгария & $\begin{array}{c}\text { не перешла на } \\
\text { евро, но стремится } \\
\text { к этому }\end{array}$ & участвует & не участвует & $\begin{array}{c}\text { проявляет } \\
\text { заинтересованность } \\
\text { в участии }\end{array}$ \\
\hline Великобритания & $\begin{array}{c}\text { не перешла на евро } \\
\text { и не стремится к } \\
\text { этому (opt-out) } \\
\end{array}$ & не участвует & не участвует & $\begin{array}{c}\text { не проявляет } \\
\text { заинтересованности } \\
\text { в участии } \\
\end{array}$ \\
\hline Венгрия & $\begin{array}{c}\text { не перешла на евро } \\
\text { и не стремится к } \\
\text { этому }\end{array}$ & участвует частично & не участвует & $\begin{array}{c}\text { не проявляет } \\
\text { заинтересованности } \\
\text { в участии } \\
\end{array}$ \\
\hline Дания & $\begin{array}{c}\text { не перешла на евро } \\
\text { и не стремится к } \\
\text { этому (opt-out) }\end{array}$ & участвует & не участвует & $\begin{array}{c}\text { проявляет } \\
\text { некоторую } \\
\text { заинтересованность } \\
\text { в участии } \\
\end{array}$ \\
\hline Польша & $\begin{array}{c}\text { не перешла на евро } \\
\text { и не стремится к } \\
\text { этому }\end{array}$ & участвует частично & не участвует & $\begin{array}{c}\text { не проявляет } \\
\text { заинтересованности } \\
\text { в участии } \\
\end{array}$ \\
\hline Румыния & $\begin{array}{c}\text { не перешла на } \\
\text { евро, но стремится } \\
\text { к этому } \\
\end{array}$ & участвует & не участвует & $\begin{array}{c}\text { заинтересована в } \\
\text { участии }\end{array}$ \\
\hline Хорватия & $\begin{array}{c}\text { не перешла на } \\
\text { евро, но стремится } \\
\text { к этому }\end{array}$ & не участвует & не участвует & $\begin{array}{c}\text { не проявляет } \\
\text { заинтересованности } \\
\text { в участии (до } \\
\text { перехода на евро) } \\
\end{array}$ \\
\hline Чехия & $\begin{array}{c}\text { не перешла на евро } \\
\text { и не стремится к } \\
\text { этому }\end{array}$ & не участвует & не участвует & $\begin{array}{c}\text { проявляет } \\
\text { заинтересованность } \\
\text { в участии } \\
\end{array}$ \\
\hline Швеция & $\begin{array}{c}\text { не перешла на евро } \\
\text { и не стремится к } \\
\text { этому } \\
\end{array}$ & участвует частично & не участвует & $\begin{array}{c}\text { не проявляет } \\
\text { заинтересованности } \\
\text { в участии } \\
\end{array}$ \\
\hline
\end{tabular}

Источник: составлено автором

Помимо прочего, в рамках ЕМН Европейский центральный банк несёт ответственность только в отношении коммерческих банков, но не за весь финансовый сектор (в этом плане возможности, которые открывала статья 127(6), тоже оказались ограниченными), т.е. она 
асимметричная и не распространяется, например, на страховые компании, финансовые учреждения, не выполняющие депозитные функции, и на теневой банкинг.

В целом картина дифференциации, сложившаяся в отношении Банковского союза, выглядит следующим образом. Определённые правила являются частью единого рынка ЕС в области финансовых услуг. Их действие распространяется на все государства - члены Евросоюза без исключения. Речь идёт о нормах, зафиксированных в директиве по требованиям к капиталу $(C R D)$ и в регламенте по требованиям к капиталу $(C R R)$, в директиве о санации и урегулировании несостоятельности банков $(B R R D)$ и в директиве о схеме по гарантированию банковских вкладов $(D G S D)$. При этом, строго говоря, важнейшая директива $B R R D$ не является непосредственной частью Банковского союза. В странах, остающихся вне БС, зафиксированные в ней правила должны, тем не менее, имплементироваться национальными инстанциями.

Институты, составляющие опору управления на этом рынке, включают Европейское банковское ведомство и Европейский совет по оценке системных рисков, которые входят в Европейскую систему финансового надзора. Финансовое законодательство, именуемое Общим сводом правил по банковскому капиталу и ликвидности, включающее правовые нормы ЕС (регламенты и директивы) и технические стандарты, применяется во всех 28 государствах - членах ЕС в целях гармонизации и дальнейшего продвижения ЕВР ради обеспечения равных условий для деятельности финансовых институтов.

Только в отношении членов Банковского союза, в свою очередь, действуют регламент о Едином механизме по банковскому надзору, регламент о Едином механизме по санации банков, а также межправительственное соглашение о переводе взносов в Единый фонд санации проблемных банков еврозоны 225 (его подписали 26 государств-членов, за исключением Швеции и Великобритании). Институтами, ответственными за этот участок работы, являются ЕЦБ и национальные органы по надзору (в рамках Единого механизма по надзору), а также Единый совет по финансовому оздоровлению и соответствующие компетентные национальные органы в рамках Единого механизма по санации банков.

К этому следует добавить, что большая часть упомянутых выше правовых норм по единому рынку, которые касаются сферы финансовых услуг и распространяются на всех членов ЕС, вошла в соглашение о Европейском экономическом пространстве. Оно предусматривает свободное движение товаров, капитала, услуг и людей (четыре свободы) в рамках Европейского единого рынка и включает три из четырёх стран - членов Европейской ассоциации свободной торговли (Норвегию, Исландию и Лихтенштейн). Регламенты ЕС, касающиеся европейских надзорных ведомств, включая Европейское банковское ведомство, $B R R D$, пакет $C R I V$ и DGSD ещё предстоит туда инкорпорировать.

Наконец, в отношении Швейцарии, которая не вошла в Европейское экономическое пространство, будучи членом ЕАСТ, действуют некоторые двусторонние соглашения (в том числе соглашение в области финансовых услуг, затрагивающее вопросы страхования, не связанного с рисками для жизни).

Страны Евросоюза, которые остаются вне еврозоны, представляют собой крайне неоднородную группу. Их финансовые системы находятся на разных уровнях развития и в разной степени конвергенции с зоной евро. Но финансовые и экономические сопряжения между собой стран ЕС, находящихся в зоне евро и остающихся вне зоны евро, тем не менее, очень сильны, и их легкомысленно было бы игнорировать.

Правительство Великобритании, важнейшего игрока на финансовых рынках в Европе, с самого начала отказалось от участия в создании Европейского банковского союза, проявив

\footnotetext{
${ }^{225}$ Intergovernmental Agreement (IGA) on the Transfer and Mutualization of Contributions to the Single Resolution Fund. URL:

https://www.ris.bka.gv.at/Dokumente/RegV/REGV_COO_2026_100_2_1105493/COO_2026_100_2_1106424.pdf 
особую непреклонность в отстаивании национального суверенитета в данном вопросе. Выступая в Берлине в июне 2012 г., тогдашний британский премьер-министр Дэвид Камерон заявил: «Поскольку мы не перешли на единую валюту, мы не станем принимать участия в углублённых элементах данного банковского союза» ${ }^{226}$. При этом Лондон пока выполняет Общий свод правил по банковскому капиталу и подчиняется $B R R D$, как и ещё четырём десяткам регламентов и директив по регулированию финансовых услуг.

Лондон в принципе мог бы оставаться финансовой столицей Европы и после Брексита. Чтобы сохранить доступ для лондонского Сити к рынку ЕС на будущее, Великобритания хотела бы обеспечить «взаимное признание» британского и европейского режимов в сферах финансового регулирования и надзора, но Брюссель занял жёсткую позицию по вопросу финансовых услуг, настаивая, что Лондону после выхода из ЕВР придётся полагаться на принцип эквивалентности (признание правил торгового партнёра, если считается, что они ведут к такому же по сути результату), который является стандартным условием для рыночного доступа на единый рынок ЕС для стран, которые не входят в Евросоюз 227.

Поскольку в Великобритании после Брексита ожидается (сравнительно с ЕС) более низкий экономический рост, в Брюсселе имеют также хождение опасения, что это может стать стимулом для Лондона, чтобы пойти на ослабление регулирования в национальной банковской сфере, в отношении которой власти ЕС утратят прежнюю (и до сих пор относительную) меру влияния. Тем самым будет подрываться легитимность (жизнеспособность) еврозоны, и определённое развитие событий может привести к новому финансовому кризису. При всём том, учитывая глубокую взаимозависимость ЕС и Великобритании, обе стороны будут заинтересованы в нахождении некоей формы продолжающегося сотрудничества, чтобы упорядочить нормы регулирования и обеспечить финансовую стабильность в дальнейшем.

Серия банковских слияний и поглощений в 1990-х и 2000-х годах привела в тому, что две банковские группы, базирующиеся в Швеции, - Swedbank u SEB - стали доминирующими во всём регионе Северной Балтии, рассматривая его как свой расширенный «внутренний» рынок. Тем не менее правительство Швеции пока отказывается от участия в БС, несмотря на внушительное трансграничное присутствие шведских банков в Эстонии, Латвии и Литве, которые входят в еврозону и, следовательно, полностью участвуют в Банковском союзе. Стокгольм руководствуется при этом несколькими соображениями. Во-первых, в Швеции недовольны, что страны-члены вне еврозоны в случае присоединения к БС в любом случае не получат полных прав участия в принятии решений. Во-вторых, шведские правящие круги заботит неопределённость, окружающая вопрос будущей финансовой ответственности в БС: Стокгольм не хочет платить за рекапитализацию или санацию чужих банков, оказавшихся в бедственном положении. Между тем распределительные последствия ЕМС весьма чувствительны для Швеции ввиду её структурного положения как страны происхождения крупных интернационализированных банков.

В-третьих, Швеция предпочитает сохранять национальную автономию в сфере банковского регулирования, особенно в кризисных ситуациях - при возникновении угрозы стабильности национальной банковской системы ${ }^{228}$. Европейская комиссия нацелена на максимальную возможную гармонизацию при внедрении общего свода правил при имплементации CRDIV package, тогда как Швеция предпочитает подход с позиций большей гибкости и национальной свободы рук. В то же время отметим, что системно значимые

\footnotetext{
226 URL: https://www.telegraph.co.uk/news/politics/david-cameron/9317418/David-Cameron-We-wont-take-part-inEU-banking-union-its-not-our-currency.html.

${ }^{227} \mathrm{https}: / /$ www.ft.com/content/52515664-1278-11e8-940e-08320fc2a277.

${ }^{228}$ Spendzharova Aneta B. \& Bayram Ismail Emre (2016) Banking union through the back door? How European banking union affects Sweden and the Baltic States // West European Politics, vol.39, no 3, pp. 565-584. URL: https://www.tandfonline.com/doi/pdf/10.1080/01402382.2016.1143245.
} 
подразделения шведских банков в трёх прибалтийских республиках подлежат надзору в рамках Единого механизма по надзору и при нынешнем состоянии дел.

Выражая озабоченность тем, что ЕЦБ, в Совете управляющих которого страны, не входящие в зону евро, не будут представлены даже в случае вхождения в Банковский союз, может обрести доминирующую позицию в области определения технических правил банковского надзора для всего ЕС (Совет по надзору в рамках ЕМН подчинён СУ) ${ }^{229}$, такие страны, как Великобритания, Швеция и Дания, искали противовес данной нежелательной для них тенденции в определении модуса голосования в Европейском банковском ведомстве, что позволило бы им всё же сохранить некоторый вес в принятии соответствующих решений. В декабре 2012 г. в отношении голосования в ЕБВ по настоянию указанных стран (прежде всего Великобритании) был введён принцип двойного большинства, которым обеспечивалось, что для исходящих от ЕБВ решений требуется их поддержка, как минимум, простым большинством стран, которые членами еврозоны не являются ${ }^{230}$.

В марте 2018 г. Nordea - один из крупнейших банков Скандинавии принял окончательное решение переместить собственную штаб-квартиру из Стокгольма в Хельсинки, т.е. в Финляндию, которая является членом еврозоны, объяснив такой шаг желанием иметь дело с «предсказуемыми налогами и тарифами, соответствующими тем, что платят банки в других странах» ${ }^{231}$, и предпочтительностью для него регуляторных рамок Банковского союза $^{232}$. Как следует из комментариев наблюдателей, к нему подтолкнуло введение шведским правительством в стране обязательной стабилизационной пошлины, призванной позволить накопить достаточный запас средств для того, чтобы национальным образом предохранить Швецию от финансового кризиса в будущем. Подобное перемещение естественным путём повышает давление на Швецию, заставляя её переосмыслить своё решение о неучастии в БС.

В Дании национальные политические партии активно высказывались против того, чтобы облегчать создание институциональных условий, при которых стране, в экстренном случае, пришлось бы платить за провалы банков в других государствах-членах ${ }^{233}$. Здесь следует отметить, что фактор евроскептицизма, значимый на национальной политической сцене, в принципе играет особенно важную роль в сдерживании шагов по углублению интеграции Дании в Евросоюз, хотя датская политическая элита в целом стоит на проевропейских позициях. Влияние фактора евроскептицизма следует также признать существенным в Великобритании и Швеции. Поддержка Экономического и валютного союза с единой наднациональной валютой в этих странах осенью 2017 г., согласно данным Евробарометра, находилась на уровне в 25\% (Швеция), 30\% (Великобритания) и 31\% (Дания) - при средней цифре по всему Евросоюзу в $61 \%{ }^{234}$.

Глава Банка Дании Ларс Роде высказывался в пользу присоединения страны к БС. Он, в частности, заявил в июле 2017 г.: «Укрепление надзора над европейскими банками и совместные органы санации относятся к числу наиболее важных мер после финансового кризиса, если речь идёт об обеспечении финансовой стабильности» ${ }^{235}$. Датское правительство выражало интерес к установлению более тесного сотрудничества с ЕЦБ по данному направлению. Брексит и возросшее в его результате внимание к Дании как к внутреннему

\footnotetext{
${ }^{229}$ Hennessy A. (2014) Redesigning financial supervision in the European Union (2009-2013) // Journal of European Public Policy, volume 21, issue 2, p. 163.

${ }^{230}$ Barker A. Britain threatens to block banking union //Financial Times, November 8, 2012.

${ }^{231} \mathrm{http}: / /$ www.rosbalt.ru/business/2018/03/16/1689286.html.

${ }^{232} \mathrm{http}$ ///bruegel.org/2017/nordeas-move-to-the-banking-union-is-no-surprise/.

${ }^{233}$ Nielsen, J.H. (2015) In or out? Denmark during the Euro Crisis // Same, Same but Different: The Nordic EU Members during the Crisis, Stockholm: Swedish Institute for European Policy Studies (SIEPS), p. 16.

234 Standard $\quad$ Eurobarometer $\quad 88, \quad$ Autumn $2017 . \quad$ http://www.pocicompete2020.pt/admin/images/Standard_Eurobarometer_88_UE_dez-2017.pdf. P. 37.

$235 \mathrm{https} / /$ www.reuters.com/article/us-denmark-eu-banking-cenbank/danish-central-bank-welcomes-review-of-possibleeu-banking-union-membership-idUSKBN19P1DX.
} 
финансовому центру ЕC повышают заинтересованность датского правительства в присоединении к БС (но не к еврозоне). Окончательное решение по данному вопросу, как ожидается, должно быть принято к осени 2019 г.

Венгрия, Чехия, Хорватия и Польша, где на национальных рынках преобладают банки еврозоны, пока продолжают занимать выжидательную позицию. При этом чешское правительство составило доклад, оценивающий преимущества и риски, которые могут быть связаны с вовлечением страны, с её сильным банковским сектором, в более тесное сотрудничество с ЕЦБ. Это можно расценить как свидетельство некоторого повышения интереса к перспективе присоединения к БС со стороны властей и экспертов Чехии (их осторожную поддержку данной идеи). Однако ввиду стабильности чешских банков острой необходимости в скором принятии соответствующего решения не ощущается - до тех пор, пока созданные на европейском уровне институциональные рамки не подтвердят своей полезности. Массовая поддержка ЭВС и евро при этом составляет в стране всего 22\%. Это самый низкий показатель по $\mathrm{EC}^{236}$, хотя объективно Чехия близка к выполнению всех необходимых критериев конвергенции. Иными словами, большинство чехов не хотят перехода своей страны на единую валюту. Налицо существенное изменение общественного мнения по сравнению к первой половиной 2000-х годов, когда большинство в стране высказывалось в пользу такого перехода, что можно объяснить потрясениями, пережитыми с тех пор еврозоной.

По заявлению главы Национального банка Хорватии (массовая поддержка ЭВС и евро в этой стране составляет $43 \%{ }^{237}$ ) Бориса Вуйчича, сделанному в мае 2016 г., «присоединение к Банковскому союзу представляет собой единственную целесообразную опцию для любого государства-члена, которое планирует вводить евро. Но до этого нам следует защищать наши особые интересы в создавшихся условиях» ${ }^{238}$. Согласно его дальнейшим пояснениям, сейчас наилучшей позицией для Хорватии является ожидание, пока будут укомплектованы все три ключевые опоры: совместный надзор (Единый механизм по надзору), совместный фонд срочной помощи и совместная гарантия по вкладам. Только когда всё это удастся завершить, вступление в Банковский союз станет вполне отвечать национальным интересам Хорватии. Поскольку организационная структура БС не достроена, а его механизмы недостаточно испытаны, для подобной осторожности есть все основания. Так как общие фонды для кризисного менеджмента в рамках Банковского союза пока не доступны, убытки, вызванные банковским кризисом, всё равно придётся покрывать, скорее всего, национальным налогоплательщикам, тогда как скорость принятия экстренно необходимых решений в случае присоединения к Банковскому союзу сразу замедлится ${ }^{239}$.

В Польше и Венгрии (национальная поддержка ЭВС и евро в этих странах составляет, соответственно, $36 \%$ и $57 \%{ }^{240}$ ), в свою очередь, более акцентировано стремление правительств подчинить банковскую политику именно продвижению национальных интересов. Они стараются расширить для себя пространство манёвра относительно влияния наднациональных институтов в собственном банковском секторе ${ }^{241}$ и подчёркивают важность поддержания финансовой независимости между «родительскими» банками за рубежом и их отделениями и дочерними структурами в стране.

\footnotetext{
${ }^{236}$ Standard Eurobarometer 88. P.37.

${ }^{237}$ Ibidem.

${ }^{238} \mathrm{https}: / /$ www.hnb.hr/en/-/bankovna-unija-ostvarenja-i-izazovi.

${ }^{239}$ Подробнее см.: Yoji Koyama (2016) Chapter 8: Croatia's Challenges Regarding the Adoption of the Euro // The Eurozone Enlargement // Ed. by: Yoji Koyama - Nova Science Publishers.

${ }^{240}$ Standard Eurobarometer 88. P.37.

${ }^{241}$ Méró Katalin \& Piroska Dora (2016) Banking Union and banking nationalism - Explaining opt-out choices of Hungary, Poland and the Czech Republic // Policy and Society, vol. 35, no 3.
} 
Польская банковская система, в которой на долю кредитных институтов еврозоны приходится немногим менее 50\% банковских активов (16 банков), считается довольно защищённой. В кризисное время там не случилось банкротств и поэтому не приходилось оказывать помощь несостоятельным банкам. По мнению польских экспертов, таким благополучием страна во многом обязана консервативным традициями национального банковского надзора, которые препятствуют смягчению правил кредитной политики для банков $^{242}$. Как следует из доклада Национального банка Польши, «оставаясь вне ЕСФО, Польша сможет предпринимать свои собственные независимые действия по санации местных кредитных институтов в соответствии с директивой о санации банков $B R R D »{ }^{243}$. Руководство страны выступает за идею открытого банковского союза (для всего ЕС), в котором у стран еврозоны не было бы асимметричных преимуществ.

Аналогичным образом, по мнению Центрального банка Венгрии, её выжидательную позицию в отношении присоединения к Банковскому союзу оправдывают, в числе прочего, такие обстоятельства, как неопределённость по вопросу оформления общей системы гарантирования вкладов, непрозрачность внутренней организации ЕМН и нехватка информации по поводу мер практической подготовки ЕЦБ к более тесному сотрудничеству со странами ЕС вне зоны евро ${ }^{244}$. По прогнозам экспертов, в вопросе об установлении более тесных отношений с ЕЦБ Венгрия будет следовать за польскими решениями, чтобы не ставить под угрозу конкурентоспособность собственного банковского сектора ${ }^{245}$. Эти две страны не проявляют повышенного энтузиазма по поводу присоединения к единой валюте и в целом с опаской относятся к перспективам углубления наднациональной интеграции в Европейском союзе.

Румыния стала первой среди стран ЕС, не входящих в еврозону, которая в 2014 г. заявила о намерении присоединиться к Банковскому союзу, проявляя в этом вопросе заметный энтузиазм, но конкретную дату, когда бы это могло произойти, пока невозможно предсказать. В национальной банковской системы Румынии банки стран еврозоны явно доминируют. На их долю приходится до 80\% всех банковских активов в стране. Глава Национального банка Румынии Мугур Исэреску в данной связи подчёркивал: «Было бы целесообразно, чтобы эффективные трансграничные надзорные и регулятивные институты соответствовали реальности существенного, даже системного, трансграничного присутствия в банковских системах стран, остающихся вне еврозоны» ${ }^{246}$.

На самом деле Румыния ищет компенсацию низкой способности национального государства поддерживать финансовую стабильность в делегировании функции банковского надзора на наднациональный уровень, как и возможность приблизиться таким способом к основному течению европейской интеграции. Помимо нарастания объёма некачественных кредитов, с которыми стране трудно справляться самостоятельно, повышению привлекательности БС в Румынии может способствовать традиционно достаточно высокий уровень политической поддержки европейской интеграции населением страны, хотя он и претерпел снижение в кризисные годы. По данным стандартного опроса Евробарометра за осень 2017 г., 51\% румын склонны доверять ЕС. Румыния планировала перейти на евро в

\footnotetext{
${ }^{242}$ Profant Tomas, Toporowski Patryk (2014) Potential for Cooperation: Polish and Czech Standpoints on the Banking Union // PISM Policy Paper, № 16 (99), pp. 1-6. URL: https://www.pism.pl/files/?id_plik=18005.

${ }^{243}$ NBP (2015) The Economic Challenges of Poland's Integration with the Euro Area, Warsaw (translation - III.2015, Polish version - XI.2014), p. 95. URL: https://www.nbp.pl/en/publikacje/inne/The-economic-challenges-of-Poland-sintegration-with-the-euro-area.pdf.

${ }^{244}$ P. 64. Szombati A. (2017). Banking Union Through Hungarian Eyes - Assessment of a Possible Close Cooperation //Journal of Governance and Regulation, vol. 6, no 1, p. 64. URL: http://dx.doi.org/10.22495/jgr_v6_i1_p6.

${ }^{245}$ Kisgergely K., Szombat A. (2014) Banking Union through Hungarian Eyes - the MNB's Assessment of a Possible Close Cooperation //MNB Occasional Papers, 115, Budapest.

$246 \quad$ URL: http://ec2-54-72-50-240.eu-west-1.compute.amazonaws.com/World/Central-EasternEurope/Romania/Romania-s-CBG-eager-to-join-European-banking-union?ct=true.
} 
2019 г., но впоследствии отказалась от этих планов ввиду неспособности быстро добиться соответствия Маастрихтским критериям (критериям конвергенции) $)^{247}$.

В 2014 г. желание присоединиться к Единому механизму по надзору выразила и Болгария, оказавшаяся в состоянии жесточайшего банковского кризиса. Два главных болгарских банка пострадали от массового закрытия счетов, что сыграло свою роль в падении правительства Пламена Орешарски (Plamen Oresharski). Стресс-тесты, проведенные спустя два года, показали, что болгарская финансовая система в целом стабилизировалась. Но реализация планов Софии относительно БС застопорилась. В 2018 г. Болгария, теперь стремящаяся к скорейшему переходу на евро, дала понять, что она более не имеет намерения торопиться с присоединением к БС ранее того, как произойдёт её переход на наднациональную валюту. Планы по превращению Болгарии в 20-го члена еврозоны получили поддержку в Германии и Франции. При этом ЕЦБ считает состояние болгарского банковского сектора её главной слабостью и возможным препятствием для быстрого дальнейшего продвижения страны по интеграционному пути.

Таким образом, в целом нельзя исключать, что интеграционные процессы в рамках проекта Европейского банковского союза ещё будут набирать темп. В конечном счёте, наднациональная система надзора более беспристрастна и способна больше внимания уделять межстрановым эффектам (о потенциальных различиях в статусе стран зоны евро и стран вне зоны евро в качестве членов банковского союза можно получить общее представление на основании таблицы 3-2, которая приведена далее).

Таблица 3-2

Статус стран зонь евро и стран вне зоны евро в качестве членов Банковского союза

\begin{tabular}{|c|c|c|}
\hline Статус & Страны зоны евро & Страны вне зоны евро \\
\hline $\begin{array}{c}\text { Обязательность для страны } \\
\text { членства в Банковском } \\
\text { союзе }\end{array}$ & Да & Нет \\
\hline Участие в Совете по надзору & Да & Да \\
\hline $\begin{array}{c}\text { Участие в Совете } \\
\text { управляющих ЕЦБ }\end{array}$ & Да & Нет \\
\hline $\begin{array}{c}\text { Участие в Едином совете по } \\
\text { финансовому оздоровлению }\end{array}$ & Да & Да \\
\hline $\begin{array}{c}\text { Участие в Европейском } \\
\text { банковском ведомстве }\end{array}$ & Да & Да \\
\hline $\begin{array}{c}\text { Доступ к получению } \\
\text { ликвидности от ЕЦБ для } \\
\text { банков }\end{array}$ & Да \\
\hline $\begin{array}{c}\text { Доступ к Единому фонду } \\
\text { санации }\end{array}$ & Да & Да \\
\hline Доступ к средствам ЕМС & Да & Нет \\
\hline
\end{tabular}

Источник: составлено автором

«Собственные» банки государств - членов ЕС, остающихся вне банковского союза, могут оказаться в невыгодном положении относительно своих конкурентов. Решение о

247 Romania abandons euro adoption date of 2019, May 16 ${ }^{\text {th }} 2016$ URL: http://www.eiu.com/industry/article/1794233763/romania-abandons-euro-adoption-date-of-2019/2016-0_7. 
присоединении во многом зависит от сравнения привлекательности Банковского союза и меры устойчивости национальной системы поддержки для проблемных банков. Но пока преимущества БС выглядят лишь потенциальными и довольно неопределёнными, тогда как связываемые с ним издержки уже лучше поддаются оценке. Ввиду договорных ограничений страны, не перешедшие на евро, участвуя в Банковском союзе, в любом случае не получат в нём равного статуса со странами еврозоны. В то же время в краткосрочной перспективе преодолеть слабости недостроенного Банковского союза вряд ли удастся.

С технической точки зрения произошедшее ныне наделение ЕЦБ функциями банковского надзора, вероятно, выглядит естественным. Но с политической точки зрения такая институциональная перемена имеет важные небезобидные последствия, ведя к дальнейшему сосредоточению власти в наднациональном немажоритарном институте, который и без того уже достаточно силён. Речь идёт о надзоре в отрасли, сохраняющей, как подтвердила настоящая глава, исключительно тесную связь с национальными правительствами. 


\section{Глава 4}

\section{ОБЩАЯ ЭКОНОМИЧЕСКАЯ ПОЛИТИКА. ФИСКАЛЬНЫЙ СОЮЗ}

В Европе валютный союз (переход на наднациональную валюту) обрел реальность значительно раньше, нежели широкий экономический союз. По сию пору системная проблема еврозоны многим справедливо видится в рассогласовании между его денежно-кредитной политикой, которая была оформлена как жёстко наднациональная, и политикой налоговобюджетной, которая формально остаётся в сфере ответственности национальных правительств. Государства-члены, имея единую валюту, в экономическом отношении продолжают сильно разниться между собой, тогда как механизмы макроэкономической координации на европейском уровне, которые позволяли бы им справляться с такими различиями, хотя и развиваются, но остаются недостаточно надёжными и действенными.

Напомним, что к координации на европейском уровне национальной экономической политики призывал государства-члены Римский договор 1957 г., учредивший Европейское экономическое сообщество. С целью внедрения координационных механизмов в ЕЭС уже на ранней стадии его развития появились специальные комитеты (к примеру, Комитет по среднесрочной экономической политике) и тестировались особые процедуры ${ }^{248}$. Но успех на данном поприще долго оставался незаметным. Это, к примеру, наглядно проявилось в рассогласованной реакции экономик стран ЕЭС на кризис нефтяных цен в середине 1970-х годов

Сочетание национальной бюджетной политики и единой денежно-кредитной политики впоследствии продемонстрировало свою уязвимость при возникновении экономических шоков, в особенности асимметричных. Понятно, что при асимметричных шоках общая кредитно-денежная политика в еврозоне тем более не может в одинаковой степени подходить для всех государств-членов, если их экономики остаются неоднородными. Если экономика какой-то страны испытывает перегрев, в то время как в экономике другой страны наблюдается замедление темпов роста, трудно найти такое решение в денежно-кредитной области, которое было бы в равной мере пригодно для обоих случаев.

Однако в годы, когда строился ЭВС, в Европе была достаточно широко распространена уверенность (впоследствии обнаружившая свою неоправданность), что в его рамках, вследствие бурного развития рыночной интеграции, асимметричные шоки будут достаточно редким явлением ${ }^{249}$. Именно на такой уверенности и строились прогнозы относительно жизнеспособности построенного ЭВС, несбалансированность которого ни для кого не была секретом.

Вопреки оптимистичным ожиданиям, асимметричный шок особенно глубоко поразил еврозону, начиная с 2010 г. Долговой кризис резко затормозил экономический рост в некоторых странах, тогда как другие оказались затронуты этой проблемой лишь косвенно и, по большому счёту, незначительно. Так, в период с 2011 по 2013 гг. экономика в ключевых странах еврозоны топталась на месте, тогда как на периферии она продемонстрировала падение почти на 6\%. Существенно разошлись национальные показатели по уровню безработицы, причём такие различия, несмотря на некоторое падение безработицы в целом,

\footnotetext{
248 Подробнее по этому вопросу см.: European Communities Monetary Committee (1976). Compendium of Community Monetary Texts. Supplement to 1974 edition. Brussels and Luxembourg: ECSC - EEC - EAEC, pp. $42-45$. ${ }^{249}$ Allard C., Brooks P.K., Bluedorn J.C., Bornhorst F., Christopherson, K. Ohnsorge F. and Poghosyan T. (2013) Toward a Fiscal Union for the Euro Area // IMF Staff Discussion Note, no. 13/09, Washington, D.C.
} 
сохраняются до сих пор. Так, по состоянию на июль 2018 г. безработица в Германии составила $3,4 \%$, во Франции - 9,2\%, в Испании - 15,1\%, а в Греции - 19,5\%.

\section{Координация национальных курсов бюджетной и экономической политики}

«Доклад Делора» ${ }^{250}$ в 1989 г. отразил некоторое беспокойство европейской правящей элиты по поводу слабости экономического компонента планировавшегося ЭВС. В этом документе содержался призыв к введению достаточных институциональных мер предосторожности, которые прямо побуждали бы государства-члены, вошедшие в валютный союз, к соблюдению бюджетной дисциплины. Там говорилось, что пренебрежение национальных правительств бюджетной дисциплиной может негативно отразиться на стабильности будущей единой валюты.

Небезосновательные, как потом оказалось, опасения ряда авторитетных экспертов, что высокие и растущие суверенные долги когда-нибудь подорвут способность ЕЦБ обеспечивать ценовую стабильность (т.е. выполнять свою ключевую задачу), оставили след во всех важных документах и политических решениях, которые были приняты на пути к непосредственному оформлению ЭВС и сразу после того, как оно произошло. В так называемом Докладе Сапира 2004 г. отмечалось: «Неудовлетворительные показатели развития экономики в ЕС дают основание судить о том, что у Союза и его государств-членов отсутствуют механизмы, которые позволяли бы систематически уделять внимание многим сферам, вызывающим озабоченность. Это может быть отчасти связано с тем, как именно власти ЕС подходят к экономическому управлению» ${ }^{251}$. Фактическим молчаливым признанием европейской элитой несовершенства заложенных в Маастрихте в 1990-е годы рамок европейского экономического управления позже стала его реформа, начатая в 2010 г.

В качестве основных европейских институтов, причастных к координации курсов бюджетной политики национального уровня, в настоящее время выступают:

- Европейская комиссия (прежде всего Генеральный директорат по экономическим и финансовым вопросам);

- ЭКОФИН - Совет министров экономики и финансов ЕС;

- Экономический и финансовый комитет, куда входят национальные должностные лица высокого уровня. Он обеспечивает диалог между ЭКОФИН и национальными властями, готовит доклады на основании программ по бюджетной политике (программы стабилизации/конвергенции), которые предоставляют государства-члены. На базе его докладов ЭКОФИН может вырабатывать свои мнения и новые решения;

- Комитет по экономической политике, консультирующий ЭКОФИН, Генеральный директорат по экономическим и финансовым вопросам и Европейский совет;

- Еврогруппа - формализованные встречи Совета министров экономики и финансов ЕС более узкого круга (только для стран, перешедших на евро). Создание Еврогруппы в 1997 г. отразило франко-германский компромисс в отношении необходимости координации национальных курсов экономической политики в условиях перехода к валютному союзу. Франция настаивала (и продолжает настаивать по сию пору), что для управления ЭВС с единой валютой необходимо экономическое правительство как некий аналог экономического

\footnotetext{
${ }^{250}$ Итоговый документ рабочей группы по выработке правил функционирования ЭВС во главе с тогдашним председателем Еврокомиссии Жаком Делором. Committee for the Study of Economic and Monetary Union. Jacques Delors, Chairman. Report on economic and monetary union in the European community. Presented April 17, 1989. URL: http://aei.pitt.edu/1007/1/monetary_delors.pdf.

${ }^{251}$ Sapir André, Aghion Philippe, Bertola Giuseppe, Hellwig Martin, Pisani-Ferry Jean, Rosati Dariusz, Viñals José, Wallace Helen, Buti Marco, Nava Mario, Smith Peter M. (2004) An Agenda for a Growing Europe: The Sapir Report. Oxford: Oxford University Press, p. 92.
} 
блока в национальном правительстве. Им удалось сойтись на том, что в качестве своеобразного суррогата экономического правительства будут выступать встречи министров экономики и финансов стран еврозоны.

Сначала участники Еврогруппы осуществляли только обмен информацией. Но к настоящему времени именно Еврогруппа, а не ЭКОФИН в полном составе, стала играть лидирующую роль в мониторинге соблюдения членами еврозоны Пакта стабильности и роста - ПСР (Stability and Growth Pact - SGP). Она задействована также в реализации стратегии «Европа-2020. На основании Лиссабонского договора (статья 139.2 ДФЕС) этот орган обрёл власть принимать самостоятельные решения (в тех аспектах Интегрированных направлений экономической политик, которые затрагивают еврозону в целом). Европейская комиссия в декабре 2017 г. ${ }^{252}$ высказалась за то, чтобы в будущем у еврозоны всё же появился свой министр экономики и финансов в статусе заместителя председателя Комиссии и главы Еврогруппы. Его сфера ответственности включала бы следующее:

- обеспечение общих интересов экономики Европейского союза/еврозоны и их представительство на глобальном уровне;

- укрепление политики координации и надзор за соблюдением экономических, бюджетных и финансовых правил;

• артикуляцию бюджетной политики в еврозоне (касательно национальных бюджетов), соразмерной денежно-кредитной политике ЕЦБ;

- осуществление контроля над использованием бюджетных инструментов самих ЕС/еврозоны, в том числе в целях поддержки структурных реформ, макроэкономической стабилизации (в еврозоне) и конвергенции (вне еврозоны);

- надзор за работой Европейского валютного фонда (после его создания).

Наконец, в 2015 г. на основании решения Европейской комиссии был создан Европейский фискальный совет (European Fiscal Board) ${ }^{253}$. Это независимый экспертный консультативный орган в составе пяти человек (обладающих высокой научной квалификацией). Его члены назначаются Комиссией по предложению её председателя. Главой ЕФС является датчанин Нильс Tигесен (Niels Thygesen). Создание ЕФС было предусмотрено в рамках предложений по строительству фискального союза в Докладе пяти председателей 2015 года.

Европейский фискальный совет консультирует Европейскую комиссию по вопросам имплементации бюджетных правил Европейского союза в государствах-членах (в сферу его рассмотрения не входит европейский бюджет). По сути его роль состоит в том, чтобы по возможности мешать политизации соответствующих решений Комиссии. В ноябре 2017 г. Совет опубликовал свой первый доклад ${ }^{254}$. В докладе была поддержана, в частности, идея оформления отдельного бюджета для еврозоны, высказанная президентом Франции Э. Макроном. Она была охарактеризована как наиболее многообещающий способ обеспечить выполнение стабилизационной функции в рамках экономической политики EC на среднесрочную перспективу. В то же время ЕФС отметил, что ПСР до сих пор не избавлен от недостатков, оставляющих место для его усовершенствования. В частности, предусмотренный

\footnotetext{
${ }^{252}$ European Commission. Communication from the Commission to the European parliament, the European Council, The Council and the European Central Bank. A European Minister of Economy and Finance. Brussels, 6.12.2017 COM (2017) 823 final http://eur-lex.europa.eu/legal-content/EN/TXT/PDF/?uri=CELEX:52017DC0823\&from=EN.

${ }^{253}$ Commission Decision 2015/1937 (European Commission, 2015), amended through Commission Decision 2016/221 with respect to Head of Secretariat (European Commission, 2016a) European Commission (2015). Commission Decision (EU) 2015/1937 of 21 October 2015 establishing an independent advisory European Fiscal Board. Official Journal of the European Union L 282/37. European Commission (2016a). Commission Decision (EU) 2016/221 of 12 February 2016 amending Decision (EU) 2015/1937 establishing an independent advisory European Fiscal Board. Official Journal of the European Union L 40/15.

${ }^{254}$ URL: https://ec.europa.eu/info/files/2017-european-fiscal-board-annual-report_en.
} 
в нём санкционный режим построен таким образом, что применение европейских санкций в отношении стран - нарушительниц Пакта на практике продолжает выглядеть маловероятным.

В своё время Маастрихтским договором 1992 г. (статья 104, ныне статья 126 ДФЕС) были предусмотрены две процедуры по обеспечению экономической конвергенции в еврозоне после обеспечения (в 1998 г.) необратимой фиксации обменных курсов валют стран-участниц. Во-первых, это процедура многостороннего наблюдения (multilateral surveillance procedure). Данная процедура подразумевала требование, чтобы страны зоны евро впредь проводили экономическую политику с учётом общеевропейских интересов, но сама по себе не предполагала жёстких наказаний в случае их отклонения от общего курса. Во-вторых, это процедура чрезмерного дефицита (excessive deficit procedure), при которой, при неисполнении рекомендаций по ликвидации бюджетных дефицитов, на государство ЕС могли быть наложены санкции.

Таким образом, речь шла о мониторинге национальной бюджетной политики и, при необходимости, штрафовании расточительности отдельных стран. Задачу мониторинга бюджетных процессов и накопления государствами-членами суверенного долга Маастрихтский договор возложил на Еврокомиссию. Пакт стабильности и роста оформил соответствующие требования в более жёсткую систему предупреждений, рекомендаций и, наконец, штрафов. Непосредственные параметры Пакта были установлены в 1997 г. регламентами Совета министров ЕС. Затем его положения были включены в Амстердамский договор 1997 г. (ПСР вступил в силу с 1 января 1999 г.) ${ }^{255}$.

Основные критерии, на которые с 1990-х годов ориентировались государства ЕС в проведении бюджетной политики, включили ежегодный дефицит госбюджета не выше $3 \%$ от величины национального ВВП и госдолг не более $60 \%$ от ВВП. Страны зоны евро обязаны были ежегодно представлять на рассмотрение на наднациональный уровень программы стабилизации с изложением мер, которые они намереваются предпринять, чтобы соответствовать критериям ПСР. Комиссия оценивала эти программы, а Совет министров (в данном случае ЭКОФИН) выносил по ним окончательное суждение квалифицированным большинством голосов, приняв в расчёт оправдания провинившегося правительства и мнение Экономического и финансового комитета (голоса той страны, у которой обнаружился чрезмерный дефицит, при этом не учитывались). скромные:

Далее могли воспоследовать следующие превентивные действия, сначала довольно

- раннее предупреждение со стороны Комиссии о том, чтобы правительство озаботилось предотвращением возникновения чрезмерного дефицита;

- европейская рекомендация национальным властям о мерах, позволяющих исправить ситуацию.

Если превентивных усилий оказывалось недостаточно и государство всё же нарушало требования ПСР, Комиссия могла дать непосредственный старт процедуре чрезмерного дефицита, предусматривавшей, в крайнем случае, санкции в отношении «проштрафившегося» правительства. Но эта процедура, впрочем, так ни разу и не была доведена до конца. Главная претензия, которая предъявлялась к ПСР в его начальной форме, состояла в том, что он сосредоточивался практически исключительно на единственном критерии (дефицит национального бюджета), что не помешало нескольким государствам-членам выйти далеко за рамки разрешенного госдолга в $60 \%$ от ВВП.

\footnotetext{
${ }^{255}$ Resolution of the European Council on the SGP; Council Regulation on the strengthening of the surveillance and coordination of economic policies, No. 1466/97; Council Regulation on speeding up and clarifying the implementation of the excessive deficit procedure, No. 1467/97; (Official Journal L 209, 02/08/1997), and the Council Regulation 1466/97 as amended by Council Regulation 1055/2005 and Council Regulation 1467/97 as amended by Council Regulation 1056/2005 (Official Journal L 174, 07/07/2005).
} 
ПСР знавал тяжёлые времена. Впервые он встретился с трудностями в 2002-2003 гг., когда его правила нарушили, в числе прочих, ведущие страны Евросоюза - Германия и Франция ${ }^{256}$ (в германском случае это было связано с тяжелым бременем расходов на национальное объединение). Вместо того чтобы применить Пакт, обеспечив бюджетную дисциплину, по политическим соображениям было принято решение, что к «правилу о 3 процентах» возможен гибкий и более снисходительный подход. Этот эпизод продемонстрировал со всей ясностью, что жёсткая координация не сработала, и породил множество предложений об укреплении Пакта. Главная проблема состояла в том, что угроза наложения санкций оказалась неубедительной. Иначе говоря, исходную версию Пакта явно подрывала сомнительная возможность его исполнения.

В 2005 г. под предлогом учёта конкретных экономических обстоятельств и специфических национальных особенностей была предпринята реформа ПСР, вследствие чего контроль над соблюдением бюджетных правил не только не укрепился, а был на деле существенно смягчён, тогда как временные рамки применения процедуры по исправлению бюджетных дефицитов - расширены. По сути же ничего существенного так и не было сделано из-за отсутствия согласия в рядах профессиональных экономистов и безволия политиков.

С новым и более серьезным вызовом Пакт столкнулся в результате мирового финансового кризиса в конце 2000-х годов, который выявил нетерпимое состояние государственных финансов в некоторых государствах-членах еврозоны и одновременно слабости рамок европейского управления в рассматриваемой сфере. Оно сосредоточивалось преимущественно на бюджетных дефицитах (но не на государственном долге), не предполагало действенной системы надзора и отличалось слабостью в части принуждения стран к выполнению европейских правил.

В отношении Греции кризисная ситуация усугубилась сознательным сокрытием Афинами от Брюсселя тяжести бюджетных дефицитов, что привело к особенно острому кризису суверенного долга. Но и во всех прочих государствах-членах мировой кризис, с точки зрения критериев Пакта, ухудшил состояние дел в государственных финансах, так как упали налоговые поступления и выросли расходы правительств на спасение национальных банков и выплату пособий по безработице.

В конце 2009 г. Комиссия призвала государства-члены вернуться к соблюдению критериев Пакта к 2013-2015 гг. 13 декабря 2011 г. на основании шести базовых актов ${ }^{257}$ («sixpack»), принятых европейской легислатурой по предложению Комиссии, вступил в силу укрепленный ПСР. На этот раз его дополнил новый набор правил по надзору за национальной экономической и бюджетной политикой.

При угрозе превышения нормативов по дефициту госбюджета и госдолгу ЕК должна была предупреждать правительство страны о необходимости исправить положение в течение полугода в соответствии с рекомендациями, которые формально исходили от Совета

\footnotetext{
${ }^{256}$ Jones Erik (2004) European Monetary Union and the Problem of Macroeconomic Governance // Europe Today: National Politics, European Integration, and European Security / Ed. by Ronald Tiersk - Oxford: Rowman and Littlefield.

${ }^{257}$ Regulations: Regulation (EU) No 1173/2011 of the European Parliament and of the Council of 16 November 2011 on the effective enforcement of budgetary surveillance in the euro area;Regulation (EU) No 1174/2011 of the European Parliament and of the Council of 16 November 2011 on enforcement measures to correct excessive macroeconomic imbalances in the euro area;Regulation (EU) No 1175/2011 of the European Parliament and of the Council of 16 November 2011 amending Council Regulation (EC) No 1466/97 on the strengthening of the surveillance of budgetary positions and the surveillance and coordination of economic policies ;Regulation (EU) No 1176/2011 of the European Parliament and of the Council of 16 November 2011 on the prevention and correction of macroeconomic imbalances;Council Regulation (EU) No 1177/2011 of 8 November 2011 amending Regulation (EC) No 1467/97 on speeding up and clarifying the implementation of the excessive deficit procedure.Directive:Council Directive 2011/85/EU of 8 November 2011 on requirements for budgetary frameworks of the Member States. Эти тексты см. по адресу: http://ec.europa.eu/economy_finance/economic_governance/index_en.htm.
} 
министров (а по сути от Комиссии). В противном случае ещё на превентивной стадии (до превышения нормативных показателей) в отношении стран еврозоны возможными становились меры принуждения в форме депозита в размере до 0,2\% ВВП с начислением процентов (он возвращается, если и когда будут произведены требуемые улучшения).

В отличие от прежнего порядка, меры принуждения, формально исходящие от Совета ЭКОФИН, действующего по рекомендации Комиссии, налагаются полуавтоматически. Отказ от такой рекомендации, если она поступила, требует поддержки квалифицированного большинства голосов в Совете, которое должно быть получено в срок до десяти дней (т.е. для введения рекомендованных санкций Совету голосовать не нужно - достаточно просто не реагировать) ${ }^{258}$. Комиссия именует такую процедуру, которая сильно повышает ее собственную свободу манёвра (дискреционную власть) в качестве агента Совета, перевернутым квалифицированным большинством (у Совета есть возможность наложить на такое решение своеобразное отменительное вето).

Превентивная часть ПСР предписывает каждому государству-члену свою среднесрочную цель по бюджету (ССЦ), которая призвана укрепить стабильность государственных финансов. Новыми правилами устанавливается «эталонный показатель по расходам», чтобы помочь оценить прогресс на пути к достижению ССЦ. Такой показатель кладет предел ежегодному росту госрасходов в зависимости от среднесрочных темпов роста национальной экономики. Для тех государств, которые ещё не достигли своих ССЦ, темпы нарастания госрасходов должны быть ниже темпов их экономического роста, что гарантирует общий удовлетворительный результат. Подобным способом, обеспечив адекватное финансирование планов по расходам эквивалентными постоянными доходами, государствачлены, как надеялись в ЕС, могли бы наладить бюджетное планирование и улучшить свои показатели по части финансовой стабильности.

При наличии достаточного финансирования уровень госрасходов Брюсселем не ограничивается. Государства-члены по-прежнему вольны вводить такие налоги, какие они считают нужным, на том уровне, на каком они этого хотят, как и выбирать, на что именно расходовать средства национального бюджета.

Новыми правилами было повышено значение критерия по государственному долгу, за соблюдением которого в прошедшие годы, как мы помним, практически не следили. Когда планка госдолга в 60\% от ВВП превзойдена, в отношении страны еврозоны, допустившей такое, даже в том случае, если дефицит госбюджета не превышает $3 \%$ от ВВП, отныне должна быть применена процедура чрезмерного дефицита - вплоть до наложения санкций в форме беспроцентного депозита размером до 0,2\% ВВП. Депозит при невыполнении мер коррекции обращается в штраф, уже не подлежащий возврату. Здесь также действует описанное выше правило перевернутого большинства.

Таким образом, государство, у которого дефицит или долг выше референтных значений, может быть подвергнуто процедуре чрезмерного дефицита (корректирующая часть ПСР). Если в период финансового кризиса в 2011 г. она действовала в отношении 24 стран $\mathrm{EC}^{259}$, то в настоящее время процедура чрезмерного дефицита не закрыта только в отношении Испании ${ }^{260}$.

\footnotetext{
${ }^{258}$ European Council, "Council Directive 2011/85/EU of 8 November 2011 on Requirements for Budgetary Frameworks of the Member States.," Official Journal of the European Union. L 306/41 (November 8, 2011), http://eur-lex.europa.eu/LexUriServ/LexUriServ.do?uri=OJ:L:2011:306:0041:0047:EN:PDF.

${ }^{259}$ См.: Туркина A.В. (2017) Новые стадии процедуры чрезмерного дефицита бюджета государств - членов Европейского союза и оценка их эффективности // Вестник Балтийского федерального университета им. И. Канта. Сер.: Гуманитарные и общественные науки, № 4, с. 11-17.

${ }^{260}$ Совет министров ЕС открыл процедуру чрезмерного дефицита в отношении Испании 27 апреля 2009 г. В августе 2016 г. Испании было предложено выправить ситуацию к 2018 г. После устойчивой коррекции чрезмерного дефицита в отношении Испании будет действовать превентивная часть ПСР, побуждая её правительство к достижению достаточного прогресса на пути к достижению ССЦ.
} 
Процедура чрезмерного дефицита запускается (после учета всех относящихся к делу факторов, а также влияния экономического цикла), если разница между реальным уровнем госдолга долга и 60\%-ным показателем не станет сокращаться на 1/20 ежегодно (в среднем в течение трех лет). Всем странам, в отношении которых процедура уже открыта, предоставляется трехлетний период с момента его коррекции для перехода к выполнению рекомендаций по сокращению долга. Однако негативная оценка их усилий по сокращению долга в этот переходный период может привести к возобновлению в отношении данной страны процедуры чрезмерного дефицита.

Впрочем, наложение санкций в рамках данной процедуры опять-таки не было задействовано. В 2016 г. Европейская комиссия рекомендовала ввести санкции в отношении не только Испании, но и Португалии (в 2015 г. дефицит государственного бюджета составил в Испании 5,1\%, в Португалии - 4,4\%). В июле 2016 г. Совет поддержал введение санкций против этих двух стран за неспособность принять эффективные меры для устранения проблемы. С этим мнением согласился и ЭКОФИН, но в результате Совет всё же решил их не штрафовать, когда Комиссия, смягчившись, предложила дать Испании и Португалии дополнительное время для снижения дефицита, учитывая переживаемые этими странами социальные проблемы и в особенности высокую безработицу ${ }^{261}$.

Так как за прошедшее десятилетие в Евросоюзе были зафиксированы серьезные различия в конкурентоспособности отдельных государств-членов, а также крупные макроэкономические дисбалансы, для их обнаружения и коррекции в том же законодательном пакете «six-pack» был предусмотрен механизм наблюдения и принуждения к исправлению ситуации, а именно обновлённая процедура чрезмерных дисбалансов. Она опирается на статью 121.6 ДФЕС и включает следующие основные элементы:

- превентивные меры и средства коррекции. На ранней стадии, пока дисбалансы ещё невелики, Комиссия и Совет могут давать национальным правительствам рекомендации для предотвращения их нарастания. В более серьёзных случаях для провинившегося государствачлена может быть запущена упомянутая ранее процедура. В её рамках такое государство-член должно будет представить Комиссии план корректирующих действий, содержащий четкую дорожную карту и сроки исполнения. Наблюдение со стороны ЕК усилено за счёт того, что государство-член должно будет регулярно отчитываться перед ней о достигнутых успехах на пути к исправлению.

- жеёсткое принуждение. Для стран зоны евро предусмотрен метод, включающий две стадии. После единственной неудачи с выполнением рекомендованных корректирующих действий на такую страну может быть наложена санкция в форме депозита с начислением процентов. После второго провала этот депозит может быть обращён в невозвратный штраф (до $0.1 \%$ от ВВП). Санкции также могут быть применены за двукратную неготовность представить удовлетворительный национальный план корректирующих действий. Все решения, ведущие к санкциям, вводятся в силу с подачи Еврокомиссии с применением перевёрнутого квалифицированного большинства в Совете (см. выше), при котором государствам-членам в принципе трудно сформировать блокирующее большинство, что делает такую меру полуавтоматической.

Таким образом, изменениями, произведенные на основании «six-pack», были оговорены три правила: (1) выверенное в цифровом выражении сближение со среднесрочной целью по структурному балансу; (2) коррекционный механизм, включающийся при существенном отклонении от среднесрочной цели; и (3) возможное постепенное включение санкций за неоднократные нарушения.

261 Совет ЕC решил не штрафовать Испанию и Португалию за чрезмерный дефицит бюджета. URL: https://www.newsru.com/finance/09aug2016/eunofine.htmlhttps://www.newsru.com/finance/09aug2016/eunofine.html. 
Жёсткое применение ПСР и последовательная имплементация структурных реформ, к сожалению, могут благоприятствовать рецессии и разрушающе действовать на европейскую экономику и социальную модель. Учитывая это, Комиссия сегодня считает большую гибкость в применении Пакта оправданной. Исходя из подобных соображений, 13 января 2015 г. ЕК выпустила указания для Европейского парламента, Совета, ЕЦБ, Европейского инвестиционного банка, Экономического и социального комитета и Комитета регионов, которыми подобная гибкость распространяется на интерпретацию соответствующих правил как Комиссией, так и Советом - в тех случаях, когда они прилагаются к отдельным странам. Но тем самым в принципе повышается и степень политизации принимаемых ЕК экономических решений, которые лишаются флёра автоматизма.

Меморандум Комиссии о «Наилучшем применении гибкости в контексте существующих правил Пакта стабильности и роста» был поддержан Советом министров ЕС в феврале 2016 г. Декларируемая цель внедрения большей «гибкости» - содействие привлечению государственных и частных инвестиций и предоставление странам с бюджетными проблемами большего времени на исправление ситуации без ущерба для решения социальных проблем. По факту именно Комиссия наделяется при этом способностью отступить от автоматизма в применении ПСР по собственному усмотрению (дискреционной властью). Но в то же время в результате внедрения «гибкости» процедура реализации ПСР усложняется, всё больше запутывается, что ставит в повестку дня задачу её упрощения. Если Пакт становится чрезвычайно сложным и сочетает множество задач и целей, включая содействие наращиванию инвестиций, то выполнение его основополагающей цели по выправлению бюджетной ситуации в национальных рамках может пострадать.

Если судить с институциональной точки зрения, то реформа ПСР 2011 г. внесла достаточно важные изменения в распределение компетенций между национальным и наднациональным уровнем власти в сфере макроэкономической политики в еврозоне. Основанная на жёстких правилах координация национальных курсов формально была продолжена с большей настойчивостью. С помощью регулятивных средств централизованный на европейском уровне контроль над национальной экономической политикой, в особенности бюджетно-налоговой политикой, был расширен и углублён. Государства-члены оказались под тщательным наблюдением. Санкции как крайняя мера в отношении нарушителей ПСР укрепились (пусть только на бумаге). Появились дополнительные условия, при которых Комиссия может предложить государствам-членам скорректировать свою позицию по национальному бюджету.

Позже к пакету «six-pack», реформировавшему Пакт стабильности и роста, добавились ещё два регламента (законодательный пакет «two-pack») по укреплению макроэкономической координации и по наблюдению за бюджетными процессами в странах зоны евро. Они вступили в силу в мае 2013 г.

Эти два регламента нацелены, в особенности, на страны зоны евро (но касаются также и не входящих в еврозону стран ЕС), у которых есть чрезмерные дефициты и которые переживают при этом период финансовой нестабильности или рискуют в неё погрузиться либо уже являются объектами реализации программы внешней финансовой помощи.

Регламент по мониторингу и оценке бюджетных планов содержит следующие основные моменты:

- Если государство-член испытывает серьёзные трудности в поддержании финансовой стабильности или получает финансовую помощь с профилактическими целями, то исполнение им общих для ЕС бюджетных правил должно подлежать ужесточённому мониторингу;

- Государства зоны евро должны ежегодно сдавать Комиссии и Еврогруппе проекты своих бюджетных планов на следующий год, наряду с независимым макроэкономическим прогнозом, на котором они основываются; 
- Комиссия анализирует, согласуется ли представленный проект бюджета с ПСР и рекомендациями, полученными в ходе европейского семестра;

- Если Комиссия приходит к выводу, что проект бюджетного плана демонстрирует серьезные расхождения с ПСР, она может потребовать от национальной власти его изменить. В ином случае Комиссия может изложить государствам-членам, которых это касается, своё мнение, которое, помимо прочего, будет обсуждаться в Еврогруппе.

Так, в ноябре 2017 г. Комиссия обнародовала оценку соответствия проектов бюджетных планов 18 стран-членов зоны евро (за исключением Греции, в отношении которой ещё действовала на тот момент программа стабилизационной поддержки по линии ЕМС) положениям ПСР 262 . Для шести стран (Германия, Латвия, Литва, Люксембург, Нидерланды, Финляндия) было признано полное соответствие таким требованиям, для пяти (Ирландия, Кипр, Мальта, Словакия и Эстония) - соответствие требованиям в целом при наличии опасности отклонения от среднесрочной цели для каждой страны или путей корректировки, приближающих к ней, но ещё для пяти стран (Австрия, Бельгия, Италия, Португалия и Словения) представленные проекты национальных бюджетов были расценены Комиссией как несущие риск несоблюдения требований ПСР. Для Франции и Испании, подлежавших на тот момент действию корректирующей части ПСР, были представлены более подробные (но при этом относительно оптимистичные) прогнозы.

Таким образом, данный регламент дополняет превентивную часть ПСР, обеспечивая интеграцию европейских рекомендаций в предварительные наметки национальных бюджетов и наращивая групповое давление стран еврозоны на «отстающих». Одновременно с тем национальные парламенты продолжаю сохранять формальный суверенитет при голосовании по бюджету страны.

Основные пункты регламента по укреплению наблюдения за государствами еврозоны, переживающими экономические трудности, следующие:

- государства еврозоны, переживающие серьезные трудности или рискующие с ними столкнуться, подвергаются усиленному наблюдению по решению Комиссии. Оно, в свою очередь, включает:

--обязательство государств-членов принимать меры, направленные на источник возникшей нестабильности;

--регулярные проверки и предоставление такими государствами по запросу более детальной информации - проверки осуществляет Комиссия в контакте с ЕЦБ и европейскими надзорными ведомствами, а также МВФ;

--ежеквартальные отчеты Комиссии рабочей группе Еврогруппы, а также Экономическому и финансовому комитету Европейского парламента.

В целом пакет «two-pack» сказался на распределении власти по вертикали (породил более чёткую иерархию в бюджетной области между европейским «центром» и государствами-членами) и по горизонтали (Комиссия обрела большую автономию относительно Совета).

В дополнение к этому, в начале 2013 г., как часть общей стратегии по разрешению кризиса суверенных долгов в еврозоне, вступил в силу межправительственный Договор о стабильности, координации и управлении (Treaty on Stability, Coordination and Governance), с Фискальным пактом (Fiscal Compact) в качестве его ключевого компонента. В марте 2012 г. его подписали 25 государств - членов Евросоюза.

Инициатором Фискального пакта выступила в октябре 2010 г. Германия, которую в данном вопросе поддержала Франция. Он выглядел как попытка ключевых стран еврозоны гарантировать возврат займов, предоставляемых странами с сильнейшими экономиками

\footnotetext{
${ }^{262}$ European Commission. Communication from the Commission. 2018 Draft Budget Plans: Overall Assessment. Brussels, 22.11.2017 COM(2017) 800 final. P. 3.
} 
еврозоны странам её «периферии». Фискальный пакт, т.е. требование зафиксировать правило сбалансированного бюджета в национальных правовых порядках, основан на представлениях о том, что, по мере перехода суверенного долга от частных финансовых институтов к европейским инстанциям, риск для третьих стран еврозоны подхватить «заразу» суверенного дефолта в европейском банковском секторе падает, тогда как долговое бремя перемещается на плечи правительств-заёмщиков, которые обязаны проводить меры жесткой экономии.

В Фискальном пакте участвуют все 19 государств зоны евро и другие члены ЕС (Болгария, Дания и Румыния) - за исключением Великобритании, Чехии и Хорватии. Формально это соглашение действует вне договорных рамок Европейского союза, но с особым акцентом на участии в нём государств еврозоны. В соглашении четыре ключевых компонента ${ }^{263}$. Во-первых, так называемое золотое правило. Оно гласит, что общий структурный дефицит (соотношение налоговых поступлений и текущих расходов с поправкой на изменения в деловом цикле) не должен превышать $0.5 \%$ для стран с государственным долгом свыше $60 \%$ от ВВП или 1.0\% для стран, у которых менее высокий госдолг. Задача определения параметров делового цикла отдельных стран ложится на ЕК при участии государств-членов (и возможности для них оспаривания её оценок). Золотое правило применяется в сочетании с традиционными Маастрихтскими критериями: по дефициту госбюджета - в $3 \%$ от ВВП и по госдолгу - в $60 \%$ от ВВП. К ним добавлено условие, по которому страны, ратифицировавшие Фискальный пакт, должны ежегодно сокращать свой сверхлимитный государственный долг на одну двадцатую от разницы между его нынешней величиной и искомыми $60 \%$ от ВВП.

Во-вторых, соответствующие положения по сбалансированию бюджета должны были быть имплементированы в национальное законодательство документами «обязательной силы и постоянного характера», предпочтительно - включены в национальную конституцию по примеру того, как поступила Германия ${ }^{264}$.

Суд ЕС, действуя в соответствии со статьей 273 ДФЕС, мог наложить финансовые санкции (до $0.1 \%$ от ВВП), если та или иная страна-участница Фискального пакта не имплементировала должным образом новые бюджетные правила в национальное законодательство. В случае со страной еврозоны эти средства направлялись бы в постоянный Европейский механизм стабильности, а в случае со страной ЕС, не входящей в еврозону, - в бюджет Евросоюза.

В-третьих, Фискальный пакт фиксировал в договорной форме более жёсткую процедуру чрезмерного дефицита, утвержденную ранее в европейском законодательстве - в «six-pack».

В-четвертых, формальную институционализацию получил так называемый Евросаммит (статья 12 Договора). Это встречи глав государств и правительств стран еврозоны в присутствии председателя Европейской комиссии по вопросам координации экономической политики. Они проводятся не реже двух раз в год, обычно после заседаний Европейского совета в Брюсселе ${ }^{265}$. Первая (на тот момент неформальная) встреча такого плана состоялась 12 октября 2008 г. по предложению французского президента Николя Саркози. К примеру, на заседании в марте 2018 г. лидеры 19 стран еврозоны обсуждали вопросы долговременной реформы ЭВС, включая предложения по созданию для еврозоны отдельного бюджета (fiscal (apacity $)^{266}$.

\footnotetext{
${ }^{263}$ Подробнее об см.: Broin Peadaro (2012) The Euro Crisis: The Fiscal Treaty - an Initial Analysis // Institute of International and European Affairs Working Paper, n 5.

${ }^{264}$ В Основном Законе ФРГ было зафиксировано обязательство федерального правительства начать сокращение своего структурного дефицита, чтобы выйти на среднесрочную цель в $0.35 \%$ от ВВП к 2016 г.

265 Правила организации Евросаммитов см. по адресу:
} http://www.consilium.europa.eu/media/20377/qc3013400enc_web.pdf.

266 Подробнее см.: http://www.consilium.europa.eu/en/meetings/euro-summit/2018/03/23/ 
С одной стороны, оговоренные в соглашении требования являются обязательными только для стран еврозоны, а для остальных участников они носят характер пожеланий - до тех пор, пока последние не перейдут на евро, или ранее, если они того пожелают (эти страны вольны выбрать только те отдельные положения Фискального пакта, которым они готовы следовать в обязательном порядке). С другой стороны, только государства, ратифицировавшие рассматриваемое соглашение, смогут в случае острой нужды претендовать на финансирование из средств ЕМС.

Фискальный пакт заложил некую основу для дальнейшего укрепления и согласования национальной экономической политики в еврозоне, в том числе введя предварительную координацию выпуска долговых обязательств стран-участниц и программы экономического партнёрства для государств-членов, попавших под действие процедуры чрезмерного дефицита. В этих программах детально прописываются структурные реформы, которые требуются для эффективной и долговременной коррекции переживаемых конкретными странами проблем.

При всём том значение Фискального пакта не следует преувеличивать. Это своего рода «рамочное решение» 267 , иными словами - политический компромисс, которого правительствам стран ЕС удалось достичь, несмотря на значительное расхождение интересов между ними. Зачастую рамочные решения в принципе «не предполагается имплементировать, коль скоро их реализация сулит вынести непримиримые конфликты на поверхность» ${ }^{268}$.

Как отмечает, в частности, российский эксперт Анна Цибулина, система управления в рамках Фискального пакта весьма запутанная, что затрудняет принятие решений. Не облегчает ситуацию в этом плане и имеющая место дифференциация (деление участников на страны зоны евро; страны, не перешедшие на евро, подписавшие Договор; страны вне зоны евро, не подписавшие Договор $)^{269}$. Фискальный пакт действует вне правового порядка ЕС, а потому вовлечение в его работу европейских институтов (Европейской комиссии и Суда ЕС) является весьма ограниченным, не вполне «легальным». Между нормами, заложенными в Фискальном пакте, и собственно нормами ЕС имеется определённый зазор, коль скоро Фискальный пакт накладывает на правительства участвующих стран сравнительно более жёсткие обязательства в области бюджетной политики. Так, на основании «six-pack» для государства-члена допустим дефицит госбюджета в 1\% от ВВП в момент определения среднесрочной бюджетной цели, тогда как Договор о стабильности, координации и управлении снижает соответствующую планку до $0.5 \%$.

Необязательный характер носят пожелания в заключённом соглашении, которые касаются роли национальных парламентов и расширенного использования продвинутого сотрудничества на Едином внутреннем рынке. По первому вопросу Пакт призывает к развитию сети бюджетных комитетов национальных парламентов и Европарламента в качестве дополнительной арены для обмена наилучшим опытом и для уяснения странами позиций друг друга по фискальным проблемам. По второму вопросу статья 10 межправительственного Договора содержит положение, по которому, в соответствии с общими правилами продвинутого сотрудничества, не менее девяти государств-членов могут использовать институциональные рамки Евросоюза для принятия законодательства, которое будет действовать только применительно к этой группе государств.

В сентябре 2012 г. важное препятствие к вступлению в силу Фискального пакта было снято, когда Федеральный конституционный суд Германии, рассмотрев соответствующие

\footnotetext{
${ }^{267}$ Héritier A. (1999) Policy-Making and Diversity in Europe: Escape from Deadlock, Cambridge University Press, Cambridge.

${ }^{268}$ Ibidem.

${ }^{269}$ Цибулина А.Н. (2013) Экономический и валютный союзы ЕС: работа над ошибками. // Вестник. МГИМОУниверситета, № 4(31), с. 116. C. 113-119. URL: http://ehd.mgimo.ru/IORManagerMgimo/file?id=1F072EE9B30D-B43B-42E8-B6D023E58EE7.
} 
иски ${ }^{270}$, разрешил завершить его ратификацию в Германии, как и Договора о постоянном Европейском механизме стабильности. Фискальный пакт начал действовать с 1 января 2013 г.

В межправительственном Договоре о стабильности, координации и управлении в экономическом и валютном союзе (статья 16) было предусмотрено, что через пять лет после его вступления в силу (т.е. к 1 января 2018 г.) будут предприняты шаги по перенесению его содержания непосредственно в договорную основу функционирования ЕС. Ведь Фискальный пакт изначально был предложен в качестве изменения к Договору о функционировании Европейского союза и только вынужденно обрёл нынешний формат после того, как по этому вопросу не удалось добиться единогласия в Европейском совете (в первую очередь этому воспротивилась Великобритания).

6 декабря 2017 г. Европейская комиссия, не будучи связана в правовом отношении положениями межправительственного Договора, принятого вне правовых рамок ЕС, тем не менее, выступила с законодательным предложением по данному поводу, пригласив Совет и ЕП принять соответствующий акт к середине 2019 г. Но до тех пор, пока Фискальный пакт не будет включён в договорную основу интеграции, его фактическое значение останется несущественным. Он не слишком отличается от исходящих от ЕС политических деклараций (подобных заключениям Совета министров), т.е. в большей мере выполняет символическую роль. В то же время мы можем даже усомниться в том, что перенос основных положений Фискального пакта в договорную основу функционирования ЕС вообще когда-нибудь произойдёт.

Результаты действия реформированного ПСР на сегодняшний день остаются довольно противоречивыми. Пакт был выстроен на постулате, согласно которому членам валютного союза нужна жёсткая бюджетная дисциплина, чтобы уровни долга отдельных стран оставались в разумных пределах, не ставя под угрозу саму единую валюту. Такую точку зрения поддерживали, прежде всего, в ЕЦБ и в правительстве Германии, и именно она возобладала в устройстве ПСР, который стимулирует правительства на сокращение государственных расходов и на проведение либеральных структурных реформ, повышающих гибкость рынка труда, а также на снижение налогов и повышение доходов частных компаний. Но ПСР не ставит впрямую целей содействия экономическому росту. Правительства же согласились на такой пакт, потому что подобную доминирующую идеологию разделяли их национальные технократы.

При всём том зафиксированные цели - 60\% от ВВП по государственному долгу и дефицит госбюджета не более 3\% - по сути, лишены актуального экономического смысла, в известном смысле устарели, будучи избраны, исходя из практики 1990-х годов. В исходном варианте Пакт не предусматривал особых обстоятельств, при которых отдельным странам резонно было бы временно выйти за оговорённые пределы. Со временем в применении условий Пакта, как уже было упомянуто, наметилась большая гибкость. Однако, по большому счёту, по оценке многочисленных критиков, он остаётся достаточно примитивным фискальным «ярмом», которое не может служить убедительным «умным» решением макроэкономических проблем в неопределённой обстановке глобализированной экономической системы 21 века. Его действие оказывается контрпродуктивным в отношении отдельных стран еврозоны или даже бессмысленным, когда приходит серьёзный экономический кризис.

\footnotetext{
270 Суть претензий истцов, действовавших от имени 37 тыс. граждан ФРГ, отдельных партий и политиков, сводилась к тому, что Фискальный пакт и ЕМС противоречат Основному закону ФРГ, лишая национальный парламент бюджетного суверенитета.
} 


\section{Европейский семестр}

Начиная с 1990-х годов, европейские институты весной каждого года обсуждали экономическую политику, а осенью изучали состояние дел в области бюджетной (фискальной) политики, но с 2010 г. был согласован иной график - так называемый европейский семестр. Речь идёт о канале более интрузивного вовлечения европейских институтов в ежегодный процесс подготовки национальных бюджетов. Европейский семестр призван обеспечить их комплексное и последовательное рассмотрение (вкупе с мониторингом макроэкономических дисбалансов и проблем финансового сектора, которые ранее вообще плотному систематическому наблюдению в ЕС не подвергались). Целью европейского семестра, таким образом, являются совершенствование координации на европейском уровне курсов национальной экономической политики и более чёткая имплементация в национальных рамках экономических правил ЕС. Он основывается на уверенности в том, что национальные приоритеты государств-членов не должны входить в конфликт с экономической политикой, которая согласована на уровне Европейского союза.

В данном случае мы наблюдаем очередную коррекцию распределение власти между ЕС и национальными правительствами, которая происходит без внесения изменений в основополагающий Договор. Согласно новому графику, на уровне Евросоюза фискальная политика, макроэкономические дисбалансы, вопросы финансового сектора и стимулирующие рост экономики структурные реформы теперь обсуждаются совокупно в первой половине года (точнее, с февраля по июль включительно). Затем, во второй половине года («национальный семестр»), правительства довершают разработку национальных бюджетов в соответствии с уже сделанными намётками и потом представляют их на рассмотрение своих парламентов. Организованный таким образом контроль европейского уровня распространяется не только на государственные финансы, но и на отслеживание изменений в конкурентоспособности государств-членов.

Первый европейский семестр был запущен в январе 2011 г. Со времени начала его работы как интенсивного механизма предварительного (ex ante) европейского руководства и социализации национальных чиновников экономического блока управления ему уделяется существенное внимание в зарубежных, прежде всего европейских, экспертных кругах. Во многих аналитических работах особый акцент сделан на том, как к этому процессу адаптируются национальные парламенты ${ }^{271}$. Аналитики зачастую приходят к выводу, что если в северной части интегрированной Европы соответствующие полномочия национальных парламентов удалось обеспечить либо даже развить, то в южной её части парламенты по факту, напротив, лишились части своих прежних полномочий, в том числе из-за внешнего экономического и политического давления на соответствующие правительства.

Осенью каждого года Европейская комиссия устанавливает экономические и социальные приоритеты Европейского союза на следующий год в Ежегодном обзоре экономического роста (Annual Growth Survey) ${ }^{272}$ и (совместно с Советом министров) в Докладе

\footnotetext{
${ }^{271}$ Cooper Ian (2017) A Separate Parliament for the Eurozone? Differentiated Representation, Brexit, and the Quandary of Exclusion // Parliamentary Affairs, Volume 70, Issue 4, pp. 655-672. URL: https://doi.org/10.1093/pa/gsx022; Maatsch Aleksandra (2015) Empowered or Disempowered? The Role of National Parliaments during the Reform of European Economic Governance // MPIfG Discussion Paper, 15/10. URL: http://www.mpifg.de/pu/mpifg_dp/dp1510.pdf; Crum Ben (2017) Depoliticisation versus Accountability: What Role for Parliaments in Post-Crisis EU Economic Governance // Journal of European Public Policy, Volume 25, 2018 - Issue 2: SI: EU Socio-Economic Governance since the Crisis: The European Semester in Theory and Practice, pp. 268-286. URL: https://www.tandfonline.com/doi/abs/10.1080/13501763.2017.1363270.

272 Ежегодный обзор на 2018 г., обнародованный 22 ноября 2017 г., см. по адресу: https://ec.europa.eu/info/sites/info/files/2017-comm-690_en_0.pdf.
} 
по занятости (Joint Employment Report) ${ }^{273}$. Эти документы содержат также общие указания о приоритетных действиях, которые должны быть предприняты на национальном уровне (по вопросам инвестиций, структурных реформ и бюджетной консолидации, а также по политике в области стимулирования занятости ${ }^{274}$ ). Комиссия Евросоюза публикует свои мнения по проекту бюджета каждой страны на следующий год. После этого годовой цикл открывается в феврале обсуждением названных документов. Весной государства-члены передают в Комиссию свои программы стабильности (для стран еврозоны) и программы конвергенции (для остальных стран ЕС), которые содержат их (скорректированные при необходимости) планы по национальным бюджетам, а также национальные программы реформирования (о структурных реформах и о мерах по стимулированию роста и занятости). Комиссия оценивает эти документы. Она даёт конкретные рекомендации каждой стране по бюджетным и экономическим вопросам.

Таким образом, в феврале рекомендации Комиссии проходят обсуждение в Совете. Тогда же Комиссия публикует отчёт по странам, анализируя их экономическое состояние и прогресс, достигнутый в осуществлении реформ. В апреле страны предоставляют свои национальные планы реформ, а также программы стабильности и конвергенции (трёхлетние бюджетные планы) в Комиссию. Комиссия оценивает эти планы и в мае представляет серию новых рекомендаций по отдельным странам. Июньский саммит Европейского совета обсуждает эти рекомендации, а Совет в июле должен их принять (в них могут быть внесены изменения). Рекомендации, которые сделаны той или иной стране в рамках действующей процедуры чрезмерного дефицита или чрезмерного дисбаланса, являются для этой страны обязательными.

К 15 октября каждого года страны еврозоны должны сдать в Комиссию очередные проекты бюджетных планов, которые Комиссия оценивает на основании требований ПСР и ранее сделанных конкретных страновых рекомендаций и обнародует мнения по каждому из них в ноябре. Затем они подлежат обсуждению на заседании Еврогруппы. Помимо прочего, на всех стадиях европейский семестр сопровождается партнёрским наблюдением, т.е. некой формой контроля над национальным правительством со стороны «коллег по цеху» из других стран ЕС, без непосредственного привлечения к делу европейских инстанций.

Инструменты наблюдения, которые применяются на уровне ЕС в области координации экономической политики, можно разделить на три категории: это (1) надзор за макроэкономическими дисбалансами, (2) надзор за государственными финансами и (3) контроль за выполнением целей стратегии «Европа-2020».

1. Ежегодный цикл процедуры по макроэкономическим дисбалансам (Macroeconomic Imbalance Procedure, MIP) начинается каждый год с выпуска Доклада по механизму предупреждения (Alert Mechanism Report, AMR), который Европейская комиссия публикует в ноябре наряду с Ежегодным обзором экономического роста. В этом Докладе применяется набор специально подобранных индикаторов и индикативных пороговых величин, что позволяет отслеживать потенциальные экономические дисбалансы в отдельных странах, требующие политических действий. Такая оценка опирается и на другие экономические, социальные и финансовые индикаторы, которые не входят в основной набор. На этом основании в Докладе указываются страны, которые требуют более углублённой проверки и скрининга, позволяющего выявлять конкретные уязвимости и макроэкономические риски. По завершении такой работы, которая входит в «зимний пакет» европейского семестра и

\footnotetext{
${ }^{273}$ См.: https://ec.europa.eu/info/sites/info/files/2017-comm-690_en_0.pdf. Совместный доклад по занятости на 2018 г. впервые оценивает достижения каждой страны в соответствии с Европейской опорой социальных прав, провозглашённой в ноябре 2017 г. ЕП, Советом министров и Европейской комиссией. Это инструмент мягкого права, не имеющий обязательной силы.

${ }^{274}$ Проект указаний Совета министров государствам-членам по вопросам политики занятости (Employment Guidelines) см. по адресу: https://ec.europa.eu/info/sites/info/files/2017-comm-690_en_0.pdf.
} 
результаты которой публикуются в феврале, Комиссия определяет наличие либо отсутствие дисбалансов, а также их масштаб. Так, в цикле европейского семестра в 2018 г. в Докладе по механизму предупреждения 12 стран (Болгария, Германия, Ирландия, Испания, Италия, Кипр, Нидерланды, Португалия, Словения, Франция, Хорватия и Швеция) были указаны как нуждающиеся в углублённой проверке. Мониторинг в отношении каждой из указанных стран осуществляется в течение всего года.

2. Надзор за государственными финансами осуществляется в Европейском союзе соответствии с правилами ПСР (его превентивной или корректирующей части, т.е. процедуры чрезмерного дефицита). В 2017 г. процедура чрезмерного дефицита действовала в отношении шести стран Европейского союза (Великобритания, Греция, Испания, Португалия, Франция, Хорватия). Для Великобритании, Греции, Португалии и Хорватии и том же году она была закрыта. Целью превентивных мер является обеспечение здоровья государственных финансов. Все страны должны достичь своей среднесрочной бюджетной цели или приближаться к ней, ежегодно улучшая структурные бюджетные позиции на $0,5 \%$ от национального ВВП в качестве целевого ориентира. При этом в благоприятных экономических условиях они должны добиваться большего, оставляя место для некоторой гибкости в сложный период.

3. Стратегия «Европа-2020» по созданию рабочих мест и поддержке роста, предполагающая экономические и социальные реформы, с учётом экологических ограничения, была одобрена в июне 2010 г. Её ключевые цели включили:

- достижение 75-процентной занятости для населения в возрасте от 20 до 64 лет;

- повышение до 3\% от совокупного ВВП Европейского союза государственных и частных инвестиций в научные исследования, разработки и инновации;

- снижение выбросов парниковых газов на 20\% (или на 30\% при благоприятных условиях) от уровня 1990 г.; доведение до 20\% доли возобновляемых источников в энергопотреблении; 20-процентное повышение энергоэффективности;

- снижение менее чем до 10\% числа школьников, покидающих школу с неполным средним образованием; повышение не менее чем до 40\% числа жителей в возрасте от 30 до 34 лет, имеющих высшее образование;

- сокращение на 20 млн. числа лиц, находящихся на грани или за гранью нищеты и социальной отверженности.

Эти цели являются неотъемлемой частью ежегодной инвентаризации национальных курсов в рамках Европейского семестра. На их основе государства-члены устанавливают собственные ориентиры в каждой области, соответствующие специфике национальных стартовых позиций. При этом государства соотносят свою экономическую политику с Интегрированными направлениями экономической политики (ИНЭП), принятыми на уровне EC.

ИНЭП выступают главным (мягким) инструментом координации в данной области. Они носят форму не требующих обязательного исполнения указаний Совета министров ЕС государствам-членам по макроэкономической политике, структурным реформам и политике занятости. Здесь санкций обычно не предусматривается, но в то же время ИНЭП можно назвать политически обязательными (что не отменяет самой возможности отступления от предписанного и обещанного). Соблюдение европейских рекомендаций и взятых на себя обязательств обеспечивается в основном опасением репутационных потерь и давлением успешных стран в отношении отстающих. На основании Интегрированных направлений каждое государство-член разрабатывает собственную национальную программу реформирования (НПР), описывая в ней ключевые национальные приоритеты в области экономических реформ и собственные заданные показатели по ним. ИНЭП охватывают ключевые сегменты социально-экономической политики в Европейском союзе, но всё равно 
охват этот не полный, несбалансированный. Из него выпадают экологическая политика и политика сплочения.

Для упрощения мониторинга по странам, в отношении которых действуют программы внешней финансовой помощи, наблюдение по линии ПСР, по имплементации процедуры макроэкономического дисбаланса и по европейскому семестру специально не проводится, поскольку эти страны и так являются объектом широкомасштабного пристального контроля со стороны европейских и международных инстанций.

Европейский семестр - инструмент мягкого управления. С его помощью Комиссия осуществляет мониторинг соблюдения в отдельных странах жёстких (бюджетных) и мягких (социально-экономических) критериев, но она не в состоянии наложить вето на решения по национальному бюджету (такие решения являются суверенными). По сей день ни одно из правительств, нарушивших какие-то из этих критериев, так и не было подвергнуто наказанию со стороны ЕС (что в принципе возможно). Недаром, по мнению многих авторов, европейский семестр, будучи мягкой формой канализации институтами ЕС действий национальных правительств, заведомо неэффективен ${ }^{275}$, не приносит достаточного успеха в структурных реформах и наращивании инвестиций, из-за чего валютная политика ЕС (рассмотренная нами во второй главе) перегружена ответственностью по амортизации и нейтрализации неблагоприятных экономических тенденций (на неё ложиться большая нагрузка).

Действительно, если понимать искомую эффективность европейского семестра как успешную национальную имплементацию указаний, поступающих со стороны институтов EC, то она остаётся невысокой. В тех случаях, когда, по мнению Комиссии, государства-члены не демонстрируют в этом смысле существенного прогресса, рекомендации ЕК по отдельным странам могут не меняться (повторяться) из года в год или становятся всё более детальными при сохранении сути претензий. Как замечает, к примеру, Соня Беккер, досконально изучившая данный вопрос на примерах Германии, Польши, Испании и Франции, это «не влечёт за собой непременной конвертации её (Комиссии - M.C.) предложений в национальную практику» ${ }^{276}$.

Институты ЕС, отвечающие за экономическое управление в Еврозоне (прежде всего Совет министров в формате ЭКОФИН и Комиссия), так и не получили полноценной возможности адекватно реагировать на колебания экономической конъюнктуры и на дисбалансы внутри интегрированной Европы (между странами с активным платёжным балансом и странами, имеющими дефициты.) Надзор над национальной экономической и бюджетной политикой не сфокусирован в достаточной мере не случаях возможных негативных трансграничных влияний, а соблюдение на национальном уровне европейских критериев чаще скорее внешнее, процедурное, нежели сущностное.

Именно это, в первую очередь, ставит под вопрос как эффективность европейского семестра, так и демократическую легитимность предоставленных европейским институтам прав по вмешательству в национальные курсы бюджетной и экономической политики. Европейский семестр вряд ли может быть действенным, если он недостаточно легитимен тогда как именно европейским институтам принадлежит в нём ключевая роль. Но его легитимность, в конечном счёте, зависит от меры вовлечения в процесс национальных парламентов. Между тем, к примеру, в рамках процедуры по европейскому семестру график сложился таким образом, что национальные правительства (исполнительная власть) направляют свои бюджетные планы на рассмотрение Европейской комиссии ещё до того, как

\footnotetext{
${ }^{275}$ Cм.: Darvas Zsolt and Leandro Alvaro (2015) The Limitations of Policy Coordination in the Euro Area under the European Semester // Bruegel Policy Contribution, Issue 2015/19, November. URL: http://bruegel.org/wpcontent/uploads/2015/11/pc_2015_194.pdf.

${ }^{276}$ Bekker Sonja (2016) Is There Flexibility in the European Semester Process? Exploring Interactions between the EU and Member States within Post-Crisis Socio-Economic Governance // Tilburg Law School Research Paper, No. 10/2016. Available at SSRN: https://ssrn.com/abstract=2743238 or http://dx.doi.org/10.2139/ssrn.2743238 .
} 
они подают их в национальные парламенты. В дополнение к тому, комитеты национальных парламентов, учреждённые для надзора над переговорами на европейском уровне, в которых участвуют национальные правительства, не оказывают в этом смысле большого влияния будь то по причине недостатка необходимой квалификации или из-за неполного доступа к информации ${ }^{277}$.

В рамках очередного европейского семестра Комиссия 23 октября 2018 г. отклонила проект бюджета Италии на 2019 г., предложенный новым правительством в Риме (ЕК впервые пошла на такой решительный шаг в отношении страны еврозоны), пригрозив Риму введением санкций. В национальном проекте был запланирован дефицит в размере $2,4 \%$ от ВВП, тогда как с предыдущим итальянским правительством ранее уже была согласована цель по дефициту в $0,8 \%$. Хотя планируемый Римом дефицит не превышает потолка в $3 \%$, в ЕС сочли такой скачок беспрецедентным в истории применения европейских бюджетных правил. Учтём, что государственная задолженность Италии составляет 2,3 трлн. евро, или более $130 \%$ от национального ВВП, а экономический рост равен $0 \%$ (картину долгов по отдельным странам еврозоны см. в таблице 4-1 ниже). Нынешними итальянскими бюджетными планами предусматриваются, в частности, базовый доход для бедных, пенсионные реформы (возможность снижения возраста выхода на пенсию) и снижение налогов. На данный момент Рим отказывается вносить требуемые Брюсселем поправки, ссылаясь на разрушительность продолжающейся европейской политики экономии.

Как можно было убедиться на этих страницах, экономическая координация в Европейском союзе с точки зрения формы может быть жёсткой или более мягкой. Жёсткая координация (бюджетных курсов) осуществляется сверху вниз. Наднациональный властный уровень играет в ней более существенную роль. Здесь вводятся обязательные европейские правила, ограничивающие свободу выбора для правительств. Жёсткая координация подкреплена правовым регулированием, задающим её формальные цели и модальность (формат, круг действующих лиц и роли, которые они исполняют). Тем самым обеспечивается непрерывность взаимодействия европейского и национального властных уровней, особенно важная в стрессовых, кризисных условиях. Но за достижение поставленных целей всё равно отвечают сами национальные правительства.

В случае мягкой координации для продвижения к определённым желаемым целям вырабатываются руководящие указания, многолетние рамочные стратегии. В качестве инструментов для налаживания координации используются не правовые акты, регламенты или директивы, а консультации, поиски консенсуса, дружественная взаимная оценка (реег review) и сопоставительный анализ национального опыта. С одной стороны, Европейская комиссия оказалась наделена существенной дискреционной властью (в особенности при внедрении реформированного Пакта стабильности и роста, процедуры макроэкономических дисбалансов и при оформлении процедуры самого Европейского семестра как такового) ${ }^{278}$. C другой стороны, ЕК не хочет прослыть нарушительницей национального суверенитета. Потому она чаще воздерживается от педалирования вопроса о санкциях в отношении нарушителей европейских экономических правил. Ключевое значение, которое обрели двусторонние отношения Комиссии с каждым из государств-членов, составляют основное (и ценное для ЕК) нововведение в процессе европейского семестра.

Всё только что перечисленное в этом разделе сводится к шагам по углублению европейской интеграции, при котором асимметрия между экономическим и валютным крыльями ЭВС не выправляется, а, напротив, усугубляется. Национальные бюджеты остаются

\footnotetext{
${ }^{277}$ Crum (2017), Op. cit.

${ }^{278}$ Vanheuverzwijn Pierre (2017) How the Commission fills in the blanks of the European Semester // Politique européenne, 2017/1 (No 55), pp. 8-35.
} 
Госдолг в первом квартале 2018 года (в прочентах к ВВП, в порядке убывания)

\begin{tabular}{|c|c|c|c|}
\hline Страна & Госдолг & Страна & ГосдолГ \\
\hline Греция & 180,4 & Ирландия & 69,3 \\
\hline Италия & 133,4 & Германия & 62,9 \\
\hline Португалия & 126,4 & Финляндия & 59,8 \\
\hline Бельгия & 106,3 & Нидерланды & 55,2 \\
\hline Кипр & 103,0 & Словакия & 50,8 \\
\hline Испания & 98,8 & Мальта & 50,4 \\
\hline Франция & 97,7 & Литва & 36,3 \\
\hline Еврозона в среднем & 86,8 & Латвия & 35,8 \\
\hline Австрия & 77,2 & Люксембург & 22,2 \\
\hline Словения & 75,1 & Эстония & 8,7 \\
\hline
\end{tabular}

Источник: National debt in EU countries in the 1st quarter 2018 in relation to gross domestic product (GDP). URL: https://www.statista.com/statistics/269684/national-debt-in-eu-countries-in-relation-to-gross-domestic-product-gdp.

и на перспективу главным финансовым инструментом по реагированию на изменения в европейской экономике. Им отводится главная роль в стабилизации экономики в ЕС, тогда как за функцией экономической стабилизации, которая осуществлялась бы непосредственно на европейском уровне, может оставаться лишь вспомогательная роль. Поэтому от государствчленов Брюссель будет и впредь требовать, в особенности в благодатные времена, наращивания и поддержания финансовых «буферов», как это предусмотрено Пактом стабильности и роста. Только если этих «буферов» и стабилизаторов оказывается недостаточно, в случае крупных асимметричных шоков более значимым и важным становится выполнение стабилизационной функции на уровне ЕС.

\section{Стабилизация экономики}

Пакт стабильности и роста (как, собственно, и Фискальный пакт), вопреки тому, что позволяло предположить его наименование, предназначался вовсе не для того, чтобы непосредственно содействовать экономическому росту и занятости. Но в принципе поддержание высокого и стабильного уровня экономической активности - одна из основных функций (обязанностей) государства в рыночной экономике. Исторически двумя главными возможными экономическими «стабилизаторами» со времен Великой депрессии 1930-х годов называют национальный центральный банк (в качестве кредитора последней инстанции) и национальное правительство, которое в период экономического спада способно проводить контрциклические меры по линии фискальной (бюджетно-налоговой) политики.

На европейском уровне подобные стабилизаторы изначально не были предусмотрены. В кризисных условиях после реализации в 2008-2009 гг. Европейского плана по 
восстановлению экономики (European Economic Recovery Plan ${ }^{279}$ ) EC, напротив, обратился к жёстким ограничивающим мерам и пытался воздействовать на разразившийся кризис проциклически ${ }^{280}$. Но начиная с 2010 г., с развёртыванием внутри еврозоны кризиса суверенных долгов, о стабилизации там стали задумываться серьёзнее. Так, в 2011-2012 гг. Европейский центральный банк начал насыщать банки еврозоны ликвидностью и развернул программу выкупа государственных долгов, т.е. стал подкачивать деньги в экономику с явной целью её стимулирования. Таким образом была сделана заявка на то, что некоторые эксперты позже назовут «фискальной политикой по умолчанию» ${ }^{281}$. Но подобных усилий, предпринимаемых исключительно по линии ЕЦБ, было явно недостаточно.

В целом к числу основных государственных функций в экономике сегодня можно отнести:

1. поддержание рыночной конкуренции и защиту прав потребителей;

2. стимулирование экономического роста;

3. стабилизацию (поддержание устойчивости основных параметров экономики);

4. распределение, или аллокацию (выделение ресурсов для компенсации провалов рынка);

5. перераспределение дохода (в целях обеспечения социальной справедливости).

Среди них ключевыми обычно называют последние три ${ }^{282}$. Само собой разумеется, что в европейской многоуровневой системе управления исполнение подобных функций по определению не может ограничиваться только одним уровнем. Чтобы проиллюстрировать данный тезис, ниже приведена таблица 4-2 по инструментам европейской инвестиционной политики.

Как уже было сказано ранее, в качестве теоретического концепта многоуровневое управление 283 сначала получило развитие при анализе функционирования европейских структурных фондов ${ }^{284}$, т.е. наднационального бюджета. В дальнейшем это понятие было расширено. Помимо собственно нескольких уровней управления и соответствующих им игроков, оно, к примеру, стало включать финансовых посредников и частных инвесторов, которым принадлежит своя заметная роль в политике сплочения $\mathrm{EC}^{285}$.

Чтобы справиться с последствиями глобального финансово-экономического кризиса в 2008-2009 гг., как и последовавшего кризиса суверенных долгов в еврозоне, в практике европейского экономического управления, как мы уже убедились, появилось несколько новых институтов и процедур. Они подтолкнули ЕС по направлению к фискальной интеграции ${ }^{286}$.

\footnotetext{
${ }^{279}$ Commission of the European Communities. A European Economic Recovery Plan. Communication from the Commission to the European Council.COM (2008) 800 final. Brussels, 26.11.2008. URL: http://ec.europa.eu/economy_finance/publications/publication13504_en.pdf. См. также: Лицарева Е. Ю. (2012) Позиции стран ЕС в отношении выхода из экономического кризиса 2008 г. // Вестник Томского $\begin{array}{lllllll}\text { государственного университета, } & \text { № } & 365, & \text { с. } & 70 .\end{array}$ http://vital.lib.tsu.ru/vital/access/manager/Repository/vtls:000438553.

${ }^{280}$ Wolf M. (2014) The Shifts and the Shocks: What We've Learned-And Have Still to Learn-from the Financial Crisis, New York: Penguin. pp. 42-43.

${ }^{281}$ Schelkle W. (2014) Fiscal integration by default // Beyond the Regulatory Polity? The European Integration of Core State Powers / Ed. by P. Genschel and M. Jachtenfuchs - Oxford, England: Oxford University Press, p. 105-123.

${ }^{282}$ Musgrave R. \& Musgrave P. (1989) Public finance in theory and practice, New York, McGraw-Hill, (5th edition).

283 Подробнее см.: Транснациональные политические пространства: явление и практика / Под ред. М.В. Стрежневой - М.: Весьмир, 2011, с. 169-176.

${ }^{284}$ Stephenson P. (2013) Twenty years of multi-level governance: 'Where Does It Come From? What Is It? Where Is It Going? // Journal of European Public Policy, vol. 20, issue 6, p. 817-837.

${ }^{285}$ Dabrowski, M. (2014) EU cohesion policy, horizontal partnership and the patterns of sub-national governance: Insights from Central and Eastern Europe // European Urban and Regional Studies, vol. 21, issue 4, pp. 364-383.

${ }_{286}$ См., например: Худякова Л.С., Сидорова Е.А. (2014) Реформа регулирования финансового сектора в Европейском союзе // Деньги и кредит, №4, с. 33-34.
} 
Однако, как справедливо замечает, например, российский специалист А.Н. Цибулина, пока в Евросоюзе, по большому счёту, сложился, скорее, «превентивный» фискальный союз, который действует «в форме контроля над государственными финансами со стороны ЕК» ${ }^{287}$. Чтобы оправдать отсутствие солидной фискальной функции европейского уровня в предложенном плане валютного союза, комитет Делора в своё время опирался главным образом на принцип субсидиарности ${ }^{288}$.

Таблица 4-2.

Функиии инструментов инвестищионной политики ЕС на разных уровнях управления экономикой

\begin{tabular}{|c|c|c|c|}
\hline Уровни управления & Аллокация & Стабилизация & Перераспределение \\
\hline Субнациональный & $\begin{array}{l}\text { региональные } \text { и } \\
\text { бюджеты, } \\
\text { банки развития }\end{array}$ & Пакт стабильности и роста & $\begin{array}{l}\text { структурные } \\
\text { инвестиционные фонды ЕС, } \\
\text { Европейский } \\
\text { инвестиционный банк }\end{array}$ \\
\hline Национальный & $\begin{array}{l}\text { национальные бюджеты, } \\
\text { европейские гарантии, банки } \\
\text { развития }\end{array}$ & Пакт стабильности и роста & 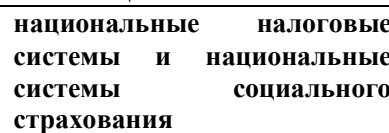 \\
\hline Европейский & $\begin{array}{l}\text { структурные } \\
\text { инвестиционные фонды ЕС, } \\
\text { Европейский } \\
\text { инвестиционный банк }\end{array}$ & $\begin{array}{lr}\text { Европейский } & \\
\text { инвестициннный } & \text { банк, } \\
\text { Европейский } & \text { фонд } \\
\text { финансовой } & \text { стабильности, } \\
\text { Европейский } & \text { механизм } \\
\text { стабильности } & \end{array}$ & $\begin{array}{l}\text { структурные } \\
\text { инвестиционные фонды ЕС, } \\
\text { Европейский } \\
\text { инвестиционный банк }\end{array}$ \\
\hline
\end{tabular}

Источник: Naert Frank (2017) EU governance and the European Fund for Strategic Investment // European Administrative Space: Spreading Standards, Building Capacities / Ed. by I. Kopric \& P. Kovac - Bratislava: NISPAcee, pp. 77-94. URL: https://biblio.ugent.be/publication/8523646/file/8525040.pdf.

В концептуальном плане для целей дальнейшего анализа важно уточнить различие между финансовой стабильностью и экономической стабилизацией. Финансовая стабильность есть такое состояние финансовой системы (ключевых финансовых рынков и системы финансовых институтов), при котором она устойчива относительно экономических шоков и способна безотказно выполнять своё назначение. Среди проблемных факторов, которые могут негативно сказаться на функционировании финансовой системы, в литературе выделяют следующие: слишком быстрая либерализация финансового сектора, неадекватная экономическая политика, ненадёжный механизм обменных курсов, неэффективное распределение ресурсов, слабый надзор, плохая рыночная дисциплина, слабое регулирование аудита и неэффективные бухгалтерские правила. Но в данном случае мы будем говорить не об этом, а о политике стабилизации экономики, которая представляет собой определённую макроэкономическую стратегию. Её реализуют правительства и центральные банки для поддержания стабильных темпов экономического роста, обеспечения ценовой стабильности и борьбы с безработицей. Кроме того, политика стабилизации, цели которой достигаются определёнными действиями в сфере фискальной (бюджетно-налоговой) и денежно-кредитной политики, предназначается для того, чтобы помочь экономике той или иной страны справляться с кризисом или шоком, таким как дефолт по суверенному долгу или крах фондового рынка.

287 С. 159. Цибулина А.Н. (2014) Банковский и фискальный союзы в ЕС: что важнее? // Вестник МГИМОУниверситета, № 4, с. 159. URL: http://ehd.mgimo.ru/IORManagerMgimo/file?id=8BDAA890-5559-BE7A-5C0B699F05687176.

${ }^{288}$ Mitchel W. (2015) Eurozone Dystopia Groupthink and Denial on a Grand Scale, Cheltenham: Edward Elgar, pp. 94-110. 
Как было в своё время отмечено именитым экономистом Джоном Кейнсом, капиталистическая экономика с децентрализованной рыночной системой не обеспечивает полной занятости и стабильных цен, действуя сама по себе. По его мнению, противоречащему постулатам неоклассической теории занятости, величина и изменение показателей занятости не зависят всецело от поведения работников. Высокие уровни безработицы будут сохраняться, если и правительства, со своей стороны, не прибегнут к настойчивым действиям, чтобы их побороть. Как отмечал Кейнс, когда у людей не хватает денег, чтобы покупать произведенные товары или услуги, цены на них падают, что в принципе помогает привлечь покупателя. Но с падением цен бизнес может начать испытывать существенные потери, выливающиеся в рост числа банкротств. Соответственно растёт и безработица, ещё больше снижающая покупательную способность на потребительском рынке, что опять-таки сказывается в очередном падении цен.

Такой процесс характеризуется как циклический. Чтобы прервать порочный цикл, требуются изменения в фискальной политике, которую проводят государства. Кейнс настаивал в своё время, что правительство способно манипулировать совокупным спросом, чтобы скорректировать нежелательную тенденцию. Значение фискальной политики (политики налогообложения и бюджетных расходов) в качестве средства экономической стабилизации было признано именно под влиянием его трудов ${ }^{289}$. В современных условиях программа экономической стабилизации обычно преследует три цели: (1) контролирование или смягчение циклических колебаний в экономике; (2) содействие экономическому росту; (3) ценовая стабилизация.

Сама по себе архитектура действующего в Европе ЭВС составляет препятствие к проведению дискреционной фискальной политики в целях нейтрализации экономических шоков. Как было показано в первой части настоящей главы, национальная фискальная политика должна проводиться в соответствии с Маастрихтскими критериями и Пактом стабильности и роста. В существующих институциональных условиях вместо того, чтобы использовать национальные бюджеты как инструменты стабилизации, многие правительства стран еврозоны вынуждены при спаде деловой активности, напротив, вести себя проциклически - сокращать расходы или повышать налоги - тем более что им требуется восстанавливать доверие рынка к своей способности обслуживать огромный государственный долг. Для выполнения функций стабилизации и перераспределения особенно важны налогообложение и политика поддержания благосостояния, но для содействия росту куда важнее государственные и особенно частные капиталовложения. Фискальные правила ЕС накладывают ограничения на национальные правительства как раз в тех случаях, когда гибкость нужнее всего 290 .

В отношении дискреционной фискальной политики национального уровня (сознательных шагов по государственному регулированию налогообложения и госрасходов) в Европе многие согласны в том, что из-за неизбежности существенного временного лага она несёт в себе риск правительственных действий, дополнительно усиливающих циклические колебания (проциклических). Дело в том, что изменения в налогообложении и в бюджетных расходах в демократической стране проходят черед длительные процессы принятия решений в парламентах. По политическим причинам их сложно быстро развернуть вспять в случае

\footnotetext{
289 См.: Кейнс Джон Мейнард (2007) общая теория занятости, процента и денег. URL: http://socioline.ru/files/5/316/keyns.pdf.

${ }^{290}$ Alcidi C. and Thirion G. (2016) Assessing the Effect of Shocks in the Euro Area's Shock Absorption Capacity - Risksharing, consumption smoothing and fiscal policies // CEPS Special Report, No. 146, CEPS, Brussels, March. URL: https://www.ceps.eu/system/files/SR146\%20EUBS\%20Assessing\%20the\%20euro\%20area\%E2\%80\%99s\%20shockabsorption\%20capacity.pdf.
} 
более или менее резкого изменения ситуации вследствие экономического шока ${ }^{291}$. К тому же главными целями дискреционной фискальной политики традиционно считаются распределение доходов и аллокация (распределение) ресурсов, а вовсе не экономическая стабилизация.

Если экономическая теория и эмпирические наблюдения в принципе позволяют рекомендовать несколько разных потенциальных функций для наднациональной фискальной политики в хорошо функционирующем валютном союзе, то в зоне евро до настоящего времени отсутствуют, по крайней мере, две из них. Это функция страхования от рисков (предусматривающая временный перевод финансовых ресурсов в те регионы, которые пострадали от асимметричного шока) и общая стабилизационная функция (помогающая гасить симметричные шоки, от которых страдает валютный союз в целом).

Несбалансированная на европейском уровне макроэкономическая политика приводит к тому, что слишком большое бремя по амортизации и компенсации неблагоприятного развития ситуации в европейской экономике переносится на ЕЦБ - в рамках проводимой им наднациональной денежно-кредитной политики. В результате государства-члены, европейский бизнес и граждане не получают в полной мере всех возможных выгод от ЭВС, а ЕЦБ рискует своей репутацией.

Само собой разумеется, что общая кредитно-денежная политика в Евросоюзе не может с равным успехом решать проблемы стран, которые находятся на разных стадиях экономического цикла. Так как страны-участницы лишены возможности адаптироваться к шокам по отдельности, используя номинальный валютный курс, нейтрализацию асимметричных шоков логично был бы обеспечивать на европейском уровне. Для симметричных шоков единой кредитно-денежной политики, по большому счёту, достаточно. Но такая политика становится относительно менее действенной, когда процентные ставки стремятся к нулю, как это и происходило в еврозоне в самом недавнем прошлом (см. график на следующей странице). В подобной ситуации наличие общих средств, предназначенных для финансирования соответствующей экономической функции, снижало бы давление на Европейский центральный банк, побуждающее его в денежно-кредитной политике прибегать к нетрадиционным мерам, которые могут иметь опасные политические издержки. Поэтому вполне логично, что в Докладе пяти председателей 2015 года на запланированном втором (из трёх) этапе углубления Экономического и валютного союза (в 2017-2025 гг.) было предложено, в числе прочего, создать общий функциональный элемент макроэкономической стабилизации. В этом Докладе были изложены и принципы, которым бюджет еврозоны должен был бы быть подчинён, в том числе:

$>$ он не должен был привести к постоянным трансфертам между странами или к трансфертам только в одном направлении и не должен был восприниматься как средство уравнивания доходов между государствами-членами;

$>$ он не должен был подрывать стимулы к проведению взвешенной фискальной политики на национальном уровне

$>$ он должен был сочетаться с существующими в ЕС фискальными рамками и с процедурами по координации курсов национальной экономической политики;

$>$ он не должен был становиться инструментом кризисного управления, поскольку эту функцию уже выполняет Европейский механизм стабильности;

$>$ должен был быть обеспечен демократический контроль над той инстанцией, которая станет распоряжаться этим бюджетом («министр финансов» еврозоны).

\footnotetext{
${ }^{291}$ CM.: Issing Otmar (2005) The role of fiscal and monetary policies in the stabilisation of the economic cycle. Speech at the International Conference "Stability and Economic Growth: The Role of the Central Bank". Mexico City, 14 November. URL: https:/www.ecb.europa.eu/press/key/date/2005/html/sp051114.en.html.
} 
В представлении Комиссии, будущий европейский министр экономики и финансов, если бы такой пост был создан, мог бы получить статус заместителя председателя ЕК и главы Еврогруппы, что, как считают многие эксперты, достижимо и в ныне действующих договорных рамках.

Если говорить о конкретных инструментах экономической стабилизации, то её целям могли бы в принципе служить хорошо известные в Европе из национальной практики автоматические стабилизаторы (automatic stabilizers) - такие инструменты фискальной политики, которые позволяют нарастить бюджетные расходы во время спада экономики или увеличить доходные статьи бюджета в период экономического роста, не требуя при этом принятия правительственного решения в каждом конкретном случае (в качестве примеров автоматических стабилизаторов в специальной литературе чаще всего упоминают пособия по безработице, а также прогрессивный подоходный налог). Короче говоря, автоматическим стабилизатором именуются меры в экономической политике, которые позволяют компенсировать флуктуации (внезапные подъёмы и спады) без специального экстренного государственного вмешательства ${ }^{292}$.

\section{График 4-1 293}

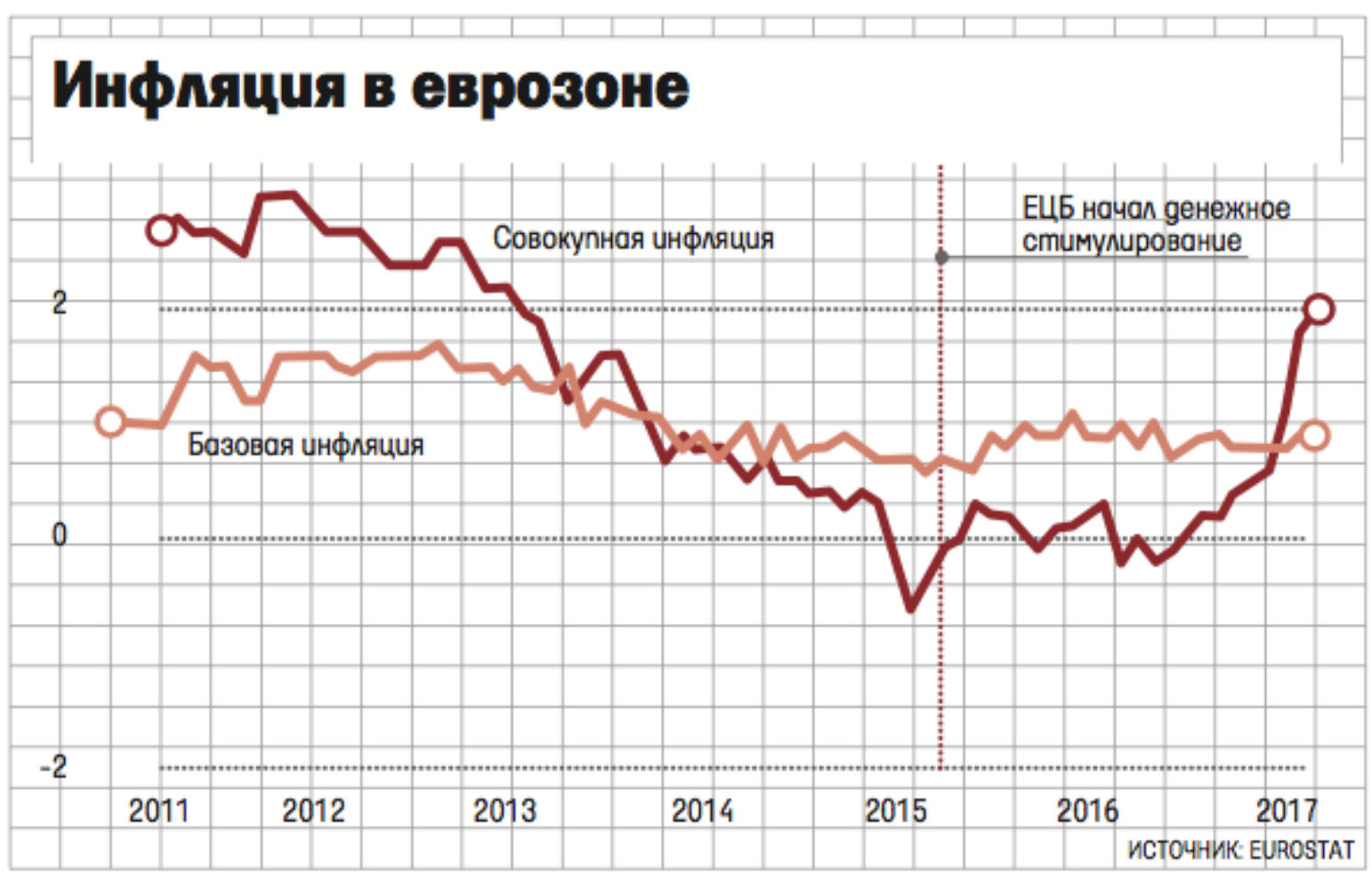

Источник: Ведомости, 02 марта 2017.

Идея оснащения наднационального валютного союза автоматическими стабилизаторами европейского уровня, которые в определённых условиях дополняли бы национальные инструменты автоматической стабилизации, вовсе не нова. Доклад Маржолена

\footnotetext{
${ }^{292}$ In't Veld J., Larch M. and Vandeweyer M. (2012) Automatic Fiscal Stabilisers: What they are and what they do // European Economy Economic Papers, No. 452, European Commission, Directorate General Economic and Financial Affairs (DG ECFIN), Brussels, April.

${ }^{293}$ Ввиду достижения инфляцией целевого значения в 2017 г. на ЕЦБ сильнее начинают давить сторонники ужесточения денежной политики в еврозоне. Цит. по: Хан Мехрин, Джонс Клэр. Инфляция в еврозоне достигла 2\% впервые за четыре года. URL: https:/www.vedomosti.ru/economics/articles/2017/03/02/679723-inflyatsiyaevrozone-2\#galleries\%2F140737493163793\%2Fnormal\%2F 1.
} 
1975 г. ${ }^{294}$ и доклад Макдугалла 1977 г. ${ }^{295}$ отмечали, что создание ЭВС потребует введения европейской схемы пособия по безработице. Прорывной теоретический вклад по вопросу наделения валютного союза общим устройством для фискального страхования был сделан Кененом - учёным, который занимался разработкой теории оптимальных валютных 3 зн $^{296}$.

Сосредоточившись на обсуждении (отсутствовавших в Европе) предпосылок для ОВ3 по Роберту Манделлу, доклад Макдугалла, выпущенный Комиссией ЕЭС, содержал рекомендацию по введению контрциклических фискальных стабилизаторов европейского уровня для борьбы с региональными асимметричными шокам. В 1993 г. Комиссия, кроме того, предложила ввести механизм по демпфированию экономических шоков, ориентированный на изменения в национальных уровнях безработицы, что позволяло бы поддержать государства при решении задач стабилизации делового цикла в еврозоне. Опыт проведения в США политики по поддержке безработных специально изучал в этой связи немецкий экономист Себастьян Даллиен (Sebastian Dullien) ${ }^{297}$.

Рассматриваемые сейчас в ЕС и готовящиеся к возможному внедрению варианты общего для еврозоны автоматического стабилизатора (они были, к примеру, проанализированы в аналитическом докладе Комиссии об углублении Экономического и валютного союза ${ }^{298}$ ) включают как минимум три возможных варианта:

Европейскую схему страхования от безработицы (т.е. воспроизведение действия национальных пособий по безработице на европейском уровне, вторичную страховку по безработице на «верхнем этаже» европейского здания). В системах социального страхования в «тучные времена» обычно возникает избыток средств, когда платежи, поступающие от работников, превышают расходы на безработных, но в кризисный период можно, естественно, увидеть обратную картину. Задумка такова, что в ситуации асимметричного шока в европейской схеме по страхованию от безработицы аккумулировались бы средства из стран, находящихся в более благополучном экономическом состоянии, которые расходовались бы на покрытие соответствующего дефицита в странах, испытывающих рецессию. Если бы подобная схема действовала в дополнение к национальным системам, покрывая только циклические колебания в сфере занятости, можно было бы надеяться, что она не погасит мотивацию национальных правительств к самостоятельному проведению ими мер по сокращению структурной безработицы. В 2013 г. Комиссия и несколько европейских правительств в очередной раз предложили осуществление европейской схемы пособия по безработице, которая способствовала бы стабилизации экономик, поражённых асимметричными шоками. В частности, согласно предложениям Даллиена, трансферты следовало бы ограничивать периодом максимум в один год, а индивидуальные получатели таких средств должны были бы быть застрахованы в системе минимум за несколько месяцев до потери работы.

\footnotetext{
${ }^{294}$ Marjolin, R., F. Bobba, H. Bosman, G. Brouwers, L. Camu, B. Clappier, I. Foighel, F. Forte, H. Giersch, P. Lynch, D. MacDougall, H. Markmann, F. Peeters, A. Shonfield and N. Thysegen (1975) Report of the Study Group 'Economic and Monetary Union 1980', European Commission, Brussels.

${ }^{295}$ Commission of the European Communities, Report of the Study Group on the Role of Public Finance in European Integration, Volume I, Brussels, April 1977. URL: https:/www.cvce.eu/content/publication/2012/5/31/c475e949-ed28490b-81ae-a33ce9860d09/publishable_en.pdf; Commission of the European Communities, Report of the Study Group on the Role of Public Finance in European Integration, Volume II, Brussels, April 1977. URL: https://www.cvce.eu/content/publication/2012/5/31/91882415-8b25-4f01-b18c-4b6123a597f3/publishable_en.pdf.

${ }^{296}$ Kenen P. (1969) The Theory of Optimum Currency Areas: An Eclectic View // Monetary Problems of the International Economy, / R. Mundell and A. Swoboda (eds), Chicago, IL: University of Chicago Press, 41-60.

${ }^{297}$ Dullien S. (2014) The Macroeconomic Stabilisation Impact of a European Basic Unemployment Insurance Scheme // Intereconomics, vol. 49 (4), pp. 189-193.

298 Reflection Paper on the Deepening of the Economic and Monetary Union. May 2017. URL: https://ec.europa.eu/commission/sites/beta-political/files/reflection-paper-emu_en.pdf.
} 
Фонд «на чёрный день». Это упрощённый стабилизационный фонд, который осуществлял бы автоматические поддерживающие выплаты государствам-членам, испытывающим экономические трудности. Он мог бы финансироваться на основании ежегодных национальных взносов либо вкладов, осуществляемых только в «тучные времена». Итальянское правительство, например, в таком русле выступает за создание в рамках ЭВС фонда для непредвиденных расходов (rainy-day fund) на цели поддержки безработных, дополненного программой по защите инвестиций, стимулирующих экономический рост ${ }^{299}$.

Общий инвестищионный фонд (в особенности для инвестиций в инфраструктуру или повышение квалификации работников). Такой инструмент был бы более полезен в приложении к симметричным шокам, позволяя наращивать объёмы капиталовложений в то время, когда в ЕС резко падают частные инвестиции. Он мог бы взять на себя финансирование крупных, общеевропейских инвестиционных проектов, в сферах энергетики, цифровизации экономики и транспорта.

Европейская комиссия на этот раз выделила три ключевых черты, которым должна соответствовать функция стабилизации, призванная содействовать укреплению ЭВС ${ }^{300}$ :

(1) она должна опираться на механизм, действующий автоматически; (2) она не должна предполагать постоянных трансфертов или вести к постоянным однонаправленным трансфертам от одних стран к другим; (3) она должна исключать риск недобросовестного поведения, чтобы не подрывать стимулов к проведению государствами осмотрительной бюджетной политики и структурных реформ.

В нынешних политических условиях полнокровный бюджет федерального уровня в ЕС остаётся политически не достижимым. Вышеперечисленное - это ограниченные варианты, предполагающие частичные решения. Более радикальных изменений в плане развития у ЕС функций по стабилизации экономики по-прежнему вряд ли следует ожидать в реальности.

Автоматический характер действия подобного рода инструментов считается в ЕС исключительно важным для обеспечения их действенности преимуществом. В отсутствие автоматизма в распределении денег временной лаг между возникновением шока и реакцией на него может сильно возрасти, подрывая надёжность искомой стабилизации. Поэтому политических дискуссий и длительных процедур принятия решений здесь желательно избегать, заранее оговорив все условия и не оставляя места для двойных стандартов и политизации. Помимо прочего, автоматические стабилизаторы европейского уровня обещают снизить потребность национальных правительств в мерах дискреционной макроэкономической политики для противостояния специфичным для данной страны экономическим потрясениям.

Заметно более амбициозным, нежели только что перечисленные варианты, явилось предложение президента Франции Эммануэля Макрона о создании бюджета специально для еврозоны на основании вкладов/налогов от государств-членов. Средства из него расходовались бы на совместные инвестиционные проекты, направленные не только на макроэкономическую стабилизацию, но и на сближение параметров национальных экономик ${ }^{301}$.

Как и в Европейском союзе, отдельные регионы в федеративном государстве тоже лишены важных инструментов макроэкономического управления и могут пострадать от негативных последствий единообразной денежно-кредитной политики, которая не учитывает

\footnotetext{
299 Italian Ministry of Finance (2017) Italian Contribution on Deepening the EMU. Rome. URL: http://www.mef.gov.it/inevidenza/documenti/Proposal_CL_23_May.pdf.

${ }^{300}$ European Commission (2012) Blueprint for a deep and genuine Economic Monetary Union, COM(2012) 777 final/2.

${ }^{301}$ Macron Emmanuel (2017) Initiative pour l'Europe - Discours d'Emmanuel Macron pour une Europe souveraine, unie, démocratique. Publié le 26 Septembre 2017. Speech at the Sorbonne, Paris, September 26. URL : http://www.elysee.fr/declarations/article/initiative-pour-1-europe-discours-d-emmanuel-macron-pour-une-europesouveraine-unie-democratique/
} 
региональную специфику. Однако у центрального правительства в условиях федерации есть достаточно большой бюджет. Его доходы основаны на налогах, которые влияют на хозяйственную активность, а его расходы могут включать программы, реагирующие на экономические подъёмы и спады. Национальная система налогообложения и национальные расходы по линии социальной политики в рамках федерации, как показывает в том числе и релевантный европейский национальный опыт, способны сглаживать различия между субъектами. В противоположность этому, в ЕС нет центрального (федерального) правительства, a государствам-членам предлагается справляться с возникающими экономическими проблемами, главным образом, собственными силами.

Вместе с тем у идеи наделения еврозоны собственными финансовыми средствами по автоматической нейтрализации экономических шоков имеются и серьёзные противники. Они указывают на то, что даже в известных системах бюджетного федерализма, при уровнях централизации, политически не достижимых для еврозоны в обозримой перспективе, стабилизирующее воздействие фискальной политики оказывается ограниченным ${ }^{302}$. Помимо этого, внедрение автоматических стабилизаторов в рамках ЭВС может иметь и нежелательные (по крайней мере, с точки зрения некоторых стран еврозоны) последствия.

При обсуждении в кругу специалистов дальнейшей фискальной интеграции в еврозоне в ходу два понятия - фискальный союз и трансферный союз 303 , разницу между которыми полезно принять во внимание. В термин «фискальный союз» в специальной литературе у разных авторов вкладывается различное содержание - от набора общих фискальных правил, которые должны соблюдать национальные правительства, до оформления в подлинном смысле федерального правительства европейского уровня, имеющего власть устанавливать налоги и расходовать общий бюджет ${ }^{304}$.

Так, относительно более широкое определение фискального союза даёт Марек Дабровский, для которого он означает передачу части бюджетно-налоговых ресурсов и компетенций в области фискальной политики, а также распоряжение бюджетом с национального на наднациональный уровень ${ }^{305}$. Иначе говоря, в широком плане фискальную интеграцию следует, скорее, воспринимать как совокупность усилий по дальнейшей централизации бюджетно-налоговой политики в ЭВС, будь то средствами коллективного использования ресурсов или наделения наднационального уровня власти новыми полномочиями. В таком смысле она может включать целый набор инструментов, направленных как на снижение рисков, так и на амортизацию шоков (см. рисунок 4-1). В более узком смысле разговор о фискальном союзе в ЕС сейчас ограничивается обсуждением возможностей наделения его общими бюджетными средствами (common fiscal capacity). Если исходить из того, что строительство Банковского союза всё же удастся успешно завершить, можно предполагать дальнейшую фискальную интеграцию, которая пойдёт по одному из двух возможных путей: наращивание сферы общего суверенитета (жёсткая координация национальных курсов при гибридных формах управления, включающих наднациональные

\footnotetext{
${ }^{302}$ Feld Lars and Osterloh Steffen (2013) Is a fiscal capacity really necessary to complete EMU? Paper presented at the workshop "How to build a genuine Economic and Monetary Union". URL: https://www.sachverstaendigenratwirtschaft.de/fileadmin/dateiablage/Sonstiges/Genshagen_Paper___Feld.pdf.

${ }^{303}$ Смирнов Е. Н. (2014) Риски развития современной экономики Европейского союза как отражение кризиса национальных моделей социально-экономического развития // Интернет-журнал «Науковедение», выпуск 6 (25), ноябрь-декабрь. URL: https://naukovedenie.ru/PDF/160EVN614.pdf.

${ }^{304}$ Kąkol M. (2017) Designing a fiscal union for the euro area // Ekonomia i Prawo. Ecomomics and Law, vol. 16, issue 4, pp. 413-432. URL:

https://www.researchgate.net/publication/322815877_Designing_a_fiscal_union_for_the_euro_areahttps://www.researc hgate.net/publication/322815877_Designing_a_fiscal_union_for_the_euro_area.

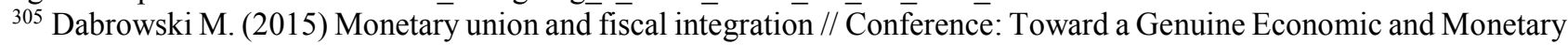
Union. At: Vienna. Volume: Workshop - Proceedings of the OeNB Workshops, No. 21. URL: https://www.researchgate.net/publication/299435966_Monetary_union_and_fiscal_integration.
} 
элементы) или развитие форм разделения рисков - вплоть до выпуска евробондов от лица еврозоны в целом.

Непосредственной целью трансферного союза, в свою очередь, является только сокращение разрыва в доходах между странами. Оно может достигаться систематическим и долговременным перераспределением доходов между ними в пользу «нуждающихся», что не устраивает страны-«доноры», в первую очередь Германию, для которой приоритетом выступает «союз стабильности» с централизацией управления национальными бюджетами, о чём уже шла речь выше и что больше соответствует развитию фискальной интеграции по первому пути. В русле подобного подхода версию дальнейшей интенсификации макроэкономической координации предложили ещё в 2011 г. немецкий политики Вольфганг Шойбле (Wolfgang Schaeuble) и бывший глава ЕЦБ Жан-Клод Трише ${ }^{306}$. Они выступили за учреждение поста европейского министра финансов в роли своеобразного наднационального надзирателя, т.е. наделённого правом вето в отношении проектов бюджета государств-членов. Не исключалось и жёсткое принуждение государств к выполнению европейских рекомендаций по национальному бюджету.
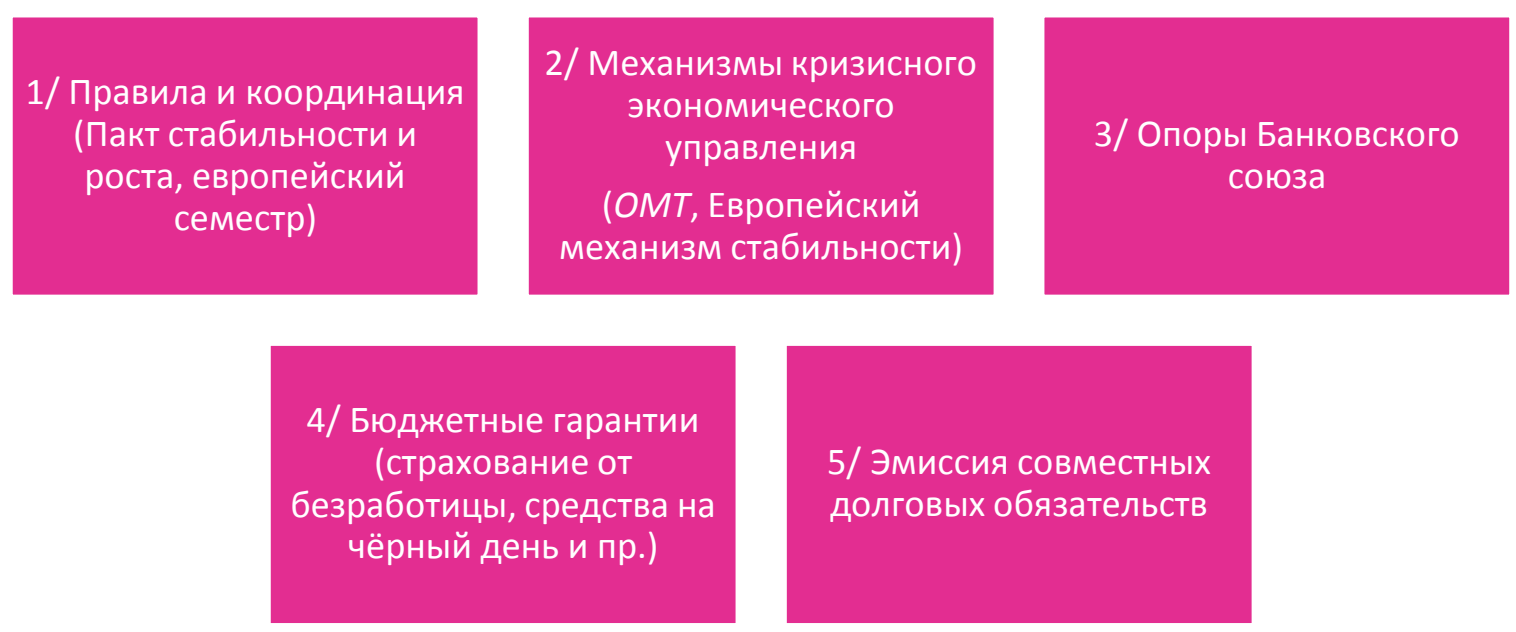

Рисунок 4-1. Компоненть фискального союза

В отличие от трансферного союза, «узкий» фискальный союз по направлению разделения рисков создаётся, чтобы некими бюджетными средствами смягчить колебания в доходах во времени и между странами (т.е. он не предполагает отладки фискальными средствами экономического цикла в пределах еврозоны), а потому выглядит политически более или менее приемлемым, достижимым, в том числе даже для Германии. В последнем случае трансферты обещают быть временными, но не систематическими.

Однако степень, в которой на практике может происходить размывание грани между фискальным союзом и трансферным союзом, по большому счёту, зависит от того, как конкретно устроены автоматические стабилизаторы, что повышает политическую значимость детального обсуждения данного вопроса. При этом заранее гарантировать, что в любом случае непрекращающиеся трансферты между странами еврозоны будут стопроцентно исключены, по сути невозможно. Отметим, что введение некоего европейского стабилизационного

\footnotetext{
${ }^{306}$ Vits C., and G. Thesing (2011) Trichet Calls for Euro Finance Ministry as Crisis Deepens // Bloomberg Business, 2 June.
} 
механизма, при всех сомнениях ряда экономистов в его разумности, явилось бы в то же время мощным средством по преодолению усугубившегося кризиса легитимности в ЕС, серьёзно угрожающего перспективам развития интеграционного объединения.

Споры вокруг идеи специального бюджета для еврозоны, для которого важно изыскать какие-то специфические стабильные источники дохода, продолжаются. Комиссия ЕС летом 2017 г. опубликовала аналитический доклад о будущем европейских финансов ${ }^{307}$, за страницами которого стоял именно данный, острейший для Евросоюза, политический вопрос: должен ли у еврозоны быть собственный бюджет, отдельный от бюджета всего ЕС? Значимость и острота этого вопроса усугубились в момент, когда Европейский союз готовится расстаться с одним из своих крупнейших членов (Великобританией, не участвовавшей в зоне евро), что отразится и в сокращении общего бюджета объединения. По завершении Брексита на долю еврозоны будет приходиться уже $85 \%$ совокупного ВВП Евросоюза и $76 \%$ его населения. В подобных условиях на самом деле создание для еврозоны дополнительного отдельного бюджета теперь выглядит менее оправданным, чем раньше. Великобритания вносила в бюджет ЕС второй по величине вклад после Германии. Все понимают, что Брексит отразится на доходной части бюджета ЕС, заставляя переосмысливать его роль в европейском экономическом управлении на будущее.

В настоящее время Комиссия склоняется к заключению, что в будущем функцию макроэкономической стабилизации должен выполнять существующий бюджет ЕС, т.е. создавать специальный бюджет для еврозоны не планируется. В мае 2018 г. ЕК представила свои предложения по многолетним финансовым рамкам для ЕС на период 2021-2027 гг. при общем объёме запланированных средств в 1135 млрд. евро, что, конечно, не означает общего наращивания европейского бюджета. Тем не менее, предложения Европейской комиссии касательно многолетних финансовых рамок включают положения по созданию Европейского инвестиционного блока стабилизационного назначения (European Investment Stabilisation Function, EISF) объёмом до 30 млрд. евро. С его помощью, по соображениям ЕК, можно было бы гарантировать выпуск компенсационных займов на поддержку испытывающих трудности национальных экономик, чтобы поддерживать таким образом уровни инвестирования в национальных рамках ${ }^{308}$. В Комиссии высказывают надежду, что предусмотренная в бюджете стабилизационная функция (основанная на займах и бюджетной поддержке), возникнув таким образом, укреплялась бы со временем.

Подобный инструмент, по мысли Комиссии, мог бы использоваться при менее значительных асимметричных шоках, тогда как для противостояния серьёзным финансовым потрясениям, угрожающим Союзу в целом, уже был основан Европейский механизм стабильности. По форме предлагаемый инвестиционный блок мог бы стать схемой по поддержке инвестиций, страхованием от безработицы или резервным «фондом на чёрный день», уже упомянутыми. Но актуальное предложение Комиссии было раскритиковано главой Европейской фискальной палаты Нильсом Тигесеном как слишком скромное, мелкое и недостаточно продуманное 309 .

Действительно, согласно теории оптимальной валютной зоны, минимизировать затраты, связанные с отказом государств от национальной валюты, можно, не только имея гибкие заработные платы и цены, а также высокую мобильность рабочей силы, но и через централизацию бюджетных расходов. Решить такую проблему в принципе допустимо, опираясь на наднациональный европейский бюджет. В идеале, консолидировав

\footnotetext{
307 European Commission (2017) Reflection Paper on the Future of EU Finances. URL: $\mathrm{https} / /$ ec.europa.eu/commission/sites/beta-political/files/reflection-paper-eu-finances_en.pdf. ${ }^{308}$ European Commission (2017) New Budgetary Instruments for a Stable Euro Area within the Union Framework. Brussels. URL: https://ec.europa.eu/commission/sites/beta-political/files/budgetary-instruments-euro-area_en.pdf.

${ }^{309}$ URL: https://www.euractiv.com/section/economy-jobs/news/commissions-stabilisation-function-very-modest-sayseurozone-fiscal-sheriff/
} 
(сосредоточив) национальные бюджеты на европейском уровне, можно было бы организовать механизм автоматических денежных трансфертов между странами. Такой страховочный механизм позволял бы перебрасывать необходимые ресурсы в ту страну, которая в наибольшей степени подверглась негативным экономическим шокам. Но бюджет ЕС относительно мал, составляя около 1\% совокупного ВВП его государства-членов, хотя в годы экономического и финансового кризиса было подтверждено, что европейский бюджет является инструментом по поддержанию инвестиционного процесса, влияние которого тоже не стоит игнорировать.

Если же достаточный по объёму централизованный бюджет отсутствует, а ощутимые по мощности автоматические стабилизаторы наднационального уровня включить тоже не удастся, то теория ОВ3 в принципе рекомендует большую гибкость и автономию в национальной фискальной политике стран еврозоны, нежели те, что допускаются ныне Пактом стабильности и европейской практикой. ПСР в его нынешней форме мешает применению автоматических стабилизаторов на национальном уровне. Он препятствует тому, чтобы страны, где дефицит госбюджета близок к допускаемому максимуму в 3\%, наращивали свои контрциклические дефициты в периоды экономического спада. В области координации национальной бюджетной политики в ЕС работает жёсткий (интрузивный) механизм, который опирается на нормы, подлежащие точному соблюдению национальными правительствами, а также на возможность введения чувствительных санкций в случае нарушения принятых на европейском уровне ограничений. Между тем, как предупреждают многие специалисты, в особенности те из них, кто привержен кейнсианской школе и неокейнсианству, правило сбалансированного национального бюджета, сколь бы оно ни казалось разумным, в некоторых случаях может принести и негативные последствия.

Ещё недавно в тех обсуждениях, которые продолжаются вестись вокруг перспектив изменения рамок управления бюджетно-налоговой политикой в еврозоне, как и учреждения дополнительных инструментов распределения между странами циклических рисков, возможная роль существующего наднационального бюджета Европейского союза не привлекала к себе пристального внимания специалистов. Но на самом деле в сложившихся обстоятельствах это пока единственный реально работающий «общий» инструмент экономической стабилизации в ЕС, хотя он является в данном случае инструментом непрямого действия и ограничен по масштабу.

Уточним, что в целом действие наднационального бюджета Европейского союза направлено главным образом на цели перераспределения ресурсов между государствамичленами и обеспечивает усилия по конвергенции их экономики, как и прямое предоставление общественных благ. Объём бюджета ЕС составляет порядка полутора сотен миллиардов евро в год, что придаёт ему известную значимость с макроэкономической точки зрения. В то же время такой объём общего бюджета решительно не соответствует целям построения на базе Евросоюза «традиционной» федерации, в которой одной из задач центрального правительства, помимо перераспределения, выступает именно экономическая стабилизация - наряду с имеющимися у него полномочиями по принятию решений о дефицитном финансировании.

В принципе бюджет ЕС нацелен на то, чтобы сделать экономику интегрированной Европы, под которой в данном случае понимаются скорее национальные экономики всех его государств-членов, более сильной и устойчивой во всеобъемлющем смысле. Он призван повысить их способность поглощать удары, укрепив потенциал экономического роста и приблизив ВВП на душу населения в относительно бедных странах к уровню аналогичного показателя в самых богатых странах ЕС. О некотором (весьма ограниченном) намеренном перераспределении средств между богатыми и бедными странами через европейский бюджет 
имеет смысл говорить применительно к региональной политике ${ }^{310}$ и политике сплочения ${ }^{311}$. Политика сплочения и региональная политика в ЕС решают задачи по сокращению существенных экономических и социальных различий между государствами-членами или их регионами. На такие цели, скажем, на период 2014-2020 годов в рамках многолетней финансовой перспективы было выделено около одной трети (351,8 млрд. евро) общего бюджета $\mathrm{EC}^{312}$.

Финансовыми инструментами политики сплочения выступают, прежде всего, два структурных фонда (помимо Фонда регионального развития, это Европейский социальный фонд), а также Фонд сплочения (в некоторых государствах-членах, в особенности тех, что вступили в ЕС в 2004-2007 гг. - он поддерживает модернизацию инфраструктуры, зачастую являясь единственным источником средств на подобные цели), Европейский аграрный фонд для целей сельского развития и Европейский морской и рыболовный фонд. Общая сельскохозяйственная политика (её расходы на 2014-2020 гг. были определены в 420 млрд. евро), со своей стороны, поддерживает независимый (в плане продовольственного обеспечения) сельскохозяйственный сектор в Евросоюзе.

Политика сплочения (480 млрд. евро на тот же период с учётом национального софинансирования, см. диаграмму 4-1) предполагает существенные трансферты (перераспределение) от одних стран к другим. Основными получателями этих средств выступают самые небогатые регионы в ЕС - в особенности из стран Центральной и Восточной Европы (на их долю приходится около 70\% соответствующих фондов), а также из некоторых стран европейской периферии.

Чистая сумма трансфертов от богатых стран ЕС к бедным составляет до 4\% ВНД странполучательниц, к числу которых относятся и страны, получавшие экстренную международную финансовую помощь (Греция, Ирландия, Испания, Кипр и Португалия). В некоторых государствах-членах структурные фонды (Европейский фонд регионального развития и Европейский социальный фонд) являются главным источником финансирования государственных капиталовложений. Но фактические данные показывают, что с 1999 г. устойчивого сближения в экономических показателях стран, первыми вступивших в еврозону, тем не менее, не произошло, даже напротив: в период кризиса ситуация в этом плане ухудшилась.

Бюджет ЕС принимается ежегодно на основании согласия, достигаемого Советом министров и Европейским парламентом. Он должен укладываться в максимальные лимиты расходов по различным статьям, установленные в многолетних финансовых рамках ЕС. Эти рамки, отражающие иерархию политических приоритетов на весь заданный период планирования, единогласно принимает Совет на основании предложения Комиссии. Распределение по источникам доходов европейского бюджета не только устанавливается единогласно всеми государствами-членами ЕC, но и подлежит ратификации в национальных парламентах.

В дополнение к выполнению своих основных задач, бюджет ЕС - хотя центрального правительства в объединении не существует - действует как (относительно слабый) автоматический стабилизатор наднационального уровня. Такое его действие включается при

\footnotetext{
${ }^{310}$ Региональная политика - это инвестиционная политика, которая преследует цель уменьшения разрыва между различными районами ЕС и преодоления отсталости районов, находящихся в наименее благоприятных условиях. ${ }^{311}$ Политика сплочения в ЕС подразумевает стратегию сбалансированного и устойчивого экономического, социального и территориального развития. Это более широкое понятие, нежели региональная политика, которая привязана главным образом к Европейскому фонду регионального развития (ЕФРР) и действует исключительно на уровне субнациональных регионов.

${ }^{312}$ Для сравнения: ВВП Евросоюза составляет около 13 трлн. евро в год. Фонды на цели сплочения составляют, таким образом, примерно 0,39\% от совокупного ВВП Евросоюза на семилетний период. До 2004 г. на долю Греции приходилась сумма из евробюджета, равная 4\% национального ВВП (наивысший показатель).
} 
асимметричных шоках, так как национальные вклады в европейский бюджет могут сокращаться (если рост ВНП страны падает относительно роста в ЕС в целом), а поступления из европейского бюджета для соответствующих стран при этом не изменяются в объёме.

Бюджет ЕС в его сложившихся формах часто подвергается критике как исторический рудимент, плохо совместимый с актуальным состоянием и перспективами европейской интеграции ${ }^{313}$. Однако он демонстрирует особую стойкость к изменениям. Экономические функции, которые он выполняет, остаются ограниченными и служат предметом для бурных политических и научных споров. Так, на уровне государств-членов или субнациональных регионов выделяют и подчёркивают его (пере)распределительную роль ${ }^{314}$. Но в европейских институтах имеющийся наднациональный бюджет считают скорее аллокативным.

Диаграмма 4-1

Доля финансирования по линии политики сплочения (с учётом национального софинансирования) в общем объёме государственных и европейских бюджетных инвестиичий в пиковый период кризиса (2010-2012 г2.) в отдельных странах EC (в проиентах)

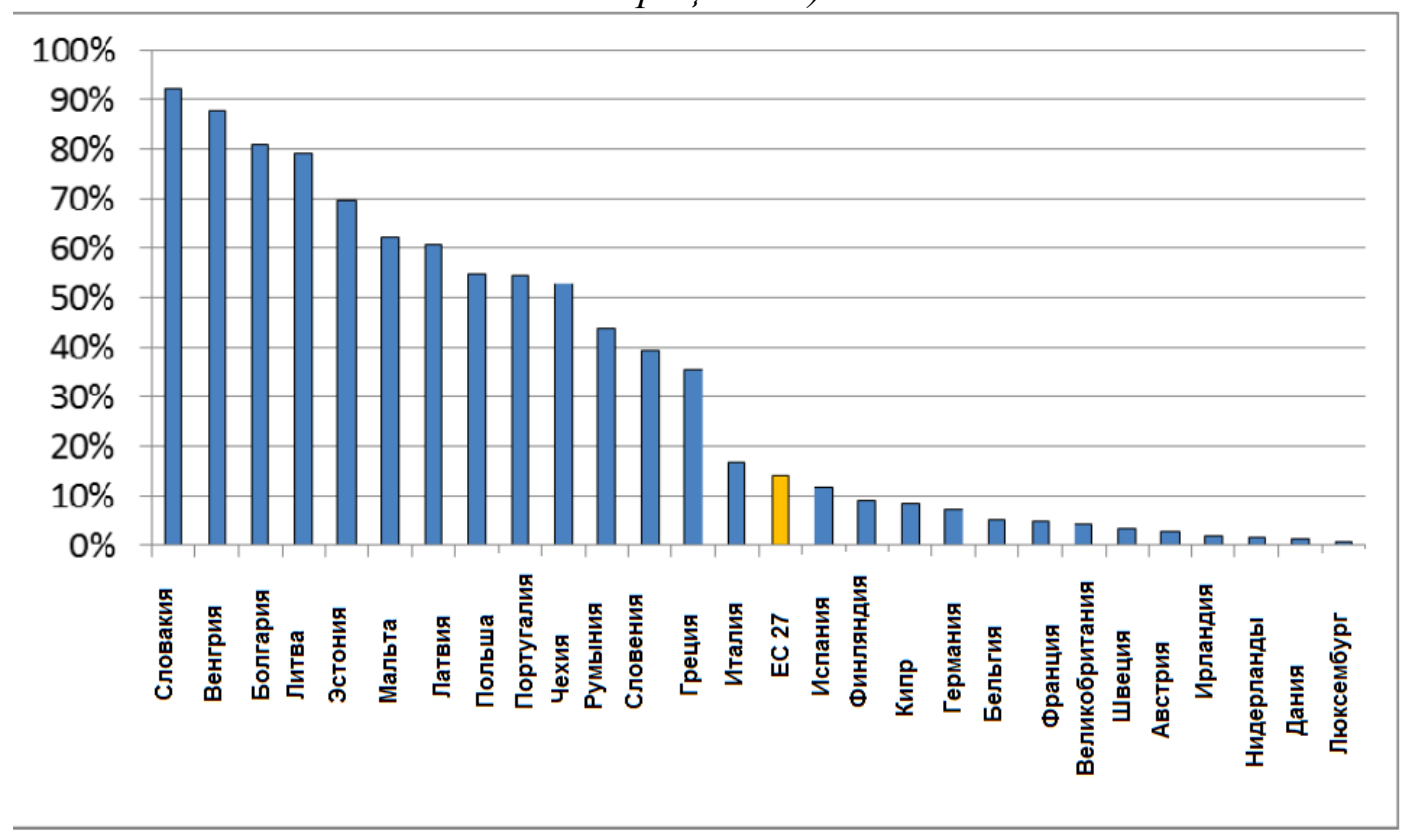

Источник: European Commission (2013), Cohesion Policy Report, http://ec.europa.eu/regional_policy/sources/how/policy/doc/strategic_report/2013/strat_report_2013_en.pdf

Однако первоначально бюджет западноевропейского интеграционного объединения получил развитие в качестве отраслевой поддержки для сельского хозяйства и как инвестиционный инструмент субнационального уровня применения. По большому счёту, он и сейчас мало годится для того, чтобы быстро и адекватно реагировать с его помощью на экономические шоки или реализовывать меры по противодействию циклическим колебаниям в экономике еврозоны. Бюджету ЕС свойственны серьёзные структурные слабости: он не только относительно невелик, но и имеет жёсткую архитектуру. Ныне действующая его система основана на принципах среднесрочного планирования, которую чрезвычайно трудно

\footnotetext{
${ }^{313}$ Buti M. and Franco D. (2005) Fiscal policy in economic and monetary union: theory, evidence and Institutions, Cheltenham/UK and Northampton/MA/USA: Edward Elgar.

314 Tabellini, G. (2003) Principles of policymaking in the European Union: an economic perspective // CESifo Economic Studies, volume 49, issue 1, 1 January pp. 75-102.
} 
было бы серьёзно реформировать. Возможности для быстрой переброски средств с одной позиции на другую такая ригидная система не предоставляет. В то же время отметим, что расходы европейского бюджета сосредоточены на определённых сферах деятельности и на конкретных регионах, где их масштаб порой вполне позволяет стабилизировать уровни государственного финансирования в конкретных странах, о чём может свидетельствовать нижеприведенная диаграмма.

Вне непосредственных рамок бюджета EC, но гарантированная его неизрасходованными средствами вплоть до потолка в $1.23 \%$ ВНД, возможна помощь отдельным странам в экстренных случаях: например, на поддержание платёжного баланса (Balance of Payments $\{$ BoP $\}$ assistance) - для не входящих в еврозону стран ЕС. Наконец, Фонд солидарности Европейского союза (Solidarity Fund of the European Union) тоже может предоставлять ограниченную финансовую помощь государствам-членам, пострадавшим от серьёзных природных катастроф, а Европейский фонд адаптации к условиям глобализации (European Globalisation Adjustment Fund) - оказывать единовременное содействие работникам при неожиданном увольнении, связанном с изменениями в условиях глобальной торговли или с дезорганизацией в экономике.

Bсе перечисленные здесь, относительно скромные по своим возможностям, финансовые инструменты сочетают цели достижения финансовой стабильности и циклической стабилизации экономики, но действуют только в исключительных случаях, а не постоянно или автоматически. Они также мало подходят для противодействия кризису, длящемуся достаточно длительный период времени.

В принципе инструменту экономической стабилизации в еврозоне требуются автоматический триггер (активатор), возможность быстрого перечисления средств и меняющийся состав получателей - т.е. постоянно действующие передаточные механизмы, которыми европейский бюджет в настоящее время не оснащён. Предусмотренные в нём на цели стабилизации средства в основном не входят в многолетние финансовые рамки ЕС и не доступны напрямую. Для получения соответствующих средств всякий раз требуется отдельная заявка. Подобная ситуация есть следствие того факта, что изначально функция экономической стабилизации на европейском уровне не предусматривалась. Она возникла практически спонтанно из-за угроз и неотложных проблем, вызванных финансовым и экономическим кризисом и его последствиями.

Появление в ЕС более мощных инструментов стабилизации будет во многом зависеть от того, удастся ли превратить Европейский механизм стабильности в Европейский валютный фонд, а также от удачного завершения строительства Банковского союза. Важной целью для ЕС является создание Союза рынков капитала (Capital Markets Union), т.е. преобразование 27 национальных рынков капитала в один интегрированный рынок ${ }^{315}$. Его планируется ввести в действие к 2019 г. ${ }^{316}$.

В США рынки капитала способны абсорбировать до 40\% асимметричных шоков, тогда как в еврозоне такая способность составляет лишь 6\%. Одним из ключевых элементов в планах по реализации европейского СРК выступает решение задачи добиться снижения привязанности частных инвесторов в Европе к «своему» национальному рынку. Это уменьшило бы потребность для национальных правительств в совместном несении рисков, которое обеспечивается учреждением новых фискальных инструментов ${ }^{317}$.

\footnotetext{
${ }^{315} \mathrm{Cm}$. Beer Ch. and Waschiczek W. (2018) Capital markets union: a more diverse financial landscape in the EU? // Monetary Policy \& the Economy, Oesterreichische Nationalbank (Austrian Central Bank), issue Q2/18, pp. 71-86. URL: https://ideas.repec.org/a/onb/oenbmp/y2018iq2-18b4.html.

${ }^{316}$ Цибулина Анна (2015) Союз рынков капитала: еще один союз в ЕC // Bся Eвропа, №11(104). URL: http://alleuropalux.org/?p=12373.

${ }^{317}$ Constâncio V. (2017) Effectivenes of Monetary Union and the Capital Market Union // Speech at the EUROFI Conference, Malta, 6 April. URL: https://www.ecb.europa.eu/press/key/date/2017/html/sp170406_2.en.html.
} 


\section{Инвестиционный план Юнкера}

Меры по фискальной консолидации в странах Евросоюза привели к нежелательным последствиям от снижения государственных расходов. Соответственно, предметом особой озабоченности для правящих кругов в ЕС стало падение инвестиций в инфраструктуру (с 2009 по 2016 гг. они сократились на четверть). Обнаружение наиболее уязвимых мест и отклонений от заявленной нормы внутри отдельных стран и между странами лежит в основе средств мониторинга по европейскому семестру. Но не менее важна способность нейтрализовать экономические шоки и затем восстановить экономику как можно быстрее. Наибольшая доля ответственности в данном смысле лежит на государствах-членах.

Успешное завершение строительства Банковского союза и Союза рынков капитала существенно улучшило бы ситуацию в том, что касается трансграничного распределения рисков в частном секторе ${ }^{318}$. В то же время в любом случае решение этих задач потребует времени, причём даже в долговременной перспективе трансграничные частные финансовые потоки, вероятно, будут оставаться проциклическими и станут разворачиваться вспять в кризисные периоды, как это и наблюдалось в 2008-2009 и в 2011-2012 гг. Поэтому Банковский союз и Союз рынков капитала как таковые не отменяют преимуществ распределения рисков средствами финансово-бюджетными средствами, используемыми, чтобы поддержать совокупный спрос в еврозоне в те моменты, когда возможности ЕЦБ по линии денежнокредитной политики ограничены ${ }^{319}$.

Помимо планов на будущее, в решении стабилизационной задачи глава Европейской комиссии Жак-Клод Юнкер сделал ставку на инвестиционный пакет общим объёмом в 315 млрд. евро ${ }^{320}$, который в 2014 г. был одним из основных пунктов его предвыборной программы как кандидата на этот пост от Европейской народной партии. Если бюджет для еврозоны пока не создан и стабилизационная функция бюджета Европейского союза не отработана на деле, а потому возможности для автоматической стабилизации экономики для нуждающихся в этом стран еврозоны, на наднациональном уровне, по большому счёту, отсутствуют, то этот инвестиционный пакет (впервые в практике Экономического и валютного союза) дал в руки Комиссии инструмент по выправлению ситуации вручную ${ }^{321}$.

Чтобы повысить низкий уровень инвестиций в ЕС, был создан и осенью 2015 г. начал свою работу Европейский фонд стратегических инвестиций (ЕФСИ - European Fund for Strategic Investments, EFSI), которые в 2015-2017 гг. должны были быть направлены в реальную экономику. Гарантийный фонд объёмом в 16 млрд. евро на основании 8 млрд. из бюджета ЕС (50\%-ная гарантия) и 5 млрд. из средств Европейского инвестиционного банка (ЕИБ) послужили в качестве его стартового капитала. Исходные средства могли бы быть и более масштабными, но сопротивление стран Южной и Восточной Европы помешало

\footnotetext{
318 Впрочем, некоторые авторы полагают, что в рамках ЭВС распределение рисков через финансовые рынки в принципе имеет ограниченные масштабы. См.: Furceri D and Zdzienicka A. (2015) The Euro area crisis: Need for a supranational fiscal risk sharing mechanism? // Open Economies Review, 26: pp. 683-710.

${ }^{319}$ Berger Helge, Dell'Ariccia Giovanni, and Obstfeld Maurice (2018) Revisiting the economic case for a fiscal union in the Euro area, Washington, DC: International Monetary Fund, February 20. URL: ttps://www.imf.org/en/Publications/Departmental-Papers-Policy-Papers/Issues/2018/02/20/Revisiting-the-EconomicCase-for-Fiscal-Union-in-the-Euro-Area-45611. Некоторые авторы, напротив, полагают, что достаточно сильный Банковский союз и механизм реструктуризации суверенного долга составляют предпочтительную инициативу углублению фискальной интеграции. См.: Eichengreen Barry (2018) The Populist Temptation. Economic Grievance and Political Reaction in the Modern Era, Oxford: Oxford University Press. Регионализацию фискальной политики в ЕС Айхенгрин считает важной для обуздания волны европейского популизма.

${ }^{320}$ Для сравнения: бюджет ЕС на 2019 г. составляет 166 млрд. евро.

${ }^{321}$ Schneider J.D. (2015) Growth for Europe - is the Juncker Plan the Answer? // European Policy Centre Discussion Paper, March. URL: http://www.epc.eu/documents/uploads/pub_5420_growth_for_europe_is_the_juncker_plan_the_answer.pdf.
} 
перебросить на эти цели деньги из фондов сплочения, хотя значительная их часть в настоящее время остаётся неизрасходованной. Кроме того, Германия высказалась против более крупного вклада со стороны ЕИБ из опасения подорвать его кредитный рейтинг. Из 21 млрд. евро стартового капитала 5 млрд. предназначены для компаний малого и среднего бизнеса. Денежный резерв в 21 млрд. позволил ЕИБ выдать кредиты на общую сумму в 63 млрд. евро. Эти деньги (второстепенный долг) были использованы для финансирования более рискованных элементов инвестиционных проектов.

Как правило, финансовые инструменты ЕИБ предполагают низкую степень риска. Но ЕФСИ был построен иначе. Подразумевалось, что мультипликационный эффект будет выше в случае поддержки и поощрения инвестиций с высоким уровнем риска. Каждый евро второстепенного долга должен был привлечь 4 евро частных инвестиций (первостепенный долг). Государства-члены могли внести свой дополнительный вклад, но он не был обязательным.

ЕИБ призван был организовать техническое содействие. Он должен был помочь организаторам проектов (в особенности крупных инфраструктурных, касающихся широкополосного доступа в Интернет, энергетики, образования, науки и инноваций) в их структурировании и финансировании. Речь идёт об использовании комплексных финансовых пакетов и о наращивании сотрудничества между ЕИБ и национальными банками развития, которые применяют схожие бизнес-планы.

Мобилизация кредитных ресурсов обеспечивалась тремя путями: (1) инвестирование в проекты, которые ЕС готов поддержать, (2) покупка выпускаемых ЕИБ облигаций и (3) долевое участие в ЕФСИ. К участию приглашались, помимо государств-членов, национальные банки развития, опирающиеся на государственную поддержку, региональные власти и частные инвесторы (пенсионные фонды, хедж-фонды, страховые компании, компании по управлению активами и банки).

Инвестиционный план главы Еврокомиссии (ЕК) Жан-Клода Юнкера, направленный на стимулирование экономической активности (главным образом в южной части Еврозоны) включал три направления: (а) мобилизация инвестиций без наращивания государственного долга; (б) поддержка инвестиций и капиталовложений в таких ключевых сферах, как инфраструктура, образование, исследования и инновации; (в) устранение финансовых и нефинансовых барьеров к инвестированию, т.е. продвижение к подлинно единому рынку в сферах энергетики, транспорта, цифровой экономики и телекоммуникаций, где гармонизация национальных правил задерживается.

ЕФСИ находится под общим руководством ЕИБ, но имеет собственную независимую структуру управления. Его руководящий совет включает четырёх человек (троих от Комиссии и одного от ЕИБ). Руководящий совет решает стратегические вопросы, ведёт оперативную деятельность и осуществляет риск-менеджмент. Инвестиционный комитет из восьми независимых экспертов, в свою очередь, выбирает проекты для финансирования, проводит их комплексную юридическую оценку и выделяет средства под руководством исполнительного директора. Инвестиции и займы по проектам, которые поддерживает ЕФСИ, не подлежат действию режима в рамках Пакта стабильности и роста. При этом каждый проект должен быть стоимостью не менее 10 млн. евро, он должен быть не осуществим без поддержки ЕФСИ и, в идеале, должен способствовать повышению темпов роста европейской экономики в среднесрочной и долгосрочной перспективе, как и её международной конкурентоспособности, благоприятствуя созданию новых рабочих мест.

Ключевым в данном случае выглядит взаимодействие между Европейским инвестиционным банком, Европейской комиссией, акторами субнационального уровня и частными игроками. Между ними завязывается диалог, облегчающий развитие новых методов финансирования экономики. 
Налицо большое сходство между целями, заявленными для Плана Юнкера, и целями структурных фондов в бюджете ЕС, которыми непосредственно распоряжается Комиссия. На национальном и субнациональном уровнях ЕФСИ обеспечивает координацию европейских инвестиционных проектов с деятельностью национальных банков развития ( $K f W$ в Германии, Caisse des Dépôts и Bpifrance во Франции, Instituto de Crédito Official в Испании, Cassa dei Depositi e Prestiti в Италии) и с частными инвесторами, содействуя тем самым оформлению европейского административного пространства ${ }^{322}$.

ЕФСИ действительно принадлежит заметная роль в активизации частных инвестиций в Европе. К 2018 г. удалось собрать 335 млрд. евро (при запланированных 315 млрд.). Теперь ожидается, что к 2020 г. эта цифра должна достичь 500 млрд. евро (две трети инвестиций исходят, напомним, как раз от частного сектора). В 2016 г. на волне успеха своей инициативы Юнкер предложил учредить аналогичный Внешний инвестиционный план для поощрения частных инвестиций в Африке и в странах европейского соседства ${ }^{323}$.

Нынешние экономические и социальные проблемы в Европе невозможно решить без осмысленного перераспределения богатства - внутри стран, но также и на европейском уровне (от богатых стран к относительно более бедным) ${ }^{324}$. Но бюджет Евросоюза слишком мал, чтобы обеспечивать подобное перераспределение в достаточной мере. К тому же он построен с ориентацией на иные приоритеты. Это, по преимуществу, инвестиционный бюджет для таких сфер, как энергетика, транспорт, информационные и коммуникационные технологии, борьба с изменением климата и научные исследования.

Стабилизационная функция на европейском уровне, которую теперь обсуждают в европейских правящих кругах, в любом случае может стать только дополнением к той стабилизационной роли, которую играют в ЕС национальные бюджеты. Европейская стабилизационная функция запускалась бы только в том случае, когда национальных бюджетных амортизаторов становилось недостаточно. В специальной литературе по вопросу автоматических стабилизаторов провалы рынка, дисбалансы по счёту текущих операций и эффекты перелива упоминаются в обоснование потребности ЭВС в подобном механизме.

\footnotetext{
${ }^{322}$ Kopric I. \& Kovac P., eds. (2017) European Administrative Space: Spreading Standards, Building Capacities, Bratislava: NISPAcee.

${ }^{323}$ URL: https://ec.europa.eu/europeaid/sites/devco/files/factsheet-eip-20171120_en.pdf.

${ }^{324}$ Hermann Ch. (2013) Crisis, Structural Reform and the Dismantling of the European Social Model(s)// Working Paper, Institute for International Political Economy Berlin, no. 26/2013. URL: http://hdl.handle.net/10419/83958.
} 


\section{ЗАКЛЮЧЕНИЕ}

В Европейском союзе ведение макроэкономической политики по преимуществу остаётся прерогативой государств. Появление евро не предполагало кардинального перехода к общему решению структурных проблем отдельных стран в еврозоне. Единая валюта при её создании не рассматривалась как механизм по выравниванию разнородных национальных экономических систем. Появление евро не сделало такое понятие, как «платёжный баланс», несущественным для оценки взаимоотношений государств внутри Еврозоны. Однако вместе с тем в 2010-е годы полномочия европейских институтов по координации национальных действий в области экономической политики и по мониторингу соблюдения национальными правительствами наднациональных бюджетных правил существенно укрепились. Была введена, помимо прочего, новая процедура по противодействию чрезмерным макроэкономическим дисбалансам. С созданием трёх опор Банковского союза (за исключением совместной гарантии по вкладам, до сих по не обеспеченной, которая выступает в качестве его запланированной четвёртой опоры) компетенция по управлению банковским сектором тоже переместилась на наднациональный уровень. Серьёзные изменения претерпела наднациональная денежно-кредитная политика, проводимая ЕЦБ.

В 2007-2008 гг. Европейский банк начал применять непривычные для него методы денежно-кредитной политики, насыщая валютные рынки ликвидностью, чтобы поддержать коммерческие банки, и снижал процентные ставки, а в 2010 г. в рамках программы «Securities Markets Programme» он стал выкупать на вторичном рынке государственные облигации Греции, Португалии, Ирландии, Италии, Испании (перечисленные страны испытывали трудности с выплатой суверенной долга). На смену этой программе в 2012 г. пришла новая Outright Monetary Transactions (OMT). Кроме того, для содействия росту был введён специальный инвестиционный инструмент (План Юнкера) для привлечения частных капиталовложений.

Ни один из этих новых инструментов не был оснащён элементами демократического управления наднационального уровня. В тех случаях, когда было предусмотрено принятие наднациональных решений (например, применительно к OMT и к Европейскому фонду стратегических инвестиций), они передавались на усмотрение чиновников - Комиссии и Европейского центрального банка, действующий без согласия Европейского парламента. В иных рассмотренных нами в данной книге случаях, если механизм является (остаётся) межправительственным, решения в его рамках принимают Комиссия и Совет, но ЕП опятьтаки в них по существу не вовлекается.

Укрепление власти институтов ЕС сопровождалось появлением новых методов интенсивного сотрудничества между европейским и национальным властными уровнями например, в форме описанного на страницах книги европейского семестра. Налицо оказалась тенденция к более тесному сращиванию этих двух уровней, примером чему служит, например, взаимная увязка между ЕМС и Фискальным пактом: доступ к ЕМС открыт только для тех государств, которые присоединились к Пакту. Как мы видим, гибридные формы (квази)государственного вмешательства в функционирование рынка не только возможны, но и распространяются в ЕС ради его выживания - из-за «трудного» сочетания экономической интеграции с политической децентрализацией.

Европейское экономическое управление к настоящему времени оформилось в весьма сложную, запутанную систему, в которой непросто разобраться - тем более, что она остаётся незавершённой и продолжает быстро меняться. Мотивы Европейской комиссии и ЕЦБ, принимают множество решений, остаются для широкой публики неочевидными. 
В настоящей работе были оценены сложные связи между сохранением национального суверенитета государствами - членами Европейского союза, развитием или сохранением демократии в его политической системе и укреплением Экономического и валютного союза. Логика продвижения вперёд в области ЭВС вряд ли совместима с сочетанием сразу обоих других элементов - она может более гармонично сочетаться лишь с каждым из них по отдельности ${ }^{325}$. В практике ЕС на отдельных этапах его развития правящие круги интеграционного объединения выбирали разные ответы на возникавшую таким образом трилемму.

Скажем, на начальном этапе строительства ЭВС макроэкономическая интеграция была ограничена, чтобы защитить национальные суверенитет и демократию. Однако впоследствии такое решение показало свою нежизнеспособность. В период мирового кризиса 2008-2009 гг. демократия, напротив, приносилась в жертву целям укрепления региональной интеграции при сохранении национального суверенитета в экономической сфере. Европейские правила, касающиеся бюджетно-налоговой дисциплины и макроэкономических дисбалансов, ограничили свободу действий в национальных демократических рамках, тогда как недемократические по своей сути немажоритарные институты (Комиссия, ЕЦБ) обрели более важную роль и власть в формулировании и отстаивании этих правил. Элитный характер экономического управления в ЕС в результате усилился, подрывая массовую демократию национального уровня, что спровоцировало всплеск политического экстремизма, направленного против ЕС и теперь бросающего ему экзистенциальный вызов.

Всё вышесказанное подводит нас к заключению, что на данный момент мы наблюдаем не завершение строительства ЭВС, а продолжающееся изменение основ его институциональной организации, развитие которой в очередной раз меняет своё направление. Долговременные планы централизации ЭВС предполагают не просто продолжение интеграционного процесса, но перенесение локуса (основного местоположения) демократии на европейский уровень, что возможно только за счёт дальнейшего ущемления национального суверенитета. При этом если национальные суды будут систематически продолжать настаивать на защите суверенитета и национальной демократии, то сложившаяся система управления ЭВС вряд ли сможет эффективно работать, чем будет нанесён огромный урон легитимности Европейского союза «на выходе».

Европейский союз, не имеющий наднациональной власти в вопросах налогообложения, с очень ограниченными бюджетными ресурсами европейского уровня, не располагает достаточным самостоятельным потенциалом, чтобы поддерживать финансовую стабильность и обеспечить надёжную опору для общей валюты. В то же время процесс фискальной интеграции в Европейском союзе идёт очень медленно и приносит противоречивые плоды. С одной стороны, она остаётся недостаточно развитой, чтобы способствовать укреплению легитимности европейской системы экономического управления «на выходе» (через обеспечение удовлетворительных для граждан результатов европейской политики). С другой стороны, новые элементы европейской структуры, призванные ограничить свободу национальных действий и укрепить власть обособленных европейских институтов в финансовых вопросах, усугубляют демократический дефицит в системе ЕС (подрывают легитимность «на входе»).

Антикризисные меры, которые ныне предлагает Европейская комиссия, имеют ограниченный перераспределительный эффект и, по предположениям большинства экспертов, останутся недостаточно эффективными, но при этом национальные правительства зачастую ограничиваются наднациональной властью в возможности задействовать

\footnotetext{
${ }^{325}$ По этому поводу см., например, Rodrik D. (2011) The Globalization Paradox. Democracy and the Future of the World Economy, New York and London: W.W. Norton. См. также: Snell Jukka (2016) The Trilemma of European Economic and Monetary Integration, and its Consequences // European Law Journal, vol. 22, issue 2, pp. $157-179$. Available at SSRN: https://ssrn.com/abstract=2772283 or http://dx.doi.org/10.1111/eulj.12165 .
} 
перераспределительные меры на своём уровне. Ситуация складывается таким образом, что бюджетно-налоговая сфера оказывается в ЕС вообее вне действенного парламентского контроля (будь то национального или наднационального), что лишает европейских граждан возможности подключиться к принятию решений, принципиально значимых с точки зрения существа демократии. Выражаясь кратко, те формы, которые реально сейчас носит фискальная интеграция в Европе, решительным образом ставят под удар демократическое качество политической системы Европейского союза.

Демократизация в условиях фискальной интеграции по существу требует усиления власти Европейского парламента, наделения его наднациональными полномочиями по принятию решений в вопросах бюджетно-налоговой и экономической политики. Но такое институциональное решение невозможно при сохранении эксклюзивной национальной идентичности. Последняя связана с укоренившимся представлениями, что бюджетноналоговая политика, с её перераспределительными последствиями, может быть предметом рассмотрения в рамках демократического принятия решений только для национального демоса. Отсюда следует, что обнаружение надёжного источника для общей европейской идентичности сегодня выступает в качестве важного приоритета и непреложного условия для дальнейшей европейской фискальной интеграции. В противном случае ЕС рискует надолго получить дисфункциональную систему управления, необходимые решения в которой на фоне периодически возрастающей нестабильности на европейских финансовых рынках будут блокировать парламенты разного уровня.

Сложившуюся институциональную архитектуру еврозоны в целом можно охарактеризовать как непропорциональную. Она ведёт своё начало от достижения европейской элитой к 1980-м годам согласия по поводу преимуществ монетаристского подхода касательно управления экономикой. На этом основании в Брюсселе было решено, что главные гарантии макроэкономической стабильности в еврозоне будут обеспечены независимым центральным банком, заботящимся, в первую очередь, о ценовой стабильности. Триумф монетаризма и его вклад в достижение общего элитного консенсуса по данному вопросу были тесно связаны с очевидными провалами ранее доминировавшей кейнсианской парадигмы, которая в период с конца 1960-х и по начало 1980-х годов оказалась не в состоянии объяснить и тем более разрешить затяжные проблемы, связанные с новым для того времени явлением стагфляции, при которой экономический спад и депрессивное состояние экономики сочетались с ростом инфляции.

Выбор монетарной политики как ключевого инструмента стабилизации тем более оказался в Европе ко двору в политическом плане, что он, как казалось, на том этапе не требовал немедленной централизации особо чувствительных в политическом отношении областей, прежде всего бюджетно-налоговой политики, которую национальные правительства хотели оставить за собой. При том, что в Европе звучали и предостерегающие голоса относительно жизнеспособности задуманной схемы, в принципе монетаризм обеспечил наименьший общий знаменатель, фундаменте которого элиты смогли в начале 1990-х годов договориться начать строить ЭВС на базе Маастрихтского договора. Они пришли к заключению, что общая европейская валюта достижима и без сопоставимой с нею фискальной интеграции, которую их предшественники считали для неё жизненно необходимой (что подтверждается содержанием плана Вернера 1970-х годов).

По условиям достигнутого в 1990-е годы консенсуса, частные рынки призваны были компенсировать отсутствие достаточного по объёму общего бюджета и мощных федеральных институтов. Установившаяся интеллектуальная гегемония неолиберализма, с которой практически никто всерьёз не спорил, обеспечивала оправдание для европейского валютного союза, построенного по довольно-таки драконовскому с точки зрения широких общественных интересов принципу «ничего лишнего». 
Хотя по истечении четверти века с тех пор оказалось, что валютный союз при свободном движении капитала, отсутствии в системе надёжного кредитора последней инстанции и/или без достаточного по объёму федерального бюджета неработоспособен и является весьма рискованным, обоснованным выглядит и взвешенный скептицизм российского специалиста С.Л. Ткаченко по поводу звучащих сейчас призывов вернуться в Европе к широкой реализации мер, традиционно приписываемых ортодоксальному кейнсианству: «...Меры по финансированию бюджетных расходов за счет заимствованных на рынке средств, которые США как мировой лидер в середине 1990-х годов могли себе легко позволить, сегодня приведут к катастрофическим последствиям для еврозоны и единой валюты. Возможно, осторожное наращивание номинированного в евро долга и более терпимое отношение к дефициту национальных бюджетов допустимы» ${ }^{326}$.

Альтернативный решительной централизации подход к европейской фискальной политике предлагают некоторые эксперты, говоря о желательности её «дезинтеграции». Такой парадоксальный, на первый взгляд, вариант продиктован признанием сложных политических реалий существования ЭВС (в том числе международных), наличия резких расхождений в национальных предпочтениях и/или принципиальным недоверием к реализуемости перспективы передачи налоговых компетенций на европейский уровень. По их мнению, предпочтительной для ЕС на перспективу является система с децентрализованной ответственностью за суверенные долги, но с более жёсткой рыночной дисциплиной, а также с открытыми возможностями по реструктуризации суверенного долга и с реформами, направленными на снижения риска возникновения экономических шоков ${ }^{327}$. Так, Айхенгрин и Выплош, в частности, полагают, что негативные экстерналии национальной фискальной политики в еврозоне в принципе недостаточно велики, чтобы отказываться из-за них от следования предпочтениям, специфичным для каждой отдельной страны ${ }^{328}$.

В определении бывшего главы ЕЦБ Жан-Клода Трише, реализованная модель европейского экономического управления, представляет собой «федерализм в качестве исключения» (federalism by exception), при котором только страны, самостоятельно не справляющиеся с макроэкономическим управлением (и якобы сами в этом виноватые), помещаются под недемократичное управление европейской администрации. Но европейская стратегия, казавшаяся приемлемой для бюрократов в Брюсселе, во Франкфурте-на-Майне и в Страсбурге, уже получила самые злокачественные политические последствия в таких странах, как Греция, Испания и Италия, вызвав массовое отторжение. Сегодня речь идёт о том, что от такой модели разумнее отказаться, что она, по крайней мере, нуждается в серьёзной коррекции.

С образованием Европейского механизма стабильности, который можно назвать зародышевым аналогом Международного валютного фонда для еврозоны, удалось получить постоянный фискальный инструмент для финансовой поддержки стран, испытывающих проблемы с ликвидностью, и даже для (прямой) рекапитализации банков. Но при этом полезно учесть, что объём ЕМС равен всего только 6\% совокупного ВНП стран еврозоны и потому недостаточен для поддержки в случае необходимости таких крупных стран, как Испания или Италия, при возникновении у них серьёзных финансовых проблем. Главное же, что

\footnotetext{
326 Ткаченко С.Л. (2017) Еврозона: проблемы и перспективы. Обсуждение кн.: Stiglitz J.E. The Euro. How a Common Currency Threatens the Future of Europe, New York; London: W.W. Norton \& Company, 2016 // Вестник СПбГУ. Экономика, Т. 33, Вып. 2, с. 329. URL: https://cyberleninka.ru/article/n/evrozona-problemy-i-perspektivy. ${ }^{327}$ Fuest Clemens and Peichl Andreas (2012) European Fiscal Union: What Is It? Does It work? And Are There Really 'No Alternatives'? // IZA Policy Paper, No. 39, pp. 1-10. URL: http://ftp.iza.org/pp39.pdf; Dolls Mathias, Fuest Clemens, Heinemann Friedrich,Peichl Andreas (2016) Reconciling Insurance with Market Discipline: A Blueprint for a European Fiscal Union // CESifo Working Paper, No. 5767. URL: https://pdfs.semanticscholar.org/16a1/2bd4aa501214ca5d660fdae945245e668376.pdf.

${ }^{328}$ Eichengreen Barry and Wyplosz Charles (2016) Minimal Conditions for the Survival of the Euro // Intereconomics, volume 51 , issue 1 , pp 24-28.
} 
необходимо подчеркнуть, так это то, что цель ЕМС - противодействие системным рискам и предотвращение негативных экстерналий в еврозоне, т.е. обеспечение финансовой стабильности, а не экономической стабилизации каковая, в свою очередь, требуется для преодоления асимметричных шоков.

В качестве важного инструмента европейского риск-менеджмента следует ещё раз вспомнить о «прямых денежных операциях»-Outright Monetary Transactions. Вооружившись этим потенциально мощным инструментом, ЕЦБ теперь в принципе способен выступать как кредитор последней инстанции для государств-членов еврозоны, выкупая их долговые обязательства на вторичном рынке под условия жёсткой кондициональности. Однако, в отличие от правительств, Европейский центральный банк, в силу своих институциональных характеристик, не должен продвигать кондициональность сам по себе. В противном случае он попадает на (политическое) «минное поле», от чего страдают его репутация и независимость. C внедрением OMT была предпринята попытка обойти возникшее затруднение, так как эта программа может быть задействована только в отношении стран, «добровольно» согласившихся на условия получения официальной финансовой помощи по линии ЕМС, имеющего в данном отношении относительно более легитимное институциональное оформление. Но и здесь полностью не снимается проблема так называемого риска недобросовестности (moral hazard): в большей мере, нежели средства чрезвычайных фондов, финансируемые правительствами - таких, как ЕМС - деньги, исходящие от ЕЦБ, в любом случае воспринимаются на национальном уровне как «бесхозные», «дармовые» возникающие как бы из воздуха. Тот факт, что у ЕЦБ на самом деле нет ограничений в средствах (наличествует возможность «включить печатный станок»), означает, что политические власти всех стран ЭВС понимают: кое-где в потенциале всегда найдётся достаточно денег, чтобы кого-то из них можно было спасти в любом случае. Это, как опасаются, например, в Германии, действительно может подталкивать отдельные национальные правительства к более легкомысленному экономическому поведению. В долговременном плане применение $O M T$ может иметь негативные побочные последствия, поскольку функция кредитора последней инстанции способна помешать ЕЦБ в выполнении его ключевого мандата по линии денежно-кредитной политики, порождая инфляционные риски.

Для того, чтобы формально запрещать ЕЦБ финансирование правительств напрямую, сохраняются достаточно веские политические основания. Если прочие центральные банки в мире взаимодействуют с единым правительством, то ЕЦБ, за отсутствием единого правительства в еврозоне, приходится иметь дело с девятнадцатью суверенами. Когда Банк приобретает правительственные долги, такое приобретение неизбежно имеет распределительный (между странами) эффект. Когда ЕЦБ несёт потери по линии своего облигационного портфеля, они переносятся на его стейкхолдеров - т.е. на государства еврозоны. Таким образом ЕЦБ становится каналом для бюджетных трансфертов в пользу стран, которые от покупок ЕЦБ выигрывают, тогда как у самого ЕЦБ нет на такие действия ни мандата, ни достаточной демократической легитимности.

Меры по развитию ЭВС, проанализированные в настоящей монографии, важны в плане гармонизации и централизации принятия европейских решений и финансового надзора. Они в большинстве своём способствуют углублению сотрудничества стран еврозоны в борьбе с проблемами суверенных долгов. Важным средством укрепления стабильности ЭВС стало настойчивое строительство трёх опор Банковского союза. Но внедрение принципа «bail-in» само по себе опять-таки не устраняет полностью риск того, что банковские кризисы будут и впредь дестабилизировать национальные бюджеты, а потому отсутствие до сих пор общей фискальной страховки в дополнение к национальным составляет для европейских правящих кругов немаловажную заботу. 
В качестве средства стабилизации ЭВС в специальной литературе до сих пор предлагается, помимо прочего, внедрение единых евробондов ${ }^{329}$, совместно выпускаемых странами еврозоны. Потенциально их стабилизирующая способность (помощь более слабым странам) действительно велика. Инвесторы могут в принципе проявить больше интереса к облигациям, выпущенным от лица всего региона, нежели отдельно Италией или Испанией. Но и здесь не избежать риска недобросовестности национальных правительств, если их доступ к этому инструменту окажется неограниченным.

Преобладающее внимание в настоящей книге было уделено организационным вопросам и сюжетам. Автор руководствовалась убеждением, что организационные механизмы представляют собой нечто гораздо большее, нежели второстепенные, якобы не заслуживающие особого внимания, детали того или иного института экономического управления. Организационные особенности институтов относятся к числу важнейших факторов, определяющих институциональную эволюцию ЕС в целом. Поэтому критика в адрес любого института должна быть пропущена через фильтр осознания его принадлежности к определённому организационному типу - с сопутствующими ему ограничениями. С помощью всякого определённым образом организованного института можно добиться ровным счётом того, для чего его на самом деле сконструировали, а вовсе не того, чего бы захотелось потом его критикам или «унаследовавшим» данный институт от предшественников элитам, ищущим ему новые применения.

Европейский союз - не традиционное государство, а беспрецедентно новая форма реализации политической власти. Однако, как и у «обычных» государств, его успех зависит от технологий осуществления власти - инструментария, который в данном случае изобретательно заимствуется европейским правящим классом из разных источников - чтобы функционировать в качестве управляющего центра или восполнять отсутствие такого центра. Поэтому систему управления ЭВС полезно анализировать на достаточном уровне абстракции - как гибрид или композит властных технологий.

Снять проблему демократического дефицита в ЕС позволило бы построение полномасштабного политического союза, включающего создание «экономического правительства» с наделённым серьёзными полномочиями европейским министром финансов для координации экономической, бюджетной и социальной политики в еврозоне, которое обсуждается с 2012 г. Но если президент Франции Эммануэль Макрон выступает за превращение еврозоны в «трансферный» союз с собственным парламентом, который контролировал бы расходы собственного бюджета еврозоны (ныне не существующего), то Германия не готова разделить столь смелый планы, опасаясь, что это увеличит её расходы, и из Берлина подобный парламент пока видится исключительно в консультативной роли (к тому же его создание входит в противоречие с институциональными интересами Европейского парламента).

В принципе маловероятно, что построить политический союз на базе ЕС удастся в ближайшем будущем. Представляется сомнительным, чтобы подобное решение получило достаточную поддержку со стороны граждан в условиях широкого распространения евроскептических настроений. Оформлению политического союза мешают не только трения между разными институциональными уровнями власти (европейским и национальным), но и поляризация национальных предпочтений государств-членов относительно того, в чём состоит общий европейский интерес.

\footnotetext{
${ }^{329}$ Gilbert Niels, Hessel Jeroen and Verkaart Silvie (2013) Towards a Stable Monetary Union: What Role for Eurobonds? // De Nederlandsche Bank NV Working Paper, No. 3. URL: https://www.dnb.nl/en/binaries/Working\%20Paper\%20379_tcm47-291377.pdf. 
С учётом этого более глубокий фискальный союз, сам по себе, не является сегодня ни необходимым, ни достаточным условием для эффективной политики экономической стабилизации в интегрированной Европе. Фискальная интеграция затрагивает самое ядро демократических систем. Поэтому европеизацию в фискальной сфере - будь то укрепление межправительственного сотрудничества или передача на верхний уровень власти все новых компетенций - нельзя считать изменением само собой разумеющимся и не требующим дополнительных раздумий со стороны экспертов и власть имущих, как и со стороны широкой публики - с точки зрения того, как они вписываются в общую картину интеграционного развития. Меры в этой области, до сих пор предпочитаемые в Брюсселе, могут в долговременном плане обернуться неприятностями и вызвать рикошет: они не обеспечивают в должной мере демократической легитимности «на входе» в политическую систему Европейского союза, что, в противоположность желаемому, не облегчает, а как раз осложняет решение задач его долговременного выживания и подлинного прогресса. 


\section{СПИСОК ЛИТЕРАТУРЫ}

Андрюшин С., Кузнецова В. (2012) Инструменты макропруденциальной политики центральных банков // Вопросы экономики, №8. М.: «Редакция журнала «Вопросы экономики»»), с. 32-47. \{Andryushin S., Kuznecova V. (2012) Instrumenty makroprudencial'noj politiki central'nyh bankov [Instruments of macdroprudential policy of central banks] // Voprosy ehkonomiki, № 8, M.: «Redakciya zhurnala «Voprosy ehkonomiki»»), pp. 32-47\}

Бабынина Л.О. (2014) Трансформация внутренней архитектуры ЕС: проблемы фрагментации политического пространства // Политическая наука. М., ИНИОН, № 2, с. 44-64. \{ Babynina L.O. (2014) Transformaciya vnutrennej arhitektury ES: problemy fragmentacii politicheskogo prostranstva // Politicheskaya nauka. M.: INION, № 2, pp. 44-64\}

Борко Ю.А. (2007) Свет и тени европейской интеграции // Россия в глобальной политике, №1. \{Borko YU.A. (2007) Svet i teni evropejskoj integracii // Rossiya $\boldsymbol{v}$ global'noj politike, №1\} URL: http://www.globalaffairs.ru/number/n_8140.

Борко Ю.А. (2006) Взаимосвязь процессов расширения и углубления европейской интеграции // Расширение Европейского Союза и Россия / Под. ред. О.В. Буториной и Ю.А. Борко. М.: Деловая литература, с. 1142. \{Borko YU.A. (2006) Vzaimosvyaz' processov rasshireniya i uglubleniya evropejskoj integracii [Interrelation between the processes of enlargement and deapening in European integration] // Rasshirenie Evropejskogo Soyuza i Rossiya [Enlargement of the European Union and Russia] / Ed. by. O.V. Butorinoj i YU.A. Borko. M.: Delovaya literatura, pp. 11-42\}

Буторина О.В. (2018) Монетарная политика ЕЦБ: новейшие тенденции // Межљународная экономика, № 1, с. 37-49. \{Butorina O.V. (2018) Monetarnaya politika ECB: novejshie tendencii [Monetary Policy of the ECB: the new trends] // Mezhdunarodnaya ehkonomika, № 1, pp. 37-49\}

Буторина О. и Цибулина А. (2018) Европейская инфляционная аномалия: источники и риски. 12 апреля. \{Вutorina O. and Cibulina A. (2018) Evropejskaya inflyacionnaya anomaliya: istochniki i riski. 12 April\} URL: $\mathrm{http}: / /$ russiancouncil.ru/analytics-and-comments/analytics/evropeyskaya-inflyatsionnaya-anomaliya-istochnikii-riski/.

Буторина О.В. (2017) Негативные и позитивные задачи Европейского валютного союза // Современная Европа, № 2, c. 18-29. \{Butorina O.V. (2017) Negativnye i pozitivnye zadachi Evropejskogo valyutnogo soyuza [Negative and positive tasks of the European Monetary Union] // Sovremennaya Evropa, № 2, pp. 18-29\}

Герасимов В.П. (2016) Механизм финансовой стабилизации в современной Европе // Финансовая аналитика: проблемы и решения, №10, с. 42-53. \{Gerasimov V.P. (2016) Mekhanizm finansovoj stabilizacii v sovremennoj Evrope [mechanism of financial stabilization in modern Europe] // Finansovaya analitika: problemy $\mathrm{i}$ resheniya, №10, pp. 42-53\}

Громогласова Е.С. (2009). Теория и практика политического управления в Европейском союзе, М.: ИМЭМО PAH. \{Gromoglasova E.S. (2009). Teoriya i praktika politicheskogo upravleniya v Evropejskom soyuze [Theory and practice of political governance in the European Union], M.: IMEHMO RAN\}

Европейская интеграция: Учебник для вузов / Под ред. О.В. Буториной (отв. ред.), Н.Ю. Кавешникова. 2-е изд., М.: Аспект Пресс, 2016. \{Evropejskaya integraciya: Uchebnik dlya vuzov [European integration: textbook for higher education] / Pod red. O.V. Butorinoj (otv. red.), N.YU. Kaveshnikova. 2-e izd., M.: Aspekt Press, 2016$\}$

Кавешников Н.Ю. (2011) Гибкая интеграция» в Европейском союзе // Международные процессы, том 9 , № 2 (26), c. 58-69. \{Kaveshnikov N.YU. (2011) Gibkaya integraciya» v Evropejskom soyuze // Mezhdunarodnye processy, vol. 9, № 2 (26), pp. 58-69\}

Кейнс Джон Мейнард (2007) Общая теория занятости, процента и денег, М.: Эксмо. \{Keines John Meynard (2007) Obshchaya teoriya zanyatosti, procenta i deneg [The General Theory of Employment, Interest, and Money], M.: EHksmo\} 
Клёмин А.В. (2010) О соотношении национального и европейского права // Актуальные проблемы экономики и права, №2, с. 184-194. \{Klyomin A.V. (2010) O sootnoshenii nacional'nogo i evropejskogo prava [On the correlation between national and European law] // Aktual'nye problemy ehkonomiki i prava, №2, pp. 184-194\} URL: http://apel.ieml.ru/storage/archive_articles/9275.pdf.

Линде А.Н. (2015) Делиберативная демократия как направление в современной теории демократии: анализ основных подходов // Проблемный анализ и государственно-управленческое проектирование, том 8, c. 52-58. \{Linde A.N. (2015) Deliberativnaya demokratiya kak napravlenie v sovremennoj teorii demokratii: analiz osnovnyh podhodov [Deliberative democracy as an orientation in the modern democracy theory: analysis of the key approaches] // Problemnyj analiz i gosudarstvenno-upravlencheskoe proektirovanie, tom 8, pp. 52-58\}

Лицарева Е. Ю. (2012) Позиции стран ЕС в отношении выхода из экономического кризиса 2008 г. // Вестник Томского государственного университета, № 365, с. 69-76. \{Licareva E. YU. (2012) Pozicii stran ES v otnoshenii vyhoda iz ehkonomicheskogo krizisa $2008 \mathrm{~g}$. [Positions of the EU member states as concerns management of the 2008 economic crisis] // Vestnik Tomskogo gosudarstvennogo universiteta, № 365, pp. 6976\} URL: http://vital.lib.tsu.ru/vital/access/manager/Repository/vtls:000438553.

Новикова О.Н. (2005) «Дефицит демократии» в ЕС: основные направления критического анализа проблемы (обзор) // Актуальные проблемы Европы, № 4, с. 79-104. \{Novikova O.N. (2005) «Deficit demokratii» v ES: osnovnye napravleniya kriticheskogo analiza problemy (obzor) ["Democratic deficit" in the EU: the main directions of the critical analysis of the problem (survey)] // Aktual'nye problemy Evropy, № 4, pp. 79-104\}

Осокина Е.Б. (2017) Предпосылки и основные положения реформы правового регулирования банковской деятельности в ЕС // Право и управление. ХХІ век, № 1, с. 66-74. \{Osokina E.B. (2017) Predposylki i osnovnye polozheniya reformy pravovogo regulirovaniya bankovskoj deyatel'nosti $\mathrm{v}$ ES [Prerequisites and conceptual issues of the reform of the legal regulation of banking activity in the EU] // Pravo i upravlenie. XXI vek, № 1, pp. 66-74\}

Патрушев С. (2001) Институционализм в политической науке: этапы, течения, идеи, проблемы // Зарубежсная политология в XX столетии: Сб. науч. тр. / РАН ИНИОН. Отв. ред. вып. Ильин М.В. Москва, № 2, pр. 146-186. \{Patrushev S. (2001) Institucionalizm v politicheskoj nauke: ehtapy, techeniya, idei, problemy [Institutionalism in Political Science: stages, schools, ideas, problems] // Zarubezhnaya politologiya $\boldsymbol{v} X \boldsymbol{X}$ stoletii: Sb. nauch. tr. / RAN INION. Otv. red. vyp. Il'in M.V. Moskva, № 2, pp. 146-186\} URL: http://pavroz.ru/files/patrushevinst.pdf.

Пашкевич А. и Власенко М. (2017) Инструменты макропруденциальной политики: европейский опыт, перспективы для Беларуси // Банкаўскі веснік, май, с. 3-11. \{Pashkevich A. and Vlasenko M. (2017) Instrumenty makroprudencial'noj politiki: evropejskij opyt, perspektivy dlya Belarusi // Bankay̆ski vesnik, May, pp. 3-11\} URL: https://www.nbrb.by/bv/articles/10385.pdf.

Пашковская И.Г. (2016) Деятельность Европейского Союза по актуализации правовых основ Экономического и валютного союза после мирового финансового и экономического кризиса 2008 года // Мировая политика, № 2. \{Pashkovskaya I.G. (2016) Deyatel'nost' Evropejskogo Soyuza po aktualizacii pravovyh osnov EHkonomicheskogo i valyutnogo soyuza posle mirovogo finansovogo i ehkonomicheskogo krizisa 2008 goda // Mirovaya politika, № 2.\} URL: http://e-notabene.ru/wi/article_19140.html.

Семененко И., Прохоренко И. (2015) От проекта элит к массовой политике: вызовы политизации европейской интеграции // Мировая экономика и международные отношения, № 7, с. 29-40. \{Semenenko I., Prohorenko I. (2015) Ot proekta ehlit k massovoj politike: vyzovy politizacii evropejskoj integracii [From an elite project to mass politics: challenges of the politicization of European integration] // Mirovaya ehkonomika i mezhdunarodnye otnosheniya, № 7, s. 29-40\}

Смирнов Е. Н. (2014) Риски развития современной экономики Европейского союза как отражение кризиса национальных моделей социально-экономического развития // Интернет-жжурнал “Науковедение», выпуск 6 (25), ноябрь-декабрь. \{Smirnov E. N. (2014) Riski razvitiya sovremennoj ehkonomiki Evropejskogo soyuza kak otrazhenie krizisa nacional'nyh modelej social'no-ehkonomicheskogo razvitiya // Internet-zhurnal «Naukovedenie», vypusk 6 (25), noyabr'-dekabr'\} URL: https://naukovedenie.ru/PDF/160EVN614.pdf. 
Стрежнева М. (2009) Структурирование политического пространства в Европейском союзе // Мировая экономика и международные отношения, № 12, с. 38-49. \{Strezhneva M. V. (2009). Strukturirovanie politicheskogo prostranstva $\mathrm{v}$ evropejskom soyuze [Structuring of political space in the European Union] // Mirovaya ehkonomika I mezhdunarodnye otnosheniya, № 12, pp. 38-49\}

Теория хозяйственного порядка. «Фрайбургская икола» и немецкий неолиберализм / Под ред. В.П. Гутника Москва: Экономика, 2002, серия "Экономическое наследие". \{Teoriya hozyajstvennogo poryadka. "Frajburgskaya shkola» i nemeckij neoliberalizm [Theory of the Economic Order. «Freiburg School» and German neoliberalism] / Ed. by V.P. Gutnik - Moskva: Ekonomika, 2002, ceriya «EHkonomicheskoe nasledie»\}

Ткаченко С.Л. (2017) Еврозона: проблемы и перспективы. Обсуждение кн.: Stiglitz J.E. The Euro. How a Common Currency Threatens the Future of Europe. New York; London: W.W.Norton \& Company, 2016. // Вестник СПбГУ. Экономика, Т. 33, Вып. 2, с. 327-330. \{Tkachenko S.L. (2017) Evrozona: problemy i perspektivy. Obsuzhdenie kn.: Stiglitz J.E. The Euro. How a Common Currency Threatens the Future of Europe. New York; London: W.W.Norton \& Company, 2016. // Vestnik SPbGU. EHkonomika, T. 33, Vyp. 2, pp. 327-330\} URL: https://cyberleninka.ru/article/n/evrozona-problemy-i-perspektivy.

Топорнин Н.Б. (2015) Некоторые аспекты правового статуса и деятельности механизмов финансовой помощи в Европейском союзе // Деньги и кредит, №10, с. 58-61. \{Topornin N.B. (2015) Nekotorye aspekty pravovogo statusa i deyatel'nosti mekhanizmov finansovoj pomoshchi v Evropejskom soyuze [Certain aspects of the legal status and functioning of the instruments of financial support in the European Union] // Den'gi i kredit, №10, pp. $58-61\}$

Транснациональные политические пространства: явление и практика / Под ред. М.В. Стрежневой - М.: Весьмир, 2011. \{Transnacional'nye politicheskie prostranstva: yavlenie i praktika [Transnational political spaces: phenomenon and practice] / Ed. by M.V. Strezhneva - M.: Ves'mir, 2011\}

Туркина А.В. (2017) Новые стадии процедуры чрезмерного дефицита бюджета государств - членов Европейского союза и оценка их эффективности // Вестник Балтийского федерального университета им. И. Канта. Сер.: Гуманитарные и общественные науки, № 4, с. 11-17. \{Turkina A.V. (2017) Novye stadii procedury chrezmernogo deficita byudzheta gosudarstv - chlenov Evropejskogo soyuza i ocenka ih ehffektivnosti [New stages of the the excessive budget deficit procedure] // Vestnik Baltijskogo federal'nogo universiteta im. I. Kanta. Ser.: Gumanitarnye i obshchestvennye nauki, № 4, pp. 11-17\} URL: https://cyberleninka.ru/article/n/novye-stadii-protsedury-chrezmernogo-defitsita-byudzheta-gosudarstvchlenov-evropeyskogo-soyuza-i-otsenka-ih-effektivnosti.

Туркина А.В. (2016) Европейский стабилизационный механизм и правовая система Европейского союза // Усnехи современной науки, том 3, № 9, с. 142-148. \{Turkina A.V. (2016) Evropejskij stabilizacionnyj mekhanizm i pravovaya sistema Evropejskogo soyuza // Uspekhi sovremennoj nauki, vol. 3, № 9, pp. 142-148.\}

Фрумак И.В. (2013) Процесс формирования Еврозоны // Вестник Камчатского государственного технического университета, № 26, с. 80-92. \{Frumak I.V. (2013) Process formirovaniya Evrozony [The process of forming the Eurozone] // Vestnik Kamchatskogo gosudarstvennogo tekhnicheskogo universiteta, №26, pp. 80-92.\}

Худокормов А., Невский С. (2017) Национальные экономические школы в Германии и теория социального рыночного хозяйства // Экономическая политика, том 12. № 4, с. 204-249\{Hudokormov A., Nevskij S. (2017) Nacional'nye ehkonomicheskie shkoly v Germanii i teoriya social'nogo rynochnogo hozyajstva [The National Economic School in Germany and the theory of social market econonmy] // Ekonomicheskaya politika, vol. 12. № 4, pp. 204-249\}

Худякова Л.С., Сидорова Е.А. (2014) Реформа регулирования финансового сектора в Европейском союзе // Деньги и кредит, № 4, с. 28-34. 
Цибулина Анна (2015) Союз рынков капитала: еще один союз в ЕС // Bcя Eвpona, №11(104). \{Cibulina Anna (2015) Soyuz rynkov kapitala: eshche odin soyuz v ES [Capital Markets Union: another union in the EU]// Vsya Evropa, №11(104)\} URL: http://alleuropalux.org/?p=12373.

Цибулина А.Н. (2014) Банковский и фискальный союзы в ЕС: что важнее? // Вестник МГИМО-Университета, № 4, c. 155-161. \{Cibulina A.N. (2014) Bankovskij i fiskal'nyj soyuzy v ES: chto vazhnee? [Banking or fiscal unions in the EU: What is more important?] // Vestnik MGIMO-Universiteta, № 4, pp. 155-161\} URL: http://ehd.mgimo.ru/IORManagerMgimo/file?id=8BDAA890-5559-BE7A-5C0B-699F05687176.

Цибулина А.Н. (2013) Экономический и валютный союз ЕС: работа над ошибками // Вестник МГИМОУниверситета, № 4(31), с. 113-119. \{Cibulina A.N. (2013) Ehkonomicheskij i valyutnyj soyuz ES: rabota nad oshibkami [Economic and Monetary Union of the EU: errors correction] //Vestnik MGIMO-Universiteta, № 4(31), pp. 113-119\} URL:

http://www.vestnik.mgimo.ru/sites/all/themes/adaptivetheme/professional_theme/vestnik(4-31-2013).pdf.

Alcidi C. and Thirion G. (2016) Assessing the Effect of Shocks in the Euro Area's Shock Absorption Capacity - Risksharing, consumption smoothing and fiscal policies // CEPS Special Report, No. 146, CEPS, Brussels, March. URL:

https://www.ceps.eu/system/files/SR146\%20EUBS\%20Assessing\%20the\%20euro\%20area\%E2\%80\%99s \%20 shock-absorption\%20capacity.pdf.

Alessi Ch. (2013) Germany's Central Bank and the Eurozone. URL: https://www.cfr.org/backgrounder/germanyscentral-bank-and-eurozone.

Allard C., Brooks P.K., Bluedorn J.C., Bornhorst F., Christopherson, K. Ohnsorge F. and Poghosyan T. (2013) Toward a Fiscal Union for the Euro Area // IMF Staff Discussion Note, No. 13/09, Washington, D.C.

Amtenbrink F. (1999) The Democratic Accountability of Central Banks: A Comparative Study of the European Central Bank, Oxford: Hart.

Andrews D. (2003) The Committee of Central Bank Governors as a source of rules //Journal of European Public Policy, vol.10, issue 6, December, pp. 956-973.

Arestis P. and Sawyer M. (2013) Must we move to a United States of Europe // Challenge, vol. 56, no. 3, pp. 42-52.

Art D. (2015) The German Rescue of the Eurozone: How Germany Is Getting the Europe It Always Wanted // Political Science Quarterly, volume 130, number 2, pp. 181-212. URL: https://as.tufts.edu/politicalscience/sites/all/themes/asbase/assets/documents/art/germanRescueOfTheEurozone. pdf.

Baldwin R., Skudelny F. and Taglioni D. (2005) Trade effects from the euro: evidence from sectoral data // European Central Bank, WORKING PAPER SERIES, no 446, February. URL: https://www.ecb.europa.eu/pub/pdf/scpwps/ecbwp446.pdf.

Balls E, Howat J, Stansbury A. (2016) Central Bank independence revisited: after the financial crisis, what should a model central bank look like? // M-RCBG Associate working paper, no. 67, Harvard Kennedy School of Government. URL: https://www.hks.harvard.edu/sites/default/files/centers/mrcbg/files/67_central.bank.v.2.pdf.

Bartl M. (2015) The Way We Do Europe: Subsidiarity and the Substantive Democratic Deficit // European law Journal, vol.21, issue 1, pp. 23-43.

Batsaikhan Uuriintuya, Darvas Zsolt and Gonçalves Raposo Inês (2018) People on the move: migration and mobility in the European Union // Bruegel Blueprint Series, Vol.ME XXVIII, Brussels, Belgium: Bruegel, pp. 63-64. URL: http://bruegel.org/wp-content/uploads/2018/01/People_on_the_move_ONLINE.pdf.

Beck Th. and Kotz H.-H., eds. (2017) Ordoliberalism: $\boldsymbol{A}$ German oddity? London: CEPR Press. A VoxEU.org eBook. URL: https://ces.fas.harvard.edu/uploads/files/Reports-Articles/Ordoliberalism-A-German-Oddity-By-HansHelmut-Kotz.pdf. 
Beer Ch. and Waschiczek W. (2018) Capital markets union: a more diverse financial landscape in the EU? // Monetary Policy \& the Economy, Oesterreichische Nationalbank (Austrian Central Bank), issue Q2/18, pp. 71-86. URL: https://ideas.repec.org/a/onb/oenbmp/y2018iq2-18b4.html.

Begg I, Hodson D., Maher I. (2003) Economic Policy Coordination in the European Union // National Institute Economic $\begin{array}{lllll}\text { Review, no } & 183, & \text { pp. } & 66-77 . & \text { URL: }\end{array}$ http://citeseerx.ist.psu.edu/viewdoc/download?doi=10.1.1.470.9409\&rep=rep1\&type=pdf.

Beker V. and Moro B. (eds.) (2016) The European Crisis, Bristol, UK: World Economic Association Books Conference Series.

Bekker Sonja (2016) Is There Flexibility in the European Semester Process? Exploring Interactions between the EU and Member States within Post-Crisis Socio-Economic Governance // Tilburg Law School Research Paper, No. 10/2016. Available at SSRN: https://ssrn.com/abstract=2743238 or http://dx.doi.org/10.2139/ssrn.2743238 .

Bekkers V., Edwards A. (2007) Legitimacy and Democracy: A Conceptual Framework for Assessing Governance Practices // V. Bekkers, G. Dijkstra, A. Edwards and M. Fenger (eds.) Governance and the Democratic Deficit: Assessing the Democratic Legitimacy of Governance Practices, Aldershot, Hampshire: Ashgate, pp. 35-60.

Belke A. (2014) Monetary dialogue 2009-2014: Looking backward, looking forward // ROME Discussion Paper Series, No. 14-02, Forschungsnetzwerk 'Research on Money in the Economy' (ROME), Düsseldorf. URL: https://www.econstor.eu/bitstream/10419/98657/1/785490760.pdf.

Bellamy R. and Weale A. (2015) Political legitimacy and European monetary union: contracts, constitutionalism and the normative logic of two-level games // Journal of European Public Policy, vol. 22, issue 2, pp. 257-274.

Benz A. \& Papadopoulos Y. (2006) Actors, institutions and democratic governance: Comparing across levels // A. Benz \& Y. Papadopoulos (eds.) Governance and democracy. Comparing national, European and international experiences, London: Routledge, pp. 273-295.

Berger Helge, Dell'Ariccia Giovanni, and Obstfeld Maurice (2018) Revisiting the economic case for a fiscal union in the Euro area, Washington, DC: International Monetary Fund, February 20. URL: ttps://www.imf.org/en/Publications/Departmental-Papers-Policy-Papers/Issues/2018/02/20/Revisiting-theEconomic-Case-for-Fiscal-Union-in-the-Euro-Area-45611.

Berghahn V. and Young B. (2013) Reflections on Werner Bonefeld's 'Freedom and the strong state: On German ordoliberalism and the continuing importance of the ideas of Ordoliberalism to understand Germany's (contested) role in resolving the Euro Zone crisis // New Political Economy, vol. 18, no. 5, pp. 768-778.

Bermann G. A. (1994) Taking Subsidiarity Seriously: Federalism in the European Community and the United States // Columbia Law Review, vol. 94, no. 2, pp. 339-344.

Bozo F. (2009) Mitterrand, the End of the Cold War, and German Unification, New York, NY: Berghahn Books.

Broin Peadaro (2012) The Euro Crisis: The Fiscal Treaty - an Initial Analysis // Institute of International and European Affairs Working Paper, n 5.

Buiter W. H. (1999) Alice in Euroland //Journal of Common Market Studies, vol. 37, no 2, pp.181-209.

Buti M. and Franco D. (2005) Fiscal policy in economic and monetary union: theory, evidence and

Institutions, Cheltenham/UK and Northampton/MA/USA: Edward Elgar.

Cass D. Z. (1992) he Word That Saves Maastricht? The Principle of Subsidiarity and the Division of Powers within the European Community // Common Market Law Review, vol. 29, issue 6, pp. 1107-1136.

Chopin Th. (2016) Euro zone, legitimacy and democracy: how do we solve the European Democratic problem? // European issues, $\mathrm{n}^{\circ} 387$, 05th April. Available at: https://www.robert-schuman.eu/en/doc/questions-deurope/qe-387-en.pdf. 
Cisotta R. and Gallo D. (2014) The Portuguese Constitutional Court Case Law on Austerity Measures: A Reappraisal // LUISS Guido Carli / Department of Law Working paper, no. 4. URL: https://iris.luiss.it/retrieve/handle/11385/95388/1146/WPG_04-14_Cisotta_Gallo.pdf.

Constâncio V. (2017) Effectivenes of Monetary Union and the Capital Market Union // Speech at the EUROFI Conference, Malta, 6 April. URL: https://www.ecb.europa.eu/press/key/date/2017/html/sp170406_2.en.html.

Cooper Ian (2017) A Separate Parliament for the Eurozone? Differentiated Representation, Brexit, and the Quandary of Exclusion // Parliamentary Affairs, Volume 70, Issue 4, pp. 655-672. URL: https://doi.org/10.1093/pa/gsx022

Crum B. (2018) Parliamentary accountability in multilevel governance: what role for parliaments in post-crisis EU economic governance? //Journal of European Public Policy, vol.25, no 2, pp. 268-286.

Crum Ben (2017) Depoliticisation versus Accountability: What Role for Parliaments in Post-Crisis EU Economic Governance // Journal of European Public Policy, Volume 25, 2018 - Issue 2: SI: EU Socio-Economic Governance since the Crisis: The European Semester in Theory and Practice, pp. 268-286. URL: https://www.tandfonline.com/doi/abs/10.1080/13501763.2017.1363270.

Culpepper Pepper D, Hall Peter A. and Palier Bruno, eds. (2006) Changing France: The Politics that Markets Make. London: Palgrave.

Dabrowski M. (2015) Monetary union and fiscal integration // Conference: Toward a Genuine Economic and Monetary Union. At: Vienna. Volume: Workshop - Proceedings of the OeNB Workshops, No. 21. URL: https://www.researchgate.net/publication/299435966_Monetary_union_and_fiscal_integration.

Dabrowski, M. (2014) EU cohesion policy, horizontal partnership and the patterns of sub-national governance: Insights from Central and Eastern Europe // European Urban and Regional Studies, vol. 21, issue 4, pp. 364-383.

Dahl Robert (1999) Can International Organizations Be Democratic? A Skeptic's View // Ian Shapiro and Casiano Hacker-Cordon (eds.) Democracy's Edges, Cambridge, Cambridge University Press, pp. 19-36.

Darvas Zsolt and Leandro Alvaro (2015) The Limitations of Policy Coordination in the Euro Area under the European Semester // Bruegel Policy Contribution, Issue 2015/19, November. URL: http://bruegel.org/wpcontent/uploads/2015/11/pc_2015_194.pdf.

Dann Philipp (2004) Parlamente im Exekutiv föderalismus, Berlin: Springer.

De Bandt O. and Hartmann P. (2000) Systemic Risk: A Survey // ECB Working Paper, No. 35. URL: https://www.ecb.europa.eu/pub/pdf/scpwps/ecbwp035.pdf.

De Canio S., Dibble C., Amir-Atefi K. (2000) The Importance of Organizational Structure for The Adoption of Innovations // Management Science, vol. 46, No. 10, October, pp. 1285-1299.

De Witte Bruno, Beukers Thomas (2013) The Court of Justice approves the creation of the European Stability Mechanism outside the EU legal order: Pringle // Common Market Law Review, Volume 50, Issue 3, pp. 805-848.

De Witte B. (2011) The European Treaty Amendment for the Creation of a Financial Stability Mechanism // SIEPS European Policy Analysis, no 6, pp. 1-8. Available at: http://www.ose.be/files/midi_OSE/Dewitte_2011_6_sieps_paper.pdf.; Wessels W. (2016) The European Council, Palgrave Macmillan, pp. 187-209.

Decker F. (2000) Governance Beyond the Nation-state. Reflections on the Democratic Deficit of the European Union // Journal of European Public Policy, vol. 9, pp. 256-272.

Delanty G. (2007) Europeanization and Democracy: The Question of Cultural Identity // Democratic Dilemmas of Multilevel Governance: Legitimacy, Representation and Accountability in the European Union / Ed. by J. DeBardeleben and A. Hurrelmann, Basingstoke: Palgrave, pp. 77-93. 
Dolls Mathias, Fuest Clemens, Heinemann Friedrich,Peichl Andreas (2016) Reconciling Insurance with Market Discipline: A Blueprint for a European Fiscal Union // CESifo Working Paper, No. 5767. URL: https://pdfs.semanticscholar.org/16a1/2bd4aa501214ca5d660fdae945245e668376.pdf.

Dullien S. (2014) The Macroeconomic Stabilisation Impact of a European Basic Unemployment Insurance Scheme // Intereconomics, vol. 49 (4), pp. 189-193.

Dullien S. and Guérot U. (2012) The long shadow of ordoliberalism: Germany's approach to the euro crisis // ECFR, no 49, February. URL: https://www.ecfr.eu/page/-/ECFR49_GERMANY_BRIEF.pdf.

Easton D. (1965) A Systems Analysis of Political Life, New York: John Wiley.

Eichengreen Barry (2018) The Populist Temptation. Economic Grievance and Political Reaction in the Modern Era, Oxford: Oxford University Press.

Eichengreen Barry and Wyplosz Charles (2016) Minimal Conditions for the Survival of the Euro // Intereconomics, Volume 51, Issue 1, pp 24-28.

Ester Peter and Hubert Krieger (2008) Comparing labour mobility in Europe and the US: facts and pitfalls // Over.Werk. Tijdschrift van het Steunpunt WSE, 18(3-4): 94-98. URL: https://www.steunpuntwerk.be/system/files/overwerk_2008_3-4_12.pdf.

Evans M. and Augusto Zimmermann A. (2014) The Global Relevance of Subsidiarity: An Overview // Michelle Evans and Augusto Zimmermann (eds.) Global Perspectives on Subsidiarity, New York: Springer.

Fabbrini F. (2016) The European Court of Justice, the European Central Bank, and the Supremacy of EU Law // Maastricht Journal of European and Comparative Law, vol. 23, Issue 1, pp. 3-16. URL: https://papers.ssrn.com/sol3/papers.cfm?abstract_id=2714226\&rec=1\&srcabs=2574233\&alg=1\&pos=6.

Fabbrini F. (2015) From Executive Federalism to Executive Government: Current Problems and Future Prospects in the Governance of the EMU // F. Fabbrini, E.H. Ballin \& H. Somsen (eds.) What form of Government for the European Government and the Eurozone?, Bloomsbury: Hart Publishing, pp. 289-306.

Fabbrini F. (2014) The Euro-Crisis and the Courts: Judicial Review and the Political Process in Comparative Perspective // Berkeley Journal of International Law, vol. 32, issue 1, pp. 64-123. Available at: https://scholarship.law.berkeley.edu/cgi/viewcontent.cgi?article=1449\&context=bjil.

Fabbrini S. (2016) From consensus to domination: the intergovernmental union in a crisis situation // Journal of European Integration, vol. 38, issue 5, pp. 587-599.

Feld Lars and Osterloh Steffen (2013) Is a fiscal capacity really necessary to complete EMU? Paper presented at the workshop "How to build a genuine Economic and Monetary Union". URL: https://www.sachverstaendigenratwirtschaft.de/fileadmin/dateiablage/Sonstiges/Genshagen_Paper_-_Feld.pdf.

Ferrin M. and Kriesi H. (eds.) (2016) How Europeans View and Evaluate Democracy, Oxford: Oxford University Press.

Follesdal A., Hix S. (2006) Why There is a Democratic Deficit in the EU: A Response to Majone and Moravcsik//Journal of Common Market Studies, vol. 44, no 3, pp. 533-562. Available at: https://onlinelibrary.wiley.com/doi/pdf/10.1111/j.1468-5965.2006.00650.x.

Fossum J. E. (2016) Democracy and Legitimacy in the EU: Challenges and Options // Arena Working Paper, no 1 (February). URL: https://www.sv.uio.no/arena/english/research/publications/arena-working-papers/2016/wp-116.pdf.

Fuest Clemens and Peichl Andreas (2012) European Fiscal Union: What Is It? Does It work? And Are There Really 'No Alternatives'? // IZA Policy Paper, No. 39, pp. 1-10. URL: http://ftp.iza.org/pp39.pdf.

Furceri D and Zdzienicka A. (2015) The Euro area crisis: Need for a supranational fiscal risk sharing mechanism? // Open Economies Review, 26: pp. 683-710. 
Gesa P. and Vasilescu L.G. (2011) The Optimum Currency Area. Is the Euro an Optimum Currency Area? // MPRA Paper, no. 29656. Available at: https://mpra.ub.uni-muenchen.de/29656/1/MPRA_paper_29656.pdf.

Gilbert Niels, Hessel Jeroen and Verkaart Silvie (2013) Towards a Stable Monetary Union: What Role for Eurobonds? // De Nederlandsche Bank NV Working Paper, No. 3. URL: https://www.dnb.nl/en/binaries/Working\%20Paper\%20379_tcm47-291377.pdf.

Habermas Jürgen (2012) The Crisis of the European Union: A Response / tr. by Ciaran Cronin, Cambridge, UK: Polity Press.

Hayek F.A. (1978) Denationalization of Money - The Argument Refined, 2nd edn. London: The Institute of Economic Affairs.

Hayek F.A. (1976) Choice in Currency: a Way to Stop Inflation, London: The Institute of Economic Affairs. URL: https://iea.org.uk/wp-content/uploads/2016/07/upldbook409.pdf.

Hennessy A. (2014) Redesigning financial supervision in the European Union (2009-2013) // Journal of European Public Policy, Volume 21, Issue 2, pp. 151-168.

Héritier A. (1999) Policy-Making and Diversity in Europe: Escape from Deadlock, Cambridge University Press, Cambridge.

Hermann Ch. (2013) Crisis, Structural Reform and the Dismantling of the European Social Model(s) // Working Paper, Institute for International Political Economy Berlin, No. 26/2013. URL: http://hdl.handle.net/10419/83958.

Hix S. (2005). The Political System of the European Union, 2nd edn. Basingstoke: Palgrave.

Hlavac M. (2010) Less than a State, More than an International Organization: The Sui Generis Nature of the European Union (December 2). Available at SSRN: https://ssrn.com/abstract=1719308 or http://dx.doi.org/10.2139/ssrn.1719308.

Hodson D. (2010) Economic and monetary Union: an Experiment in New Mode of EU Policy-Making // Policy-Making in the European Union, Sixth edition, Oxford: Oxford University Press, pp. 157-180.

Högenauer A.L. and Howarth D. (2016) Unconventional Monetary Policies and the European Central Bank's Problematic Democratic Legitimacy // Journal of Public Law / ZeitschriftfüröffentlichesRecht, vol. 71, no. 2, pp. $425-448$.

Hollifield J.F. (2016) The Refugee 'Crisis' in Europe and the Policy Responses // Policy Brief (Washington, DC: Woodrow Wilson Center).

Hooghe L. and Marks G. (2009) A postfunctionalist theory of European integration: From permissive consensus to constraining dissensus // British Journal of Political Science, vol.39, issue 1, pp. 1-23. URL: https://www.unc.edu/ gwmarks/assets/doc/BJPS.postfunctionalism.2009.hooghe.marks.pdf.

Hooghe L., Marks G. (2001) Multi-Level Governance and European Integration, Lanham, Maryland: Rowman \& Little.

Horga I., Florian G. L. (2011) Multilevel Governance (MLG) and Subsidiary Principle in White Paper of MLG of the Committee of the Regions (COR) // Ioan Horga, Iordan Bărbulescu, Adrian Ivan, Mykolia Palinchak, Istvan Suli-Zakar (eds.) Regional and cohesion policy: insights into the role of the partnership principle in the new policy design, Oradea, pp.159-165. Available at: http://nbn-resolving.de/urn:nbn:de:0168-ssoar-331537.

Howse R., Nicolaidis K. (2001) Legitimacy and Global Governance: Why Constitutionalizing the WTO Is a Step Too Far // Porter R. B. et al. (eds.) Efficiency, Equity, and Legitimacy: The Multilateral Trading System at the Millenium, Washington, D.C: Brookings Institution Press, pp. 227-252.

In't Veld J., Larch M. and Vandeweyer M. (2012) Automatic Fiscal Stabilisers: What they are and what they do // European Economy Economic Papers, No. 452, European Commission, Directorate General Economic and Financial Affairs (DG ECFIN), Brussels, April. 
Ipsen H-P. (1993) Zur Exekutiv-Rechtssetzung in der Europaeischen Gemeinschaft //P. Badura and R. Scholz (eds.) Wege und Verfahren des Verfassungslebens. Festschrift fuer Peter Lerche. Muenchen: Beck.

Ipsen H-P. (1973) Über Supranationalität //Europäisches Gemeinschaftsrecht in Einzelstudien, Baden-Baden: Nomos, 1984, pp. 97-112.

Jabko N. (2006) Playing the Market: A Political Strategy for Uniting Europe, 1985-2005. Ithaca, NY: Cornell University Press.

Jachtenfuchs M. (2006). The European Union as a Polity (II) // Knut Erik Jørgensen, Mark A. Pollack, and Ben Rosamond (eds.), Handbook of European Union Politics, London: Sage, pp. 159-174

Jensen Th. (2009) The Democratic Deficit of the European Union // Living Reviews in Democracy, vol 1, pp.1-9. Available at: https://www.lrd.ethz.ch/index.php/lrd/article/view/lrd-2009-2/8.

Jones Erik (2004) European Monetary Union and the Problem of Macroeconomic Governance // Europe Today: National Politics, European Integration, and European Security / Ed. by Ronald Tiersk - Oxford: Rowman and Littlefield.

Kąkol M. (2017) Designing a fiscal union for the euro area // Ekonomia i Prawo. Ecomomics and Law, vol. 16, issue 4, pp. 413-432. URL:

https://www.researchgate.net/publication/322815877_Designing_a_fiscal_union_for_the_euro_areahttps://ww w.researchgate.net/publication/322815877_Designing_a_fiscal_union_for_the_euro_area.

Kenen, P. (1969) The theory of optimum currency areas: An Eclectic View // Monetary Problems of the International Economy / Ed. by R.A. Mundell and A.K. Swoboda -Chicago and London: The University of Chicago Press, pp. 41-60.

Kern A. (2017) The European Central Bank's supervisory powers: the need for enhanced macro-prudential supervision // Zurich Open Repository and Archive, pp. 349-350. URL: http://www.zora.uzh.ch/id/eprint/149183/1/Alexander_ECB_Legal_Conference_Eproceedings_201712.pdf.

Khan A. (2017) Central Bank legal frameworks in the aftermath of the global financial crisis // IMF working paper, no. 101. URL: https:/www.imf.org/en/Publications/WP/Issues/2017/05/01/Central-Bank-Legal-Frameworks-inthe-Aftermath-of-the-Global-Financial-Crisis-44858.

Kiiver P. (2011) The Early-Warning System for the Principle of Subsidiarity: The National Parliament as a Conseil d'État for Europe // European Law Review, vol. 36, no 1, pp. 98-108.

Kisgergely K., Szombat A. (2014) Banking Union through Hungarian Eyes - the MNB's Assessment of a Possible Close Cooperation //MNB Occasional Papers, 115, Budapest.

Kopric I. \& Kovac P., eds. (2017) European Administrative Space: Spreading Standards, Building Capacities, Bratislava: NISPAcee.

Koremenos B. and Snidal D. (2003) Moving Forward, One Step at a Time // International Organization, vol. 57, Issue 2, pp. $431-444$.

Koyama Yoji (2016) Chapter 8: Croatia's Challenges Regarding the Adoption of the Euro // The Eurozone Enlargement // Ed. by Yoji Koyama - Nova Science Publishers.

Kröger S. and Friedrich D. (eds.) (2012) The Challenge of Democratic Representation in the European Union, Basingstoke: Palgrave Macmillan.

Kunroo M.H. (2015) Theory of Optimum Currency Areas: A Literature Survey // Review of Market Integration, vol. 7, issue 2, pp. 87-116.

Kunstein T. and Wessels W. (2013) The New Governance of the Economic and Monetary Union: Adapted Institutions and Innovative Instruments // IAI Working Papers, no 1302. Available at: https://www.files.ethz.ch/isn/157646/iaiwp1302.pdf. 
Leibfried St. and Pierson P. (1995) Semisovereign Welfare States: Social Policy in a Multitiered Europe // St. Leibfried and P. Pierson (eds) European Social Policy: Between Fragmentation and Integration, Washington, DC: The Brookings Institution, pp. 43-77.

Lenaerts K. and Marlies D. (2002) New Models of Constitution-Making in Europe: The Quest for Legitimacy // Common Market Law Review, vol. 39, pp.1217-1253.

Leuffen D., Rittberger B. and Frank Schimmelfennig F. (2013) Differentiated Integration: Explaining Variation in the European Union, London: Palgrave Macmillan.

Lieberherr E. (2013) The Role of Throughput in the Input-Output Legitimacy Debate: Insights from Public and Private Governance Modes in the Swiss and English Water Sectors// Conference Paper. First International Conference on Public Policy. Panel 39: The New Policies of Privatization.

Lim C., Columba F., Costa A., Kongsamut P., Otani A., Saiyid M., WezelT., and Wu X. (2011) Macroprudential Policy: What Instruments and How to Use Them? Lessons from Country Experiences // IMF Working Paper, no. 238. URL: https://www.imf.org/external/pubs/ft/wp/2011/wp11238.pdf.

Lindberg L.N. and Scheingold S.A. (1970) Europe's Would-Be Polity: Patterns of Change in the European Community, Englewood Cliffs, N.J.: Prentice-Hall.

Lord C. (2017) An indirect legitimacy argument for a directly elected European parliament //European Journal of Political Research, vol. 56, issue 3, pp. 512-528.

Maatsch Aleksandra (2015) Empowered or Disempowered? The Role of National Parliaments during the Reform of European Economic Governance // MPIfG Discussion Paper, 15/10. URL: http://www.mpifg.de/pu/mpifg_dp/dp15-10.pdf.

Mair P. and Thomassen J. (2010) Political Representation and Government in the European Union //Journal of European Public Policy, vol. 17, no. 1, pp. 20-35.

Majone G. (2001) Nonmajoritarian Institutions and the Limits of Democratic Governance: A Political Transaction-Cost Approach // Journal of Institutional and Theoretical Economics (JITE) / Zeitschriftfür die gesamte Staatswissenschaft, vol. 157, no. 1, 18th International Seminar on the New Institutional Economics - The Proper Scope of Government, pp. 57-78.

Majone G. (1998) Europe’s Democratic Deficit // European Law Journal, vol. 4, no 1, pp. 5-28.

Majone G. (1997) From the positive to the regulatory state: Causes and consequences of changes in the mode of governance //Journal of Public Policy, vol. 17, no 2, pp. 139-167.

Majone, G. (1997) The Regulatory State and its Legitimacy Problems //Western European Politics, vol. 22, no. 1, pp.1-24.

Majone G. (1996) Regulating Europe, New York: Routledge.

March J. and Olsen J. (1998) The Institutional Dynamics of International Political Orders //International Organization, vol.52, issue 4, pp. 943-69.

Marks G. \& Hooghe L. (2004) Contrasting visions of multi-level governance // I. Bache \& M. Flinders (eds.) Multi-level governance, Oxford: Oxford University Press, pp. 15-30.

Marks G. (1992) Structural Policy in the European Community// A. Sbragia (ed.) Europolitics: Institutions and Policymaking in the 'New' European Community, Washington: Brookings Institution, pp. 191-224.

McNamara Kathleen R. (2005) Economic and Monetary Union: Innovations and Challenges for the Euro // PolicyMaking in the European Union, $5^{\text {th }}$ edition / Ed. by Helen Wallace, William Wallace and Mark Pollack Oxford: Oxford University Press, pp. 141-160. 
Mény Yves (2002) De la démocratie en Europe: Old Concepts and New Challenges // Journal of Common Market Studies, vol. 41, no. 1, pp. 1-13.

Méró Katalin \& Piroska Dora (2016) Banking Union and banking nationalism - Explaining opt-out choices of Hungary, Poland and the Czech Republic //Policy and Society, vol. 35, no 3.

Mitchel W. (2015) Eurozone Dystopia Groupthink and Denial on a Grand Scale, Cheltenham: Edward Elgar, pp. 94-110.

Mongelli F.P. (2008) European Economic and Monetary Integration, andthe Optimum Currency Area Theory // European Economy - Economic papers, No 302, February. Available at: http://ec.europa.eu/economy_finance/publications/pages/publication12081_en.pdf.

Moravcsik A. (2006) What Can We Learn from the Collapse of the European Constitutional Project? // Politische Vierteljahresschrift, vol. 47, pp. 219-241.

Moravcsik A. (2004) Is there a 'Democratic Deficit' in World Politics? A Framework for Analysis // Government and Opposition, vol.39, issue 2, pp. 336-363.

Moravcsik A. (2002) In Defence of the 'Democratic Deficit': Reassessing Legitimacy in the European Union // Journal of Common Market Studies, vol. 40, no 4, pp. 603-624.

Moravcsik A. (1998) The Choice for Europe, Ithaca: Cornell University Press.

Moravcsik A. (1993) Preferences and power in the European Community: a liberal intergovernmentalist approach // Journal of Common Market Studies, vol.31, issue 4, pp. 473-524.

Mundell, R. A. (1997) “Optimum Currency Areas”, extended version of a luncheon speech at Tel-Aviv University, available at: http://www.columbia.edu/ ram15/eOCATAviv4.html

Mundell, R. A. (1973) A Plan for a European currency // The Economics of Common Currencies / Ed. by H.G. Johnson and A.K. Swoboda - London: Allen and Unwin, p. 143-172.

Mundell, R.A. (1961) A Theory of Optimum Currency Areas // American Economic Review, vol. 51, no 4, pp. 657-665.

Musgrave R. \& Musgrave P. (1989) Public finance in theory and practice, $5^{\text {th }}$ edition, New York, McGraw-Hill.

Naert Frank (2017) EU governance and the European Fund for Strategic Investment // European Administrative Space: Spreading Standards, Building Capacities / Ed. by I. Kopric \& P. Kovac - Bratislava: NISPAcee, pp. 77-94. URL: https://biblio.ugent.be/publication/8523646/file/8525040.pdf.

Nielsen, J.H. (2015). In or out? Denmark during the Euro Crisis // Same, Same but Different: The Nordic EU Members during the Crisis, Stockholm: Swedish Institute for European Policy Studies (SIEPS), pp. 6-23.

Obstfeld M. (2013) Finance at center stage: Some lessons of the euro crisis // European Economy Economic Papers, No. 493, Brussels: European Commission.

Paun Ch. (2018) The euro and European monetary policy: a critical view // Doing Business in Europe. Economic Integration Processes, Policies and the Business Environment/ Ed. by A.N. Dima - Cham, Switzerland: Springer, pp. 125-148.

Pennesi F. (2016) The impossible constitutional reconciliation of the BVerfG and the ECJ in the OMT case. A legal analysis of the first preliminary referral of the BVerfG // Perspectives on Federalism, vol. 8, issue 3, pp. 1-21. URL: http://www.on-federalism.eu/index.php/articles/248-the-impossible-constitutional-reconciliation-of-thebverfg-and-the-ecj-in-the-omt-case-a-legal-analysis-of-the-first-preliminary-referral-of-the-bverfg.

Peters B. G. \& Pierre J. (2004) Multi-level Governance and Democracy: A Faustian Bargain? // I. Bache \& M. Flinders (eds.) Multi-level Governance, Oxford: Oxford University Press, pp. 75-89. 
Piattoni S. (2009) Multi-level Governance: a Historical and Conceptual Analysis // European integration, vol. 31, no 2, pp. $163-180$.

Pierson Paul and Leibfried Stephan (1995) The Dynamics of Social Policy Integration // Stephan Leibfried and Paul Pierson (eds.) European Social Policy: Between Fragmentation and Integration, Washington D.C.: The Brookings Institution, pp. 432-466.

Profant Tomas, Toporowski Patryk (2014) Potential for Cooperation: Polish and Czech Standpoints on the Banking Union // PISM Policy Paper, № 16 (99), https://www.pism.pl/files/?id_plik=18005.

Putnam R. (1988) Diplomacy and domestic politics: the logic of two-level games // International Organization, vol. 42, issue, 3, pp. 427-460.

Quaglia L. and Maes I. (2004) France and Italy's Policies on European Monetary Integration: A Comparison of 'Strong' and 'Weak' States // Comparative European Politics, vol. 2, issue 1, pp. 51-72.

Rockoff H. (2003) How Long Did It Take the United States to Become an Optimal Currency Area? // Monetary Unions: Theory, History, Public Choice / Ed. by F. H. Capie and G. E. Wood - London: Routledge, pp. 70-103.

Rodica E. (2012) The first and second Barre Plans // A Rereading of the Werner Report of 8 October 1970 in the light of the Pierre Werner family archives. Sanem: CVCE, 2012. Available at: https://www.cvce.eu/content/publication/2011/12/1/a27c0587-77ad-479e-a644cb56dbaf9c90/publishable_en.pdf.

Rodrik D. (2011) The Globalization Paradox. Democracy and the Future of the World Economy, New York and London: W.W. Norton.

Saccomanni F. (2015) The Report of the Five Presidents: A Missed Opportunity // Documenti IAI, no 15, 14 July. Available at: http://www.iai.it/sites/default/files/iai1514.pdf.

Scharpf F. W. (2015) After the Crash: A Perspective on Multilevel European Democracy // European law Journal, Vol. 1, Issue 3, May, pp. 384-405.

Scharpf F. W. (1999) Governing in Europe: Effective and Democratic?, Oxford: Oxford University Press.

Scharpf, F.W. (1998) Interdependence and Democratic Legitimation // Max Planck Institute for the Study of Societies // Working Paper, No. 2, Cologne. Available at: http://www.mpifg.de/pu/workpap/wp98-2/wp98-2.html.

Schmidt V. (2016) Reinterpreting the Rules "by Stealth" in Times of Crisis: The European Central Bank and the European Commission // West European Politics, vol. 39, no. 5, pp. 1032-1052. Available at: http://blogs.bu.edu/vschmidt/files/2016/09/Schmidt-WEP-reinterpreting-the-rules-by-stealth-final.pdf.

Schmidt V. (2010) Democracy and Legitimacy in the European Union Revisited. Input, Output and Throughput // KFG Working Paper, no. 21, 31 p. Available at: http://userpage.fuberlin.de/kfgeu/kfgwp/wpseries/WorkingPaperKFG_21.pdf.

Schmidt V. (2006) Democracy in Europe: The EU and National Polities, Oxford: Oxford University Press. O завершении периода «разрешительного консенсуса» см. также: Deutsch F. (2006) Legitimacy and Identity in the European Union: Empirical Findings from the Old Member States // Ireneusz Pawel Karolewski, Viktoria Kaina (eds.) European Identity. Theoretical Perspectives and Empirical Insights, Münster: LIT, 149-178.

Schmitter Ph. (2005) Ernst B. Haas and the legacy of neofunctionalism // Journal of European Public Policy, vol. 12, issue 2: The Disparity of European Integration: Revisiting Neofunctionalism in Honour of Ernst Haas, pp. $255-272$.

Schütze R. (2010) From Rome to Lisbon: 'Executive federalism' in the (new) European Union //Common Market Law Review, vol. 47, no 5, pp. 1385-1427. 
Schweiger Ch. (2016) Exploring the EU's Legitimacy Crisis: The Dark Heart of Europe, Cheltenham, UK, Northampton, MA, USA: Edward Elgar.

Scotto N. (2012) Chapter 11: How does the financial crisis affect the independence of the European Central Bank? The European Rescue of the European Union? The existential crisis of the European political project // Edoardo Chiti, Agustín José Menéndez and Pedro Gustavo Teixeira (eds.) ARENA Report No 3/12, RECON Report No 19. ARENA Centre for European Studies Oslo, pp. 347-390. Available at: http://www.reconproject.eu/main.php/RECONreport1912.pdf?fileitem=50487366.

Schelkle W. (2014) Fiscal integration by default // Beyond the Regulatory Polity? The European Integration of Core State Powers / Ed. by P. Genschel and M. Jachtenfuchs - Oxford, England: Oxford University Press, p. 105123.

Schneider J.D. (2015) Growth for Europe - is the Juncker Plan the Answer? // European Policy Centre Discussion Paper, March. URL: http://www.epc.eu/documents/uploads/pub_5420_growth_for_europe__is_the_juncker_plan_the_answer.pdf.

Schoenmaker D. (2013) An Integrated Financial Framework for the Banking Union: Don't Forget Macro-Prudential Supervision // EC Economic Papers, no. 495, April. URL: http://ec.europa.eu/economy_finance/publications/economic_paper/2013/pdf/ecp495_en.pdf.

Sims C. A. (2012) Gaps in the Institutional Structure of the Euro Area // Financial Stability Review / Banque de France, No. 16 (April).

Snell Jukka (2016) The Trilemma of European Economic and Monetary Integration, and its Consequences // European Law Journal, vol. 22, issue 2, pp. 157-179. Available at SSRN: https://ssrn.com/abstract=2772283 or http://dx.doi.org/10.1111/eulj.12165.

Spendzharova Aneta B. \& Bayram Ismail Emre (2016) Banking union through the back door? How European banking union affects Sweden and the Baltic States // West European Politics, vol.39, no 3, pp. 565-584.

Steeck W. and Schmitter P. (1991) From National Corporatism to Transnational Pluralism: Organized Interests in the Single European Market // Politics and Society, vol. 19, no 2, pp.133-164.

Stephenson P. (2013) Twenty years of multi-level governance: 'Where Does It Come From? What Is It? Where Is It Going? // Journal of European Public Policy, vol. 20, issue 6, pp. 817-837.

Stubb A. (1996) A Categorization of Differentiated Integration // Journal of Common Market Studies, vol. 34, issue 2, pp. 283-295.

Sweet Alec Stone and Thatcher Mark (2002) Theory and Practice of Delegation to Non-Majoritarian Institutions //West European Politic, vol. 25, no 1, pp. 1-22. Available at: https://pdfs.semanticscholar.org/6060/b3618b535f60b06353ce10c98870e8ed5842.pdf.

Szász A. (1999) The Werner Report. 1970 //The Road to European Monetary Union. London: Palgrave Macmillan, pp. 30-35.

Szombati A. (2017). Banking Union Through Hungarian Eyes - Assessment of a Possible Close Cooperation //Journal of Governance and Regulation, vol. 6, no 1, pp. 63-77. URL: http://dx.doi.org/10.22495/jgr_v6_i1_p6.

Tabellini G. (2003) Principles of policymaking in the European Union: an economic perspective // CESifo Economic Studies, Molume 49, шssue 1, 1 January pp. 75-102.

Tichy G. (1992) Theoretical and Empirical Considerations on the Dimension of an Optimum Integration Area in Europe // Aussenwirtschaft, vol. 47, issue 1, pp. 107-37.

Tsoukalis L. (2016) In Defense of Europe, Oxford: Oxford University Press. 
Vanheuverzwijn Pierre (2017) How the Commission fills in the blanks of the European Semester // Politique européenne, 2017/1 (No 55), pp. 8-35.

Van Kersbergen K. and Verbeek B. (2007) The Politics of International Norms: Subsidiarity and the Imperfect Competence Regime of the European Union // European Journal of International Relations, vol. 13, issue 2, pp. 217-238.

Verhelst S. (2013) Assessing the Single Supervisory Mechanism: Passing the Point of No Return for Europe's Banking Union, Brussels: Egmont Institute.

Vos H., Boucke T., Devos C. (2002) The conditio sine qua non of the added value of regions in the EU - upper-level representation as the fundamental precondition // Journal of European Integration, vol. 24, no 3, pp. 201 -218.

Wiegandt M.H. (1995) Germany's International Integration: The Rulings of the German Federal Constitutional Court on the Maastricht Treaty and the Out-of-Area Deployment of German Troops// American University International Law Review, vol. 10, no. 2, pp. 889-916. Available at: http://digitalcommons.wcl.american.edu/cgi/viewcontent.cgi?article=1438\&context=auilr.

Wolf M. (2014) The Shifts and the Shocks: What We've Learned - And Have Still to Learn - from the Financial Crisis, New York: Penguin.

Woolley J. (1994) Linking Political and Monetary Union: The Maastricht Agenda and German Domestic Politics // The Political Economy of EMU / Ed. by B. Eichengreen and J. Frieden - Boulder, Colorado: Westview Press, pp. 67-86.

Wymeersh E. (2015) Banking Union; Aspects of the Single Supervisory Mechanism and the Single Resolution Mechanism compared // ECGI Working Paper Series in Law, no. 290. URL: http://www.ecgi.global/sites/default/files/working_papers/documents/SSRN-id2599502.pdf.

Young B. (2014) German Ordoliberalism as Agenda Setter for the Euro Crisis: Myth Trumps Reality // Journal of Contemporary European Studies, vol. 22, no. 3, pp. 276-287.

Zilioli Ch. (2016) The Independence of the European Central Bank and Its New Banking Supervisory Competences //The Independence and Legitimacy in the Institutional System of the European Union / Ed. by D. Ritleng Oxford: Oxford University Press, pp. 125-179.

Zurn M. (2000) Democratic Governance beyond Democratic Governance Beyond the Nation-State: The EU and Other International Institutions // European Journal of International Relations, vol. 6 issue 2, pp. 183-221. 
Научное издание

Стрежнева Марина Вадимовна

Экономический и валютный союз в Европе: проблемы эффективности и легитимности

\author{
Монография
}

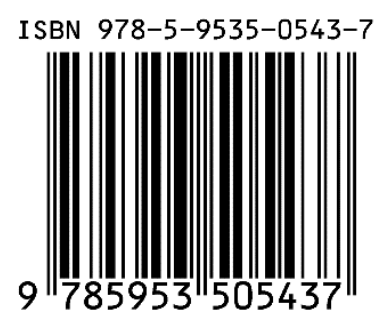

Подписано в печать 13.12.2018.

Формат 60×84/8. Печать офсетная.

Объем 19 п.л., 13,3 а.л. Тираж 250 экз. Заказ № 28/2018

Издательство ИМЭМО РАН

Адрес: 117997, Москва, Профсоюзная ул., 23 